\title{
Price Transmission within selected Agricultural Markets of Latin America
}

Dissertation submitted to the Faculty of Agricultural Sciences

to obtain the $\mathrm{Ph}$. D. degree

Georg-August-University Göttingen, Germany

By Karla Vanessa Hernández-Villafuerte

born in San José Costa Rica

Göttingen, February, 2012 
D7

1. Name of referee: Prof. Dr. Stephan von Cramon-Taubadel

2. Name of co-referee: Prof. Dr. José M. Gil

Date of dissertation: February $1^{\text {st }}, 2012$ 


\section{Abstract}

The agricultural sector plays a major role in Latin American economies, comprising up to 23 percent of GDP (e.g. Guatemala and Nicaragua). Of course, it is also very important to the labor market, the income of the poorest people and food security. The food crisis of 2008 has raised numerous questions about the impact of such variability on welfare and the economic sector which directly concerns the agricultural sector. Given the importance of the agricultural sector to the economies, if governments are to take adequate measures to ensure food security, they need to have a good understanding of the functioning of their markets. This implies, among others things, knowing the state of price transmission. While this is essential for many reasons, the most important is that price transmission determines the prices information available to agricultural producers, which is a prerequisite for good allocation of resources. Incomplete price transmission creates biased incentives to producers, which can lead to suboptimal decision-making and reduced agricultural productivity. Despite the importance of price transmission to agricultural markets in Latin America, there are only few articles which deal with this issue. This research helps fill this gap and provide policy makers better knowledge of the direct and indirect effect of their decisions.

This PhD thesis consists of six Chapters; Chapter 1 includes a general introduction and Chapter 2 presents an overview and discussion of the four papers included in the thesis, with all four exploring price transmission in selected Latin American markets.

Chapter 3 includes "Asymmetric Price Transmission and Structural Breaks in the Relationship between Costa Rican Markets of Livestock Cattle, Beef and Milk" exploring the vertical integration between these three markets. The analysis of the price transmission between joint products (relationship between markets relying upon a different production chain) is the main contribution of this document since it is nearly nonexistent in the cointegration literature.

Chapter 4 includes "Price Transmission in Latin American Maize and Rice Markets" evaluating price transmission from the international to the domestic markets with a focus on rice and maize markets. The main findings point out the existence of higher relationship with the international markets of Brazil and Chile (the South American countries included) than Central America countries.

Chapter 5 presents the paper "The Relationship between Spatial Integration and Geographical Distance in Brazil". The literature identifies geographic distance as a significant factor affecting the level of price transmission between markets. This paper explores explanations for this significant effect, analyzing the relationship between cointegration and of the influencing factors, likely correlated with distance. The results show that the influence of distance on integration is in part determined by the significant effect on price transmission.

Finally, Chapter 6, "Spatial Price Transmission of the Rice Market of Northeastern Brazil and the Variables which affect it", is an analysis of the relationship between prices of the poorest region of Brazil and its international and national trade partners. Moreover, the factors which have a significant 
impact on this relationship are determined. The focus is on rice since this plays a key role in the diets of the most food insecure people in northeast region. The results suggest that the presence of a main unloading port has a positive impact on the level of price transmission. Therefore, although the northeastern states are relatively isolated it could change rapidly since the ports of this region are experiencing a noteworthy development.

In general, the methodology used throughout this thesis is based in the cointegration framework used to identify the price transmission among markets. The analysis also accounts for asymmetric behavior and structural breaks. Additionally, an important contribution of this work to the spatial price transmission analysis deserves to be highlighted, the inclusion of a set of variables, apart from distance, which has not yet been used to explain integration relationships.

In summary, the papers focusing on rice show that the markets which are separated by long distances are less integrated than those which are closer to each other; however, there are other variables which also affect integration, such as access to a main port. Since these variables continue to evolve, integration will continually adjust. This development occurs not only in Brazil, but also in the rest of Latin America. Therefore, it is necessary to strengthen the assessments and monitoring of national and international prices, as well as the relationships between them. 


\section{Zusammenfassung}

Der Agrarsektor spielt eine wichtige Rolle in lateinamerikanischen Wirtschaftssystemen, er beinhaltet bis zu 23 Prozent des BIP (z.B. in Guatemala und Nicaragua). Natürlich ist er auch sehr wichtig für den Arbeitsmarkt, das Einkommen der ärmsten Menschen und die Ernährungssicherung. Die Nahrungsmittelkrise von 2008 hat zahlreiche Fragen über die Auswirkungen solcher Schwankungen auf das Wohlergehen und die Wirtschaft, die den Agrarsektor unmittelbar betrifft, aufgeworfen. Wenn Regierungen geeignete Maßnahmen ergreifen wollen, um Ernährungssicherheit zu gewährleisten, müssen sie ein sehr gutes Verständnis für das Funktionieren ihrer Märkte, angesichts der Bedeutung des Agrarsektors für die Wirtschaft, haben. Dies setzt unter anderem das Wissen über den Stand der Preisweitergabe voraus. Dies ist in vielerlei Hinsicht wichtig, der bedeutendste Grund ist jedoch, dass die Preisweitergabe die Preisinformationen, welche den landwirtschaftlichen Erzeugern zur Verfügung stehen, bestimmt, was eine Voraussetzung für eine gute Verwendung der Ressourcen ist. Unvollständige Preisweitergabe schafft voreingenommene Anreize für Erzeuger, was zu suboptimaler Entscheidungsfindung und reduzierter Produktivität in der Landwirtschaft führen kann. Trotz der Bedeutung der Preisweitergabe auf Agrarmärkten in Lateinamerika, gibt es nur wenige Artikel, die sich mit diesem Thema befassen. Diese Forschungarbeit hilft, diese Lücke zu füllen und den politischen Entscheidungsträgern verbessertes Wissen der direkten und indirekten Auswirkungen ihrer Entscheidungen zukommen zu lassen.

Diese Dissertation besteht aus sechs Kapiteln. In Kapitel 1 wird eine allgemeine Einführung gegeben. Die Arbeit beinhaltet vier Papiere welche die Preisweitergabe in ausgewählten lateinamerikanischen Märkten erforschen. In Kapitel 2 wird ein Überblick sowie eine Diskussion über die vier Arbeiten gegeben.

In Kapitel 3 wird die asymmetrische Preisweitergabe sowie Strukturbrüche in der Beziehung zwischen Costa Ricanischen Märkten für Nutztierwissenschaften Rinder, Rindfleisch und Milch (, Asymmetric Price Transmission and Structural Breaks in the Relationship between Costa Rican Markets of Livestock Cattle, Beef and Milk") behandelt, worin die vertikale Integration zwischen diesen drei Märkten erforscht wird. Die Analyse der Preisweitergabe zwischen verbundenen Produkten (Beziehung zwischen Märkten stützt sich auf eine andere Produktionskette) ist der wichtigste Beitrag dieses Dokuments, da es in der Kointegrationsliteratur fast nicht vorhanden ist.

Kapitel 4 enthält Preisweitergabe in Lateinamerikas Mais und Reis Märkten ("Price Transmission in Latin American Maize and Rice Markets"), welches die Preisweitergabe von internationalen zu heimischen Märkten, mit Schwerpunkt auf Reis und Mais Märkte, auswertet. Die wichtigsten Ergebnisse weisen auf die Existenz einer höheren Beziehung zu internationalen Märkten von Brasilien und Chile (die südamerikanischen Länder eingeschlossen) als zentralamerikanischen Ländern hin.

Kapitel 5 stellt die Beziehung zwischen räumlicher Integration und geografischer Entfernung in Brasilien ("The Relationship between Spatial Integration and Geographical Distance in Brazil") dar. 
Die Literatur bezeichnet geographische Distanz als bedeutenden Faktor, welcher die Ebene der Preisweitergabe zwischen den Märkten beeinflusst. Diese Arbeit untersucht Erklärungen für diesen signifikanten Effekt, indem sie die Beziehung zwischen Kointegration und den Einflussfaktoren analysiert, die wahrscheinlich mit Entfernung in Beziehung stehen. Die Ergebnisse zeigen, dass der Einfluss der Entfernung auf die Integration teilweise durch die signifikante Wirkung auf die Preisweitergabe bestimmt wird.

Schließlich beinhaltet Kapitel 6 die räumliche Preisweitergabe des Reismarktes im Nordosten Brasiliens und den Variablen, die diese beeinflussen ("Spatial Price Transmission of the Rice Market of Northeastern Brazil and the Variables which affect it"). Hierbei handelt es sich um eine Analyse der Beziehung zwischen Preisen der ärmsten Region Brasiliens und ihrer internationalen und nationalen Handelspartnern. Darüber hinaus werden die Faktoren, die einen signifikanten Einfluss auf diese Beziehung haben, ermittelt. Der Schwerpunkt liegt auf Reis, da dieser in der Ernährung der meisten von Ernährungsunsicherheit betroffenen Menschen in der Nordost-Region eine wichtige Rolle spielt. Die Ergebnisse legen nahe, dass das Vorhandensein eines Haupt-Entladehafens einen positiven Einfluss auf die Höhe der Preisweitergabe hat. Deshalb könnte sich das, obwohl die nordöstlichen Staaten relativ isoliert sind, schnell ändern, da die Häfen dieser Region eine bemerkenswerte Entwicklung erfahren.

Im Allgemeinen basiert die Methodik, die in dieser Arbeit verwendet wurde, auf dem Rahmen der Kointegration. Dieser wurde benutzt, um die Preisweitergabe innerhalb von Märkten zu identifizieren. Die Analyse berücksichtigt auch asymmetrisches Verhalten und strukturelle Brüche. Ein wichtiger Beitrag dieser Arbeit im Bereich der räumlichen Preisweitergabe ist darüber hinaus die Einbeziehung einer Reihe von Variablen, abgesehen von Entfernung, die noch nicht verwendet wurden, um Integrationsbeziehungen zu erklären.

Zusammenfassend zeigen die Arbeiten, welche ihren Schwerpunkt auf Reis legen, dass die Märkte, die durch große Entfernungen voneinander getrennt sind, weniger integriert sind als jene, die näher beieinander sind; aber es gibt noch andere Variablen, die auch Auswirkungen auf die Integration haben, wie beispielsweise der Zugang zu einem Haupthafen. Da sich diese Variablen ständig weiterentwickeln, wird sich die Integration kontinuierlich anpassen. Diese Entwicklung tritt nicht nur in Brasilien, sondern auch im Rest von Lateinamerika auf. Daher ist es notwendig, die Einschätzung und die Überwachung von nationalen und internationalen Preisen, sowie die Beziehungen zwischen ihnen zu stärken. 


\section{Acknowledgements}

There is a long list of persons who I must express my profound gratitude, in the following some of them are gratefully acknowledged. However, I am aware of the fact that there are many more and these words cannot express the gratitude and respect I feel for all of those.

First, I would like to express my sincere gratitude to my advisor Prof. Stephan von Cramon-Tabaudel for his suggestions and support which have made my $\mathrm{PhD}$ experience productive and stimulating, without his immense knowledge this $\mathrm{PhD}$ thesis would not have been written. Moreover, I cannot forget to express appreciation to Prof. Bernhard Brümmer and Prof. José M. Gil; I have extremely benefited from their expertise and experience. I would also like to take this opportunity to thank the organization which has provided financial support to make this work possible: the German Academic Exchange Service (DAAD).

I would like to thank my friends and colleges Rico Ihle and Sergio Rene Araujo-Enciso. In particular, thanks to Rico for giving me time when he did not have any, and Sergio, thank-you for your ideas, support and our friendly and pleasant work environment.

I am also indebted to the ECLAC team of Chile, especially Prof. Adrián Rodríguez. Through our working together I had the opportunity to enrich my knowledge and experience. Likewise, ECLAC is the source of most of the data used in this research.

I would also like to express my thanks to two people from the University of Costa Rica which are very important to me: first my dear mentor and ultimate exemplar Prof. Juan Rafael Vargas, secondly, my friend and work partner Prof. Yanira Xirinachs-Salazar who gave me the idea to apply for the scholarship which eventually brought me to Germany.

It is also a pleasure to mention my mother, my companion and support, where would I be without her? Thanks as well to my Dad and two brothers, Henry and Christian, who are ever essential in my life. My grandmother should be acknowledged here as well, "Mami Jacinta", and my Aunt Flor, who gave me their support and prayers and look at me now next to God. Gracias familia esto no es mio es nuestro.

A special thanks to my Fabian who has been my inspiration and support, and the best reason to partake in new and exciting plans.

Last but most importantly, my loved and adored God who has given me his patience, strength and support: he is the only one who knows what adventure lie ahead. 


\section{Contents}

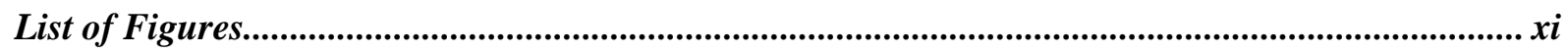

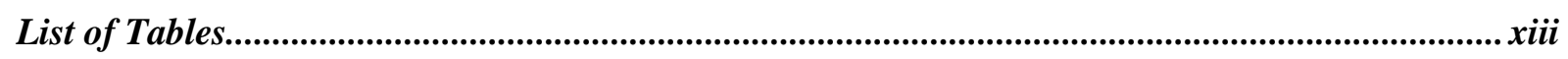

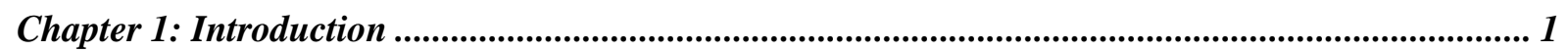

Chapter 2: Overview and Discussion of the Research Papers........................................................5

2.1. Costa Rican Markets of Livestock Cattle, Beef and Milk ..................................................... 5

2.2. Latin American Maize and Rice Markets ............................................................................. 8

2.3. Spatial Integration and Geographical Distance in Brazil ................................................... 12

2.4. Spatial Price Transmission of the Rice Market of Northeastern Brazil and Variables which

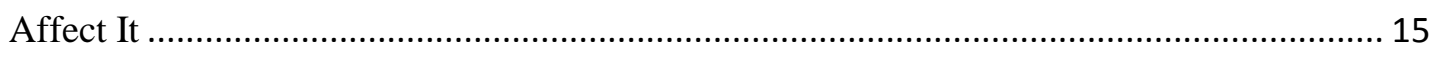

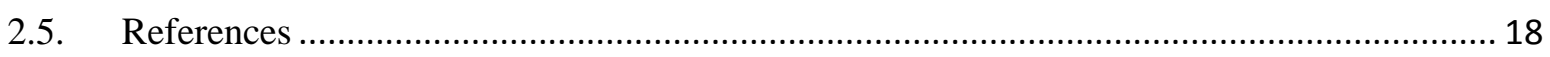

Chapter 3: Asymmetric Price Transmission and Structural Breaks in the Relationship between Costa Rican Markets of Livestock Cattle, Beef and Milk ............................................................. 21

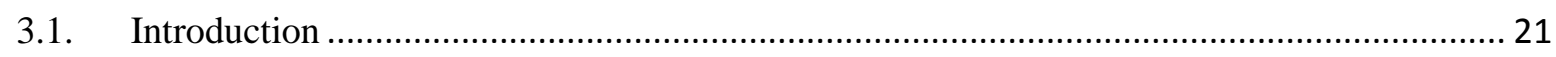

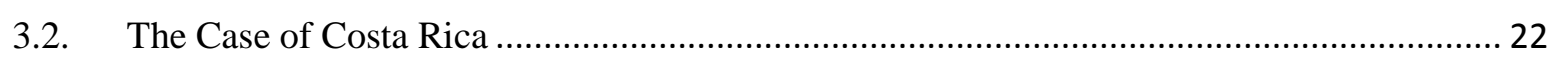

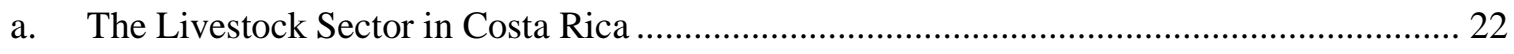

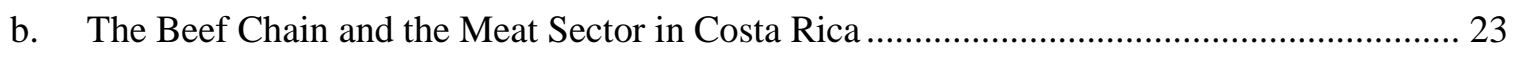

c. The Milk Cattle Chain and Milk Sector in Costa Rica............................................................ 24

d. Important Changes in the Milk and Beef Markets .............................................................. 25

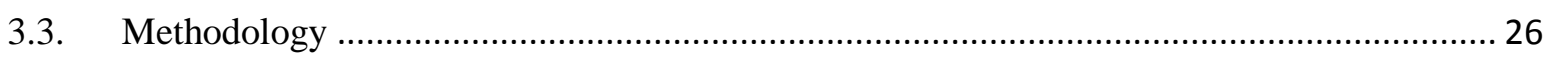

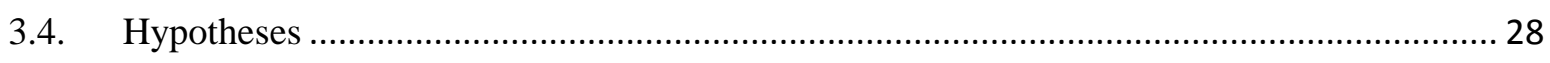

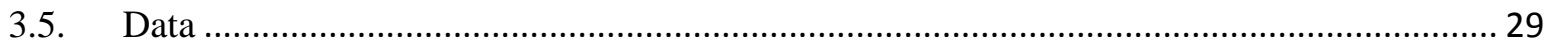

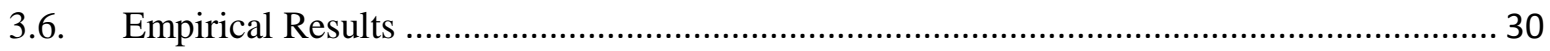

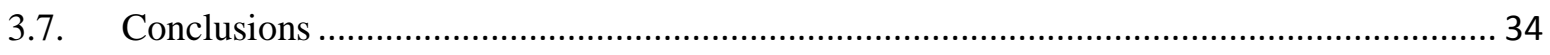

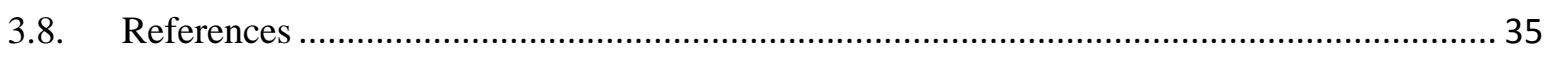

Annex 3.1: Stability Analysis of the Long Run Equation: Cusum and Cusum Square..................... 37 


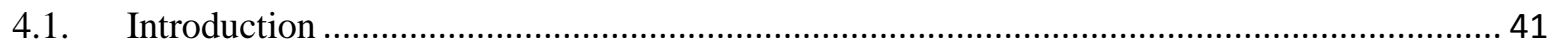

4.2. Price Transmission and Asymmetric Price Transmission ..................................................... 43

4.3. The Latin American Agricultural Sector: Rice and Maize ................................................ 46

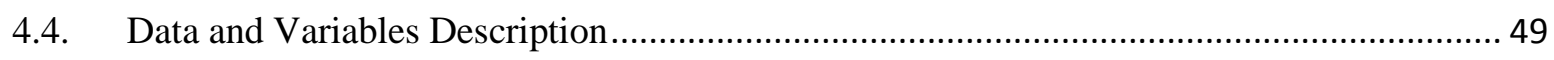

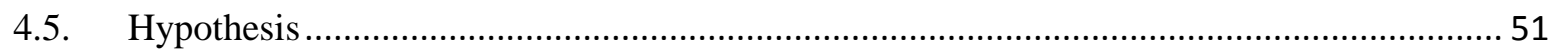

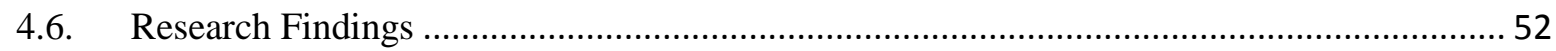

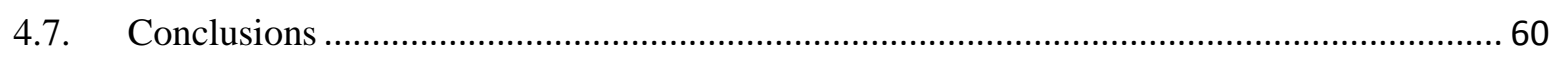

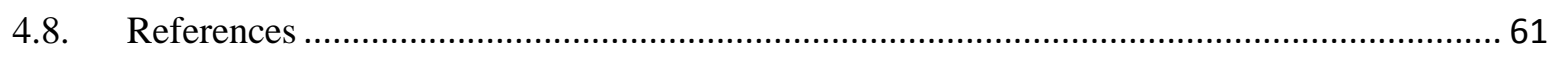

Annex 4.1: Number of Observations and Time Span in each Price Relationship ............................ 64

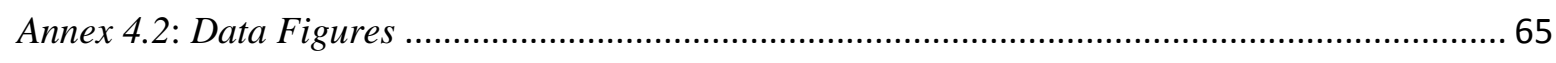

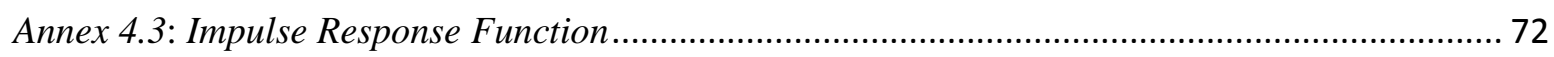

Chapter 5: The Relationship between Spatial Integration and Geographical Distance in Brazil .... 77

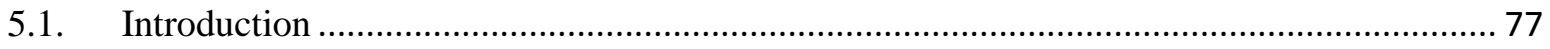

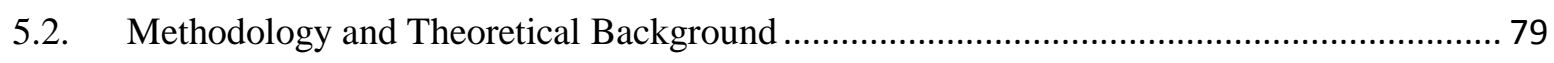

a. Cointegration-based Measurement of Market Integration.................................................. 79

b. Quantifying the Relationship between Market Integration and Distance: Bias and Incidence

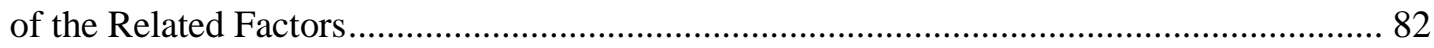

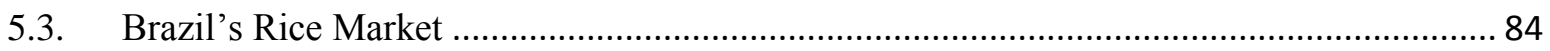

a. Central Markets: Highest Consuming and Producing States.............................................. 84

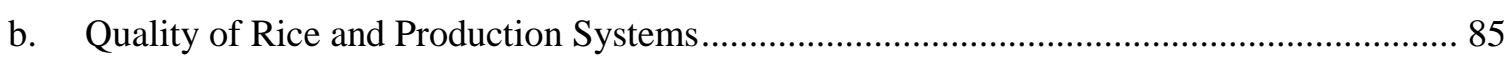

c. Gross Domestic Product GDP and GDP per capita............................................................ 87

d. Access to International Markets: Port Export Points.............................................................. 89

5.4. Economic and Political Reforms: 1990 - 2006.................................................................. 91

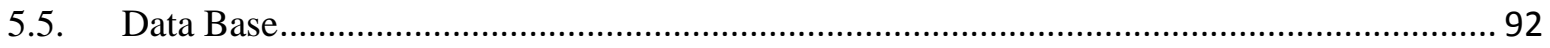

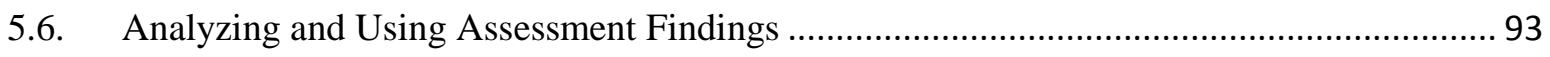

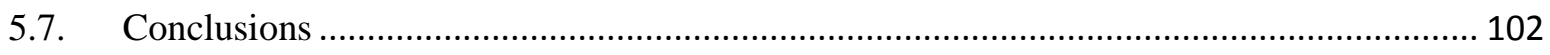

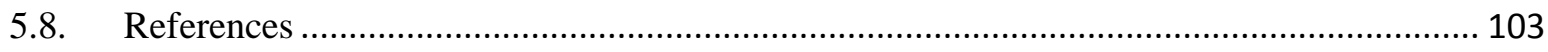

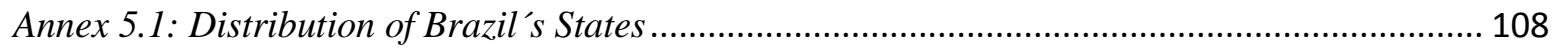

Annex 5.2: Characteristics of the Price Series ............................................................................ 109

Chapter 6: Spatial Price Transmission of the Rice Market of Northeastern Brazil and the Variables

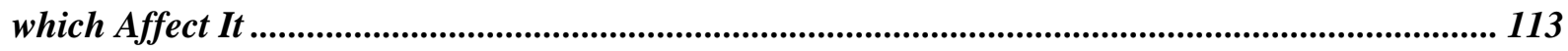

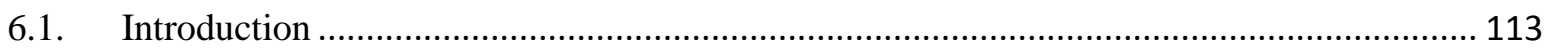


6.2. The Economic Situation of the Northeastern Region of Brazil ........................................ 115

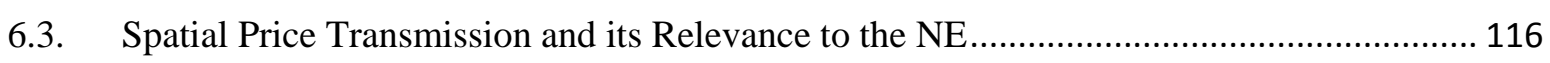

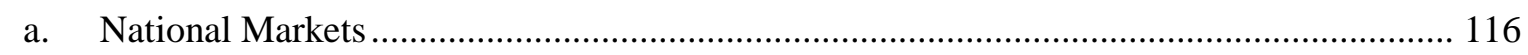

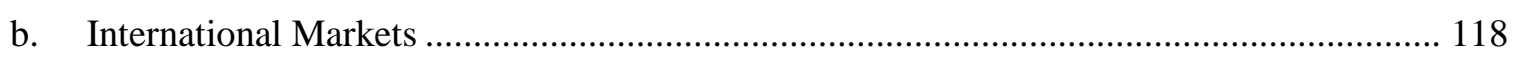

c. Economic Reforms and other Relevant Events between 1990 and 2006 ............................ 119

d. Possible Determinants of the Integration Measures in Brazil ............................................ 121

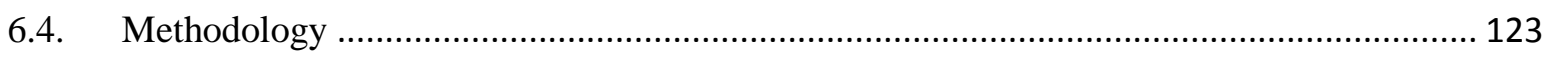

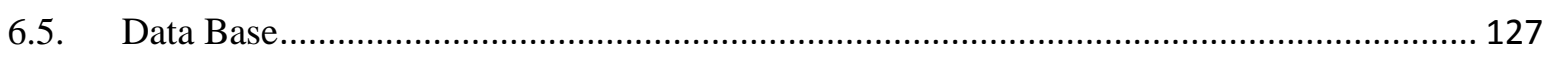

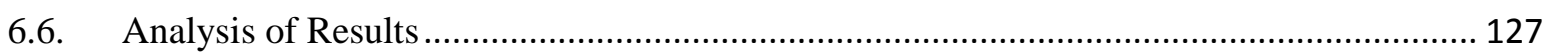

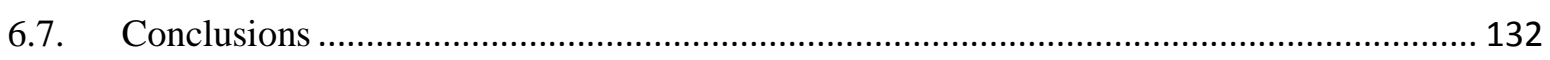

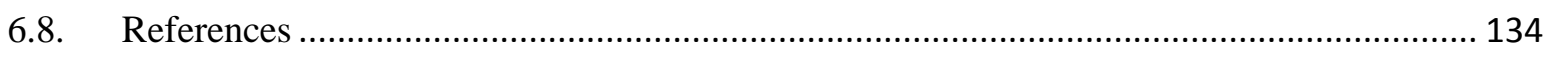

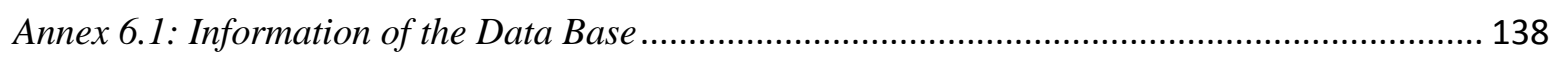

Annex 6.2: Results when One Structural Break is allowed for .................................................. 139 


\section{List of Figures}

Chapter 3: Asymmetric Price Transmission and Structural Breaks in the Relationship between Costa Rican Markets of Livestock Cattle, Beef and Milk

Figure 3. 1 Added Value of Livestock 23

Figure 3. 2 Consumption of the Principal Meat Products 24

Figure 3. 3 International Prices of the Feed Products............................................................................. 25

Figure 3. 4 Log of Prices Beef, Milk and Livestock Markets, 1998/1- 2008/4 ................................... 26

Figure 3. 5 Joint Products: Relationships between the Livestock, Beef and Milk Markets in Costa Rica 29

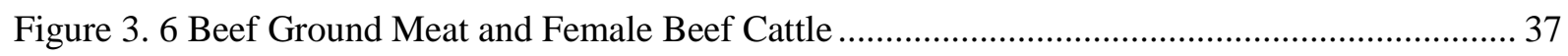

Figure 3. 7 Beef Ground Meat and Milk Powder …….......................................................................... 37

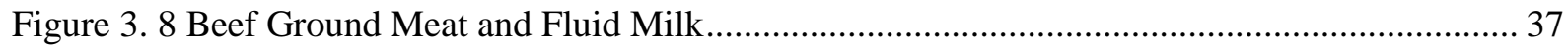

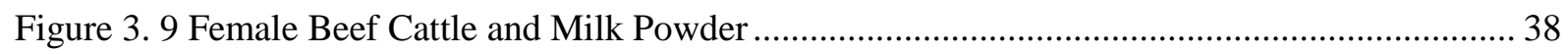

Figure 3. 10 Female Beef Cattle and Fluid Milk ……....................................................................... 38

Figure 3. 11 Beef Ground Meat, Female Beef Cattle and Fluid Milk …................................................ 38

Figure 3. 12 Beef Ground Meat, Female Beef Cattle and Milk Powder ............................................... 39

\section{Chapter 4: Price Transmission in Latin American Maize and Rice Markets}

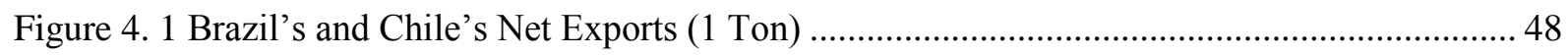

Figure 4. 2 Central American Countries' Net Exports ...................................................................... 49

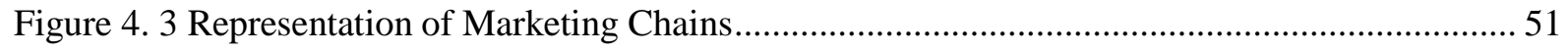

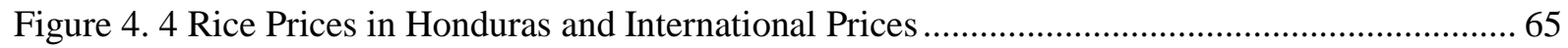

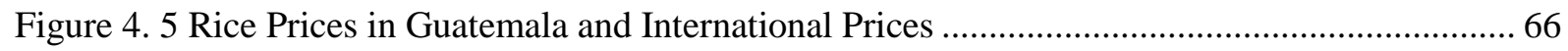

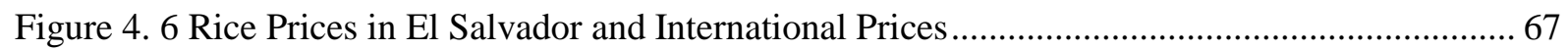

Figure 4. 7 Rice Prices in Nicaragua and International Prices ............................................................. 67

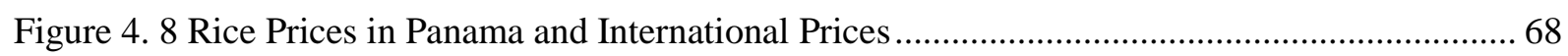

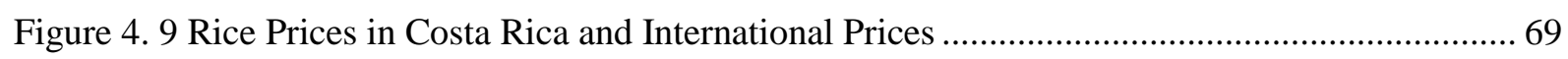

Figure 4. 10 Rice Prices in Brazil and International Prices .............................................................. 70

Figure 4. 11 Rice Prices in Chile and International Prices .................................................................. 71

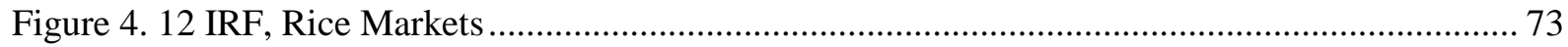




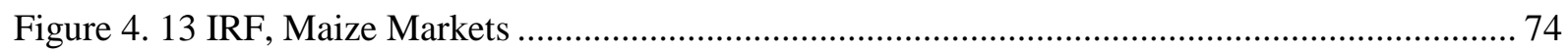

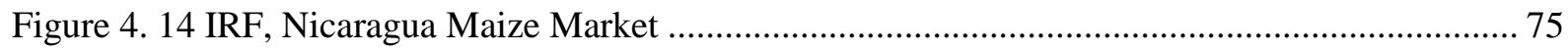

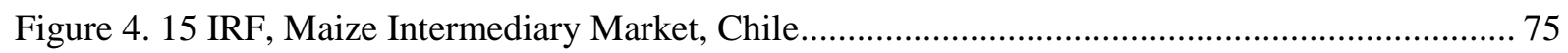

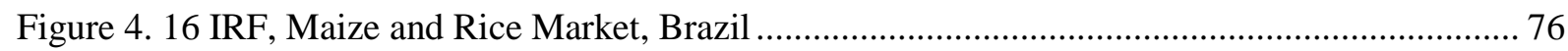

Chapter 5: The Relationship between Spatial Integration and Geographical Distance in Brazil

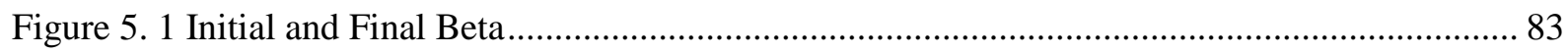

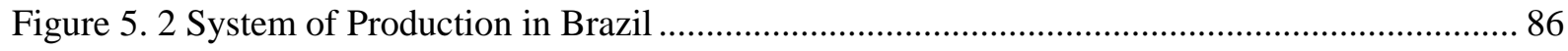

Figure 5. 3 Brazilian States By GDP and GDP Per-Capita 2008 (R\$) .............................................. 88

Figure 5. 4 Proportion of Brazil's Total Rice Import which Enter By Maritime Route. Quarter Data

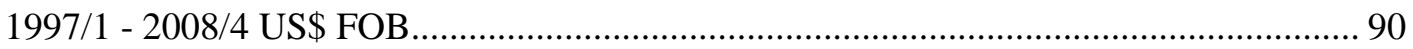

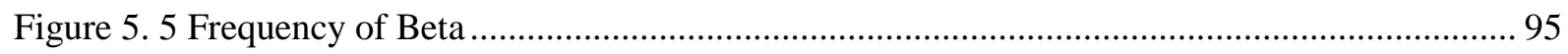

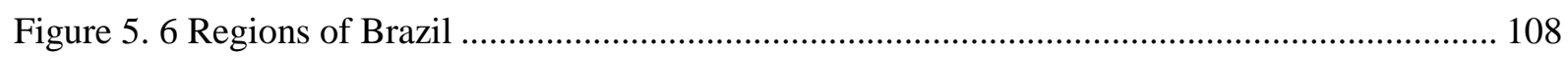

Figure 5. 7 Rice Prices of the Northern Region of Brazil (Dollars per Kilo).1990/2 - 2006/1 .......... 110

Figure 5. 8 Rice Prices of the Northeastern Region of Brazil (Dollars per Kilo).1990/2 - 2006/1 .... 110

Figure 5. 9 Rice Prices of the Middle-Western Region of Brazil (Dollars per Kilo).1990/2 - 2006/1

Figure 5. 10 Rice Prices of the Southeast and South Regions of Brazil (Dollars per Kilo).1990/22006/1

\section{Chapter 6: Spatial Price Transmission of the Rice Market of Northeastern Brazil and Variables which Affect It}

Figure 6. 1 North East Imports Coming from Argentina and Uruguay According to the Route of Access (US\$ FOB)

Figure 6. 2 Cointegrated Relationships with Structural Breaks: Elasticity of Cointegration (B) and Speed of Adjustment (A)

Figure 6. 3 International Rice Prices (US Dollars per Ton). 1993/1 - 2006/1 


\section{List of Tables}

Chapter 3: Asymmetric Price Transmission and Structural Breaks in the Relationship between Costa Rican Markets of Livestock Cattle, Beef and Milk

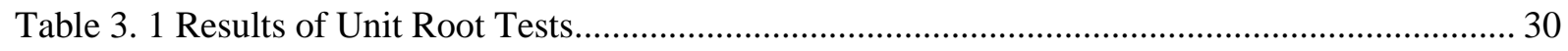

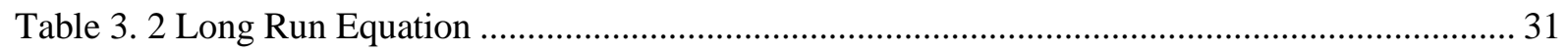

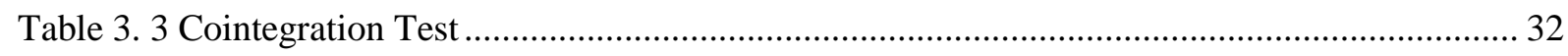

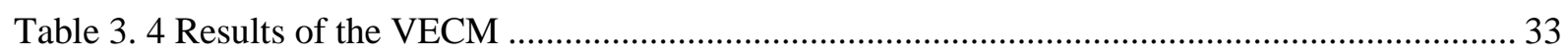

\section{Chapter 4: Price Transmission in Latin American Maize and Rice Markets}

Table 4. 1 Share of Rice and Maize in Total Energy Consumption (kcal/per-capita/day) ................... 43

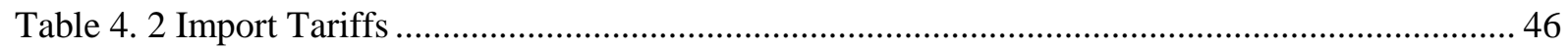

Table 4. 3 Unit Root and Cointegration Tests Results ….................................................................... 54

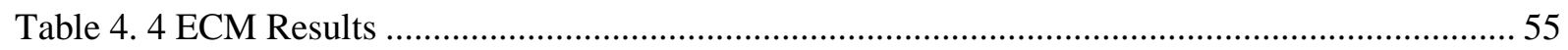

Table 4. 5 Number of Observations and Time Span of each Price Relationship .................................. 64

\section{Chapter 5: The Relationship between Spatial Integration and Geographical Distance in Brazil}

Table 5. 1 Description of the Indicators Used to Evaluate the Related Variables.................................. 93

Table 5. 2 Period of Significant Structural Breaks (Number of Relationships .................................... 95

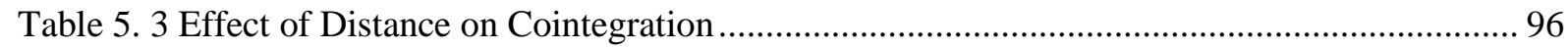

Table 5. 4 Effect of Having a Central Market on the Relationship ..................................................... 97

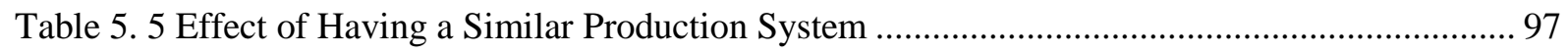

Table 5. 6 Effect of the Gross Domestic Product GDP and GDP Per-Capita ....................................... 98

Table 5. 7 Access to International Markets: Export Points With Ports ............................................... 100

Table 5. 8 Regression Including the Four Related Variables .......................................................... 101

Table 5. 9 States and Periods Included in the Investigation ............................................................ 109

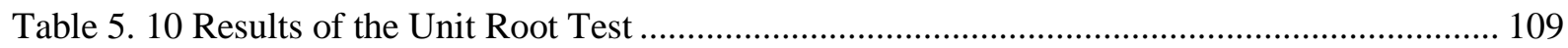

Chapter 6: Spatial Price Transmission of the Rice Market of Northeastern Brazil and the Variables which Affect It

Table 6. 1 Relative Participation of Rice in the Yearly Household Per-Capita Food Expenses by Income and Region. 
Table 6. 2 Relative Participation of Total Caloric Consumption Determined by Household Food Acquisition (2008-2009): Rice and the Most Important Food Groups

Table 6. 3 Independent Variables

Table 6. 4 Break Points

Table 6. 5 Domestic Market Relationships: Effect of the Independent Variables on the Elasticity of Cointegration ( $\beta$ ): OLS Model

Table 6. 6 Domestic Market Relationships: Effect of the Independent Variables on the Speed of the Adjustment ( $\alpha$ ): OLS Model.

Table 6. 7 Effect of the Independent Variables on the Probability of being Cointegrated with International Markets: Probit Model. 132

Table 6. 8 States and Periods Included in the Investigation. 138

Table 6. 9 Number of Cointegration Relationships and Year of Break Point Per Market. 139

Table 6. 10 North East Cointegrated Relationships with Structural Breaks: Elasticity of Cointegration (B) and Speed of Adjustment (A). 140 


\section{Chapter 1}

\section{Introduction}

This $\mathrm{PhD}$ thesis consists of four papers which explore Price Transmission in selected Latin American markets. The first, explains in Chapter 3, presents an analysis of the milk and beef markets of Costa Rica, the second in Chapter 4 explores integration between a group of selected Latin American market and the principal international markets. The last two papers (Chapters 5 and 6) can be grouped into one category related to Brazil's rice market. In addition, Chapter 3 deals with vertical price transmission while the remaining three analyze spatial price transmission.

The first paper "Asymmetric Price Transmission and Structural Breaks in the Relationship between Costa Rican Markets of Livestock Cattle, Beef and Milk" explores the vertical integration between these three markets. However, rather than only considering vertical price transmission as an indicator of the relationship between two markets of the same production chain of production, it investigates another kind of relationship which has yet to be deeply investigated: joint products. These are products which are produced with a single production process using common inputs, but do not correspond to the same chain (for example the butter and cheese). A special case here is the beef and milk markets of Costa Rica. Even if these products usually correspond to disconnected chains, in Costa Rica farms make use of cattle to produce both meat and milk. The cointegration framework is applied in order to indentify the price transmission among these markets, while taking asymmetric behavior and structural breaks into account. Price transmission between each market pair was found. The adjustment in response to deviations from the long run equilibrium is done by the cattle price in the milk vs. cattle relationship, by beef meat price in the cattle vs. beef meat, and by beef meat price in the milk vs. beef meat relationship.

The paper "Price Transmission in Latin American Maize and Rice Markets", which is explained in Chapter 3, written in cooperation with the Agricultural Development Unit of the Economic Commission for Latin-American and the Caribbean (ECLAC), which is headquartered in Chile. In view of the important increment on prices in 2008 and its effect on food security of the poorest countries in the world, the goal of the research is to support policy makers in the decision making process of regulation of the rice and maize markets. The paper analyzed price transmission from the international market to the domestic ones with a focus on rice and maize markets. The countries studied are El Salvador, Honduras, Panama, Guatemala, Nicaragua and Costa Rica in Central America (CA) and Chile and Brazil in South America. Price transmission between international FOB prices and domestic 
intermediary and producer prices is evaluated. Cointegration methods are applied to determine if price transmission exists and, when it exists, how strong it is. Next, error correction models are used to estimate the speed of adjustment to deviations from the long-run relationship between the domestic and international markets. Impulse response functions are finally computed to better observe the response of domestic prices to shocks of the international prices. Evidence of price transmission is found to be particularly complete for Brazil and Chile. It also appears stronger between international and intermediary markets than between the international and producer markets. Finally, evidence shows better transmission among rice than maize markets.

The third paper, "The Relationship between Spatial Integration and Geographical Distance in Brazil", explores alternative explanations for the significant effects of geographical distance on integration, which, as pointed out in the literature, is usually measured as the long run elasticity of cointegration. Here it is shown that other variables related to distance have an effect on market integration. Spatial integration coefficients are calculated for each Brazilian rice market pair, for which a cointegration framework is applied. To account for multiple economic changes during the period under investigation, the presence of multiple structural breaks in the long run equation is allowed for. The estimation of the relationship between the integration measure and geographical distance is completed using a simple OLS regression. Finally, in order to account for the effects of the addition of related variables, the omitted variables bias is looked at. Results show that there is a weak, negative and significant relationship between distance and the cointegration elasticity. Finally, three out of four variables cause, with their omission, a bias ranging from 10 to $25 \%$ of the real distance value coefficient. This shows that the distance effect on integration is explained not only by increments in transfer costs, but also by the existence of other variables which affect integration and of which values are more dissimilar between remote markets than closer ones.

Finally, the last paper entitled "Spatial Price Transmission of the Rice Market of Northeastern Brazil and the Variables which affect it" is the second document focused on Brazil's rice market. The northeast of Brazil is home to more than 9 million people living in extreme poverty. Rice plays a key role in the diets of many of these individuals. Hence, rice prices influence poverty and hunger in the region, and understanding rice market integration and the transmission of rice price signals is an important ingredient in any effort to design policies to reduce poverty and hunger. The aim this research is to determine the grade of integration of the NE with both national and international markets and examine which variables influence it. Using the Johansen methodology, spatial integration of the poorest region of Brazil, the NE, with the remaining regions and the main international markets is analyzed. In order to account for changes of the Brazilian economy during the period of investigation, the presence of structural breaks is allowed for. The effect of distance, access to an important unloading port and the GDP is estimated using OLS and probit regressions. It is found that the NE states are relatively isolated from both the rest of Brazil and within the Brazilian region. The OLS analysis shows an elasticity of cointegration which presents a strong positive relationship with the presence of an important unloading port. Moreover, distance has a negative effect on integration. 
Additionally, it is more probable to find cointegration for relationships with Argentina and with access to a main port.

In summary, the papers which focus on rice show that the markets which are separated by a long distance are less integrated than those which are closer to each other; however, there are other variables which have also an effect on integration, such as access to a main port. Since these variables continue to evolve, integration will continue to change in the near future. This development occurs not only in Brazil, but also in the rest of Latin-America. Therefore, it is necessary to strengthen the assessments and monitoring of national and international prices, as well as the relationships between them. 


\section{Chapter 2}

\section{Overview and Discussion of the Research Papers}

\subsection{Costa Rican Markets of Livestock Cattle, Beef and Milk}

\section{Overview}

In this section we overview and discuss the study on price transmission between Costa Rican Markets of Livestock Cattle, Beef and Milk which was elaborated on during the period of 2008-2009. A previous version of this document was published by the Journal of Agricultural Science and Technology (ISSN 1939-1250) (Hernández, 2010). For the research we would like to thank the cooperation of the University of Costa Rica as they facilitated the access to the data base and some specific market information.

Traditionally, price transmission research splits the analysis into spatial and vertical relationships. The present study's contribution to the existing literature is to be focused on a third and not commonly explored option: joint products. This refers to the relationship of two or more products produced with a single production process using common inputs, for example, butter and cheese. The difference between our approach and the literature on milk and beef meat markets is that, although these two products are produced in disconnected chains in most countries and thus analyzed as non-integrated markets, in Costa Rica a quarter of the farms produce both beef meat and milk (Holmann et al., 2007). Hence, we consider milk and beef meat as joint products. These farms are known as double intention farms and keep $22 \%$ of the total cattle in Costa Rica, which is the common input used to produce both milk and beef meat.

In addition, beef and milk markets require a detailed analysis since they are essential components in the diet of the Costa Rican. For instance, in average the Costa Rican people drink around 200 liter of milk per year (Quirós, 2006) and in 85\% of households all the members eat beef meat (CORFOGA, 2001).

Engle and Granger's (1987) and Johansen's (1995) methodologies are employed to determine the existence of integration between the markets. Additionally, in order to take important events occurring during the period of analysis and affecting the milk and beef markets into consideration, structural breaks are allow for. The results point to evidence of a significant relationship between ground meat (beef) and milk markets, including both fluid milk and powder. This supports the hypothesis that these two markets are related as joint products. However, only weak evidence of cointegration between the 
milk sector and livestock markets was found, although, as we said above, the common input linking the markets should be the cattle used to produce milk and beef meat.

In the second part of the analysis the Error Correction Model (ECM) was estimated. Albeit the weak evidence for cointegration, by using the ECM it was possible to find a significant adjustment of milk and livestock prices which indicates the relevance of the short run structure.

Additionally, the results also support the idea that the cooperative with the larger share of the Costa Rican milk market, Dos Pinos, has a high influence on this market which is transmitted to the livestock and beef markets. First, this influence is especially obvious in the shape of milk powder and fluid milk prices which increments are a direct response of the Dos Pinos's adjustments. Secondly, the adjustments of both fluid milk and powder to deviations of the long run equilibrium are smaller or not significant in most of the relationships.

Finally, in view that it is easier to send a cow to slaughter than to increase the herd to produce milk and due to the high concentration of the slaughter sector by a few firms only, asymmetry price transmission (APT) was expected. However, there is no evidence of APT in any of the relationships.

\section{Discussion}

In summary, the main outcome of this research is the existence of a relationship between meat and milk markets where the leader is the milk market. The latter is explained by the main role of Dos Pinos in the milk market. Although beef and milk are two staple products in Costa Rica, this document corresponds to one of few analyses of these markets. Moreover, to our knowledge, this is the first attempt to look into the integration among them. Accordingly, in light of our results and what has been learned over the course of this thesis and in order to continue with the investigation a further research agenda is recommended.

First, a price transmission analysis between the national prices of milk/meat and the international prices of the raw materials of livestock is recommended. This is associated with the results obtained from including the structural breaks into the long run relationship. The fact that most of the breaks happened during the period whereby the international prices of cattle feeding stuffs increased considerably means that the price variations of raw material have not only an effect on milk and beef prices, through increased production costs, but also lead to a change in integration. Therefore, not only an integration analysis between national and international markets is highly recommended, but also the application of a smooth transition analysis (Teräsvirta, 1998; Teräsvirta, 2004), using international prices as a transition variable, in order to capture the effects of the raw material prices on the relationship among our joint products. Nevertheless, checking the structural break results should be the step before incorporating the international prices into the analysis since the structural break methodologies learnt throughout the doctoral thesis are more robust than the one that is utilized in this first research. 
Second, the results reveal differences regarding the integration of the fluid and milk powder markets, especially concerning the relationship with the cattle market. One possible explanation lies in the characteristics of demand associated with each type of milk; for instance, milk powder is a staple product for children during the nursing stage, for which there are few possibilities for substitution. Hence, research conducted in different countries has found that the price elasticity of powdered milk is considerably smaller (in absolute value) than fluid milk, which is in most cases highly inelastic (e.g. Charalambos, 1999; Mckenzie \& Nieuwoudt, 1985; Song \& Summer, 1999). Another factor might be the importance in Costa Rica of each type, seeing as $62 \%$ of milk is sold as fluid milk while only $8 \%$ corresponds to powdered milk (Camara Nacional de Productores de Leche, 2010). However, the literature does not always present a concrete clarification; for Costa Rica there is no analysis of the features associated with each market type of milk and the effect of alterations of these markets on nutrition, let alone integration with other markets. Therefore, further research should include a price transmission analysis of both fluid and milk powder markets, as well as an identification of their most relevant characteristics.

In the process of performing the analysis we confronted some restrictions which limited the scope of the research. In the first place, throughout Costa Rica 19 livestock auctions operate with a wide range of prices. Although the Ministry of Agriculture has started to collect these prices, at the moment of the research the collection depended on the auctions owners' reports, which in many cases were sporadic and not completely reliable. Therefore, we estimated the cointegration equation using country-wide average data. However, seeing that there are spatial conglomerates of farms, these are not the real prices faced by farmers. For instance, dairy production is mainly made in the Huetar North and Central Regions with temperatures ranging from $18^{\circ} \mathrm{C}$ to $24^{\circ} \mathrm{C}$, while the warm Chorotega Region (between $24^{\circ} \mathrm{C}$ to $30^{\circ} \mathrm{C}$ ) is focused on beef meat and double intention production (Alfaro et al., 2007; Hidalgo, 2004). At the time of the research, plans for improvements in the data recollection were discussed within the Ministry. For that reason, a future investigation should incorporate more up-to-date information.

Furthermore, another limitation of this study is that, as was mentioned before, the milk price series reflects Dos Pinos's price policy. This is primarily due to the main role of Dos Pinos in the milk market, but also to the fact that prices are collected in the industry which are the formal distribution channels. Nevertheless, $36 \%$ of the milk production corresponds to producers which are not members of any cooperative and use informal distribution channels to sell milk. Many of these producers correspond to double intention farms, which, as was mentioned before, are those farms which produce both milk and beef meat. Therefore, the double intention farms, which connect our joint markets (beef meat and milk), could have a higher effect on the informal market than on the formal ones. For that reason, the analysis of informal prices should give a better idea of the integration mechanisms between markets. These informal prices behavior could be close to those of Dos Pinos, given that it plays a main role in the market, thus the results of the investigation would likely be the same; however, this cannot be proved since these prices are not collected and there is no approximation. 
Finally, another interesting follow-up work could also be the application of the threshold model rather than the asymmetry analysis. Although the research does not show significant asymmetry in the short run adjustments, for double intention farms it is much easier to decrease the number of cows, by selling them for slaughter, than to increase the cattle to produce milk. Therefore, the adjustment to the equilibrium should be faster/slower in response to a decrease/increase in the milk price or an increase/decrease in the beef meat price. Nevertheless, the decision of whether to sell or to buy cows is accompanied by a number of costs, as there are the costs of finding high quality cattle, transport costs, etc. For that reason, the expected gains of increasing milk production or selling the cattle to produce beef meat must be higher than the related costs. The threshold model, which states that the adjustment to the equilibrium will occur only once deviations are higher than the transaction costs (Balke \& Fomby, 1997), is a suitable methodology to explain this behavior.

\subsection{Latin American Maize and Rice Markets}

\section{Overview}

In response to the rises of commodity prices in 2007-2008 and the decreases that followed, the Division of Production, Productivity and Management of the Economic Commission for Latin America and the Caribbean (ECLAC), headquartered in Chile, with financial support from the French Cooperation and the Swedish Cooperation, has developed a project focused on the topic of price transmission of Latin America markets. This research arose from collaboration with the ECLAC in the framework of this project. The paper included in this document corresponds to the summary in the English language of the original paper published in Spanish by the ECLAC in its series of documents “Productive Development” (Dutoit, Hernández et al., 2010).

The purpose of this paper is threefold. Firstly, the presences of price transmission among the principal international markets and a group of selected Latin America markets are analyzed. Two types of relations are analyzed; on the one hand between international prices and domestic agricultural producer prices and, on the other hand, between international prices and domestic intermediary prices. With this aim, the cointegration frameworks suggested by Engle and Granger (1987) and Johansen (1995) is applied. Secondly, the speed at which the national markets response to shocks in the related international markets is examined. For this purpose, the short run adjustment, using the Error Correction Model (ECM), was estimated and the impulse response functions (IRF), which represent the response of the national price to a shock in the international price, were also displayed. Finally, whether the response to shocks is asymmetric is also determined, meaning the difference in the speed of adjustment when the shock is positive than when is negative. To this end, the ECM modified to allow for asymmetry (Granger \& Lee, 1989; von Cramon-Taubadel, 1998) was also estimated. Nevertheless, even if these were the three principal objectives of the research, the final goal was to provide the tools needed for Latin American policy makers to take appropriate actions in order to guarantee food security in this region. With this in mind and in order to facilitate an understanding of 
results, the methodological section of this paper includes a rough overview of the basis of price transmission theory.

Two markets were analyzed: rice and yellow maize. The Latin American rice markets which show cointegration with the international prices and fulfill the times series requirements for estimating the cointegration framework were Brazil, Costa Rica, Honduras, El Salvador and Nicaragua. One unexpected finding of this study is that although the largest amount of Central America's rice imports comes from the USA and not from Asian markets, there is a significant integration among Central America (CA) and Thailand prices. There are two likely explanations for this: in the first place, the connection among Thai and USA prices since there is a significant relationship between the latter and the CA markets with the sole exception of El Salvador. However, it is important to mention that even if the connection could be between the USA and El Salvador`s producer prices, it cannot be proven since this variable is not available for this country. In second place, in three CA countries there is market intervention, either from the government as in the Costa Rican case, or by means of sorts of cartels between producers and processors, as in the case of Honduras and Nicaragua, either the government or the other economic players take the Thai market into consideration to set the rice prices.

For its part, Brazil's results correspond to expectations since it is integrated with Argentina and Uruguay but not with Thailand. In addition, Brazil's elasticity of cointegration is close to one in the four relationships analyzed.

In the case of maize, the national markets integrated with the international ones were Brazil, Chile, Costa Rica and Panamá. The last is the only producer price analyzed in the maize case and differentiates itself from other markets by the destination of the product. Although yellow maize is usually led to feed animals; in Panamá it is destined for the human consumption. In addition, this market shows a small elasticity of cointegration which can be associated with the high level of organization among producers and the government protection which is reflected in the level of import tariffs (around 18\%).

In the South American maize markets integration occurs with the USA and Argentina, displaying an inelastic long run relationship. Although Brazil is a highly competitive market, where the producers are highly organized, in comparison with Chile that has a monopoly on the industry (principal enterprise AGROSUPER) and the producers have practically no level of organization, the results are not very different.

Regarding the speed of adjustment, although the ECM indicated that the rice markets have a slow speed back to the equilibrium, the IRFs, which take the lag structure of the equations into account, reveal that in most of the cases the new equilibrium is reached before eight months. The IRFs show that four of the six analyzed relationships achieve the equilibrium before ten months. Likewise, the maize market exhibits few evidence of asymmetry in the adjustment. There are indications of 
asymmetric behavior only in the intermediary rice market in two relationships: Nicaragua vs. Thailand and Brazil vs. Argentina.

\section{Discussion}

There are marked differences between the Latin-American countries which makes it difficult to establish recommendations which are applicable for the entire sector. However, one thing is clear: Central American markets are less integrated with the international market than South American markets. In this regard, CA prices are defined less by the market interaction and more by agreement between the associations of producers and industrialists or, in the case of Costa Rica, by government decree. On the contrary, in South America the prices are more defined by market interactions. Therefore, from the policy making point of view these results suggest that the application of protection measures and pricing policies prevent the spread of high volatility to sensitive markets in the region, maize and rice. However, when the producers do not need to compete through efficiency and quality, because they have a safe and stable income, they might be tempted to turn to low profitable but secure crops instead of competitive export crops. In any case, the decision corresponds to the interests and objectives of each country.

Nevertheless, this analysis opens the door to a list of new research opportunities which can continue to improve policy makers' decisions. With this aim and as a starting point, the following paragraphs give a list of research items. Firstly, it is only analyzed one price per country which corresponds to the average price of the states for which the information is available. However, the price transmission from the international markets to the domestic ones could be different within the country, as we shall see below in the case of Brazil. The characteristics and evolution of each regional market is in many cases dissimilar, for example, the production of maize in Chile is concentrated in the central region and in Brazil the policies to protect the producers and consumers are implemented in different ways by each regional government. These regional differences are particularly relevant if we consider that there are more sensitive regions in terms of food security; for example, the level of poverty in Managua, the capital of Nicaragua, is totally different than in the rural Atlantic region. Therefore, a more detailed analysis should be made in those countries where the data availability permits regional assessments. We have started this point with an examination of the biggest country of the sample, Brazil, the results of which are reported hereinafter.

Secondly, the inter-regional integration of prices is also a relevant topic of analysis. In this respect, Conforti (2004) found that the price transmission is stronger within the country than with the international markets. Normally, the central markets, usually located in urban areas, are the leaders determining the price movements within the country. This, combined with the striking discrepancies between the rural and urban areas in Latin-America (Estado de la Nación, 2011), make us think that not only the international but also the national price volatility can affect food security, especially for the poorest and most vulnerable people. In this regard, a first approach to this issue for the Brazilian case is presented in this thesis. 
Additionally, the CA countries have lower integration which is related with the high market protection. Although this decreases vulnerability to variations in international prices also results in welfare loss. The producers do not benefit of the favorable condition in international markets. Moreover, there are lower incentives to increase productivity and efficiency since it is not necessary produce competitive export crops. Therefore, the consumer's welfare is affected by lower quality products and the fact that there is not access product with lower prices and/or better quality which could be reached from international markets. This lost of welfare could be a topic for future research.

The last point goes hand in hand with other idea: the net benefit ratio of the households related to variations in price of rice and/or maize. This is the difference between the importance of the product for consumers or producers. Regarding to this, Minot (2010), points out that maize account for $6 \%$ of expenditures and $5 \%$ of income in Ghana which is translated in a small negative net benefit ratio. Moreover, Minot also mention that even if rice is less importance than maize in Ghana, the adverse impact of a given price increase in rice is higher because it has a more negative net benefit ratio. Minot analyses the results of price transmission incorporating the net benefit ratio, and thus recognizing effects on welfare for both producers and consumers. With this in mind, in order to be able to increase the household welfare in each country is central to take the differences among countries in the net benefit ratio into consideration. Furthermore, the most vulnerable group of population in terms of food security could have a different net benefit ratio than the one for the whole country. Therefore, a further research should also include the identification of the most vulnerable groups and the estimation of the related net benefit ratio.

Another subject of further consideration should be the price transmission of white maize markets. In this current paper, the type of maize analyzed was yellow maize; the decision was taken in response to the availability of information, which allows the inclusion of a higher number of markets. However, in CA, with the exception of Panamá, the type of maize which is considered a staple food product is the yellow type. Moreover, according to our results the only maize market with weak integration was Panamá, which uses yellow maize mainly for human consumption. These two facts suggest that integration could also be determined by whether the maize is destined for human or animal consumption.

Next, the analysis of the markets which did not fulfill the time series cointegration requirements remains pending. For instance, Guatemala, where $40 \%$ of the daily energy intake comes from maize, could not be incorporated. The application of the Ravallion (1986) model, which permits the short and long run analysis of stationary series, is recommended.

As it is usual in time series analysis, the principal limitation of this research was the lack of data. Despite having prices for Bolivia, Ecuador and Peru, the series could not be included since the length and continuity of the information was not adequate at the time of the research. Moreover, as mentioned above, white maize prices were also not sufficient. Furthermore, the time frames of the 
price series were different in some markets, thus weakening the possibilities of comparison. Lastly, the lack of information prevented the analysis between the producer and intermediary markets.

Finally, since there are several levels of market concentration among Latin-America industry, one final proposal is the analysis of the effect of market concentration on integration. For instance, this is a central topic in the case of countries such as Nicaragua (rice) and Guatemala (maize) where there are monopolies at the commercial levels, while in other countries, such as El Salvador (rice), there is concentration but to a lesser extent. However, once again, data availability limits the possibilities. Nevertheless, although they are not the more robust indicators, methodologies such as the Lerner Index (Lerner, 1934) and the reciprocal of the number of companies are suggested since they are not very demanding of data and can be easily collected. Therefore, in order to estimate a market concentration indicator than could be used for explaining integration with international markets, the recommendation is to start with the elaboration of a database that includes data on the number of companies and the prices offered by the principal participants in the industry.

\subsection{Spatial Integration and Geographical Distance in Brazil}

\section{Overview}

This paper might be seen as a continuance of the paper discussed in Section 2.2. In that paper the analysis was a general overview of eight Latin-America countries. However, the need to further explore each market in a separate way was clear at the end, and this paper is the answer to that need. The decision to begin with Brazil is due to two factors. First, only in this case the data was available for every state within the country; furthermore, the data was also available not only for rice, but also for maize and soybeans. Secondly, Brazil has been experiencing a huge development with regard to trade amounts and economic indicators. However, the expansion has been unequal between the regions, and hence a closer look at the integration framework could provide some answers to this question.

The original idea was to implement cointegration to analyze price transmission in the three markets mentioned. Although the results were enlightening, the differences of the integration behavior among the states led us to explore the variables which cause this. The literature overview pointed out distance as the principal variable. Therefore, the second version of this document included an analysis of the effect of distance on integration measures. Nevertheless, in a country with profound and significant differences between states, the idea that distance was the unique variable which affects integration did not satisfy our interests. For that reason, further literature research covering a larger number of approaches outside of the price transmission analysis was carried out. As a result, new plausible variables from procedures, such as the gravity model and analysis of market liberalization, were incorporated. With this aim, the first attempts included a selected group of variables which could potentially explain integration, using first OLS Regression and then Principal Component Regression 
(Jolliffe, 2002; Mevik \& Wehrens, 2007). The latter is a method for combating multicollinearity and results in estimations and predictions which are better than ordinary least squares (Ramzan \& Inayat Khan, 2010). At this time, a subgroup of the analyzed variables turned out to be clearly significant determinants of integration, such as the GDP per-capita and the proximity to a main port. Additionally, clear geographic patterns were found in most of these variables, meaning similar values between closer markets. Hence, it is observed that these variables have an effect on integration, but at the same time are related to the distance. In order to confirm such findings, the present document was created with the main objective of investigating the influence of geographical distance on integration measures while taking the bias caused by the omission of variables which influence integration into consideration and showing higher divergence between remote markets than closer ones.

One of the three commodities mentioned before rice was selected as an example. The selection was made in accordance with three criteria: first, the importance of the staple product for Brazil; second, the amount of data available, which in the case of rice covers the whole of Brazil; and, third, that the most relevant characteristics of the market also have geographical patterns. After the selection, the research plans were rewritten for the case of the rice market following a more intuitive methodology. The aim of the change in the methodology was to derive a more policy orientated tool to capture the attention of the policy makers. Therefore, the estimation of the relationship between the integration measure and geographical distance was made using OLS regression, and, in order to account for the effects of the addition of related variables, the Omitted Variables Bias was implemented.

Apart from distance, four variables with a potential effect on integration were selected: the share of the market in terms of consumption and production, the quality of rice, the GDP/GDP per-capita and the accessibility to a main port. Regarding the first one, the results show that those relationships which involve a central market have a faster adjustment to the equilibrium and a higher level of integration. However, this variable does not have a relationship with the distance, and then even if it is relevant for determining the integration is not a variable which influences the significant relationship among the distance and the elasticity of cointegration. The second variable, quality of rice, was approximated using the system of production as a variable, since in Brazil rice is produced by irrigated systems or upland systems which produce rice of differing quality. As expected, those relationships with the same system of production are more integrated. In addition, the omission of this variable causes a bias in the distance coefficient. Concerning the GDP per-capita, in the cases for which both markets have a large GDP per-capita integration is stronger while it is weaker when one market has a large GDP perpita and the other market a small one. Likewise, this variable also affects the distance coefficient. Finally, the results of the last variable indicate that the presence of a main port has an effect only when this port is located in the leader market. What this says is that the leader markets, which are mainly producing states, take advantage of the port's proximity to send products to the Brazilian states along the coast. Once again, the omission of this variable produces a bias in the distance coefficient. 


\section{Discussion}

The bottom line of the study is that even though the geographical distance between markets affects integration, this effect can be partially seen as a reflection of the effect of other variables which are more dissimilar between separate markets than closer ones. Additionally, Brazil has experienced important changes and improvements in the variables which were found to be significant, such as port infrastructure and the level of GDP per-capita, which will finally result in alterations of integration relationships. Therefore, the conclusion of this research points to the importance of broadening the analysis and searching for explanations of the levels of integration between markets. Otherwise, it would not be possible to predict the development of the relationships and to consider them within the government policies.

A series of policy recommendations and proposals for future research have merged from this study. First of all, it would be interesting to analyze the effect of this new group of variables on international integration. Furthermore, it is obvious that among countries the differences related to distance are more pronounced, such as religion, language, poverty levels and even the way of perceiving the world. Therefore, the inclusion of other variables with a possible effect on integration is necessary in the international case. For instance, in terms of policy elaboration, it may be relevant to know whether culture similarities or geographical distance are more important in terms of increasing the integration. In this regard, the globalization process may indeed be a driver of countries' integrations.

Another important point of discussion arises from the results which indicate that only the Northern region of Brazil, where the rice is least important and government protection was minimal during the period of analysis, experienced structural breaks immediately after the Real Plan (1994) and during the agricultural crisis that followed. This might mean that the low protection on these markets accelerated the modification of the relationships, while in the other regions it was not necessary to make instantaneous adjustments since producers could maintain their income levels longer. In recent years, the level of protection for producers and consumers in the Northern region has increased, for instance with the inclusion of the Minimum Price Policy. This is an open door for a very interesting topic of analysis: the effect of this protection-increment on the integration measurements and their susceptibility to, for example, an economic crisis.

Additionally, a topic deserving further attention is the differences in infrastructure among markets as a hampering of integration. In order to clarify this, we can imagine that two developed markets in terms of infrastructure which have high quality of roads can use big trucks to trade; however, one of these markets cannot use the same kind of trucks to export to a third market with a low development since the roads of this market cannot support them. In the research, the GDP per-capita results show this fact. It could be appropriate to expand the analysis in two directions. Firstly, the analyses could be split into the components of infrastructure, of which are many; for example telecommunications, airports, ports, number and quality of roads, etc. An outstanding example of the infrastructure effect can be found in the research of Jensen (2007), which found that the addition of mobile phones reduce 
the variability of price and increased producer profits and consumer welfare. This is because although these variables as a whole have been proven significant, knowing the order of importance is necessary for the determination of policy priorities. Secondly, in Brazil the regional disparities are huge while in smaller countries, such as Costa Rica and Nicaragua, this is not the case. The question which now arises is at what level of discrepancy in infrastructural development does this integration become a hindrance.

Together with the recommendation it is important to mention the limitations of the research. In this regard, the major limitation was the measure of geographical distance as the number of hours between capitals, given that this varies throughout the year as a consequence of the seasons. However, at the time there is no approximation which takes this fact into account. This is not only the case for Brazil, as most Latin-American countries share the same characteristic; the lack of a better indicator hinders the achievement of strong research conclusions and thus also a proper implementation of policies.

Another particular point of discussion is the use of the constant value from the long run equation as an approximation of transfer costs, although the results indicate that this is not a perfect approximation. This is firstly due to the use of this supposition to prove the Law of One Price (LOP) throughout the literature which applied the cointegration framework, and secondly to the lack of a methodology which allows for the inclusion of more than one unknown structural breaks and a more flexible approximation of the transport costs at the same time. Therefore, it is recommended that future approaches take this into consideration and tackle the solution to this lack of methodological knowhow. Nevertheless, this does not invalidate the fact that the above mentioned variables have an effect on integration and that their omission causes a bias in the distance coefficient.

\subsection{Spatial Price Transmission of the Rice Market of Northeastern Brazil and Variables which} Affect It

\section{Overview}

During the expansion of the last paper, an interest grew for the specific case of the North Eastern (NE) region of Brazil. This is the poorest region of the country and is second in terms of population. Here rice is a staple diet item and in the poorest states it is responsible for more than $30 \%$ of the total caloric consumption. This, together with the fact that the NE imports around $75 \%$ of its consumption, was what caught our attention and interest. Such a sensible region in terms of food security must be analyzed separately; by doing so, it is possible to provide policy markers a firm bases to protect the health and the quality of life for these people.

The relationships among the states of the $\mathrm{NE}$ and the rest of Brazil as well as the international principal exporters were analyzed. The Vector Error Correction Model (VECM) proposed by Johansen (1995) was applied. Additionally, in order to allow for the presence of structural breaks, the process suggested by Lütkepohl, Saikkonen and Trankler (2004) was included. 
The results suggest that the NE is partially isolated from the rest of the markets since only $40 \%$ of the relationships share a common long run path. Nonetheless, most of the significant integrated relationships show elasticities of cointegration above 0.65 . However, the two poorest states, Maranhão and Piauí, show the lowest number of cointegrated relationships which are weak in terms of the elasticity and speed of adjustment. This means that the food security of the poorest NE region does not face the high risk of an elevated increment in the prices in response to the movement of its trading partners`prices.

Nevertheless, the document also included a second part in which four possible variables which could change the integration relationship were examined. These variables are in part drawn upon from the preceding research analysis, and are the following: GDP, access to a main unloading port, geographical distance between the markets and, in the case of a relationship with international markets, what the trading partner country is. In this respect, distance and having a main port were found significant in the definition of the integration. Taking the investment in improvement of road and port quality into consideration as well, from the policy making point of view these results suggest an increment in the integration of the NE with its partners in the foreseeable future, and therefore the need for a periodic analysis of the integration behaviour of this region.

An unexpected finding was that the probability of finding an integrated relationship with Argentina is higher than with Uruguay, even though the latter exports a larger amount of rice. It could be related to the fact that in Uruguay the prices are defined by means of an agreement negotiated between the industry and the producer while in Argentina it is through the markets forces.

\section{Discussion}

The contents and ideas of this document mainly contribute to the policy analysis toolkit. Two principal findings have been presented. Firstly, the results point out that the NE is isolated from the rest of the markets, especially its poorest states. Secondly, this will change in the near future in response to the improvement of roads and ports. Nonetheless, other relevant points also emerge from the analysis. For instance, the findings suggest that Pernambuco is the NE state with the highest amount of cointegrated relationships, which seems counter-intuitive since the consumption and production of rice here are some of the lowest in the region. However, what is shown is the relevance of having access to the external market by maritime route given that this state has two of the most important NE ports in terms of rice entry.

Next, another notable outcome is that the adjustments to deviations from the long run equilibrium are made as much for the NE markets as for the international market. The latter, as mentioned above, corresponds to Argentina's prices. This means that prices of the NE are susceptible to price increments and events happening in Argentina. This was also verified by the fact that the crisis in Argentina provoked structural changes in the integrated relationships. Therefore, it could be necessary to evaluate consumer protection measures in the case of a crisis in this market. 
Additionally, future research should take the net benefit ratio, which is the difference between the importance of the product for consumers (as percentage on the total household expenditures) or producers (as percentage on the total household income), into consideration. The NE is a producer and a consumer region, where the importance of rice in the total expenditures vs. the total income vary among states, therefore the policy recommendations per state also vary. For instance, the policy measures required in a state with an important loading port will be different whether the net benefit ratio is positive or negative. In this regard, the fact that Argentina has lower level of prices than Brazil, in case of a positive change in integration with international prices, would probably result in a decrease in rice prices. This means a gain of welfare when the net benefit ratio is negative or a lost when is positive. Moreover, as mentioned before, the net benefit ratio related to the poorest people would be different than the state one. This is especially relevant In the NE since the most vulnerable group of Brazilian in terms of food security is located here. Moreover, the policy coherence between measures apply to rice market and other policy objectives, for instance improvement in the nutrition of children, should be analysed in the light of the conjunction between price transmission results and the net benefit ratio, for example, estimating the latter for the subgroup of poor household with children.

In addition, in this research is applied the cointegration framework suggested by Johansen (1995) while the last paper applied Engle and Granger's (1986) two step procedure. The decision to apply a different approach in the analysis of the NE is due the different strengths and weaknesses that each methodology has, and by doing so, to be able to compare whether the results are reliable. One of the weaknesses of Engle and Granger's approach which led us to this decision was that in the last paper an important amount of observations (44\%) were excluded since this methodology requires one of the two prices to be designated as exogenous. In order to fulfil this, the pairs of prices which affect each other were excluded. Nevertheless, this methodology has the possibility to include more than one unknown structural break as an advantage while in the case of Johansen it is not possible. In this regard, taking the relationships of all Brazilian sectors and the equations which included structural breaks into consideration, it is particularly noticeable that with the Johansen methodology cointegration was more likely to be rejected. This might be associated with the fact that the Johansen approach only allows for one structural break in the constant coefficient while, according to the results from the Engle and Granger`s approach, there are relationships which show more than one significant break with changes in the intercept as well as in the slope. It also should be added that Engle and Granger's approach without a break shows a higher probability of rejecting cointegration.

Regarding the timing of the breaks, the results are strong; estimates were made using the Johansen approach with the modifications suggested by Lütkepohl, Saikkonen and Trankler (2004), where in most of the cases similar to those obtained with Engle and Granger's methodology using the procedure recommended by Bai and Perron (1998) and modified by the significant values proposed by Kejriwal and Perron (2010). The break times are concentrated around two main events in both cases: the Plan Real and the crop failures of Rio Grande do Sul. Nevertheless, in the last document, when more than one event is allowed to occur, the liberalization of the currency in 1999 was also significant. 
With regard to the variables with an effect on integration, geographical distance and the presence of a main port presented the same sign in both documents. However, the effect of the latter was higher in the second paper. Nevertheless, both approaches support the idea of a future growth in integration.

\subsection{References}

Alfaro, O., E. Ducca, O.M. Solano, \& C. Zumbado; (2007). “Caracterización y Plan Acción para el Desarrollo de la Agrocadena de Ganado Bovino en la Región Huetar Norte”. Ministerio de Agricultura (MAG), Ciudad Quesada, Costa Rica. (http://www.mag.go.cr/bibliotecavirtual/ac-ganaderia-rhn-2007.pdf).

Bai, J., \& P. Perron; (1998). “Estimating and Testing Linear Models with Multiple Structural Changes”. Econometrica, 66 (1) pp 47-78.

Balke, N.S., \& T.B. Fomby; (1997). "Threshold Cointegration". International Economic Review, 38(3) pp 627-645.

Camara Nacional de Productores de Leche; (2010). “Congreso Nacional Lechero: Situación Actual, Desafíos y Oportunidades de la Lechería en Costa Rica Visión de la Cámara Nacional de Productores de Leche”. San José, Costa Rica. (http://www.proleche.com/).

Charalambos, A.P.; (1999). "Price and Income Elasticities of Disaggregated Import Demand: Results from UECMS and an Application”. Applied Economics, 31 (9) pp 1061-1071.

Conforti, P.; (2004). "Price Transmission in Selected Agricultural Markets". FAO Commodity and Trade Policy Research Working Paper, 7.

Corporacion Ganadera (CORFOGA); (2001). "Estudio de Mercado Hábitos de Consumo de Carne". (www.mag.go.cr/biblioteca_virtual_animal/habitos_consumo_carne.pdf).

Dutoit, L., K. Hernández \& C. Urrutia; (2010) “Transmisión de Precios en los Mercados del Maíz y Arroz en América Latina” (Price Transmission in Latin American Maize and Rice Markets). Serie CEPAL: Desarrollo Productivo. ISBN: 978-92-1323464-8.

Engle, R.F., \& C.W.J. Granger; (1987). “Cointegration and Error Correction: Representation Estimation and Testing”. Econometrica, 55 pp 251-276.

Granger, C.W.J., \& T-H Lee; (1989). "Investigation of Production, Sales and Inventory Relationships Using Multicointegration and Non-Symmetric Error Correction Models”. Journal of Applied Econometrics, 4 pp 145-159.

Hernández, K.; (2010). "Asymmetric Price Transmission and Structural Breaks in the Relationship between Costa Rican Markets of Livestock Cattle, Beef and Milk". The Journal of Agricultural Science and Technology, 4 (5) (Serial No.30) pp $37-50$.

Hidalgo, C., Monge, A. Cruz., JR. Molina, J. Camacho, G. Vargas, \& O. Barrientos; (2004). "Informe Parcial del País Sobre la Situación Nacional de los Recursos Zoo Genéticos". Subcomisión Nacional Encargada de la Elaboración del Informe País Sobre la Situación de los Recursos Genéticos Pecuarios de Costa Rica, pp 43.

Holmann, F., R. Libardo, E. Pérez, et al.; (2007). "La Cadena de Carne Bovina en Costa Rica: Identificación de Temas Críticos para Impulsar su Modernización, Eficiencia y Competitividad, International Livestock”. Research Institute (ILRI), Centro Internacional de Agrícultura Tropial (CIAT), Corporación Ganadera (CORFOGA). (http://www.corfoga.org/images/public/documentos/pdf/cadena_carne_bovina_CR.pdf).

Jensen, R.; (2007). "The Digital Provide: Information (Technology), Market Performance, and Welfare in the South Indian Fisheries Sector". The Quarterly Journal of Economics, 122(3) pp 879-924. 
Johansen, S.; (1995). "Likelihood-based Inference in Cointegrated Vector Autoregressive Models". Oxford University Press, Oxford.

Jolliffe, I.T.; (2002). "Principal Components Analysis". 2nd ed. Springer, pp168-181.

Kejriwal, M., \& P. Perron; (2010). "Testing for Multiple Structural Changes in Cointegrated Regression Models". Journal of Business \& Economic Statistics- American Statistical Association, 28(4) pp 503-522.

Lerner, A.P; (1934). "The Concept of Monopoly and the Measurement of Monopoly Power". The Review of Economic Studies, 1(3) pp 157-175.

Lütkepohl, H., P. Saikkonen, \& C. Trenkler; (2004). "Testing for the Cointegrating Rank of a VAR Process with Level Shift at Unknown Time”. Econometrica, 72 (2) pp 647-662

Minot, N.; (2010). "Transmission of World Food Price Changes to African Markets and its Effect on Household Welfare". paper presented at the Comesa policy seminar "Food price variability: Causes, consequences, and policy options" on 25-26 January 2010 in Maputo, Mozambique under the Comesa-MSU-IFPRI African Agricultural Markets Project (AAMP).

Mckenzie, C.C., \& W.L. Nieuwoudt; (1985). "Estimation of the Demand and Supply Functions for Fresh and Industrial Milk In South Africa". Agrekon, 24(2) pp 27-33.

Mevik, B., \& R. Wehrens. (2007).“The pls Package: Principal Component and Partial Least Squares Regression in R”. Journal of Statistical Software, 18(2) pp 1-24.

Programa Estado de la Nación; (2011). "Informe Estado de la Región en Desarrollo Humano Sostenible. Capítulo 3: Equidad e integración social”. Programa Estado de la Nación: San José, Costa Rica.

Quiros, R. (ed.); (2006). "Resumen de la conferencia: Financiamiento de las Cadenas Agricolas de Valor". San José, Costa Rica (ISBN: 9977-21-073-5).

Ramzan, S., \& M. Inayat Khan; (2010). "Dimension Reduction and Remedy of Multicollinearity Using Latent Variable Regression Methods”. World Applied Science Journal, 8(4) pp 404-410.

Ravallion, M.; (1986). "Testing Market Integration". American Journal of Agricultural Economics, 68 pp 102-09.

Song, J., \& D. Summer; (1999). “Dairy Demand, Supply and Policy in Korea: Potential for International Trade”. Canadian Journal of Agricultural Economics, 47 pp.133-142.

Teräsvirta, T.; (1998). "Modeling Economic Relationships with Smooth Transtition Regressions” A. Ullah \& D. Giles (eds), Handbook of Applied Economic Statistics (229-246). New York: Dekker.

Teräsvirta, T. ; (2004). "Smooth Transition Regression Modelling”. H. Lütkepohl \& M. Krätzig (eds), Applied Time Series Econometrics. Cambridge: Cambridge University Press.

von Cramon-Taubadel, S.; (1998). "Estimating Asymmetric Price Transmission with the Error Correction Representation: An Application to the German Pork Market”. European Review of Agricultural Economics, 25(1) pp 1-18. 


\section{Chapter 3}

\section{Asymmetric Price Transmission and Structural Breaks in the Relationship between Costa Rican Markets of Livestock Cattle, Beef and Milk}

\subsection{Introduction}

Researchers to date have classified price transmission (PT) according to the type of link maintained by the markets. In the first place, spatial PT takes place between two markets where the characteristics of the products are close to being the same, but are separated by transportation costs. Secondly, the vertical PT corresponds to the relationship between two markets of the same production chain (Meyer \& von Cramon-Taubadel, 2004). However, there is another aspect associated with vertical PT which is focused on the relationship of two or more joint products produced in a single production process using common input (i.e.: soybean oil and soybean meal, wool and mutton) (Gardner, 1987).

An example of a pair of joint products exists in the beef meat and milk markets of Costa Rica. In many countries these goods are produced primarily in disconnected chains. Nevertheless, in Costa Rica roughly $27 \%$ of farms use cattle to produce both meat and milk. They are referred to as "double intention farms" (Holmann et al., 2007).

In order to do appropriate analyses of these joint products it is essential to take the specific characteristics of their relationship into account. First, the biological features of the livestock cattle used during the production process affect the decision making of farmers. For example, a farmer may decide to withhold cows in order to produce milk instead of slaughtering them for meat production. This behavior might be asymmetric, i.e., farmers may react differently if the cost of keeping a cow for milk production rises rather than declines. Beef production can be increased quickly by slaughtering whereas it takes more time for a calf to become a lactating cow. Asymmetric behavior within beef and milk markets has been carried out in previous investigations of PT. For instance, Zheng et al. (2008) found asymmetry to be present in the beef sector of the US farm-wholesale and wholesale-retail price relationship, but not in the milk production chain.

Another important aspect is the alterations over a period of time in the relationship between variables. For example, changes in government legislations, economic conditions and international situations related to the products can provoke structural changes that modify the link between the related variables. In the presence of structural breaks the results could be biased. Therefore, the estimation of 
the equation allowing for presence of breaks is central for obtaining robust conclusions (Zhang et al., 2006).

The objective of this research is to analyze the price transmission between Costa Rican cattle, beef and milk markets while accounting for asymmetric behavior and structural breaks in the long run equilibrium. This third Chapter is organized into 6 sections. Section 2 presents the current structure of the livestock, beef and milk markets and their interrelationships. Section 3 describes the hypothesis and Section 4 the methodology adopted. The $5^{\text {th }}$ Section provides a short description of the data and its sources. Section 6 presents the empirical results and their implications. Finally, Section 7 contains concluding remarks.

\subsection{The Case of Costa Rica}

\section{a. The Livestock Sector in Costa Rica}

The livestock sector has played an important role in the historical and economic development of Costa Rica over the past 250 years (Quirós; 2006). This evolution has resulted in the current situation of the livestock sector occupying the biggest proportion of land, followed by naturally protected areas. This has generated significant environmental externalities (Bertsch, 2006). In addition, livestock production in Costa Rica employs $12 \%$ of the agricultural workforce, the majority of which are employed in cattle breeding.

Livestock production has accounted for a $22 \%$ share of the agricultural sector in the last three decades (Figure 3.1). Nevertheless, on the whole this industry has lost importance. However, the dairy sector alone has experienced a dynamic growth of 3.5\% between 1996 and 2006 (CPL, 2007). Therefore, the market share of beef and/or cattle production has declined, on average, $0.1 \%$ per year since the $1980 \mathrm{~s}$ (CORFOGA, 2005). 
Figure 3. 1

Added Value of Livestock

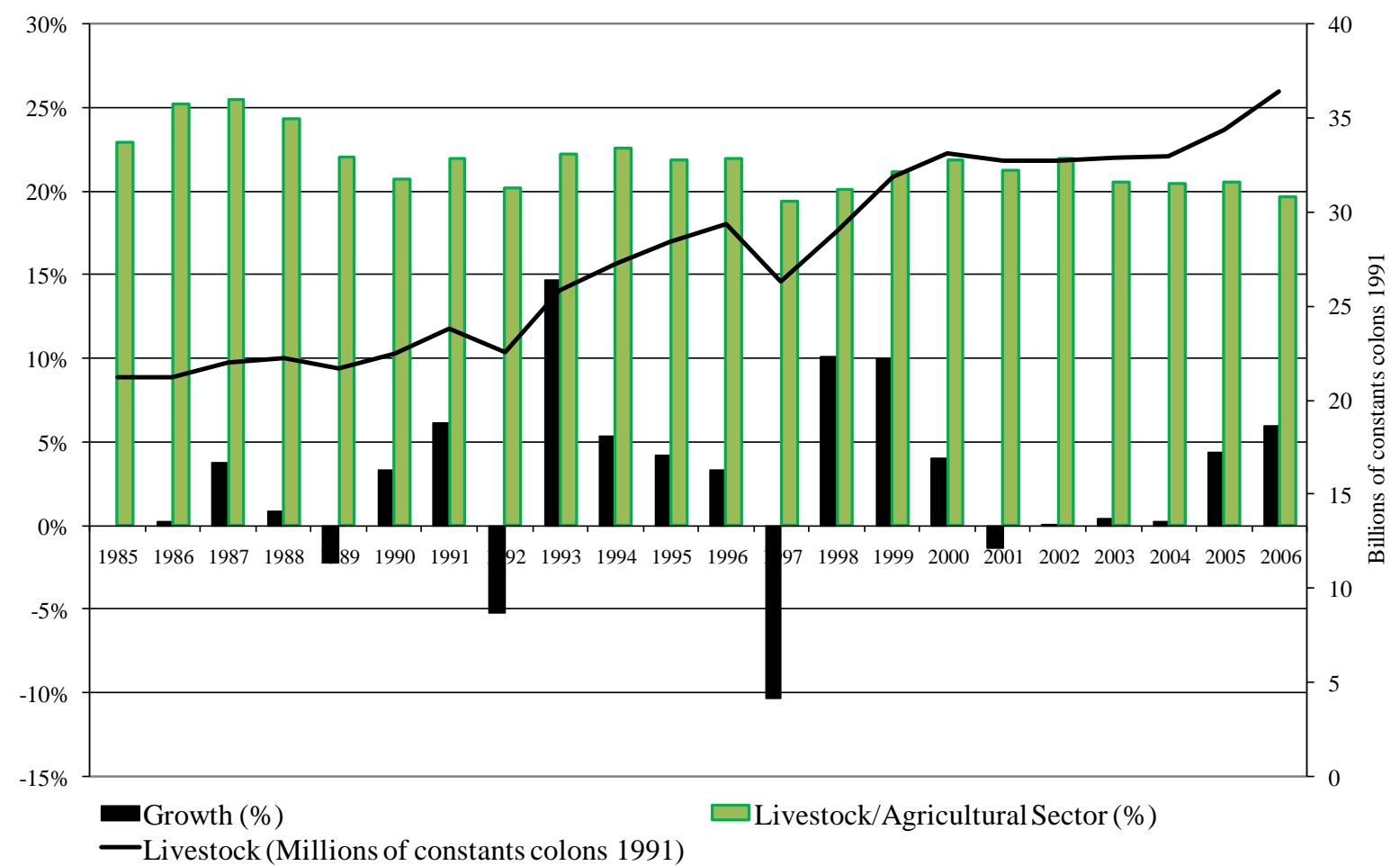

Source: Date MAG, 2006.

In Costa Rica the dairy and beef sectors cannot be regarded as independent from each other as a significant amount of producers are classified as double intention farms, meaning farm activities occur in both the beef and dairy sectors. Roughly $22 \%$ of the animals belong to double intention farms while $65 \%$ belonging to beef and $13 \%$ to dairy farms (CORFOGA, 2001). According to the Census 2000, $23 \%$ of the farms participate in double intention production (CORFOGA, 2001). It is worthwhile to note that the double intention farms use Cebu animals primarily to produce milk and beef cattle, however, the Cebu cattle are known for being more productive in terms of meat production (CORFOGA, 2001).

\section{b. The Beef Chain and the Meat Sector in Costa Rica}

Meat is an important component of the traditional Costa Rican diet. According to a study performed by CORFOGA (2001a), 53\% of the population earning lower wages (less than $216 \mathrm{USD} / \mathrm{month}$ ) and $67 \%$ of those with the highest incomes (more than 900 USD/month) consumed beef at least twice per week. Regardless of these statistics, beef consumption per capita has declined over the past 20 years. It has been argued that beef has been increasingly substituted by other meat products, such as poultry and pork (Figure 3.2). It is worthy to note that consumers do not have the same preferences for all types of cuts. Ground beef (26.01\% of families), steak of first quality (24.3\%) and loin (11.46\%) are the most preferable cuts (CORFOGA, 2003). 
Figure 3. 2

Consumption of the Principal Meat Products

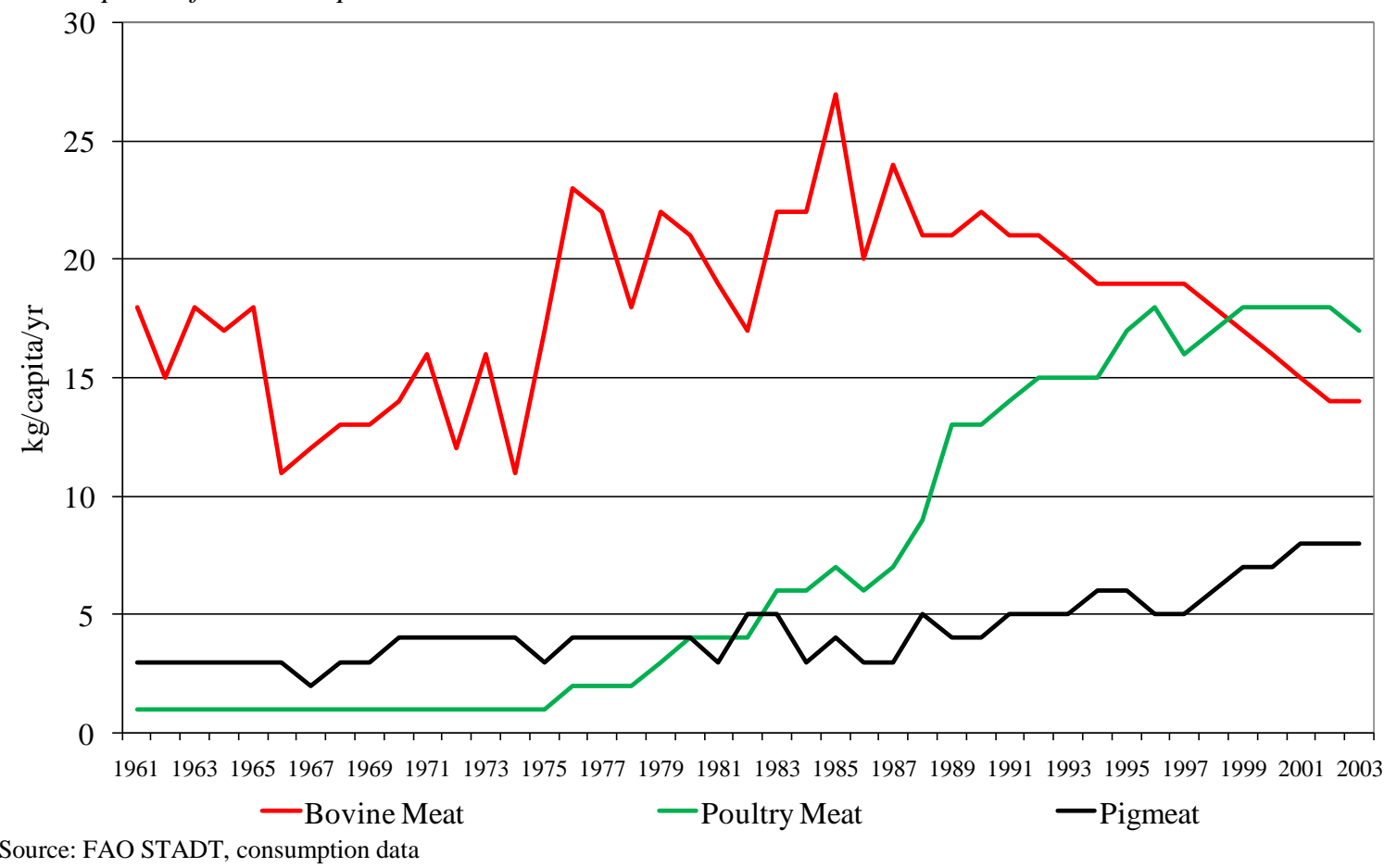

When discussing the beef cattle chain, there are two principal options where the farmer can sell beef cattle. The most popular option is the auction, which are important for cattleman because it is easier to determine patterns of the prices. The other principle option is the industry sector which is responsible for the slaughter, deboning and packing of the cattle. It has been found that there are three principal enterprises which slaughter between 70 to $80 \%$ of the livestock in Costa Rica (Holmann et al., 2007).

\section{c. The Milk Cattle Chain and Milk Sector in Costa Rica}

Over the last 50 years milk demand in Costa Rica alone has experienced a remarkable increase, which is even higher in comparison to the rest of Central America. In fact, the consumption of per capita milk is greater than 200 liters per year (Quiros, 2006).

The milk producers have three commercialization channels: industrial, informal and self-consumption. Between $54 \%$ and $61 \%$ of the national production flows through the industrial channel which is dominated by vertically integrated cooperatives.

The principal cooperative is "Dos Pinos", which produces $85 \%$ of the industrial milk products. Dos Pinos influences the sector in a strong way. First, its huge share of the market has made this enterprise the leader in determining milk prices. Secondly, Dos Pinos has established contracts with the associates of the cooperative guaranteeing to buy the totality of their production. The arrangement states that the producer must sell all of the milk produced to Dos Pinos. One of the issues with such an agreement is that when there is an adjustment in prices, for example an increase in production costs, the final price paid must be enough to compensate for a cost increase, but not too much to lose demand (Barquero, 2001; Fallas, 2007; Fallas; 2008; Leitón, 2002). 


\section{d. Important Changes in the Milk and Beef Markets}

In the case of beef and livestock there are two important international shocks which have changed the behavior of the markets. First, the demand of beef increased from 2004 to 2005 when China stopped the importation of beef products from the USA and began importing beef from others markets, which caused a raise in international prices (Leitón, 2005; Rojas, 2005). Secondly, there was an increase in the international prices of soya beans, fish meal, and other products which are used in the diet of the animals. Even though herd alimentation is based mainly on grass consumption in Costa Rica, maintaining a constant supply of quality pasture is impossible. Hence, farmers must resort to supplementary alimentation, thus increases in the prices of these products affect the cost of livestock production. Between 2002 and 2004 a strong upward growth in supply prices caused an increase of about $30 \%$ in raw material prices (Barquero, 2007). Figure 3.3 displays international price trends which grew around 2005/6 to 2006/6. This situation also affected the milk market.

Figure 3. 3

International Prices of the Feed Products

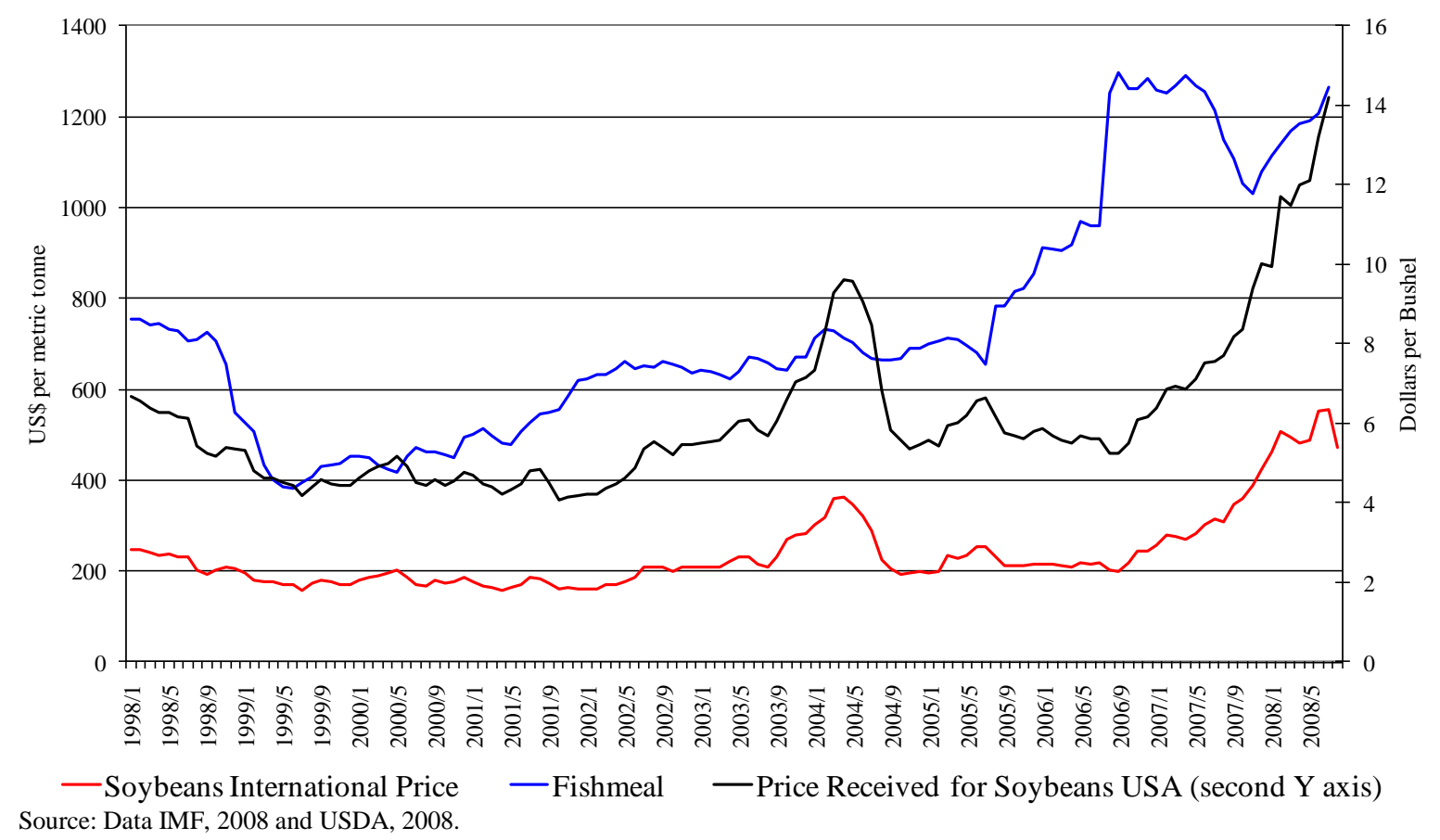

In addition, there was another significant change in the milk market. After 2002 Dos Pinos sold fluid milk below the price needed to cover production costs. Since 2002 the company policies have been modified so price adjustments are in line with production costs (Leitón, 2002). The result is shown in Figure 3.4 which displays the positive tendency of milk powder. 
Figure 3. 4

Log of Prices Beef Meat, Milk and Livestock Markets, 1998/1 - 2008/4

Dollars

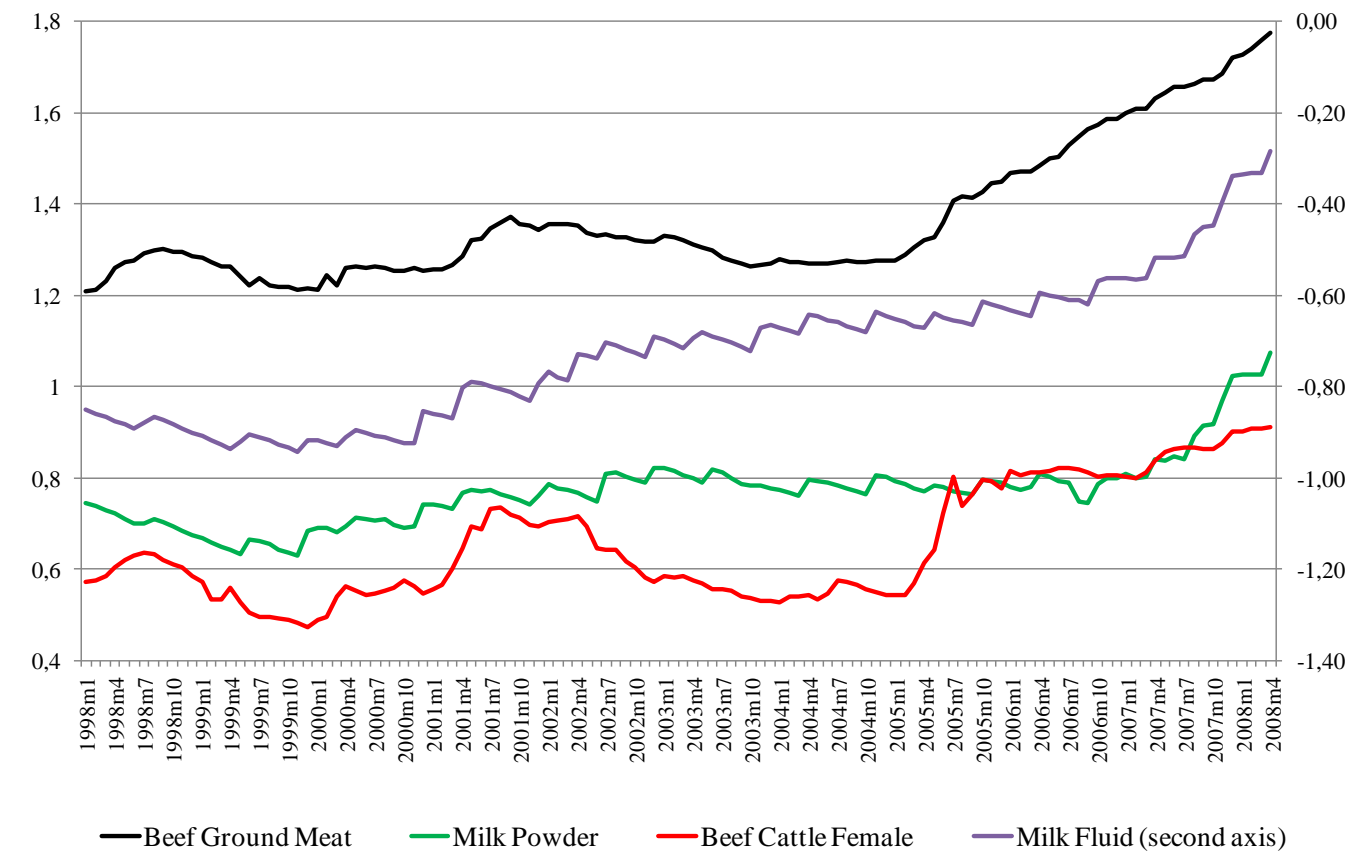

Source: Author's Elaboration.

\subsection{Methodology}

The Augmented Dickey-Fuller (ADF) was primarily used to test for the presences of unit roots (Kwiatkowski et al., 1992). However, the changes which happened during 2002 and 2005-2006 are a sign of the possible break in the behavior of the variable in the long run; thereby, the UR test has been used in order to account for structural breaks (Saikkonen \& Lütkepohl, 2002). The break point was selected following the recommendations of Lanne, Lütkepohl \& Saikonen (2003).

In cases where the variables were not stationary, cointegration methods were used to test for the existence of a non-spurious long run equilibrium relationship between them (Kirchgässner \& Wolters, 2007). Before applying the cointegration techniques, and once the order of the series was determined, the long run equilibrium was calculated using the following equation:

$P_{t}^{y}=\beta_{0}+\beta_{1} P_{t}^{x}+\mu_{t}$

Where $P_{t}^{y}$ is the dependent variable, $P_{t}^{x}$ the independent variable (both correspond prices) and $\beta_{0}$ is the constant coefficient. The rest are unknown coefficients. In fact, the errors $\mu_{t}=P_{t}^{y}-\beta_{1} P_{t}^{x}-\beta_{0}$, also called the Error Correction Term (ECT), represent deviations from the equilibrium in the short run. In the long run, $\mathrm{E}\left(\mu_{t}\right)=0$, since deviations are to offset one another for the equilibrium to be maintained (Rapsomanikis et al., 2003; Hendry \& Juselius, 2000). In addition, a trend is included in equation (3.1) when it is significant at the $5 \%$ level.

In some cases the long run equilibrium was held over periods of time, and then shifted to a new long run relationship. The omission of this situation might have provoked bias in the results. In order to 
find evidences of structural breaks, the CUSUM and CUSUM Square tests have been employed in order to analyze the stability of the equation (Annex 3.1, Figure 3.6-3.12).

Based on the information related to the changes in the markets and the CUSUM analysis the period of break was located. Next, it was applied using the model suggested by Gregory and Hansen (1996) which considers the idea of cointegration allowing for structural breaks. In this context it is defined as:

$$
\psi_{t \tau}=\left\{\begin{array}{lll}
0 & \text { if } & \tau \leq[n \tau] \\
1 & \text { if } & \tau>[n \tau]
\end{array}\right.
$$

Where the parameter $\tau \in(0,1)$ denotes the timing of the change point, and [ ] denotes the integer part. The regime shift model introduces different possible structural breaks into the cointegration equation:

Relation of cointegration with a break in the constant:

$$
P_{t}^{y}=\beta_{0}^{1}+\beta_{0}^{2} \psi_{t \tau}+\beta_{1}^{1} P_{t}^{x}+\mu_{t}
$$

Relation of cointegration including a trend and with a break in the constant:

$$
P_{t}^{y}=\beta_{0}^{1}+\beta_{0}^{2} \psi_{t \tau}+\beta_{1}^{1} P_{t}^{x}+\delta t+\mu_{t}
$$

Relation of cointegration with a break in the constant and in the slope:

$$
P_{t}^{y}=\beta_{0}^{1}+\beta_{0}^{2} \psi_{t \tau}+\beta_{1}^{1} P_{t}^{x}+\beta_{1}^{2} \psi_{t \tau} P_{t}^{x}+\delta t+\mu_{t}
$$

Where $\beta_{0}^{1}$ represents the intercept before the shift and $\beta_{0}^{2}$ represents the change in the intercept at the time of the shift. $\beta_{1}^{1}$ denotes the cointegration slope coefficients before the regime shift, and $\beta_{1}^{2}$ denotes the change in the slope. In view of $\tau$ it is deduced before (using the stability analysis) the resulting equilibrium relationship can be estimated using ordinary lest squares (OLS) (Gregory \& Hansen, 1996). In order to select the model which better describes the long run equilibrium, the Likelihood Ratio test and the R-square test was computed for each model and the long run relationship with better adjustment has been selected.

Thereafter, using the methodologies proposed by Engle-Granger (1987) and Johansen (1995), cointegration tests were carried out on the pairs of prices. In the case of Engle-Granger two different tests were used to test the stationarity of the error term $(\mu)$, in which case $P_{t}^{y}$ and $P_{t}^{x}$ were cointegrated. First the ADF test with adjusted critical values, and secondly the Dickey-Fuller General Least Squares (DF-GLS) were applied. Prior to that, the significant numbers of lag were calculated, which computed the final prediction error (FPE), Akaike's information criterion (AIC), Schwarz's Bayesian information criterion (SBIC), and the Hannan and Quinn information criterion (HQIC). After that the Johansen trace test (Johansen, 1995) was computed with the intention of determining the cointegration range of the relationship. Here the trend was only included in those cases when it was significant inside the long run equilibrium. 
Until this point it was known if price transmission exists between the markets (milk, beef and livestock) and the cointegration coefficient $\left(\beta_{1}\right)$. Furthermore, in view of the variables the logs of the prices, $\beta_{1}$, could be interpreted like an elasticity. Only the short run analysis of the relation remained. At this point the Error Correction Model (ECM) was applied to estimate the following:

$$
\begin{aligned}
& \Delta P_{t}^{y}=\alpha_{y} E C T_{t-1}+\sum_{j=1}^{n_{x}} \Gamma_{j}^{y} \Delta P_{t-j}^{y}+\sum_{j=1}^{n_{y}} \Gamma_{j}^{x} \Delta P_{i-j}^{x}+\delta_{i} D_{i}+\varepsilon_{t}^{y} \\
& \Delta P_{t}^{x}=\alpha_{x} E C T_{t-1}+\sum_{j=1}^{m_{x}} \Phi_{j}^{y} \Delta P_{t-j}^{y}+\sum_{j=1}^{m_{y}} \Phi_{j}^{x} \Delta P_{t-j}^{x}+\delta_{i} D_{i}+\varepsilon_{t}^{x}
\end{aligned}
$$

The variable $\Delta \mathrm{P}_{\mathrm{t}}^{\mathrm{i}}(\mathrm{i}=\mathrm{x}, \mathrm{y})$ is the change in price $\mathrm{i}$ which is affected by past deviations from the equilibrium $\left(\mathrm{ECT}_{\mathrm{t}-1}\right)$ and by past changes in both prices $\left(\Delta \mathrm{P}_{\mathrm{t}-1}^{\mathrm{y}}\right.$ and $\left.\Delta \mathrm{P}_{\mathrm{t}-1}^{\mathrm{x}}\right)$. The $(\mathrm{ECT})$ is defined as the error $(\mu)$ of the long run equation described by the equation with the better adjustment between (3.2.1), (3.2.2) and (3.2.3). $\alpha_{i}$ represents the adjustment of prices on the left hand side to the deviations from this long run equilibrium. $\Gamma_{i j}$ and $\Phi_{y j}$ are the short term parameters associated with lagged price changes, and $\delta_{i}$ are the dummy coefficients. The optimal number of lags corresponds to the maximum number among the AIC, HQ, SC and the FPE criterions. When $\alpha_{y}$ is significant and $\alpha_{x}$ is not, any deviation from the long run relationship will cause an adjustment in $P_{t}^{y}$ but not in $P_{t}^{x}$.

Finally, the asymmetric behavior was tested. There is more than one definition of asymmetric when referring to price transmissions. For the aim of this paper, the interest is the asymmetry in the speed of adjustment towards the equilibrium level (Frey \& Manera, 2007). Granger and Lee (1989) propose a modification to equations (3a) and (3b) where ECT is split into positive and negative components, and the difference between the $\alpha_{i}$ of each of them is tested with a Likelihood Ratio test.

\subsection{Hypotheses}

Given the characteristics of the three markets, the following hypotheses and expectations are derived. Since the price of milk is principally determined by Dos Pinos, it is expected that milk prices would not adjust to correct any deviations from any of the two long run equilibriums, (milk-livestock and milk-beef).

Furthermore, the livestock price was expected to adjust to changes in milk prices because of the influence of double intention farms over the supply of cattle to slaughter, as the opportunity costs of keeping a cow are affected by milk price changes. Moreover, the meat prices would adjust to changes in the livestock prices since the quantities of beef cattle to slaughter alter the supply of beef. In that case, it would be a relationship between the milk and meat markets caused by the link of both market to the livestock market. The hypotheses are displayed as a diagram in Figure 3.5. 
Figure 3. 5

Joint Products: Relationships between the Livestock, Beef Meat and Milk Markets in Costa Rica

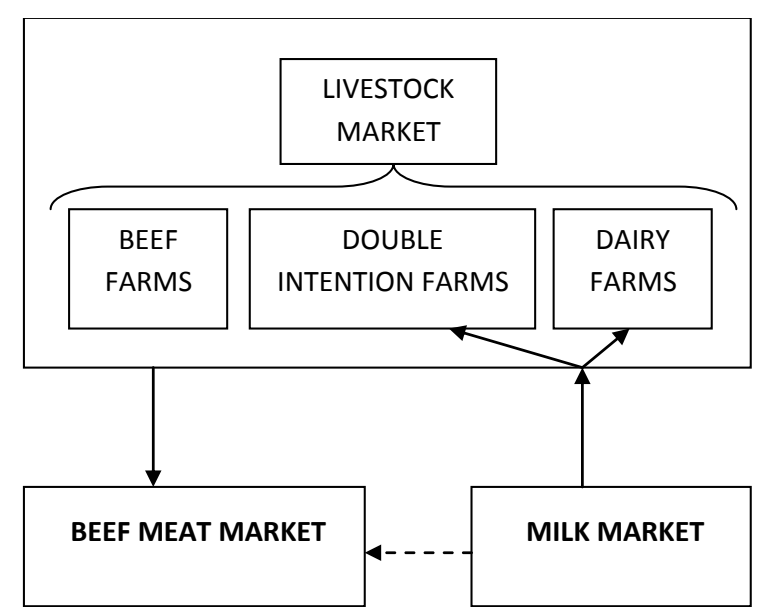

APT is expected within the adjustment to the long run equilibrium. In the milk-livestock relationship we expect that when the difference from the long run equilibrium is positive, livestock prices would adjust more rapidly than when it is negative. That is because it is easier to send a cow to slaughter than to increment the herd to produce milk, so it is reasonable to expect faster adjustments in the case of a disincentive in the production of milk. The livestock-beef relationship could be affected by the market power; thus, we expect that the large slaughter firms would adjust the beef price more rapidly to livestock price increases than decreases.

\subsection{Data}

Monthly price data was collected covering the first month of 1998 to the fourth month of 2008. In the milk and meat cases, consumer prices were obtained from the National Statistic Institute of Costa Rica (INEC). Beef cattle prices were provided by the National Council of Production.

The beef prices market is represented by ground meat (the most consumed beef product in Costa Rica), and it corresponds to the dollar (US) per kilo price of the product. The milk price corresponds first to price per liter of homogenized milk (fluid milk) and second to the price for 400 grams of powdered milk. Livestock prices correspond to the purchasing price of producers for live female cattle for slaughter (carcass price). For the econometric analysis the prices are used in logarithms (Figure 3.4). It is worth it to note that the behavior of both milk prices is characterized by "stairs-form" changes. These correspond to the adjustment of the prices caused by Dos Pinos which strongly affects the performance of the entire market. The results were calculated using the econometric programs JMulti and STATA. 


\subsection{Empirical Results}

Prior to initiating the cointegration analysis, time series properties of the variables are analyzed. Using the ADF test, we cannot reject the null hypothesis of a unit root at the $10 \%$ significance level for any of the prices (Table 3.1). Nevertheless, the fluid milk price is stationary at the 5\% significance level when the test is carried out without a constant and trend. However, the variable is considered nonstationary since in the VAR model, which was used to estimate the ADF test, both the constant and trend are statistically significant at the 5\% level. We also used the UR test which allows for structural breaks. The first difference of beef ground meat and female beef cattle are not I (0). Nevertheless, when the optimum lag number is chosen taking the Schwarz Criterion into account, the ground beef meat corresponds to a non-stationary or I(1) variable. Even so, based on the preponderance of evidence, we consider all four prices as non-stationary in the following analysis and differentiate them once to achieve stationary.

Table 3. 1

Results of Unit Root Tests

\begin{tabular}{|c|c|c|c|c|c|c|c|c|c|c|}
\hline \multirow{3}{*}{ Variables (Prices) } & \multicolumn{3}{|c|}{ Augmented Dickey-Fuller ${ }^{1}$} & \multicolumn{7}{|c|}{ UR with Structural Break } \\
\hline & \multirow{2}{*}{$\begin{array}{c}\text { Constant } \\
\text { and Trend } \\
\text { Value }\end{array}$} & \multirow{2}{*}{$\begin{array}{c}\text { Constant } \\
\text { Value }\end{array}$} & \multirow{2}{*}{$\begin{array}{c}\text { Without } \\
\text { constant } \\
\text { and Trend } \\
\text { Value }\end{array}$} & \multirow{2}{*}{$\begin{array}{c}\text { Break } \\
\text { Point }\end{array}$} & \multicolumn{2}{|c|}{ with trend } & \multicolumn{2}{|c|}{ without trend } & \multicolumn{2}{|r|}{ lags } \\
\hline & & & & & AIC & Schwarz & AIC & Schwarz & AIC & Schwarz \\
\hline Log Beef Ground Meat & -0.54 & 1.55 & 1.68 & $2005 \mathrm{~m} 7$ & 1.54 & 3.40 & -2.25 & -0.71 & 3 & 0 \\
\hline Log Female Beef Cattle & -2.45 & -1.17 & 0.36 & $2005 \mathrm{~m} 8$ & -1.15 & -0.68 & -2.48 & -1.80 & 3 & 1 \\
\hline Log Milk Powder & -1.02 & 0.90 & 1.60 & $2002 \mathrm{~m} 7$ & 1.41 & 0.33 & -1.23 & -1.60 & 2 & 0 \\
\hline Log Fluid Milk & -1.31 & 1.88 & $-2.33 * *$ & $2001 \mathrm{~m} 4$ & 2.28 & 1.31 & -1.31 & -1.85 & 2 & 0 \\
\hline \multicolumn{11}{|l|}{ First diference } \\
\hline Log Beef Ground Meat & $-4.43 * * *$ & $-3.68 * * *$ & $-2.76 * * *$ & $2005 \mathrm{~m} 8$ & -1.13 & $-3.19^{* *}$ & -2.40 & $-4.99 * * *$ & 2 & 0 \\
\hline Log Female Beef Cattle & $-4.39 * * *$ & $-4.33 * * *$ & $-4.31 * * *$ & $2005 \mathrm{~m} 8$ & -1.11 & -1.54 & -1.89 & -2.45 & 2 & 0 \\
\hline Log Milk Powder & $-8.98 * * *$ & $-8.67 * * *$ & $-8.49 * * *$ & $2002 \mathrm{~m} 7$ & $-3.23^{* *}$ & $-3.23 * *$ & $-4.94 * * *$ & $-4.93 * * *$ & 1 & 1 \\
\hline Log Fluid Milk & $-9.98 * * *$ & $-9.41 * * *$ & $-4.68 * * *$ & $2001 \mathrm{~m} 4$ & $-4.07 * * *$ & $-4.07 * * *$ & $-5.37 * * *$ & $-5.37 * * *$ & 1 & 1 \\
\hline
\end{tabular}

*** means significance difference $P<0.01, * * 0.05, * 0.10$

${ }^{1}$ Lag length is selected according to the Akaike Info Criterion

Source: Author's Elaboration.

Table 3.2 shows the results of the long run equilibrium equation. First off, equations without breaks present elasticities of cointegration $\left(\beta_{1}^{1}\right)$ bigger than 0.6 , with the exception of the relationship between female beef cattle and milk powder. In contrast, and with the same exception, when the equation includes a structural break, the elasticities before the break do not exceed 0.6.

Since it was mentioned in Section 3, the CUSUM and CUSUM Square test was applied to determine the period of the possible structural breaks (Annex 3.1, Figures 3.6-3.12). In four of five equations the break corresponds to the first semester of 2005. This is in accordance with the period in which the 
price of soya beans in the USA experienced an intensive increase (Figure 3.3). Of notable mention is that after the period of break the elasticities are higher than before which evidences an increment in the cointegration relationship between the markets. This could be explained by the increment in the opportunity costs of keeping a cow. In order to identify the effect on the national relationships of the international raw material prices, the analysis of the price transmission should be included in a posterior analysis.

\section{Table 3. 2}

Long Run Equation

\begin{tabular}{|c|c|c|c|c|c|c|c|c|}
\hline $\mathrm{P}^{\mathrm{y}}$ (log prices) & $\mathrm{P}^{\mathrm{x}}$ (log prices) & $\beta_{1}^{1}$ & $\beta_{0}^{1}$ & $\beta^{1}{ }_{1}+\beta^{2}{ }_{1}$ & $\beta_{0}^{1}+\beta_{0}^{2}$ & $\begin{array}{c}\text { Log } \\
\text { Likelihood } \\
\end{array}$ & $\mathrm{R}^{2}$ & $\begin{array}{r}\text { Break } \\
\text { Point } \\
\end{array}$ \\
\hline Beef Ground Meat & Female Beef Cattle & $0.87^{* * *}$ & $0.73^{* * *}$ & & & 209.5 & 0.91 & \\
\hline Beef Ground Meat & Milk Powder & $0.72^{* * *}$ & $0.68^{* * * *}$ & & & 137.2 & 0.70 & \\
\hline Beef Ground Meat & Fluid Milk & $0.80^{* * * *}$ & $1.95^{* * * *}$ & & & 142.0 & 0.73 & \\
\hline Female Beef Cattle & Milk Powder & $0.48^{* * *}$ & $0.18^{* * *}$ & & & 133.7 & 0.56 & \\
\hline Female Beef Cattle & Fluid Milk & $0.60^{* * *}$ & $1.09^{* * * *}$ & & & 135.1 & 0.57 & \\
\hline
\end{tabular}

With a structural break

\begin{tabular}{lllllllll} 
Beef Ground Meat & Female Beef Cattle & $0.55^{* * *}$ & $0.93^{* * *}$ & $1.82^{* * *}$ & $0.01^{* * *}$ & 290.1 & 0.97 & $2006 \mathrm{~m} 3$ \\
Beef Ground Meat & Milk Powder & $0.44^{* * *}$ & $0.96^{* * *}$ & $1.13^{* * *}$ & $0.60^{* * *}$ & 191.6 & 0.88 & $2005 \mathrm{~m} 3$ \\
Beef Ground Meat & Fluid Milk & $0.17^{* * * *}$ & $1.42^{* *}$ & $1.06^{* * * *}$ & $2.13^{* * *}$ & 213.0 & 0.91 & $2005 \mathrm{~m} 3$ \\
Female Beef Cattle & Milk Powder & $0.64 * * *$ & $0.15^{* * *}$ & & $0.39^{* * *}$ & 193.2 & 0.83 & $2005 \mathrm{~m} 5$ \\
Female Beef Cattle & Fluid Milk & $0.49^{* * *}$ & $1.05^{* * *}$ & & $1.27^{* * *}$ & 185.3 & 0.81 & $2005 \mathrm{~m} 5$ \\
\hline *** mear
\end{tabular}

*** means significance difference $\mathrm{P}<0.01, * * 0.05, * 0.10$.

Source: Author's Elaboration.

The results of the cointegration analysis are summarized in Table 3.3. When structural breaks are not allowed for, the Johansen test suggests that there is not cointegration in the relationships which include the price of milk powder. This is also the case when the analysis includes the possibility of only one long run equilibrium between the three markets. Nevertheless, when a change in the long run relationship is allowed for, there is at least one cointegration vector linking the markets; the exception is the relationship of female beef cattle and milk powder.

In the Engle Granger test the results are affected by the criterion used to select the significant numbers of lags. The relationships beef ground meat- female beef cattle, beef ground meat-milk powder and beef ground meat-female beef cattle-milk there is no evidence of cointegration without breaks. However, they present some evidence when the structural change is included. It is worthy to note that the last two equations (Table 3.3), which include the three markets at the same time, exhibit signs of cointegration only when there is a structural break present.

Based on information provided in Section 3.2, the equations allowing for breaks are expected to better describe the real behavior of the relationships between the markets. Therefore, results with structural breaks are considered stronger. In this sense, the relationships between milk and livestock (female beef cattle) markets gives unexpected results (Table 3.3). The livestock market should be the connector 
between the milk and the beef meat markets; however, there is only weak evidence of cointegration between female beef cattle and the milk markets. The strong influence of Dos Pinos could hinder cointegration; for instance they provide financial support to those associates which face strong increases in raw material prices.

Table 3.3

Cointegration Test

\begin{tabular}{|c|c|c|c|c|c|c|}
\hline $\mathrm{P}^{\mathrm{y}}$ (log prices) & $\mathrm{P}^{\mathrm{X}}$ (log prices) & $\begin{array}{c}\text { Johansen } \\
\text { Trace Test }+\end{array}$ & Significant lags & $\begin{array}{c}\text { gle Granger Test } \\
\text { GLDS Test }\end{array}$ & $\mathrm{ADF}$ & Result \\
\hline \multicolumn{7}{|c|}{ Without structural break } \\
\hline Beef Ground Meat & Female Beef Cattle & $\mathrm{r}=1 * *$ & $0-12$ & no & no & no \\
\hline Beef Ground Meat & Milk Powder & $r=0$ & $0-17$ & no & no & no \\
\hline Beef Ground Meat & Fluid Milk & $\mathrm{r}=1 * *$ & $0-19$ & no - yes*** & no-yes* & yes \\
\hline Female Beef Cattle & Milk Powder & $\mathrm{r}=0$ & $1-16$ & no - yes $* *$ & no & no \\
\hline Female Beef Cattle & Fluid Milk & $r=1 * *$ & $0-12$ & no-yes $* * *$ & no - yes* & yes \\
\hline Beef Ground Meat & Female Beef Cattle \& Fluid Milk & $\mathrm{r}=1 * * *$ & $0-12$ & no & no & no \\
\hline Beef Ground Meat & Female Beef Cattle \& Milk Powder & $r=0$ & $0-12$ & no-yes** & no & no \\
\hline \multicolumn{7}{|c|}{ With a structural break } \\
\hline Beef Ground Meat & Female Beef Cattle & $\mathrm{r}=1 * * *$ & $0-3$ & yes** & yes* - yes** & yes \\
\hline Beef Ground Meat & Milk Powder & $\mathrm{r}=1 * * *$ & $0-13$ & no - yes** & no & yes \\
\hline Beef Ground Meat & Fluid Milk & $\mathrm{r}=1 * * *$ & $0-13$ & no-yes* & no & yes \\
\hline Female Beef Cattle & Milk Powder & $r=0$ & $0-2-7$ & yes* - no-yes* & no & no \\
\hline Female Beef Cattle & Fluid Milk & $\mathrm{r}=1 * *$ & $0-2$ & no & no & no \\
\hline Beef Ground Meat & Female Beef Cattle \& Fluid Milk & $\mathrm{r}=1 * * *$ & $0-8$ & no & yes**-no & yes \\
\hline Beef Ground Meat & Female Beef Cattle \& Milk Powder & $\mathrm{r}=1 * * *$ & $0-8$ & no & yes**- no & yes \\
\hline
\end{tabular}

$\uparrow \mathrm{r}=$ Cointegration range

$\dagger \dagger$ When each lag presents a different solution, there is more than one result for the same test. Yes=Evidence of cointegration. No=no evidence of cointegration.

$* * *$ means significance difference $\mathrm{P}<0.01, * * 0.05, * 0.10$

Source: Author's Elaboration.

Table 3.4 displays the results of the ECM which included the ECT from the long run equation with structural breaks. The $\alpha_{\mathrm{y}}$ is significant and negative in all cases, meaning that the adjustment toward the equilibrium is done by $P^{y}$, then market $\mathrm{x}$ influences market $\mathrm{y}$. Based on that, the following results are as expected:

- Milk powder affects the female beef cattle prices and not vice versa,

- Female beef cattle affects the beef ground meat market and not vice versa,

However, even if the relationship between beef ground meat and milk, the first one adjusted to deviations from the equilibrium as expected, the milk market also has a significant adjustment (Table 3.4). The latter behavior is unexpected since Dos Pinos is the one which defines the path of the milk price. Nevertheless, the fact that Dos Pinos determines the milk price taking the costs of production into consideration, which are affected by costs of keeping a cow, could explain the significant adjustment.

Another not expected result is the significant adjustment of fluid milk in its relationship with the female cattle market which can be explained by the same considerations presented before. However, it 
is worthwhile to stress that the milk powder does not have, unlike the fluid milk market, a significant adjustment. Therefore, although throughout the analysis the dissimilarities between these two markets have not been considered, in view of the differences of the results, especially in the relationship with the livestock market, future research which addresses this issue directly is suggested.

Recalling the weak evidence of cointegration from Table 3.3 and given the significant signs o $\alpha_{y}$ and $\alpha_{x}$ (Table 3.4) also in the relationships between female beef cattle and milk markets, we can say that the inclusion of the lagged structure in the analysis, which is con continued until the short run analysis or ECM, is relevant for unveiling the integration relationship between these two markets.

It is worthy to note that in agreement with the autocorrelation indicator (fourth column, Table 3.4), the errors of the ECM equations ( $\varepsilon_{i t}$ in equation 3 ) do not present signs of autocorrelation. Equally important, the skewness test (fifth column, Table 3.4) shows that only in the equations of $P^{x}$ there are signs of non-normality of the errors.

The Likelihood Ratio test was used in order to analyze asymmetric behavior; however, the null hypothesis stating that the coefficients of the ECT+ are equal to the coefficients of the ECT- cannot be rejected for any equation.

Table 3. 4

Results of the ECM with the ECT from the Long Run Equation with Structural Break

\begin{tabular}{|c|c|c|c|c|c|c|c|}
\hline \multirow[b]{2}{*}{ Relation $\dagger$} & \multirow[b]{2}{*}{$\begin{array}{c}\text { Dependent Variable } \\
\text { ECM }\end{array}$} & \multicolumn{3}{|c|}{ Without Asymmetric } & \multicolumn{3}{|c|}{ With Asymmetric } \\
\hline & & $\alpha$ & $\begin{array}{c}\text { No } \\
\text { Autocorrelation } \\
+\dagger\end{array}$ & $\begin{array}{c}\text { Normality } \\
\text { Errors } \dagger \dagger\end{array}$ & $\alpha^{+}$ & $\alpha^{-}$ & $\begin{array}{l}\text { LR test } \dagger^{+} \\
\mathrm{H}_{0:} \alpha^{+}=\alpha^{-}\end{array}$ \\
\hline \multirow{2}{*}{$\begin{array}{l}\text { Beef Ground Meat vrs } \\
\text { Female Cattle }\end{array}$} & Beef Ground Meat & $-0.19 * *$ & 0.75 & 0.17 & -0.77 & $-0.17 * * *$ & \multirow{2}{*}{0.66} \\
\hline & Female Cattle & -0.01 & 0.72 & 0.99 & 0.00 & -0.03 & \\
\hline \multirow{2}{*}{$\begin{array}{l}\text { Beef Ground Meat vrs } \\
\text { Milk Powder }\end{array}$} & Beef Ground Meat & $-0.05 * * *$ & 0.08 & 0.22 & -0.01 & $-0.85 * *$ & \multirow{2}{*}{0.25} \\
\hline & Milk Powder & $0.05^{*}$ & 0.41 & 0.00 & 0.01 & 0.09 & \\
\hline \multirow{2}{*}{$\begin{array}{l}\text { Beef Ground Meat vrs } \\
\text { Fluid milk }\end{array}$} & Beef Ground Meat & $-0.06 * * *$ & 0.20 & 0.28 & 0.00 & $-0.12 * * *$ & \multirow{2}{*}{0.16} \\
\hline & Fluid Milk & $0.07 *$ & 0.74 & 0.00 & 0.02 & $0.13^{*}$ & \\
\hline \multirow{2}{*}{$\begin{array}{l}\text { Female Cattle vrs } \\
\text { Milk Powder }\end{array}$} & Female Cattle & $-0.10 * * *$ & 0.55 & 0.25 & -0.06 & $-0.16 * * *$ & \multirow{2}{*}{0.32} \\
\hline & Milk Powder & 0.04 & 0.16 & 0.00 & 0.02 & 0.07 & \\
\hline \multirow{2}{*}{$\begin{array}{l}\text { Female Cattle vrs } \\
\text { Fluid Milk }\end{array}$} & Female Cattle & $-0.08 * * *$ & 0.39 & 0.19 & -0.05 & $-0.13^{* *}$ & \multirow{2}{*}{0.53} \\
\hline & Fluid Milk & $0.06 * *$ & 0.94 & 0.00 & 0.06 & 0.07 & \\
\hline \multirow{3}{*}{$\begin{array}{l}\text { Beef Ground Meat vrs } \\
\text { Female Cattle and Fluid Milk }\end{array}$} & Beef Ground Meat & $-0.12 * * *$ & 0.25 & 0.91 & -0.12 & $-0.12 *$ & \multirow{3}{*}{0.06} \\
\hline & Female Cattle & 0.06 & 0.12 & 0.66 & 0.08 & 0.05 & \\
\hline & Fluid Milk & 0.01 & 0.60 & 0.00 & $-0.32 * *$ & 0.25 & \\
\hline \multirow{3}{*}{$\begin{array}{l}\text { Beef Ground Meat vrs } \\
\text { Female Cattle and Milk } \\
\text { Powder }\end{array}$} & Beef Ground Meat & $-0.10 * * *$ & 0.59 & 0.92 & -0.12 & $-0.09 *$ & \multirow{3}{*}{0.75} \\
\hline & Female Cattle & 0.02 & 0.24 & 0.81 & 0.01 & 0.30 & \\
\hline & Milk Powder & $0.11 *$ & 0.43 & 0.00 & -0.03 & $0.19 * *$ & \\
\hline
\end{tabular}

$\uparrow$ The first one corresponds to $P^{Y}$ and the remaining prices to $P^{x}$.

$\dagger \dagger$ p-value.

Source: Author's Elaboration. 


\subsection{Conclusions}

Rather than only considering the vertical price transmission as a relationship between two markets of the same production chain, another kind of relationship which has not been deeply investigated is looked at: joint products. These are the products which are produced in a single production process, but do not correspond to the same chain. A special case is the beef and milk markets of Costa Rica. Even if these products usually correspond to disconnected chains, in Costa Rica farms make use of cattle to produce both meat and milk.

Price transmission between each market pair was found. Nevertheless, in opposition to the expected behavior, the relationship between the markets of milk and beef cattle show weak signs of cointegration. However, ECM results indicate that milk affects the female beef cattle price; it is shown that the short run structure of the relation is essential for identifying the integration between these markets. This could be related to the step shape of the milk price series (Figure 3.4) caused by the huge influence of Dos Pinos in the price behavior.

The price adjustment is consistent with the expected behavior. The cattle price is the only one which adjusts in the milk powder- female beef cattle relationship. This is linked with the power of Dos Pinos, the main milk cooperative, in defining the prices. However, in the relationship with beef cattle, fluid milk also has a significant adjustment. It is recommended that more research should be carried out in order to explore the differences between the fluid milk and milk powder markets. In addition, the market for female beef cattle affects the beef ground market and not vice versa.

Moreover, in the relationships among beef ground meat and both milk markets, beef ground meat as well as milk markets have significant adjustments. This could be explained by the fact that Dos Pinos takes the costs of production which are affected by costs of keeping a cow into consideration in its company's pricing policy. The latest has also an effect on the beef ground meat market.

The results of the asymmetric analysis are not as expected. The coefficients of both adjustments, i.e., to positive and to negative deviations from the long-run relation, are not significantly different.

The estimation allowing for structural breaks affects the results. First off, after the break the elasticities become higher than 1. Secondly, there is more evidence of cointegration. Lastly, the adjustment coefficients are significant only when a change in the long run is allowed for.

In order to achieve further insights into the analyzed relationships the livestock prices from the Costa Rican auctions throughout the country should be included. Such prices better reflect the behavior of small farmers which include a large number of double intention farms. Unfortunately, the data were not available for the whole period analyzed at the moment of this research. 


\subsection{References}

Barquero, M.; (2001). “Dos Pinos Limita la Competencia”. La Nación, San José, Costa Rica.

Barquero, M.; (2007). “Dos Pinos Prepara Ajuste Fuerte: Precio de Maíz y Petróleo Impulsa Alza en la Leche”. La Nacion, San José, Costa Rica.

Bertsch,F. ; (2006). "El Recurso Tierra en Costa Rica”. Agronomía Costarricense, 30 pp 133-156.

Cámara de Productores de Leche (CPL); (2007). "Bases de datos". San José, Costa Rica. (www.proleche.com/info_sector.htm).

Corporacion Ganadera; (CORFOGA); (2001). “Análisis del Censo Ganadero 2000”. San José, Costa Rica. (www.corfoga.org/pdf/proyecto/censo2000.pdf).

a. Corporacion Ganadera (CORFOGA); (2001). "Estudio de Mercado Hábitos de Consumo de Carne". (www.mag.go.cr/biblioteca_virtual_animal/habitos_consumo_carne.pdf).

Corporacion Ganadera (CORFOGA); (2003). "Ticos Prefieren Carne Molida”. Revista CORFOGA, Num V/I Sem.

Corporacion Ganadera (CORFOGA); (2005). “Costa Rica Bovine Cattle Sector Diagnosis". Working Document 2. (www.corfoga.org/pdf/estadist/DiagnosticodelSector2004_Ingles.pdf).

Engle, R.F., \& C.W.J. Granger; (1987). "Cointegration and Error Correction: Representation Estimation and Testing”. Econometrica, 55 pp 251-276.

Fallas, H.; (2007). “Caja de Leche Aumentará £25 a Partir del Lunes”. La Nacion, San José, Costa Rica.

Fallas, H.; (2008). “Dos Pinos Subió Precios. Litro de Leche Aumenta £30 más Desde Hoy”, La Nación, San José, Costa Rica.

Frey, G., \& M. Manera; (2007). "Econometric Models of Asymmetric Price Transmission”. Journal of Economic Surveys, 21(2) pp 349-415.

Gardner, B.; (1987). "The Economics of Agricultural Polices”. Washington D.C., USA. UNT Digital Library. pp 116-137. (http://digital.library.unt.edu/ark:/67531/metacrs21/)

Granger, C.W.J., \& T.H. Lee; (1989). "Investigation of Production, Sales and Inventory Relationships Using Multicointegration and Non-Symmetric Error Correction Models”. Journal of Applied Econometrics, 4 pp 145-159.

Gregory, A.W., \& B.E. Hansen; (1996). "Residual Based Tests for Cointegration in Models with Regime Shifts". Journal of Econometrics, 70(1) pp 99-126.

Holmann, F., R. Libardo, E. Pérez, et al.; (2007). "La Cadena de Carne Bovina en Costa Rica: Identificación de Temas Críticos para Impulsar su Modernización, Eficiencia y Competitividad, International Livestock”. Research Institute (ILRI), Centro Internacional de Agrícultura Tropial (CIAT), Corporación Ganadera (CORFOGA). (http://www.corfoga.org/images/public/documentos/pdf/cadena_carne_bovina_CR.pdf).

International Monetary Fund (IMF); (Consulted November 2008). "Data and statistics". (www.imf.org/external/data.htm\#data).

Johansen, S.; (1995). "Likelihood-based Inference in Cointegrated Vector Autoregressive Models". Oxford University Press, Oxford.

Kirchgässner, G., \& Wolters J.; (2007). “Introduction to Modern Time Series Analysis”. Springer. Berlin, Germany.

Kwiatkowski, D., P. Phillips, P. Schmidt, \& Y. Shin; (1992). "Testing the Null Hypothesis of Stationarity against the Alternative of a Unit Root". Journal of Econometrics, 54 pp 159-178. 
Lanne, M., H. Lütkepohl, \& P Saikkonen; (2003). "Test Procedures for Unit Roots in Time Series with Level Shifts an Unknown Time". Oxford Bulletin of Economics and Statistic.

Leitón, P.; (2002). “Litro de Leche Subió £12”. La Nacion, San José, Costa Rica.

Leitón, P.; (2005). “Mercado Externo De Carne Impacta Precios Locales”. La Nacion, San José, Costa Rica.

Ministry of Agriculture and Livestock (MAG); (2006). "Boletin Estadístico del Sector Agropecuario". San José, Costa Rica. 8www.mag.go.cr/bibliotecavirtual/index.html).

Quirós, E.; (2006). "Historia de la Ganaderia Bovina en Costa Rica”. CORFOGA, Corporacion Ganadera. San José, Costa Rica.

Quiros, R. (ed.); (2006). "Resumen de la Conferencia: Financiamiento de las Cadenas Agricolas de Valor”. San José, Costa Rica. ISBN: 9977-21-073-5

Rapsomanikis, G., D. Hallam \& P. Conforti (2003). "Market Integration and Price Transmission in Selected Food and Cash Crop Markets of Developing Countries: Review and Applications”, in Commodity Market Review 2003-2004, FAO, Rome, 2003.

Rojas, J.E.; (2005). "Ventas Caen Hasta 20\% En Carnicerías Ganaderos: "Normal" Alza en la Carne”. La Nacion, San José, Costa Rica.

Saikkonen, P., \& H. Lütkepohl; (2002). "Testing for a Unit Root in a Time Series with a Level Shift at Unknown Time". Econometric Theory, 18(2) pp 313-348.

United States Department of Agriculture (USDA); (Consulted November 2008). "Feed grand data base". (www.ers.usda.gov/Data/Feedgrains/).

von Cramon-Taubadel, S., \& J. Meyer; (2004). “Asymmetric Price Transmission: A Survey”. Journal of Agricultural Economics, 55 pp 581-611.

Zhang, D., D. Dickinson, \& M. Barassi; (2006). "Structural breaks, Cointegration and B Share Discount in Chinese Stock Market”. paper presented at the Ecomod.net International conference of Policy Modelling, Hong Kong.

Zheng, S., D. Miller, Z. Wang, \& S. Kai; (2008). "Meta Evidence of Asymmetric Price Transmission in the US Agricultural Markets”. Journal Faculty of Agriculture Kyushu University, 53(1) pp 349-356. 


\section{Annex 3.1}

Stability Analysis of the Long Run Equation: Cusum and Cusum Square.

Figure 3.6

Beef Ground Meat and Female Beef Cattle

A. Cus UM

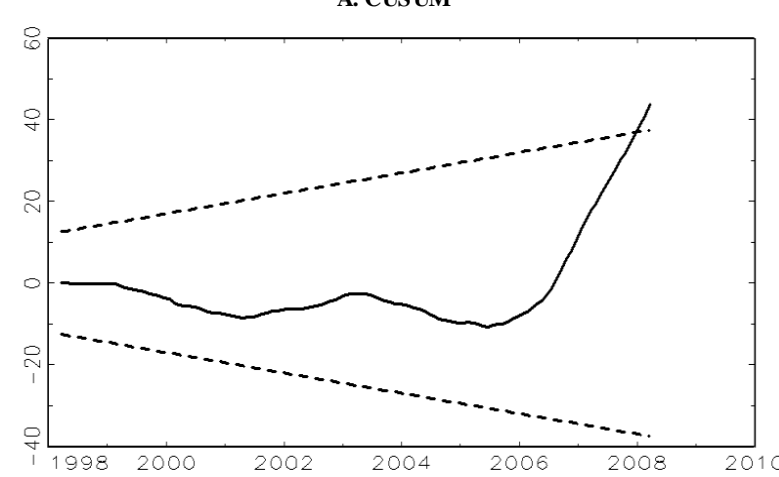

Source: Author's Elaboration.

Figure 3.7

Beef Ground Meat and Milk Powder
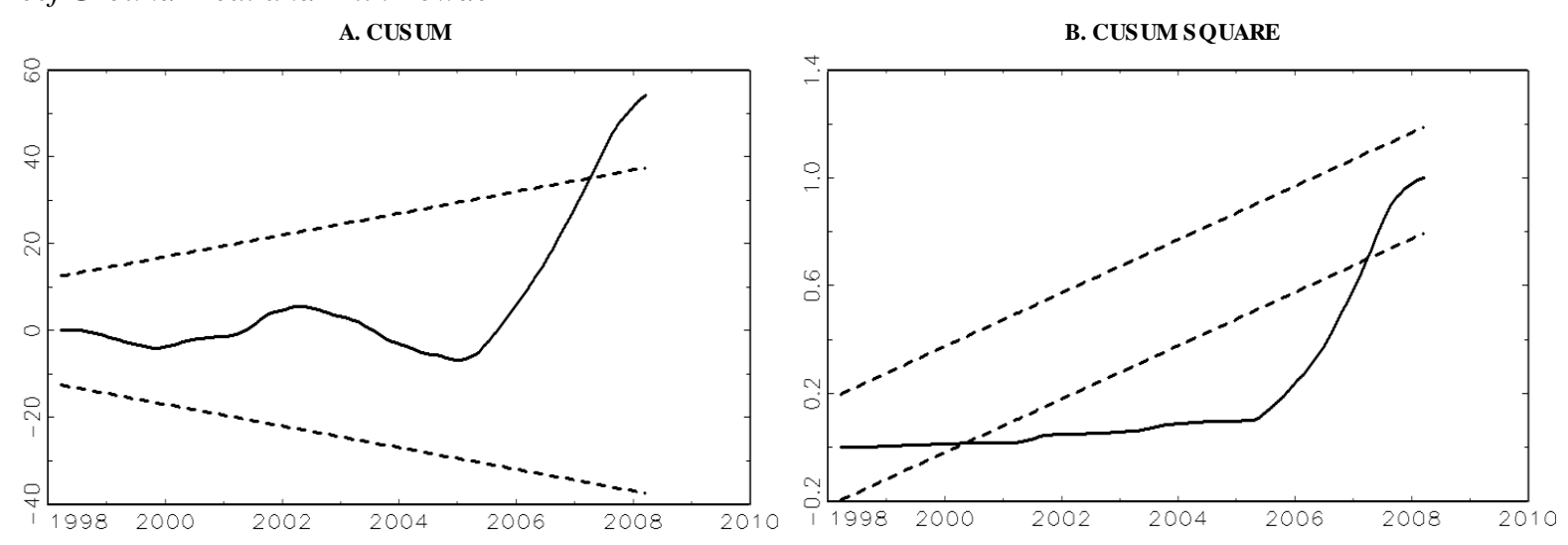

Source: Author's Elaboration.

Figure 3.8

Beef Ground Meat and Fluid Milk
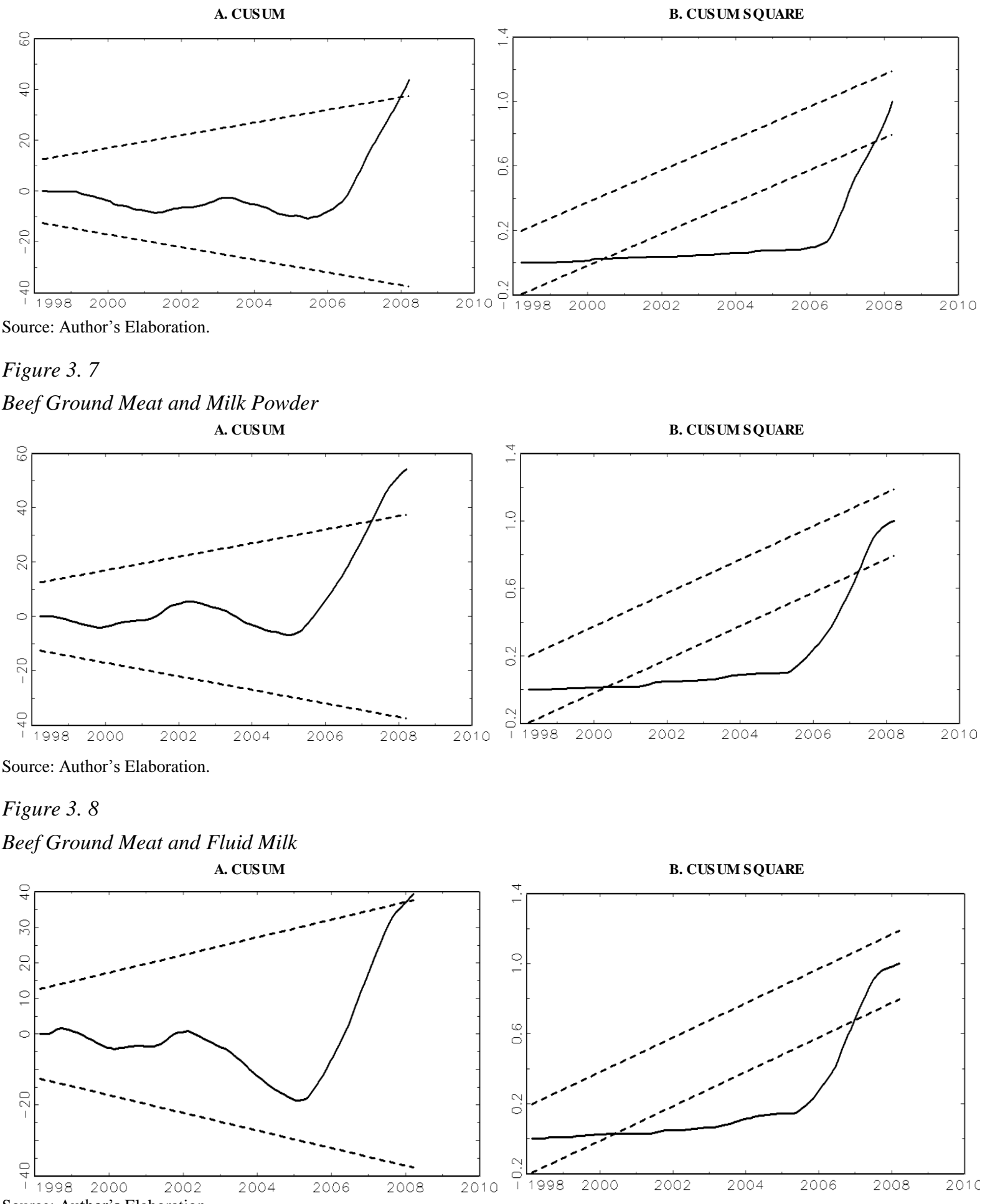

Source: Author's Elaboration.

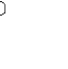


Figure 3. 9

Female Beef Cattle and Milk Powder
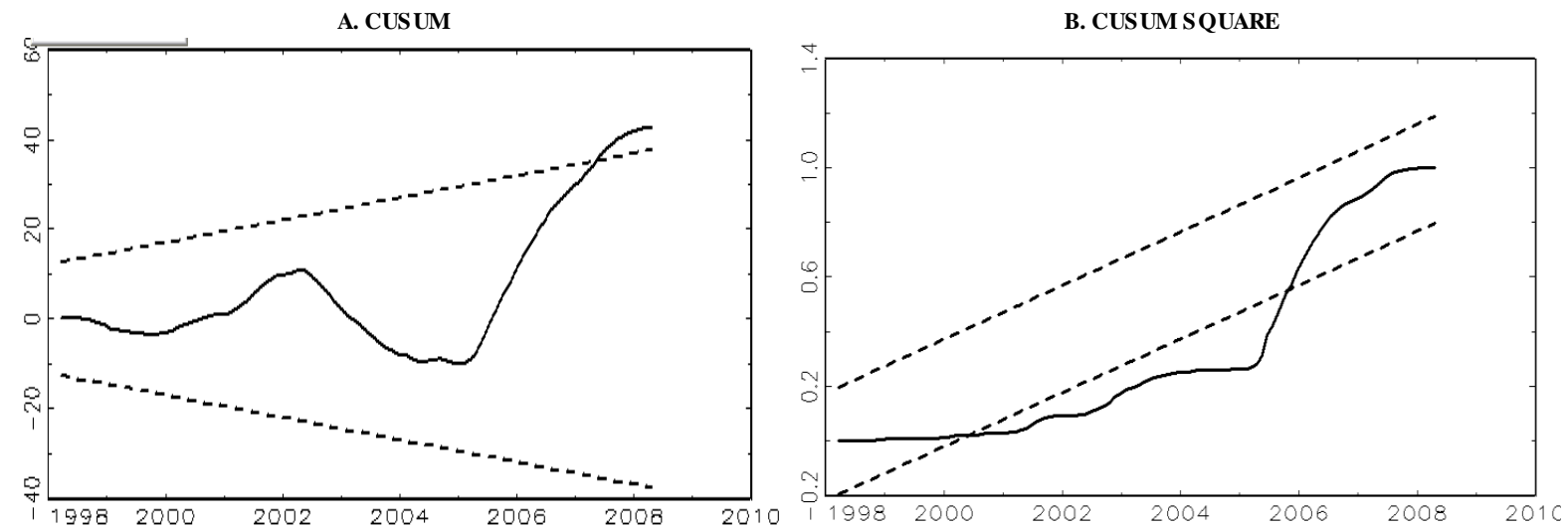

Source: Author's Elaboration.

Figure 3. 10

Female Beef Cattle and Fluid Milk

A. CUSUM

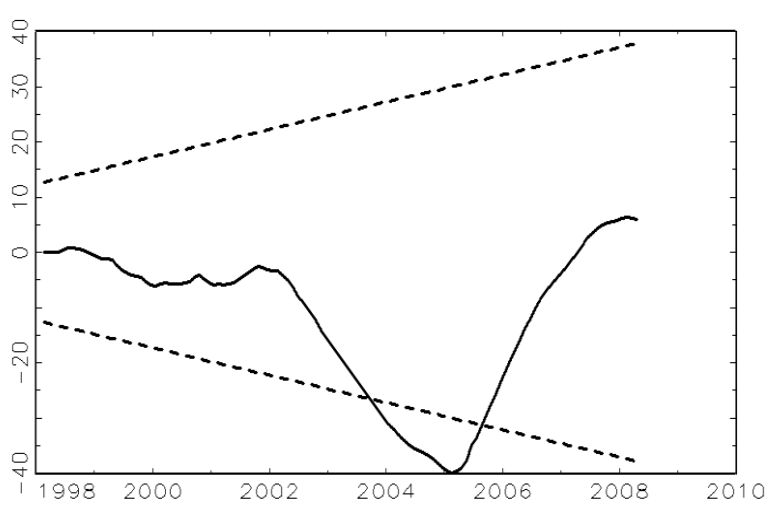

B. CUSUM SQUARE

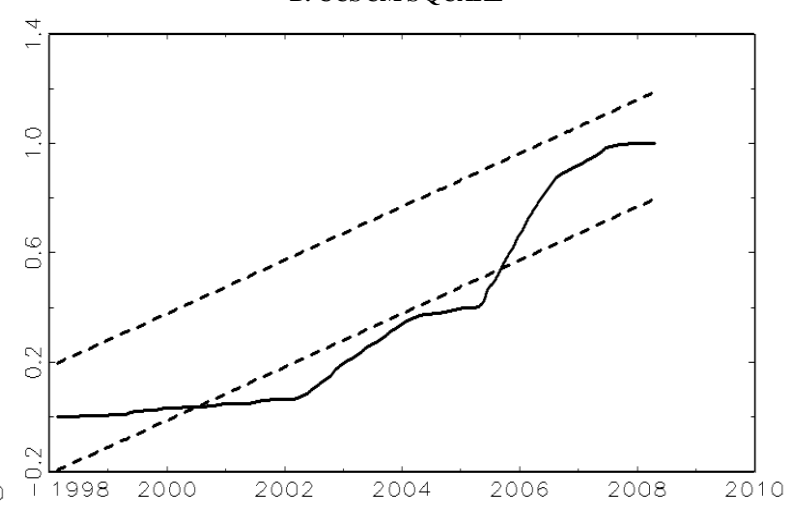

Source: Author's Elaboration

Figure 3. 11

Beef Ground Meat, Female Beef Cattle and Fluid Milk

A. CUSUM

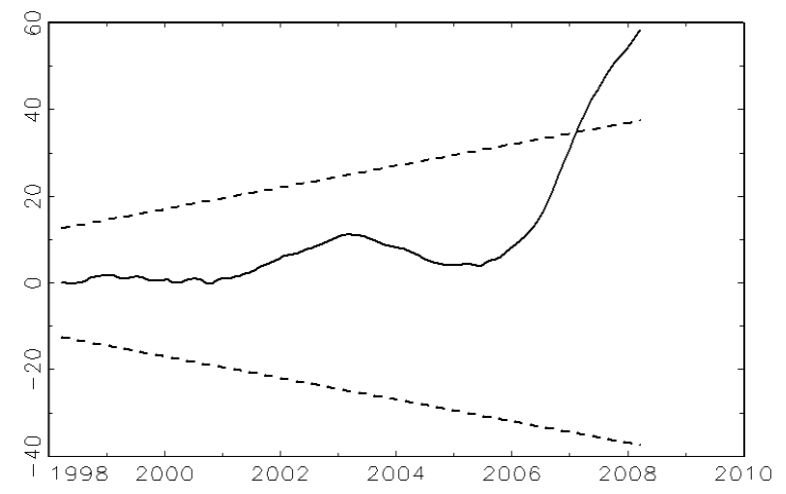

B. CUSUM SQUARE

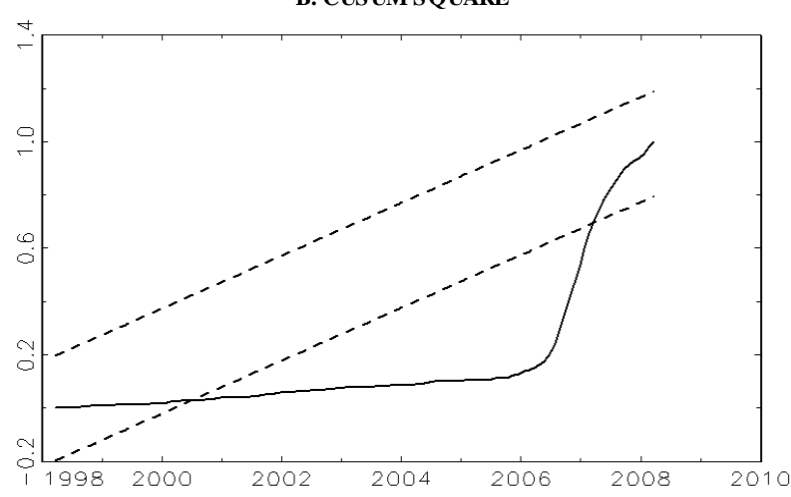

Source: Author's Elaboration. 
Figure 3. 12

Beef Ground Meat, Female Beef Cattle and Milk Powder
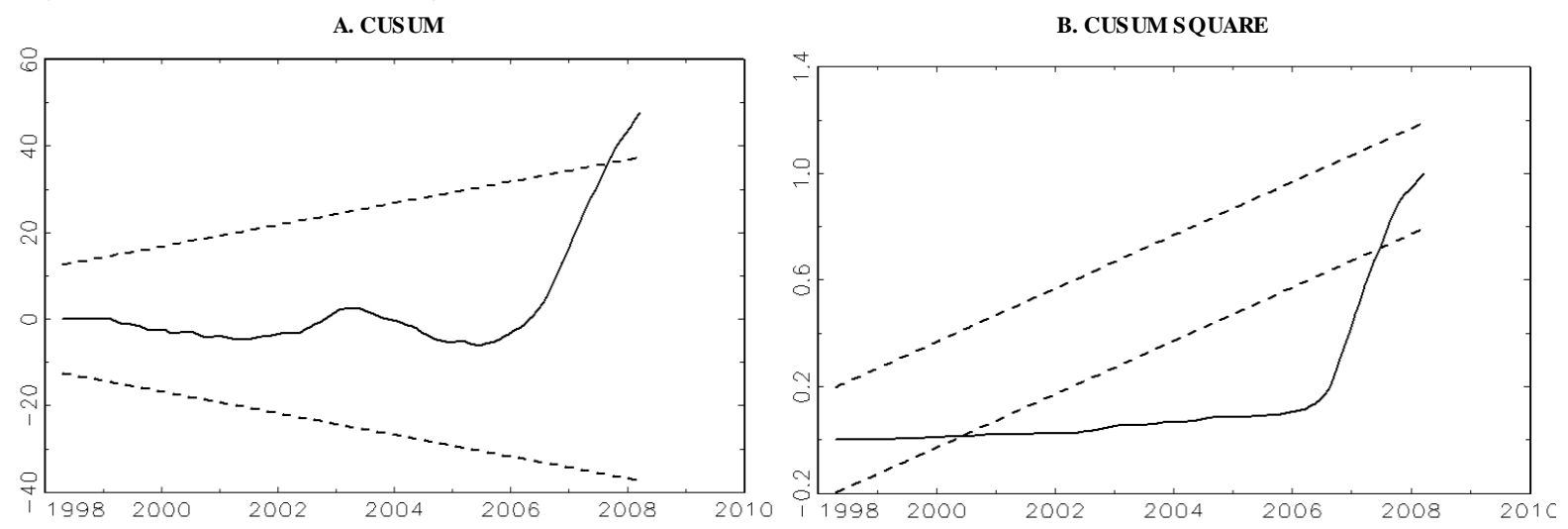

Source: Author's Elaboration. 


\section{Chapter 4}

\section{Price Transmission in Latin American Maize and Rice Markets}

\subsection{Introduction}

The boom and subsequent decrease in food prices that took place around 2008 have raised numerous questions about the impact of such variations on populations' welfare and on the economic sector which directly concerns the agricultural sector, while not to mention there is no guarantee that prices will not raise again once the financial crisis is over. In this matter, if governments are to take adequate measures to ensure food security, they need to have good knowledge of the functioning of their markets. This implies, among others, knowing the state of price transmission along the marketing chain within the country and between international and domestic markets.

Price transmission is important for two main reasons. First, because price transmission conveys unbiased information on prices to agricultural producers, it is a prerequisite for a good allocation of resources. Incomplete price transmission creates biased incentives to producers, which in turns leads to suboptimal decision-takings and reduced agricultural productivity. Secondly, because many policy reforms are implemented through the price channels (e.g. tariffs), a lack of integration along the marketing chain prevents reforms from reaching the first partakers of the chain, agricultural producers in particular.

Moreover, in the case where it is asymmetric, price transmission can worsen income inequalities inside a country. Transmission is said to be symmetric if the price response to a variation in another price along the marketing chain is independent from the direction of the change of the latter. In the case of asymmetry, part of the benefits of a change in the international price is reaped off by stakeholders higher up in the marketing chain and only a small part of it is passed on to the final partakers of the chain (producers or consumers), leading to an inequality in the distribution of incomes (Meyer \& von Cramon-Taubadel, 2004).

In the context of economic openness and international trade, completeness of price transmission allows agricultural producers to become competitive at the international level. On a more global level, this stimulates economic development and helps to alleviate poverty and inequalities.

Few papers analyze price transmission in Latin America and even less so in Central America. Mundlak and Larson (1992) used the Law of One Price to test if variations in world prices are reflected in domestic prices and to what extent. They worked on more than 60 Latin America 
countries, including Brazil, Chile, Costa Rica, El Salvador, Guatemala and Panama. They found that in general, variation in world prices represent a large part of the variation in domestic prices. In the same vein, Conforti (2004) analyzed price transmission in Latin America (Brazil, Chile, Costa Rica, Mexico and Uruguay), Africa and Asia. They identified three common variables to all countries: (i) geographical regularity: price transmission is low in Africa, the evidence is mixed in Latin America and it is more complete in Asia; (ii) intra-country price transmission seems to be stronger than intercountry; (iii) grains show a higher level of market integration than other agricultural products. Baffes and Gardner (2003) studied price transmission in the context of policy reforms of openness in Chile, Mexico, Argentina, Colombia, Madagascar, Ghana, Indonesia and Egypt. Evidence of integration was mixed in Latin America and reforms had an impact on price transmission only in Argentina and Mexico. Other papers concentrate their analysis on one country, especially on Chile and Brazil, probably because of the availability of data. For example, Díaz et al. (2007), Díaz and Melo (2007) and Engler and Nahuelhual (2008) worked on the dairy sector in Chile. Margarido and Lima (2009) and Anguiar and Santana (2002) studied price transmission of farm prices in Brazil. Finally, Escobal and Vásquez (2008) looked at the impact of infrastructure on the quality of price transmission in the potato market in Peru.

This paper analyzes price transmission in maize and rice markets in various Latin American countries (Brazil, Chile, Costa Rica, Guatemala, El Salvador, Nicaragua, Panama and Honduras), most of which belong to Central America. Using cointegration methods and error correction models, the level of price transmission from international prices towards local wholesale prices (intermediaries' reselling prices) and/or producers' prices (that is, the price paid to the farmer by the intermediary or transporter for example) is evaluated. In a second step, asymmetric price transmission is tested for.

The two markets analyzed - maize and rice - were chosen due to their common characteristics of special interest: (i) they are commodities and hence homogeneous, which makes their comparison across markets and countries easier; ii) for both of the commodities, international prices escalated in recent years; (iii) they are staple crops, i.e., have an important role in food security; rice represents $80 \%$ of the daily food intake for more than $40 \%$ of the world population (Benavides \& Segura, 2005) and more than $10 \%$ of calories consumed are attributed to maize in 42 countries (FAO, 2009). The relevance of maize and rice in the consumption patterns of the countries included in the investigation varies. For instance, while in Costa Rica rice is a main staple quite more important than maize, in Honduras, Guatemala and El Salvador the situation is the opposite. In order to more clearly view these differences Table 4.1 displays the importance of each product within the total energy consumption in the different countries. 
Table 4. 1

Share of Rice and Maize in Total Energy Consumption (kcal/per-capita/day)

(Average 2003-2005)

\begin{tabular}{lcc}
\hline Country & Rice $(\%)$ & Maize $(\%)$ \\
\hline Brazil & 13.0 & 6.8 \\
Chile & 2.6 & 5.4 \\
Costa Rica & 17.4 & 4.9 \\
El Salvador & 3.6 & 31.9 \\
Guatemala & 2.5 & 40.2 \\
Honduras & 5.5 & 28.6 \\
Nicaragua & 20.7 & 22.9 \\
Panamá & 24.8 & 6.5 \\
World & $\mathbf{1 9 . 2}$ & $\mathbf{4 . 9}$ \\
\hline
\end{tabular}

Source: FAO Statistical Yearbook 2007-2008

Several papers analyze price transmission in maize and rice markets. For example, Giorgetti et al. (2007) found evidence of cointegration between the international and national prices of maize in Argentina. Sarris and Mantsou (2005) analyzed the maize market in Tanzania by comparing the domestic price not only with USA prices (Tanzania imports mainly from the USA), but also with South African prices. They showed that the Tanzanian maize price is affected mainly by the South African price, illustrating that price transmission does not necessarily follow physical flows. Other papers that include maize in their analysis are Fiess and Ledermann (2004), Alemu and Biacuana (2006) and Abdulai (2000). It is also worth mentioning Cuéllar and Ramírez (2009) who investigated the effect of trade liberalization on the level of integration of the Central American and USA markets using the dynamic regression of Ravallion (1986) and the Self-Exciting Threshold AutoRegressive (SETAR) model. They concluded that none of the Central American countries were integrated with the USA market. As for the rice market, Goletti et al. (1995) used several measures of integration to estimate the level of price transmission in Bangladesh's rice market and found that price transmission is rather weak. Istiqomah et al. (2005) analyzed price transmission in the Indonesian rice market before and after market liberalization. Their results showed that integration was almost perfect between producers and consumers before the reform, but that it deteriorated after the reform.

Section 4.2 gives an overview of the concept of price transmission and of estimation methods that are used in this paper. Section 4.3 briefly describes the domestic markets studied and the state of international trade in the countries studied. The data used and their description is presented in Section 4.4, the hypothesis in Section 4.5 and the results are given in Section 4.6. Section 4.7 concludes.

\subsection{Price Transmission and Asymmetric Price Transmission}

Price transmission can be defined as the relationship of interdependency between prices in two related markets, e.g. between the international and domestic prices of a commodity or between the producer and consumer prices of a consumption good. This principle has its roots in the Law of One Price, 
which states that the difference in prices between two spatially distant markets should not exceed the costs to transport the good from one market to the other. If this condition is satisfied, we say that the two markets are integrated, i.e, that price transmission between them is perfect. However, the mechanism that allows this condition to hold spatial arbitrage requires free, frictionless and perfect markets, which are rarely encountered in reality.

In fact, price transmission is usually incomplete and the reasons for that are manifold (Conforti, 2004):

Excessive transaction costs (e.g. transport costs, incomplete information, search of information, negotiation costs, costs associated with supervision and application of contracts): whenever transaction costs are disproportionate, the benefit of spatial arbitrage disappears and the Law of One Price cannot hold anymore.

Border policies (e.g. tariffs and non-tariff barriers, import quotas, export subsidies): by restraining international trade, border policies cut the price transmission channel from international to domestic markets.

Domestic policies (e.g. price intervention, minimum price, marketing board): impede price transmission along the marketing chain within the country.

Moreover, to be perfect, price transmission needs not only be complete, but it also has to be symmetric. The following three reasons can lead to an asymmetric price transmission (Conforti, 2004):

Market power: whenever there is market concentration in some part of the marketing chain, the ability of the power holder to influence the price unilaterally or in a collective way alters price transmission. For example, an oligopsony of wholesalers can decide to pass on a decrease in the international price to local producers, while it can delay this transmission in the case of an increase in the international price, hence retaining an additional margin.

Menu costs: the incentive to adjust prices (on a restaurant menu, for a straightforward example) is higher when the input prices increase than when they decrease, because a higher price allows covering at least part of the repricing costs (or reprinting of the restaurant menu). This leads to an asymmetric price adjustment and hence an asymmetric transmission.

Inventories: when the expected price is larger than today's price, inventory holders buy in large quantities today to sell it back in the future, hence making a profit. At a given due date, this additional supply lessens the expected increase in prices. When the expected price is lower (Conforti, 2004; Abdulai, 2000) than today's price, this inventory transaction does take place, however, allowing the price to indeed decrease in the future. This asymmetric intervention from inventory holders leads to an asymmetric realization of expectations and hence to asymmetric price transmission.

This paper makes use of cointegration methods and error correction models (ECM) to measure the strength and speed of price transmission. Cointegration represents the long run equilibrium relationship between two variables, allowing for temporary deviations from the equilibrium in the 
short run due to changes in one or both variables. For example, in the short run, consumption may be unrelated to the level of income, but in the long run, consumption represents a roughly constant part of it (Hamilton, 1994). The relationship of cointegration between the two is the same as described in the last chapter in (3.1). This tendency towards the equilibrium, that is, the short term relationship between the two variables, is represented by the error correction model also described in Chapter 3 in equations (3.3.1) and (3.3.2).

Of particular interest in this case is parameter $\alpha_{\mathrm{i}}$, which represents the percentage change in the dependent variable $\mathrm{i}(\mathrm{i}=\mathrm{x}, \mathrm{y})$ in response to past deviation from the equilibrium $\mathrm{ECT}_{\mathrm{t}-1}$. This parameter has an important characteristic; the absolute value of the net adjustment $\left(\operatorname{ABS}\left(\alpha_{y}-\alpha_{x}\right)\right)$ should be as close as possible to 1 since it represents the adjustment speed of $P_{t}^{i}$ to deviations from the equilibrium (1 hence represents an immediate adjustment).

Asymmetric price transmission is analyzed following for the work developed by von CramonTaubadel (1998) which used the modification of cointegration analysis suggested by Granger and Lee (1989), (see also Meyer \& von Cramon-Taubadel, 2004; Frey \& Manera, 2007). The ECM is rewritten as:

$$
\begin{aligned}
& \Delta P_{t}^{y}=\alpha_{y}^{+} E C T_{t-1}^{+}+\alpha_{y}^{-} E C T_{t-1}^{-}+\sum_{j=1}^{n_{x}} \Gamma_{j}^{y} \Delta P_{t-j}^{y}+\sum_{j=1}^{n_{y}} \Gamma_{j}^{x} \Delta P_{i-j}^{x}+\delta_{i} D_{i}+\varepsilon_{t}^{y} \\
& \Delta P_{t}^{x}=\alpha_{x}^{+} E C T_{t-1}^{+}+\alpha_{x}^{-} E C T_{t-1}^{-}+\sum_{j=1}^{m_{x}} \Phi_{j}^{y} \Delta P_{t-j}^{y}+\sum_{j=1}^{m_{y}} \Phi_{j}^{x} \Delta P_{t-j}^{x}+\delta_{i} D_{i}+\varepsilon_{t}^{x}
\end{aligned}
$$

to capture the asymmetric effect. In this equation, $E C T_{t-1}^{+}$are the positive deviations from equilibrium (when $E C T_{t-1} \geq 0$ ) and $E C T_{t-1}^{-}$represents the negative ones. There is asymmetry in price transmission whenever both $\alpha_{i} \quad(\mathrm{i}=\mathrm{x}, \mathrm{y})$ are significant and $\alpha_{i}^{+}$is significantly different from $\alpha_{i}^{+}$which is tested using the Likelihood Ratio Test (LRtest). This would imply that adjustments to deviations from the long run equilibrium occur at different speeds depending on whether the deviation is positive or negative.

Finally, the analysis controls for the presence of structural breaks in the long term relationship, following the method proposed by Gregory and Hansen (1996). This method allows us to include a structural break in the constant of equation (3.1), as explained in Section 3.3. If the break is in the constant and the slope, the long term relationship is represented by $\beta_{1}^{1}$ before the break and by $\beta_{1}^{1}+\beta_{1}^{2}$ after the break (since $\beta_{1}^{2}$ is the coefficient of the interaction term). 


\subsection{The Latin American Agricultural Sector: Rice and Maize}

The countries analyzed in this paper Brazil, Chile, Costa Rica, Guatemala, El Salvador, Nicaragua, Panama and Honduras have followed a similar reform pattern since the beginning of the 1980s. Until the end of the 1970s, most of these countries were experiencing frequent government interventions in the agricultural sector. Policies were oriented towards food sufficiency, thus promoting the production of staple crops (Pingali, 2001). Local banks were offering subsidized rate credits, and governments often participated in the market, buying crops like maize and rice at fixed prices which were higher than the international price. At the same time, governments maintained their overvalued currencies, encouraging imports and discouraging exports. Moreover, import substitution and debt accumulation policies were undertaken, which finally led to a structural disequilibrium and an economic recession in the beginning of the 1980 s.

In response, the 1980s was a decade of large scale macroeconomic reforms, including reduction of consumption subsidies, real exchange rate devaluation and the adjustment of domestic prices towards equalization with international prices (Childs \& Burdett, 2000; Eberlin, 1998; Ekboir et al., 2003; Jansen et al., 2007). Finally, in the 1990s, governments undertook important reforms towards trade openness and regional integration (Sanint et al., 1998), in many instances induced by the World Bank. However, de Janvry et al. (1997) state that even if these reforms had a positive impact on the economy and succeeded in reducing fiscal deficit, controlling inflation and increasing external trade, they were far from being a real success. This is because, firstly, many of these reforms were incomplete and secondly, because some issues, such as an increase in income inequalities, were not dealt with. Nowadays, most of these countries follow their openness paths by lowering import tariffs and signing regional and bilateral trade agreements. The following table shows the evolution of import tariffs on rice and maize in the countries analyzed.

Table 4. 2

Import Tariffs

\begin{tabular}{lcccc|cccc}
\hline & \multicolumn{4}{c}{ RICE } & \multicolumn{4}{c}{ MAIZE } \\
& $1991-1995$ & $1996-2000$ & $2001-2005$ & $2006-2008$ & $1991-1995$ & $1996-2000$ & $2001-2005$ & $2006-2008$ \\
\hline Brazil & 7.9 & 7.0 & 6.1 & 1.1 & 8.8 & 9.1 & 7.4 & 2.4 \\
Chile & 22.0 & 10.7 & 5.7 & 1.6 & 14.7 & 10.3 & 6.1 & 1.9 \\
Costa Rica & & 12.8 & 16.0 & 11.7 & & 6.5 & 9.5 & 8.3 \\
El Salvador & 50.2 & 11.3 & 11.1 & & 10.3 & 8.3 & 6.7 \\
Guatemala & 18.8 & 20.0 & 5.9 & & 20.0 & 20.0 & 12.5 \\
Honduras & 5.8 & 0.3 & 11.3 & & 20.0 & 15.6 & 10.0 \\
Nicaragua & 12.0 & 16.9 & 13.5 & & 9.9 & 8.6 & 2.8 \\
Panamá & 40.0 & 56.3 & 48.0 & & 14.7 & 17.0 & 23.0 \\
\hline Source: Data TRAINS (COMTRADE) & & & & & & &
\end{tabular}

This table shows that tariffs of both maize and rice have decreased since the 1990s in Brazil and Chile to reach a very reasonable level. Countries of Central America also reduced their tariffs, but in a less regular way and to a lesser extent than Brazil and Chile, and Panama especially so. This reflects the 
fact that in Central America, maize and rice are still considered staple crops of importance for food security and hence have benefited from special exceptions in trade agreements.

Figure 4.1 shows the evolution of Brazil's and Chile's net export of maize and rice. We can see that overall Chile imports more rice and maize than it exports, i.e, that Chile is a net importer of these two products. This is also true for the rice market in Brazil. As for maize, Brazil went from being a net exporter to a net importer. However, on average, the latter prevails.

As we can see in Figure 4.2, Central American countries went from a situation of more or less selfsufficiency in maize in the 1970s and beginning of the 1980s to a position of net importers over the last two decades. The same evolution can be seen in the case of rice, with a lesser level of dependency however.

The structure of the maize and rice marketing chains, along with governmental policies, can greatly affect the level of price transmission between the international and domestic markets. The structure of the marketing chains observed in the analyzed countries can be categorized into three groups, from markets with the least agricultural producer protection to markets with the highest: (i) marketing chains with a high level of concentration at the industry level and little protection for the agricultural producers; (ii) markets that benefit from some kind of agreement between agricultural producers and the intermediaries, where various aspects of the transaction are agreed upon (determination of the price or of the buying time, for example); (iii) markets under a governmental price control system (minimum price, price band).

Chile (rice and maize), El Salvador (rice) and Guatemala (maize) belong to the first group. Nicaragua (rice) lays between the two first groups, since only a portion of the agricultural producers are part of an agreement with the industry, the rest of them being subject to the industry's market power. The rice markets in Panama and Guatemala fall in the second category, while Costa Rica (rice), Honduras (rice and maize) and Brazil (maize) fit into the last one. The maize market in Panama is a special case: on the one hand, producers are organized in associations and on the other hand, the government carries out a reconversion program from grains towards export products. 
Figure 4. 1

Brazil's and Chile's Net Exports (1000 ton)

A.Chile

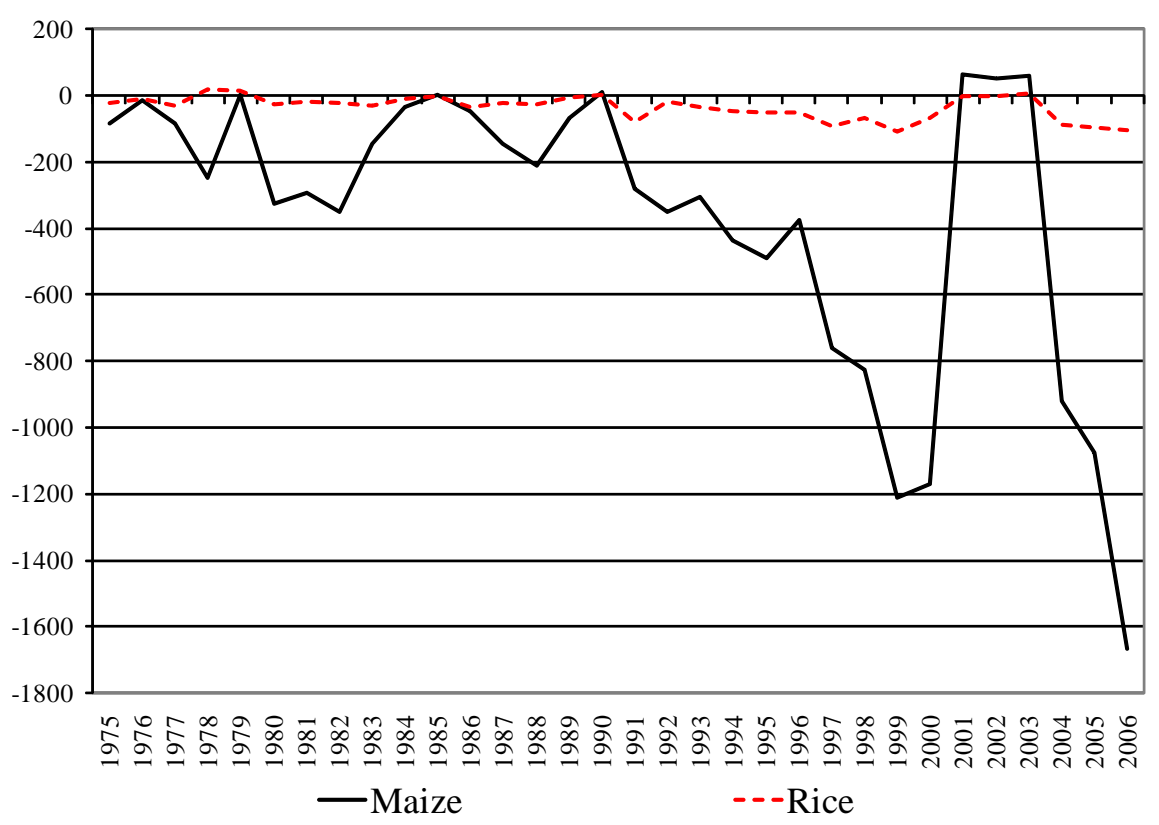

B. Brazil

Source: Data TRAINS (COMTRADE) 


\section{Figure 4. 2}

Central American Countries' Net Exports
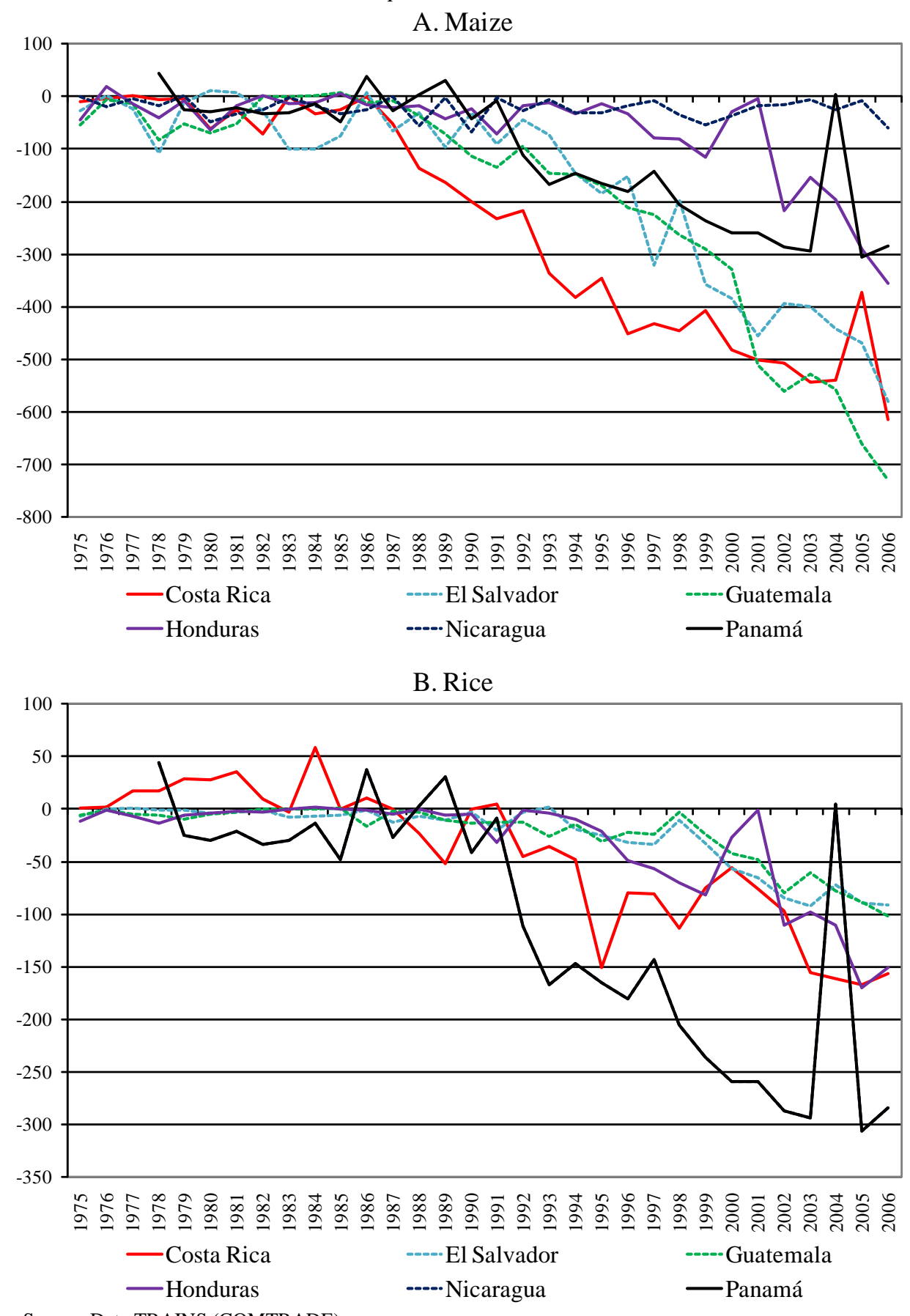

Source: Data TRAINS (COMTRADE)

\subsection{Data and Variables Description}

As said in the introduction, this paper analyzes price transmission on the one hand between international prices and domestic agricultural producer prices and, on the other hand, between international prices and domestic intermediary prices depending on the availability of domestic price data. We could also not study price transmission between the domestic intermediary and producer prices because both price data were not available for every country and, when they were, only in a few cases did both prices meet the econometric requirement of non-stationarity. 
The domestic maize and rice price data of the Central American countries comes from the Regional Council of Agricultural Cooperation (Consejo Regional de Cooperación Agrícola (CORECA)), except for Costa Rica, for which data was obtained from the "Informe Estadístico" published by CONARROZ (2008). In the case of Chile the data was available from the Office of Agricultural Studies and Policies (Oficina de Estudios y Políticas Agrarias (ODEPA)). Finally, Brazilian data was provided by the office of ECLAC in Brazil.

In every country, the type of rice considered for the producer price is paddy rice, that is, rice that has only been cut from the plant, with the husk, i.e, without any transformation. Milled rice, that is, rice without the husk and ready to consume, is considered for the intermediary price. As for maize, the type used is yellow maize for both producer and intermediary prices. It is important to note that yellow maize is commonly used as an animal foodstuff and more rarely for human consumption.

The international price used in the analysis is determined by the market from which the country imports most. Hence, in the case of rice, the Central American domestic prices are compared with the USA FOB (Gulf) price, since most (more than half) of their rice imports come from the USA (SIECA, 2009). As for Brazil, the international prices that matter most are the Argentinean and Uruguayan FOB prices. In the case of Chile, the domestic prices are compared to all three (USA, Argentinean and Uruguayan) prices. Finally, given that Thai prices are usually considered as the international reference price, price transmission is also estimated between all domestic prices and the Thai price.

In all countries, the domestic maize price is compared to the USA international price, since it is the main source of imports of the region (again, more than $60 \%$ of the imports come from the USA). In the case of Chile and Brazil, the analysis is extended to the Argentinean price (Chile/Brazil imports about $40 \% / 10 \%$ from the USA and about 30\%/30\% from Argentina).

The USA, Argentinean and Uruguayan rice FOB prices were made available by the USDA (United States Department of Agriculture) and Thai prices from the IMF (International Monetary Fund). However, in the case of maize, the USA and Argentinean prices were provided by the International Grain Council (IGC).

All prices are monthly data and are in dollars per ton. The time span changes with the internationaldomestic pair of prices considered, depending on the information available (Annex 4.1). The variables are used in their logarithmic form (allowing for the interpretation of coefficients as elasticities) and missing values are filled in using the econometric package AMELIA II, developed by Honaker et al. (2009).

Figures 4.4-4.11 in Annex 4.2 show the price data available in each country along with the international prices they are compared with. These graphs give a first idea of the degree of correlation, i.e., of the a priori level of price transmission between international and domestic prices. We can see that there is a strong visual evidence of correlation between international prices and the rice producer prices for Nicaragua (Figure 4.7), the maize intermediary prices for Chile (Figure 4.11) and both rice 
and maize prices for Brazil (Figure 4.10). Prices in Guatemala also seem to be related with international prices, though less strongly (Figure 4.5). In the rest of the countries analyzed, there is no real evidence of the existence of price transmission. This however does not mean that a relationship does not exist, which is what the econometric analysis will depict. Figure 4.9 highlights the "steps" aspect of Costa Rican rice prices which reflects the government's price fixing policy.

Finally, we can see that the boom in prices goes up in almost all of the domestic and international price series.

\subsection{Hypothesis}

In this section, the hypothesis concerning the functioning of price transmission is elaborated on the basis of the descriptions of rice and maize markets for each country. This is not a theory of price transmission, but simply working assumptions.

As explained before, price transmission from international prices to intermediary prices (that is, the intermediaries' reselling price to wholesalers) and to producer prices (i.e., the price at which the farmer sells its product) is analyzed. As the short description of rice and maize marketing chains in the countries analyzed shows (see Section 4.3), it cannot be assumed that the way price transmission takes place from the international price and along the marketing chain is similar in all markets. However, general features can be outlined.

In general, intermediaries in maize and rice markets have two possible sources to buy the primary product (that is without much transformation): from the farmer or they can import it. Once its transformation is completed, intermediaries sell the processed product to wholesalers or sometimes directly to consumers. As for wholesalers, they can buy the final product from intermediaries or import it. These physical flows are depicted in solid arrows in the following figure.

Figure 4. 3

Representation of Marketing Chains

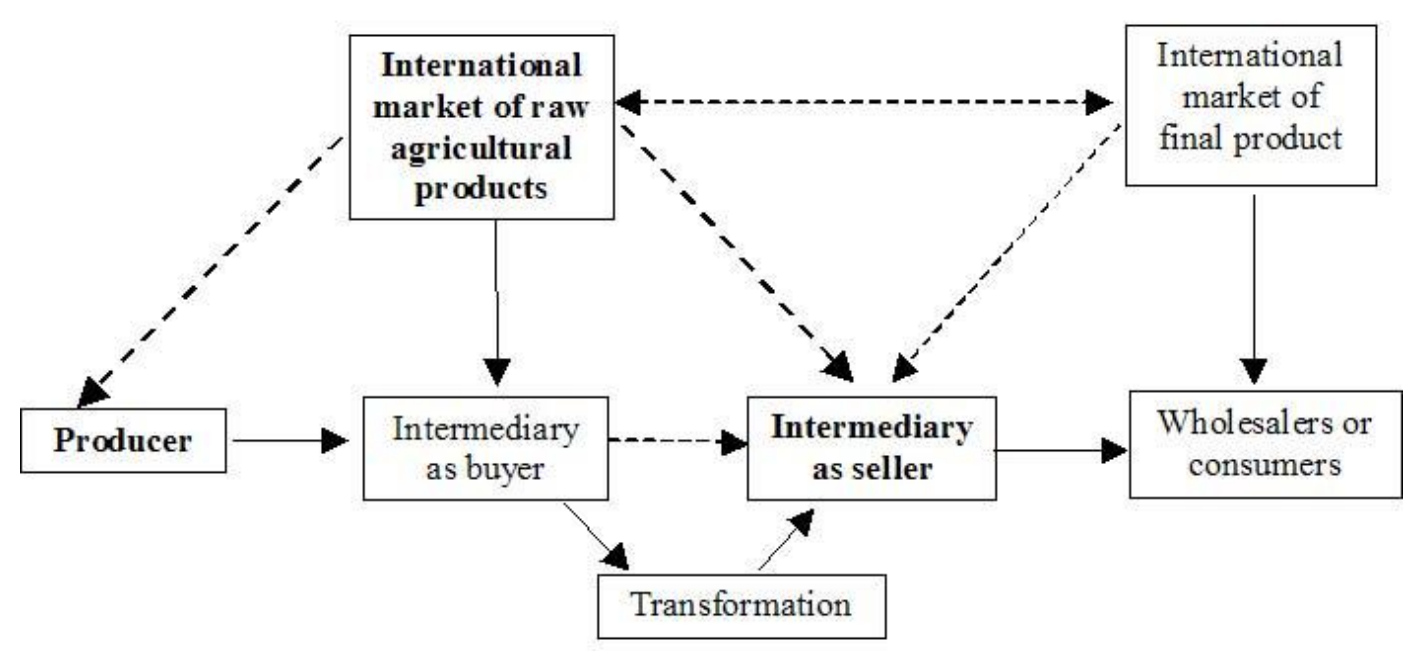


The two boxes on the higher part of Figure 4.3 are the international markets of raw and final products, from which intermediaries or wholesalers can respectively import. The box "Intermediary as buyer" represents the moment where the intermediary buys from farmers or importers. The other box "Intermediary as seller" symbolizes the reselling of the transformed product to wholesalers or consumers. Note as well that all dashed arrows in Figure 4.3 represent price transmission paths and that those that are in bold are the ones that are analyzed in this paper. Finally, the three boxes in bold correspond to the three prices analyzed here.

It is the succession of physical flows explained above that allows price transmission to take place along the marketing chain. Even if there is no physical transactions between the international market of raw agricultural products and the agricultural market where the producer sells his product, price transmission between the two indeed occurs through the intermediary: when the intermediary buys from the producer, he takes into account the import price in the determination of the price paid to the farmer. This price transmission route is depicted in Figure 4.3 by the dashed arrow on the far left.

Similarly, while there is no physical flow between the international market for raw products and the intermediary reselling price, price transmission between these two markets occurs through two routes. First, the intermediary reselling price is influenced by its buying price, which itself depends on the import price (either because the product was imported or because of the first price transmission route we explained before). This is depicted by the dashed arrow between the two intermediary boxes. Second, because the intermediary and the wholesaler will determine their transaction price taking the final product's import price into account (recall that wholesalers can directly import the final product), the reselling price is obviously linked to the final product price on the international market (and hence the dashed arrow between the international market for final products to the intermediary selling box). And since the international raw product price and the international final product price are linked (dashed arrow between the two markets), there is a price transmission route between the international market for raw products to the reselling market (bold dashed arrow between the two).

In conclusion, assuming that markets do not suffer from distortions, such as imports barriers, government control, or market power on the intermediary's side, according to these hypotheses, price transmission should take place between the three markets considered.

\subsection{Research Findings}

Before cointegration tests and error correction models are applied to the international-domestic prices pairs, unit root tests (URT) are run on every price series. These tests were done following the process proposed by Enders (1995), and were applied to different transformations of the series (in log form, with or without deseasonalizing the series) to avoid restricting the URT results by arbitrarily using a sole transformation. Moreover, following Maddala and Kim (2004, Chapters 3 and 4), according to which the usual Augmented Dickey-Fuller tests, Phillip-Perron tests and KPSS tests are not robust, the more powerful and robust Dickey-Fuller GLS test (or "DF-GLS") was applied. Finally, to be able to distinguish between a $\mathrm{I}(1)$ series and a $\mathrm{I}(0)$ series with a structural break, the tests proposed by Perron 
(1989) and Zivot and Andrews (1992), which allow for the inclusion of one or more structural break in the unit root test, were used.

As expected, the conclusions of all these tests do not always converge and there can be more than one possible stationarity level for the same series. In order to not restrict the analysis excessively, a series is eliminated from the analysis only when the unit root tests totally diverge, that is, whenever the tests give three or more stationary levels. The result of the URT is then called "undetermined".

The results of the URT are given in the second column of Table 4.3. Notice that all international prices are concluded to be I(1) (see bottom Table 4.3). The third column defines whether the cointegration analysis is carried on or not for each series. Recall that the analysis is not carried out if the URT is undetermined; this is also the case whenever the series is $\mathrm{I}(0)$, since the series which the domestic prices are to be compared with the international prices are $\mathrm{I}(1)$. We can see that all series in Guatemala were excluded, i.e., that no price transmission analysis will be made for this country.

To evaluate the cointegration relationships, the Johansen trace test and maximum eigenvalue test (Johansen, 1988; see Maddala \& Kim, 2004) were applied. Moreover, the Engle and Granger (Engle \& Granger; 1987; see Ender, 1995) residual-based test was applied to the residuals of equation (3.1) or in the cases with structural break to the residuals of equations (3.2.1), (3.2.2) or (3.2.3). The residualbased test requires that the critical values of the unit root test be modified (see Maddala \& Kim, 2004). Because no modified values for the DF-GLS test were found, we decided to use both the unmodified DF-GLS test and the modified ADF test (which modified values can be found in Phillips \& Ouliaris, 1990), since the former is more robust than the latter, but the latter has modified critical values. Finally, whenever these three tests were in contradiction, the Saikkonen-Lütkepohl (Lütkepohl \& Krätzig, 2006) cointegration test was used to have a final conclusion.

The results of these cointegration tests can be found in columns 5-9 of Table 4.3 and the overall conclusion is given in the last column. We can see that there is strong evidence of cointegration in all pairs of prices analyzed for the maize market. Cointegration also seems quite strong between international prices and producer prices for the rice market. This is however not the case with intermediary rice prices: many of the pairs of prices are not cointegrated and in Central America, most of the cointegrated pairs are between the intermediary rice price and the Thai price, which does not make much sense, since Central America does not import from Thailand (more on that below).

Whenever there is evidence of cointegration, symmetric and asymmetric error correction models (ECM) are estimated. Following the method proposed by Engle and Granger (see Enders, 1995, p. 373), the symmetric ECM is estimated using the residuals of equation (3.1), or of equations or equation (3.2.1), (3.2.2) or (3.2.3) in the case of a structural break, obtained during the cointegration analysis. That is, (3.3.3) and (3.3.3) are regressed in a VAR form, plugging in the past residuals $\mathrm{ECT}_{\mathrm{t}-1}$ of equation (3.1). As for the asymmetric ECM, equations (4.1.1) and (4.1.2) are estimated in a VAR form again. A likelihood ration test, testing if $\alpha^{+}$is significantly different from $\alpha^{-}$(see equations (4.1.1) and (4.1.2)), is finally applied to determine which of the symmetric and asymmetric models is 
more conclusive. The usual procedure for estimating an ECM (determining how many lags to include, whether a trend and/or a constant should be included, including dummies representing isolated events, testing for autocorrelation and normality (skewness) of the residuals) is carried out.

Table 4. 3

Unit Root and Cointegration Tests Results

\begin{tabular}{|c|c|c|c|c|c|c|c|c|c|}
\hline \multirow[t]{2}{*}{ Country } & \multirow{2}{*}{$\begin{array}{l}\text { Unit root tests } \\
\text { conclusion }\end{array}$} & \multirow{2}{*}{$\begin{array}{c}\text { Next } \\
\text { analysis } \\
\text { carried on? }\end{array}$} & \multirow{2}{*}{$\begin{array}{c}\text { International } \\
\text { price compared } \\
\text { with }\end{array}$} & \multirow{2}{*}{$\begin{array}{l}\text { Johansen } \\
\text { trace test }\end{array}$} & \multirow{2}{*}{$\begin{array}{c}\text { Johansen } \\
\text { max.eigen value } \\
\text { test }\end{array}$} & \multicolumn{2}{|c|}{$\begin{array}{l}\text { Cointegration tests Engle- } \\
\text { Granger test }\end{array}$} & \multirow{2}{*}{$\begin{array}{l}\text { Saikkonen- } \\
\text { Lkepohltest }\end{array}$} & \multirow[t]{2}{*}{ Result } \\
\hline & & & & & & Df-GLS & Modifed ADF & & \\
\hline \multicolumn{10}{|c|}{ Intermediary rice price } \\
\hline \multirow{2}{*}{ CostaRica } & \multirow{2}{*}{$\mathrm{I}(0) / \mathrm{I}(1)$} & \multirow{2}{*}{ Yes } & Tailandia & Undetermined & Undetermined & Yes & Yes & Yes & Cointegration \\
\hline & & & USA & Yes & Yes & Yes & No & Yes & Cointegration \\
\hline Guatemala & Undetermined & No & & & & & & & \\
\hline \multirow{2}{*}{ ElSalvador } & \multirow{2}{*}{$\mathrm{I}(1) / \mathrm{I}(2)$} & \multirow{2}{*}{ Yes } & Tailandia & Yes & Yes & Yes & Yes & & Cointegration \\
\hline & & & USA & No & No & Yes & No & No & No cointegration \\
\hline \multirow{2}{*}{ Nicaragua } & \multirow{2}{*}{$\mathrm{I}(1)$} & \multirow{2}{*}{ Yes } & Tailandia & Yes & Yes & Yes & Yes & & Cointegration \\
\hline & & & USA & No & No & No & No & & No cointegration \\
\hline \multirow{2}{*}{ Panama } & \multirow{2}{*}{$\mathrm{I}(0) / \mathrm{I}(1)$} & Yes & Tailandia & Yes & Yes & No & No & No & No Cointegration \\
\hline & & Yes & USA & No & No & No & No & & No cointegration \\
\hline Honduras & J(1) & Yes & Tailandia & Undetermined & Undetermined & Yes & Yes & & Cointegration \\
\hline Honduras & (1) & Yes & USA & No & No & Undetermined & Undetermined & & No cointegration \\
\hline Chile & $\mathrm{I}(0)$ & No & & & & & & & \\
\hline & & & Tailandia & No & No & Yes & Yes & No & No Cointegration \\
\hline Brazil & $\mathrm{I}(1)$ & Yes & Argentina & Yes & Yes & Yes & Yes & & Cointegration \\
\hline & & & Uruguay & Yes & Yes & Yes & No & & Cointegration \\
\hline Producer & e price & & & & & & & & \\
\hline CostaRica & Undetermined & No & & & & & & & \\
\hline Nicaraqua & $\mathrm{I}(0) / \mathrm{I}(1)$ & Yes & Tailandia & Yes & Yes & Yes & Yes & & Cointegration \\
\hline Nicaragua & $1(0) / 1(1)$ & Yes & USA & Yes & Yes & Yes & Yes & & Cointegration \\
\hline Panama & $\mathrm{I}(0)$ & No & & & & & & & \\
\hline Honduras & I(1) & Yes & Tailandia & Yes & No & Yes & Yes & & Cointegration \\
\hline Honduras & (1) & res & USA & Yes & Yes & No & Yes & Yes & Cointegration \\
\hline & & & Tailandia & No & Undetermined & Yes & No & No & No Cointegration \\
\hline Brazil & $\mathrm{I}(1)$ & Yes & Argentina & Yes & No & Yes & Yes & Yes & Cointegration \\
\hline & & & Uruguay & No & No & Yes & No & Yes & Cointegration \\
\hline Intermedic & y maize price & & & & & & & & \\
\hline CostaRica & $\mathrm{I}(1)$ & Yes & USA & Yes & Yes & Yes & Yes & & Cointegration \\
\hline Guatemala & Undetermined & No & & & & & & & \\
\hline Panama & Undetermined & No & & & & & & & \\
\hline Chile & $\mathrm{I}(1) / \mathrm{I}(2)$ & Yes & USA & Yes & Yes & Yes & Yes & & Cointegration \\
\hline Cnile & $\Pi(1) / 1(2)$ & res & Argentina & Yes & Yes & Yes & Yes & & Cointegration \\
\hline Brazil & $\mathrm{I}(0) / \mathrm{I}(1)$ & Yes & USA & Yes & Yes & Yes & Yes & & Cointegration \\
\hline DrazII & $1(0) / 1(1)$ & & Argentina & Yes & Yes & Yes & Yes & & Cointegration \\
\hline Producer & aize price & & & & & & & & \\
\hline Panama & $\mathrm{I}(0) / \mathrm{I}(1)$ & Yes & USA & Yes & Yes & Yes & Yes & & Cointegration \\
\hline Brazil & $\mathrm{I}(0)$ & No & & & & & & & \\
\hline Internation & Prices & & Unit $\mathrm{R}$ & Root Test Conclu & lusions & & & & \\
\hline & Thaila & and & & $\mathrm{I}(1)$ & & & & & \\
\hline Rice & US & & & $\mathrm{I}(1)$ & & & & & \\
\hline Rice & Argent & tina & & $\mathrm{I}(1)$ & & & & & \\
\hline & Urugu & & & $\mathrm{I}(1)$ & & & & & \\
\hline Maize & US $A$ & & & $\mathrm{I}(1)$ & & & & & \\
\hline Mazze & Argent & tina & & $\mathrm{I}(1)$ & & & & & \\
\hline
\end{tabular}

All tests are significant at the 5\% level

Source: Author's Elaboration.

Results of the strength of the cointegration relationship and of the ECMs are given in Table 4.4. The first two columns show the pair of prices analyzed. If the cointegration equation does not contain a structural break or if the break is only in the constant, the unique $\beta_{1}^{1}$ is given in column 3 . If there is a structural break in the slope (see Section 3.3) the cointegration coefficients $\beta_{1}^{1}$ and $\beta_{1}^{1}+\beta_{1}^{2}$ (since $\beta_{1}^{2}$ is an interaction term, the cointegration coefficient after the break is the sum of the two $\beta_{1}$ ) are given in columns 3 and 4 and the average of the two are given in column 5. Finally, the date of the break is 
indicated in the sixth column. The symmetric and asymmetric ECMs are shown in the rest of Table 4.4. Since the ECM is estimated in a VAR form, this allows us to probe the direction of the price transmission (i.e that price transmission goes from the international price to the domestic one and not the other way round).

Table 4. 4

ECM Results

\begin{tabular}{|c|c|c|c|c|c|c|c|c|c|c|c|c|c|c|}
\hline \multirow[b]{2}{*}{$P^{y}{ }_{t}$} & \multirow[b]{2}{*}{$\mathrm{P}^{\mathrm{x}}{ }_{\mathrm{t}}$} & \multirow[b]{2}{*}{$\beta_{1}^{1}+$} & \multirow[b]{2}{*}{$\left(\beta^{1}{ }_{1}+\beta^{2}{ }_{1}\right) \dagger$} & \multirow[b]{2}{*}{$\begin{array}{c}\text { Averague } \\
\beta_{1}+++\end{array}$} & \multirow[b]{2}{*}{$\begin{array}{l}\text { Break } \\
\text { point }\end{array}$} & \multicolumn{4}{|c|}{ Symmetric ECM $\ddagger$} & \multirow[b]{2}{*}{$\alpha^{+} \dagger$} & \multicolumn{3}{|c|}{ Asymmetric ECM $\ddagger$} & \multirow[b]{2}{*}{$\begin{array}{c}\text { Test } \alpha^{+}=\alpha, \\
x^{2} \Uparrow\end{array}$} \\
\hline & & & & & & & $\alpha_{\mathrm{i}} \dagger$ & $\begin{array}{c}\text { Autocorrelation } \\
\qquad x^{2} \uparrow\end{array}$ & $\begin{array}{c}\text { Normality } \\
\text { (skewness) } \\
\chi^{2}+\dagger \\
\end{array}$ & & $\alpha \dagger$ & $\begin{array}{l}\text { Autocorrelation } \\
\qquad x^{2} \dagger \dagger\end{array}$ & $\begin{array}{c}\text { Normality } \\
\text { (skewness) } \\
\chi 2 \dagger \dagger \\
\end{array}$ & \\
\hline \multicolumn{15}{|c|}{ RICE: Intermediary Price } \\
\hline \multirow{2}{*}{ Costa Rica } & \multirow{2}{*}{ Thailand } & $0.47^{* * *}$ & $0.15 * * *$ & \multirow{2}{*}{0.23} & \multirow{2}{*}{$\begin{array}{l}\mathrm{Feb} \\
2002\end{array}$} & $\alpha_{\mathrm{y}}$ & $\begin{array}{c}-0.31 \text { **** } \\
(-4.22) \\
\end{array}$ & $\begin{array}{c}1.47 \\
(0.23) \\
\end{array}$ & $\begin{array}{c}2.3 \\
(0.009) \\
\end{array}$ & $\begin{array}{l}-0.27 * * \\
(-2.41) \\
\end{array}$ & $\begin{array}{l}-0.33^{* * * *} \\
(-3.58) \\
\end{array}$ & $\begin{array}{c}1.43 \\
(0.23) \\
\end{array}$ & $\begin{array}{c}2.06 \\
(0.00) \\
\end{array}$ & 0.79 \\
\hline & & $(4.69)$ & $(2.76)$ & & & $\alpha_{\mathrm{x}}$ & $\begin{array}{l}0.14 \\
(1.25 \\
\end{array}$ & $\begin{array}{c}0.76 \\
(0.38) \\
\end{array}$ & $\begin{array}{c}0.97 \\
(0.00)\end{array}$ & $\begin{array}{c}0.12 \\
((0.84) \\
\end{array}$ & $\begin{array}{c}0.18 \\
(1.38) \\
\end{array}$ & $\begin{array}{c}0.04 \\
(0.84) \\
\end{array}$ & $\begin{array}{c}0.92 \\
(0.00)\end{array}$ & $(0.67)$ \\
\hline \multirow{2}{*}{ Costa Rica } & \multirow{2}{*}{ USA } & $0.84 * * *$ & $0.26 * * *$ & \multirow{2}{*}{0.47} & \multirow{2}{*}{$\begin{array}{c}\text { Jan } \\
2003\end{array}$} & $\alpha_{\mathrm{y}}$ & $\begin{array}{c}-0.27 * * * \\
(-4.65) \\
\end{array}$ & $\begin{array}{c}0.51 \\
(0.48) \\
\end{array}$ & $\begin{array}{c}1.93 \\
(0.00) \\
\end{array}$ & $\begin{array}{l}-0.24 * * \\
(-2.50) \\
\end{array}$ & $\begin{array}{l}-0.30^{\text {**** }} \\
(-3.46)\end{array}$ & $\begin{array}{c}0.73 \\
(0.39) \\
\end{array}$ & $\begin{array}{c}1.85 \\
(0.00) \\
\end{array}$ & 0.18 \\
\hline & & $(9.37)$ & (5.08) & & & $\alpha_{\mathrm{x}}$ & $\begin{array}{c}0.10 \\
(1.61)\end{array}$ & $\begin{array}{c}0.17 \\
(0.68)\end{array}$ & $\begin{array}{l}-0.26 \\
(0.24)\end{array}$ & $\begin{array}{c}-0.12 \\
(-1.31)\end{array}$ & $\begin{array}{c}0.28 * * * \\
(3.29)\end{array}$ & $\begin{array}{c}0.00 \\
(0.99)\end{array}$ & $\begin{array}{l}-0.11 \\
(0.65)\end{array}$ & $(0.67)$ \\
\hline \multirow{2}{*}{ El Salvador } & \multirow{2}{*}{ Thailand } & $0.85^{* * *}$ & $0.40 * *$ & \multirow{2}{*}{0.78} & \multirow{2}{*}{$\begin{array}{l}\text { Aug } \\
2007\end{array}$} & $\alpha_{\mathrm{y}}$ & $\begin{array}{c}-0.56^{* * * *} \\
(-4,61) \\
\end{array}$ & $\begin{array}{c}0.43 \\
(0.51) \\
\end{array}$ & $\begin{array}{c}0.41 \\
(0.11) \\
\end{array}$ & $\begin{array}{r}-0.07 \\
(-0.36) \\
\end{array}$ & $\begin{array}{c}-1.07^{\text {**** }} \\
(-5,51) \\
\end{array}$ & $\begin{array}{c}0.30 \\
(0.58) \\
\end{array}$ & $\begin{array}{c}0.04 \\
(0.88)\end{array}$ & $10.53 * * *$ \\
\hline & & $(6.25)$ & (2.07) & & & $\alpha_{\mathrm{x}}$ & $\begin{array}{l}0.04 \\
(1.30 \\
\end{array}$ & $\begin{array}{r}7.67 \\
(0.01) \\
\end{array}$ & $\begin{array}{r}0.49 \\
(0.06) \\
\end{array}$ & $\begin{array}{c}0.03 \\
(0.55) \\
\end{array}$ & $\begin{array}{c}0.05 \\
(1.01) \\
\end{array}$ & $\begin{array}{r}7.41 \\
(0.01) \\
\end{array}$ & $\begin{array}{r}0.49 \\
(0.06) \\
\end{array}$ & $(0.00)$ \\
\hline \multirow{2}{*}{ Nicaragua } & \multirow{2}{*}{ Thailand } & $0.74 * * *$ & & \multirow{2}{*}{0.66} & \multirow{2}{*}{$\begin{array}{l}\text { Sep } \\
2007\end{array}$} & $\alpha_{\mathrm{y}}$ & $\begin{array}{l}-0,97 \text { **** } \\
(-8,39)\end{array}$ & $\begin{array}{c}0.34 \\
(0.56)\end{array}$ & $\begin{array}{c}0.83 \\
(0.00)\end{array}$ & $\begin{array}{l}-0.64 * * * \\
(-3.99)\end{array}$ & $\begin{array}{l}-1.26^{* * * *} \\
(-8.40)\end{array}$ & $\begin{array}{c}0.23 \\
(0.63)\end{array}$ & $\begin{array}{c}0.32 \\
(0.22)\end{array}$ & $23.36 * * *$ \\
\hline & & $(6.44)$ & $(2.80)$ & & & $\alpha_{\mathrm{x}}$ & $\begin{array}{c}0.01 \\
(0.07) \\
\end{array}$ & $\begin{array}{c}6.36 \\
(0.01) \\
\end{array}$ & $\begin{array}{c}0.24 \\
(0.35) \\
\end{array}$ & $\begin{array}{l}-0.10^{* * *} \\
(-2.15) \\
\end{array}$ & $\begin{array}{l}0.09 * * \\
(2.11) \\
\end{array}$ & $\begin{array}{c}3.95 \\
(0.05) \\
\end{array}$ & $\begin{array}{c}0.89 \\
(0.00) \\
\end{array}$ & $(0.00)$ \\
\hline Honduras & Thailand & $0.59^{* * *}$ & & & & $\alpha_{\mathrm{y}}$ & $\begin{array}{l}-0.29 * * * \\
(-2.77) \\
\end{array}$ & $\begin{array}{c}0.04 \\
(0.85) \\
\end{array}$ & $\begin{array}{c}0.39 \\
(0.53) \\
\end{array}$ & $\begin{array}{c}-0.16 \\
(-1.08) \\
\end{array}$ & $\begin{array}{l}-0.39^{\text {***** }} \\
(-2.86) \\
\end{array}$ & $\begin{array}{c}0.18 \\
(0.67) \\
\end{array}$ & $\begin{array}{c}0.02 \\
(0.89) \\
\end{array}$ & 1.77 \\
\hline Honduras & Inauland & (17.12) & & & & $\alpha_{\mathrm{x}}$ & $\begin{array}{c}0.08 \\
(1.35) \\
\end{array}$ & $\begin{array}{c}0.49 \\
(0.48) \\
\end{array}$ & $\begin{array}{c}4.71 \\
(0.03) \\
\end{array}$ & $\begin{array}{c}0.45 \\
(0.52) \\
\end{array}$ & $\begin{array}{c}0.11 \\
(1.39) \\
\end{array}$ & $\begin{array}{c}0.29 \\
(0.59) \\
\end{array}$ & $\begin{array}{c}6.48 \\
(0.01) \\
\end{array}$ & $(0.41)$ \\
\hline Brazil & Argentina & $1.02^{* * * *}$ & & 0.99 & Oct & $\alpha_{\mathrm{y}}$ & $\begin{array}{l}-0.48 * * \\
(-4.60) \\
\end{array}$ & $\begin{array}{c}1.75 \\
(0.19) \\
\end{array}$ & $\begin{array}{c}0.02 \\
(0.95) \\
\end{array}$ & $\begin{array}{l}-0.30^{* *} \\
(-2.16) \\
\end{array}$ & $\begin{array}{l}-0.65^{\text {**** }} \\
(-4,90)\end{array}$ & $\begin{array}{c}2.71 \\
(0.10)\end{array}$ & $\begin{array}{l}-0.37 \\
(0.12)\end{array}$ & $4.54 *$ \\
\hline Brazil & Argentina & (12.82) & $(-1.79)$ & 0.99 & 2007 & $\alpha_{\mathrm{x}}$ & $\begin{array}{l}0.15^{* * *} \\
(2.19) \\
\end{array}$ & $\begin{array}{c}0.14 \\
(0.70)\end{array}$ & $\begin{array}{c}2.08 \\
(0.00)\end{array}$ & $\begin{array}{l}0.25^{* * * *} \\
(2.79)\end{array}$ & $\begin{array}{c}0.06 \\
(0.69) \\
\end{array}$ & $\begin{array}{c}0.20 \\
(0.65) \\
\end{array}$ & $\begin{array}{c}2.01 \\
(0.00)\end{array}$ & $(0.10)$ \\
\hline Brazil & Uruguay & $1.01 * * *$ & & & & $\alpha_{\mathrm{y}}$ & $\begin{array}{l}-0.28 * * \\
(-2.00) \\
\end{array}$ & $\begin{array}{c}0.01 \\
(0.92)\end{array}$ & $\begin{array}{c}0.08 \\
(0.73) \\
\end{array}$ & $\begin{array}{r}-0.17 \\
(-1.21) \\
\end{array}$ & $\begin{array}{l}-0.34^{* *} \\
(-2.61) \\
\end{array}$ & $\begin{array}{c}0.69 \\
(0.41) \\
\end{array}$ & $\begin{array}{c}3.66 \\
(0.06) \\
\end{array}$ & 3.07 \\
\hline Brazil & Uruguay & $(33.92)$ & & & & $\alpha_{\mathrm{x}}$ & $\begin{array}{c}0.14 \\
(1.63) \\
\end{array}$ & $\begin{array}{c}3.73 \\
(0.05) \\
\end{array}$ & $\begin{array}{c}1.01 \\
0.00) \\
\end{array}$ & $\begin{array}{l}0.19^{*} \\
(1.73) \\
\end{array}$ & $\begin{array}{c}0.09 \\
(0.86)\end{array}$ & $\begin{array}{c}3.60 \\
(0.06) \\
\end{array}$ & $\begin{array}{c}1.04 \\
(0.00)\end{array}$ & $(0.22)$ \\
\hline RICE: $\mathrm{Pl}$ & roducer $P$ & Price & & & & & & & & & & & & \\
\hline Nicaragua & Thailand & $0.18^{* * *}$ & & & Jul 199 & $\alpha_{y}$ & $\begin{array}{l}-0.26^{* * * *} \\
(-5.42) \\
\end{array}$ & $\begin{array}{c}0.41 \\
(0.52)\end{array}$ & $\begin{array}{l}-0.35 \\
(0.04) \\
\end{array}$ & $\begin{array}{l}-0.20^{* * * *} \\
(-2.66)\end{array}$ & $\begin{array}{l}-0.31 \text { **** } \\
(-5.01)\end{array}$ & $\begin{array}{c}0.12 \\
(0.73)\end{array}$ & $\begin{array}{l}-0.53 \\
(0.00)\end{array}$ & 1.84 \\
\hline Nid al agua & TIandanu & (3.44) & & & & $\alpha_{\mathrm{x}}$ & $\begin{array}{c}-0.01 \\
(-0.14) \\
\end{array}$ & $\begin{array}{r}4.49 \\
(0.03) \\
\end{array}$ & $\begin{array}{r}-0.02 \\
(0.89) \\
\end{array}$ & $\begin{array}{c}0.02 \\
(0.35) \\
\end{array}$ & $\begin{array}{c}-0.02 \\
(0.35) \\
\end{array}$ & $\begin{array}{c}4.43 \\
(0.04) \\
\end{array}$ & $\begin{array}{l}-0.14 \\
(0.42) \\
\end{array}$ & $(0.40)$ \\
\hline Nicaragu & USA & $0.09 * * *$ & & & Aug & $\alpha_{\mathrm{y}}$ & $\begin{array}{l}-0.29 * * * \\
(-5.78) \\
\end{array}$ & $\begin{array}{c}0.93 \\
(0.33) \\
\end{array}$ & $\begin{array}{l}-0.20 \\
(0.24) \\
\end{array}$ & $\begin{array}{l}-0.19 * * * \\
(-2.67) \\
\end{array}$ & $\begin{array}{l}-0.19 * * * \\
(-2.67) \\
\end{array}$ & $\begin{array}{c}0.43 \\
(0.51)\end{array}$ & $\begin{array}{l}-0.45 \\
(0.01)\end{array}$ & 4.46 \\
\hline Nicaragua & USA & (1.77) & & & 1998 & $\alpha_{\mathrm{x}}$ & $\begin{array}{c}0.01 \\
(0.45) \\
\end{array}$ & $\begin{array}{c}5.19 \\
(0.02) \\
\end{array}$ & $\begin{array}{c}1.21 \\
(0.00) \\
\end{array}$ & $\begin{array}{c}0.01 \\
(0.17) \\
\end{array}$ & $\begin{array}{c}0.01 \\
(0.17) \\
\end{array}$ & $\begin{array}{c}5.16 \\
(0.029 \\
\end{array}$ & $\begin{array}{c}1.23 \\
(0.00) \\
\end{array}$ & $(0.11)$ \\
\hline Honduras & Thailand & $0.17 * *$ & & & Mar & $\alpha_{\mathrm{y}}$ & $\begin{array}{c}-0.43^{* * * *} \\
(-5.26) \\
\end{array}$ & $\begin{array}{c}3.33 \\
(0.07) \\
\end{array}$ & $\begin{array}{l}-0.38 \\
(0.07) \\
\end{array}$ & $\begin{array}{l}-0.44 * * * \\
(-4.77) \\
\end{array}$ & $\begin{array}{l}-0.44 * * * \\
(-4.77) \\
\end{array}$ & $\begin{array}{c}3.13 \\
(0.08) \\
\end{array}$ & $\begin{array}{r}-0.33 \\
(0.12) \\
\end{array}$ & 0.09 \\
\hline Honduras & Inailana & $(2.20)$ & & & 1990 & $\alpha_{x}$ & $\begin{array}{c}-0.07 \\
(-1.44) \\
\end{array}$ & $\begin{array}{c}1.10 \\
(0.29) \\
\end{array}$ & $\begin{array}{c}0.22 \\
(0.30) \\
\end{array}$ & $\begin{array}{r}-0.06 \\
(-1.18) \\
\end{array}$ & $\begin{array}{c}-0.06 \\
(-1.18) \\
\end{array}$ & $\begin{array}{c}1.25 \\
(0.26) \\
\end{array}$ & $\begin{array}{c}0.18 \\
(0.40) \\
\end{array}$ & $(0.96)$ \\
\hline Honduras & USA & $0.27^{*}$ & & & & $\alpha_{\mathrm{y}}$ & $\begin{array}{l}-0.32 * * * \\
(-4.06) \\
\end{array}$ & $\begin{array}{c}0.00 \\
(0.95) \\
\end{array}$ & $\begin{array}{c}-0.14 \\
(0.60)\end{array}$ & $\begin{array}{l}-0.41^{\text {**** }} \\
(-4.00) \\
\end{array}$ & $\begin{array}{c}-0.21 * \\
(-1.87) \\
\end{array}$ & $\begin{array}{c}0.85 \\
(0.36)\end{array}$ & $\begin{array}{c}0.22 \\
(0.43)\end{array}$ & 1.93 \\
\hline Honduras & USA & $(1.82)$ & & & & $\alpha_{x}$ & $\begin{array}{c}0.23 \\
(0.63) \\
\end{array}$ & $\begin{array}{c}2.04 \\
(0.15) \\
\end{array}$ & $\begin{array}{c}1.39 \\
(0.00) \\
\end{array}$ & $\begin{array}{c}0.12 \\
(0.25) \\
\end{array}$ & $\begin{array}{c}0.36 \\
(0.70) \\
\end{array}$ & $\begin{array}{c}2.00 \\
(0.16) \\
\end{array}$ & $\begin{array}{c}1.46 \\
(0.00) \\
\end{array}$ & $(0.38)$ \\
\hline & & $0.70^{* * * *}$ & & & Jul 200 & $\alpha_{\mathrm{y}}$ & $\begin{array}{c}-0.17^{* * * *} \\
(-2.90)\end{array}$ & $\begin{array}{c}0.00 \\
(0.96) \\
\end{array}$ & $\begin{array}{c}0.37 \\
(0.11) \\
\end{array}$ & $\begin{array}{r}-0.14 \\
(-1.59) \\
\end{array}$ & $\begin{array}{l}-0.20^{* * *} \\
(-2.38) \\
\end{array}$ & $\begin{array}{c}0.01 \\
(0.93)\end{array}$ & $\begin{array}{c}0.29 \\
(0.22)\end{array}$ & 0.69 \\
\hline Brazil & Argentina & $(21.27)$ & & & Jul 200 & $\alpha_{\mathrm{x}}$ & $\begin{array}{c}0.12 \\
(1.87)\end{array}$ & $\begin{array}{c}0.24 \\
(0.63)\end{array}$ & $\begin{array}{c}2.13 \\
(0.00)\end{array}$ & $\begin{array}{l}0.18^{*} \\
(1.87)\end{array}$ & $\begin{array}{c}0.07 \\
(0.72)\end{array}$ & $\begin{array}{c}0.47 \\
(0.49)\end{array}$ & $\begin{array}{c}2.04 \\
(0.00)\end{array}$ & $(0.71)$ \\
\hline & & $1.00^{* * *}$ & $0.59^{* *}$ & & Dic & $\alpha_{y}$ & $\begin{array}{l}-0.19 \text { **** } \\
(-2.73) \\
\end{array}$ & $\begin{array}{c}0.51 \\
(0.48) \\
\end{array}$ & $\begin{array}{c}0.28 \\
(0.23) \\
\end{array}$ & $\begin{array}{c}-0.15 \\
(-1.40) \\
\end{array}$ & $\begin{array}{l}-0.21^{* *} \\
(-2.36) \\
\end{array}$ & $\begin{array}{c}0.61 \\
(0.44)\end{array}$ & $\begin{array}{c}0.22 \\
(0.35)\end{array}$ & 0.52 \\
\hline Brazil & Uruguay & (14.24) & $(6.00)$ & 0.86 & 2005 & $\alpha_{\mathrm{x}}$ & $\begin{array}{c}0.10 \\
(1.32) \\
\end{array}$ & $\begin{array}{c}0.11 \\
(0.74) \\
\end{array}$ & $\begin{array}{c}1.44 \\
(0.00) \\
\end{array}$ & $\begin{array}{c}0.07 \\
(0.62) \\
\end{array}$ & $\begin{array}{c}0.12 \\
(1.19) \\
\end{array}$ & $\begin{array}{c}0.10 \\
(0.75) \\
\end{array}$ & $\begin{array}{c}1.46 \\
(0.00) \\
\end{array}$ & $(0.78)$ \\
\hline
\end{tabular}

\section{Continue}




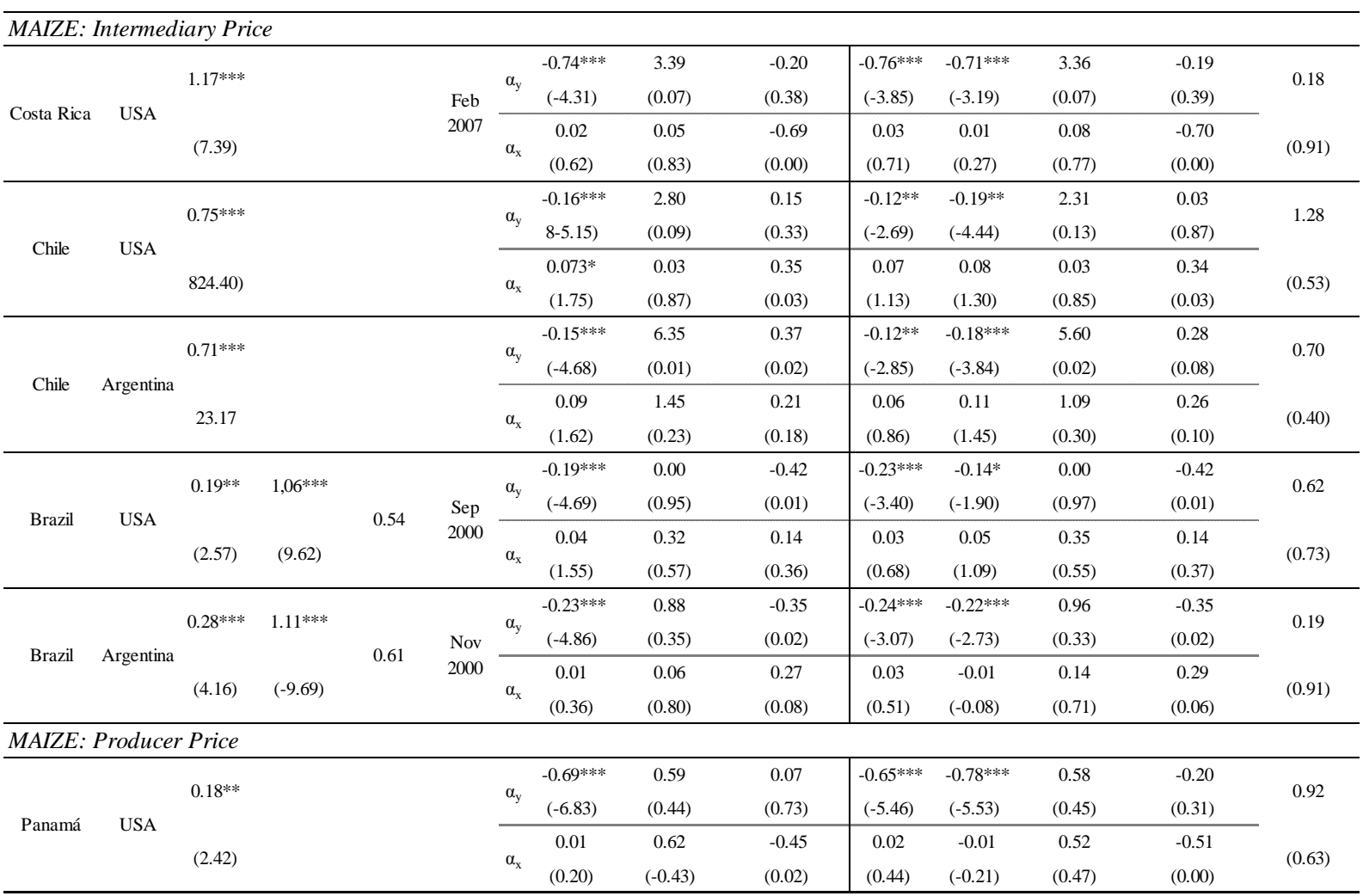

$\dagger \mathrm{t}$-value in brackets.

$\dagger \dagger$ p-value in brackets.

$+\dagger \dagger$ This average is weighted by the number of months before and after the break.

\$ The results of normality and autocorrelation correspond to the errors of ECMs.

*** means significance difference $P<0.01, * * 0.05$, * 0.10

Source: Author's Elaboration.

We can see that all cointegration coefficients $\beta_{1}^{1}$ are significant and positive. Hence, as the international price increases, the domestic prices do too. Moreover, since all series are in log form, $\beta_{1}^{1}$ can be interpreted as the elasticity of adjustment in the long run. Note also that in most of the cases, the cointegration coefficient after the structural break is lower than before (see for example the pair Costa Rica -Thailand for the intermediary rice price, where the cointegration coefficient goes from 0.47 to 0.15 ). Considering that the time period after the structural break covers the period of the dramatic increase in prices, this reduction in the strength of price transmission may be a consequence of it. It is indeed possible that the pace at which the international prices increased was too fast for domestic prices to adjust as quickly as before. It could also be that the measures taken by governments with the purpose of lessening problems of food security in the country during the boom in prices could have affected price transmission. For instance, measures like fixing a maximum consumer price or reducing import tariffs, measures that moderate the impact on domestic markets of the increase in international prices, restrained the strength of price transmission to domestic prices.

The short run coefficients $\alpha_{\mathrm{y}}$ and $\alpha_{\mathrm{x}}$ are indicated in column 7 of Table 4.4. All $\alpha_{\mathrm{y}}$ are significant and are comprised between -0.15 and -0.97 , which shows a great difference in the speed of price transmission among the pairs of prices analyzed. For the pairs Brazil-Argentina (intermediary rice prices) and Chile -USA (intermediary maize prices) $\alpha_{\mathrm{x}}$ is also significant. In the first case, this link can 
be explained by the fact Brazil is an important economic partner for Argentina. This however cannot be advanced for the second case.

The last part of Table 4.4 gives the results of the asymmetric error correction models. For asymmetry to be conclusive, (i) the Likelihood Ratio test must be rejected (hence the two as are indeed different from one another) and (ii) both $\alpha$ s must be significantly different from zero. As we can see in Table 4.4, the two conditions are only satisfied for the pairs of Nicaragua-Thailand and Brazil-Argentina, in the case of the intermediary rice prices. In addition, for both of these pairs, $\alpha^{+}$is smaller (in absolute values) than $\alpha^{-}$, which means that the adjustment in respond to deviations from the equilibrium is faster when the deviation is negative (i.e., when the international price is lower than the national price) than when it is positive. Considering that a positive deviation means that the international price is higher than the domestic price, this means that domestic prices adjust less rapidly when the international price is relatively higher than when it is relatively lower. Finally, the rejection of the second condition given above is a sign of the non-robustness of the equation, i.e., of little evidence of price transmission. As von Cramon-Taubadel (1998) explains, for example, $\alpha^{+}$is not significant which means that positive deviations from the equilibrium are not corrected for, which eventually leads to an explosive situation.

To give a more intuitive interpretation of these results, impulse response functions were computed (Annex 4.3). They show the monthly adjustment of the domestic price following an initial shock on the international price. This shock is equal to 2 standard deviations from the international price during the time period before the boom in prices. On the one hand, this allows us to compare the adjustment of the different domestic prices and on the other hand, to illustrate what happened during the boom (or how domestic prices would move if such a boom was to happen again), since during that period the international prices increased of 2.3 standard deviations (before-the-boom) on average. The impulse response functions are computed from the estimated equations. In this regard, the average $\beta_{1}$ is used because in many equations with structural break in the slope, the period after the break represents an important part of the whole period. Hence, considering the average $\beta_{1}$ seemed more representative of the whole sample than using the $\beta_{1}^{1}$ before or the $\left(\beta_{1}^{1}+\beta_{1}^{2}\right)$ after the break.

In the next paragraphs, results are commented on country by country ${ }^{1}$.

As can be seen in Table 4.3, in Costa Rica, the intermediary prices for both maize and rice markets are found to be integrated with the international prices. However, that the cointegration tests cannot be made with the producer price, since the unit root test result is undetermined. Moreover, in both equations estimated for the rice market (Table 4.4), the coefficients of cointegration $\beta_{1}$ and the coefficients of short term adjustment, $\alpha_{y}$ and $\alpha_{x}$, are rather low. Hence, for the rice intermediary

\footnotetext{
${ }^{1}$ The interpretation of the results leans strongly to the description of the markets studied that are resumed in Section 4.3. A more detailed description can be found in the Spanish version of this paper, available from the Authors.
} 
market, price transmission is rather weak. This can be explained by the government's price policies: on the one hand, the government sets a minimum price for producers and on the other hand, a maximum wholesale price, which obviously impedes price transmission. This also explains why the normality tests are rejected in both equations (see the behavior of the series in Annex 4.2, Figure 4.9). Nevertheless, because the government refers to the international price to determine these minimum and maximum prices, price transmission should still be existent, although weakly. As for the maize market, price transmission seems quite strong between international prices and the intermediary prices, with a $\beta_{1}$ of more than 1 and $\alpha_{\mathrm{y}}$ of -0.74 . This can reflect the fact that maize production and consumption in Costa Rica have decreased over the years, while imports were increasing, which means a higher dependency of intermediaries on the international market in a shrinking domestic one.

As can be seen in Table 4.5 of Annex 4.1, in El Salvador, data were found only for the intermediary rice price. In this market, evidence of price transmission was found with the international Thai market but not with the USA market. This is rather counter-intuitive, since El Salvador imports mainly from the USA but nothing from Thailand. Price transmission between the Salvadorian and the Thai markets could be explained by the fact that there is a commercial link between the Thai and the USA markets and again between the USA and El Salvador. This, however, could be an explanation if there were price transmission between the USA and the Salvadorian markets. The absence of transmission with the USA market could be explained by the unequal forces among agents of the marketing chain: the Salvadorian rice market is dominated by millers, which producers and consumers have no power against, especially since the government does not sustain any protection measures to the latter whatsoever. Hence, intermediaries are free to determine the producer and consumer prices, which obviously impedes price transmission.

Similarly to El Salvador, the Nicaraguan intermediary rice market shows evidence of price transmission with the Thai market, but not with the USA market. The price transmission with the Thai market is quite strong: $\alpha_{\mathrm{y}}$ is almost -1 , i.e., the adjustment to deviations from equilibrium is almost immediate, and the $\beta_{1}^{1}$ is also quite high. On the other hand, the producer prices do cointegrate with both the Thai and USA markets, even though the price transmission is weak: in both equations, the $\beta_{1}^{1}$ is below 0.20 and the $\alpha_{y}$ does not reach -0.30 . This is reflected in Figure 4.14 (Annex 4.3), which compares the impulse response function of the intermediary and producer prices. Clearly, after a shock in the international price, the intermediary price reaches a new equilibrium much higher than the producer price. Nevertheless, the fact that this equation relates intermediary price of Nicaragua with the Thai price leaves us quite skeptical. The low level of price transmission with the producer price can be explained by the high level of rice import tariffs. Moreover, the determination of the producer price within the PAPA (Programa de Apoyo a los Productores de Arroz) program probably lessens price transmission. The rice prices are determined within the framework of this program. Moreover, under this program the managements of imports and shortages quotas are also established. Also, 
producers not belonging to PAPA are left without any protection at the hands of the industrial firm AGRICORP, which has strong market power.

In the case of Panama, the cointegration tests could not be done for the producer rice price and the intermediary maize price, since the unit root tests were undetermined (Table 4.3). As for the remaining prices, the cointegration results (Table 4.3) show that there is no evidence of price transmission for the intermediary rice price. It is important to note that the intermediaries rice price series covers the period of 1994-2005, period of high tariff equivalent (168\% until 1999 and $40 \%$ afterwards), which obviously impedes price transmission. As for the producer maize price, the elasticity of price transmission is not very high ( $\beta_{1}^{1}$ of 0.18 ), but the adjustment to deviations from the equilibrium is rather fast ( $\alpha_{\mathrm{y}}$ of -0.69$)$. This market, unlike the rice market, was opened much faster and the tariff equivalent was only of $3 \%$ in 1998.

Honduras follows Nicaragua's scheme, where the intermediary rice price shows evidence of price transmission only with the Thai market. The producer price, however, is integrated with both the USA and the Thai market. In this case however, the price band policy implemented from 1993 onwards with the aim of protecting the producer from large variations in prices, and the rice agreement (Convenio del Arroz), created in 1999, through which all rice production is bought by the industry at a fixed price, are two systems that allow the domestic price to be directly related with the Thai price assuming that it is this international reference price which is used to determine the two policies. Whether this hypothesis is true or not, these protective measures for the producer explain the occurrence of the weak price transmission encountered in the Hondurans markets once more.

As can be seen in Table 4.3, the Chilean rice market could not be analyzed. Considering the level of concentration of the industry in this market, weak price transmission can be expected in this market. As for the maize market, integration with the USA and the Argentinean markets are found. The two price transmissions are quite similar; with a high $\beta_{1}^{1}$ and a rather low $\alpha_{\mathrm{y}}$ (Table 4.4). Figure 4.15 (Annex 4.3) show the impulse response functions for this market in Chile. In both cases, the intermediary maize price reaches rapidly a new equilibrium after a shock in the international price. Nevertheless, price transmission seems to be stronger with the USA market since the new equilibrium reached is higher than with the Argentinean market.

Finally, Brazil shows a good level of price transmission in general, since all the domestic markets are integrated with the international ones, except in the case of the producer maize price. Moreover, in line with common sense, the rice market is linked with the Argentinean and Uruguayan markets and not with the Thai market. In addition, for that in that market price transmission is rather strong, since all $\beta_{1}^{1} \mathrm{~s}$ are close to 1 . As for the maize market, evidence of price transmission is also clear, even if the elasticities of price transmission are a bit weaker. This good result goes along with a seemingly rather competitive marketing chain: no evidence of concentration from the part of some actors of the marketing chain could be found, neither a protective measure for the producer. Hence, as theory 
predicts, competitive markets lead to stronger price transmission. It is however necessary to underline the fact that the markets compared in this case, Brazil, Argentina and Uruguay, are much closer than the countries included in the other cases (Central America, USA and Thailand) which could also explain a stronger price transmission. This is somehow reflected in Figure 4.16 (Annex 4.3) which shows the impulse response function for the rice and maize markets in Brazil. The weakest response is for the pair of Brazil-USA maize prices and the strongest for the Brazil-Argentina intermediary rice prices. This figure also shows that, except for the intermediary rice price pair of Brazil-Uruguay, the domestic price reaches its new equilibrium after less than a year.

The impulse response functions also allow us to make comparisons among countries or markets. For example, Figure 4.12 (Annex 4.3) shows the impulse response functions for all intermediary and producer rice prices analyzed. The two graphs outline the stronger level of price transmission in Honduras and Brazil. It also shows how fixed prices, as in use in Costa Rica, can impede price transmission. The same can be seen for the maize market in Figure 4.13 (Annex 4.3). Here again, Brazil shows a more complete price transmission than other markets. Moreover, these figures show that in general, the intermediary prices reach a new equilibrium at a higher level than the producer prices.

\subsection{Conclusions}

The boom in commodity prices which took place in the recent years has raised a new interest in the issue of food security and of the necessity to restructure the agricultural sector. This has also led to an increased need to understand what variables and characteristics determine the evolution of prices. In this context, price transmission is one important element that influences the evolution of domestic prices and is therefore the topic of this paper.

The results of this paper show that all Central American domestic rice markets are integrated with the international Thai market. This can be explained by the influence that the Thai market can have on the USA market and hence on the Central American markets. This however is doubtful in the case of the intermediary market, since price transmission with the USA market does not seem existent. In Brazil, price transmission was found with the FOB prices of Argentina and Uruguay, which is consistent, since most of Brazil's rice imports come from these two countries.

In the maize market, the producer price of Panama and the intermediary price of Costa Rica show a high speed of adjustment and in the second case, a high elasticity of transmission. As for Chile and Brazil, the intermediary market is integrated with the Argentinean and USA international markets.

In general, the impulse response functions show evidence of particularly strong price transmission in the Brazilian and Chilean rice and maize markets. It also seems that price transmission is stronger in the reselling markets than in the producer markets and more complete in the rice than in the maize market. 
These results, jointly with the description of the agricultural policies of each country, show that in the large majority of cases, the absence of price transmission can be explained by (i) an excessive market power on the intermediaries' side or (ii) protective measures for the agricultural producer (a fixed price for example). Obviously, the latter are taken to counterbalance the former. However, both of them represent barriers to price transmission. Other policies which aim to improve the competitiveness of producers such as giving incentives to farmers to substitute the traditional low-productivity products with high-competitive exports ones (like exotic fruits for example), allow on the one hand the preservation and development of farming activities and on the other hand, better price transmission between markets.

However, if price transmission leads to a good allocation of resources in the long run, it also implies that price volatility is being passed on to producers in the short run. This first means higher income insecurity for the farmer. Second, it makes decision-taking more complicated, since the different crops' expected outcomes are harder to evaluate. Moreover, in the case of high volatility, farmers might be tempted to turn to low rentable but secure crops instead of competitive export crops, leading to a regression of the agricultural sector. In the extreme case, farmers might even decide to go back to subsistence farming, where price-linked risks disappear completely, but with all the disadvantages of subsistence farming. Hence, it is not enough to know the degree of price transmission among markets, we should also debate for which cases a higher or lower price transmission would be desirable and if governments should consider it as a goal.

\subsection{References}

Abdulai, A.; (2000). "Spatial Price Transmission and Asymmetry in the Ghanaian Maize Market". Journal of Development Economics, 63 pp 327-349.

Alemu, Z.G., \& G.R Biacuana; (2006). "Measuring Market Integration in Mozambican Maize Markets: A Threshold Vector Error Correction Approach”. paper presented at the International Association of Agricultural Economists Conference, Gold Cost, Austria.

Baffes, J., \& B. Gardner; (2003). "The Transmission of World Commodity Prices to Domestic Markets under Policy Reforms in Developing Countries”. Policy Reform, 6(3) pp 159-180.

Benavides, H., \& O. Segura; (2005). "El Entorno Internacional del Sector Arrocero Centroamericano". Instituto Centroamericano de Cooperación para la Agricultura (IICA).

Childs, N., \& A. Burdett; (2000). “The U.S. Rice Export Market”. Consultado 15 de Marzo 2009. (http://www.ers.usda.gov/briefing/Rice/SpecialArticle/USricemarket.pdf).

Conforti, P.; (2004). "Price Transmission in Selected Agricultural Markets". FAO Commodity and Trade Policy Research Working Paper, 7.

Corporación Arrocera Nacional (CONARROZ); (2008). “Informe Estadístico, Periodo 2007/2008”. San José, Costa Rica.

Cuéllar, J., \& D. Ramírez; (2009). "El Proceso de Liberalización Comercial y su Efecto Sobre el Mercado Centroamericano de Maíz: Un Análisis Espacial de Mercados”. CEPAL, Mexico. 
de Janvry, A., N. Key, \& E. Sadoulet; (1997). “Agricultural and Rural Development Policy in Latin America: New Directions and New Challenges". Department of Agricultural \& Resource Economics, UC Berkeley, Working Paper Series 815

Díaz, N., O. Melo, \& F. Modrego; (2007). "Dinámica de Transmisión de Precios y Cambios Estructural en el Sector Lácteo Chileno”. Economía Agraria, 11 pp 12-23.

Díaz, N., \& O. Melo; (2007). "Dinámica de Transmisión de Precios al Productor en el Sector Lácteo Chileno”. Mimeo. Pontificia Universidad Católica de Chile. Escuela de Agronomía. Chile.

Eberlin, R; (1998). "The Development Potential of the Nicaraguan Agricultural Sector under the Conditions of a Structural Adjustment Program. The Policy Analysis Matrix as a Methodological Instrument. An Empirical Application for the Case of Nicaragua (Central America)". Thesis to obtained the grade of Doctor of Technical Science (Diss ETH Nr. 12528), Swiss Federal Institute Of Technology, Zurich.

Ekboir, J., A. Pereira de Herrera, \& F. Becerra; (2003). “Análisis del Sistema Panameño de Investigación Agropecuaria”. Mexico, D.F.: CIMMYT.

Enders, W.; (1995). “Applied Econometric Time Series”. Wiley Series in Probability and Mathematical Statistics, John Wiley \& Sons, INC. pp 256-258

Engle, R., \& C. Granger; (1987) "Cointegration and Error Correction: Representation, Estimation and Testing", Econometrica, 55(2) pp 251-276.

Engler, A., \& L. Nahuelhual; (2008). "Implications of the Structural Change in Diary Products Trade on Mild Price paid to Producers in Chile". Chilean Journal of Agricultural Research, 69 pp 166-174.

Escobal, J., \& A. Vásquez; (2008). "Market Integration for Agricultural Output Markets in Peru: The Role of Public Infrastructure”. Quarterly Journal of International Agriculture, 47(1) pp 25-47.

Food and Agriculture Organization of the United Nations (FAO); (Consulting March 2009). "Base de Datos: FAOSTAT, Seguridad Alimentaria" (www.fao.org/faostat/foodsecurity/indexen.htm).

Food and Agriculture Organization of the United Nations (FAO); (Consulting March 2009). "FAO Statistical Yearbook 2007-2008”. ～(www.fao.org/economic/the-statistics-division-ess/publications-studies/statistical-yearbook/fao-statisticalyearbook-2007-2008/en/).

Fiess, N., \& D. Lederman; (2004). "Mexican Corn: The Effects of NAFTA”. WTO Trade Note.

Frey, G., \& M. Manera; (2007). "Econometric Models of Asymmetric Price Transmission”. Journal of Economic Surveys, 21(2) pp 349-415.

Giorgetti, M, S. Calvo, \& L. Salvador; (2007). "Un Análisis de la Integración Espacial de los Mercados de Soja y Maíz”. Revista Agriscientia, 24 (2) pp 79-85.

Goletti, F., R. Ahmed, \& N. Farid; (1995). "Structural Determinants of Market Integration: The Case if Rice Markets in Bangladesh”. The Developing Economies, 33 (2) pp 185-202.

Granger, C.W.J., \& T-H Lee; (1989). "Investigation of Production, Sales and Inventory Relationships Using Multicointegration and Non-Symmetric Error Correction Models”. Journal of Applied Econometrics, 4 pp 145-159.

Gregory, A.W., \& B.E. Hansen; (1996). "Residual Based Tests for Cointegration in Models With Regime Shifts". Journal of Econometrics, 70(1) pp 99-126.

Hamilton, J.D.; (1994). “Time Series Analysis”. Princeton University Press, Princeton, New Yersey.

Hendry, D.F., \& K. Juselius; (2000). “Explaining Cointegration Analysis: Part I”. The Energy Journal, 21(1) pp 1-42. 
Honaker, J., G. King, \& M. Blackwell; (2009). “Amelia II: A Program for Missing Data. Version 1.5-5”, The R Project for Statistical Computing (http://cran.r-project.org/web/packages/Amelia/vignettes/amelia.pdf)

Istiqomah, M. Zeller, \& S. Von Cramon-Taubadel; (2005). "Volatility and Integration of Rice Markets in Java, Indonesia: A Comparative Analysis before and after Trade Liberalization". paper presented at the Conference on International Agricultural Research for Development, Stuttgart-Hohenheim, Germany.

Jansen, H.G. P., J. Pender, A. Damon, \& R. Schipper; (2007). "Políticas de Desarrollo Rural y Uso Sostenible de la Tierra en las Zonas de Ladera de Honduras. Un Enfoque Cuantitativo de los Medios de Vida”. IFPRI, Washington D.C.

Johansen, S.; (1988). "Statistical Analysis of Cointegration Vectors". Journal of Economics Dynamics and Control, 12(2-3) pp 231-254.

Lütkephol, H., \& M. Krtzip; (2006). "Initial Analysis in JMulTi”. Projects JmulTi-Time Series Analysis with Java. (http://www.jmulti.de/download/help/initanal.pdf).

Maddala, G.S., \& K. In-Moon; (2004). 'Unit Roots, Cointegration and Structural Change”. Cambridge University Press.

Margarido, M.A., \& L.A Lima; (2009). "Transmission of External and Domestic Prices to Farm Prices in Brazil: a Simulation". Mimeo.

Meyer, J., \& S. von Cramon-Taubadel; (2004). “Asymmetric Price Transmission: A Survey". Journal of Agricultural Economics, 50(3) pp 581-611.

Mundlak, Y., \& D.F. Larson; (1992). "On the Transmission of World Agricultural Prices”. The World Bank Economic Review, 6(3) pp 399-422.

Perron, P.; (1989). "The Great Crash, the Oil Price Shock, and the Unit Root Hypothesis". Econometrica, 57(6) pp 13611401.

Phillips, P.C.B, \& S. Ouliaris; (1990). “Asymptotic Properties of Residual Based Tests for Cointegration”. Econometrica, 58(1) pp 165-193.

Pingali, P.L; (2001). “CIMMYT 1999-2000 World Maize Facts and Trends. Meeting World Maize Needs: Technological Opportunities and Priorities for the Public Sector”. Mexico, D.F.: CIMMYT.

Ravallion, M.; (1986). “Testing Market Integration”. American Journal of Agricultural Economics, 68 (1) pp 102-109.

Sanint, L., F. Correa-Victoria, \& J. Izquierdo; (1998). "The Current Situation and Issues on Rice Production in Latin America and the Caribbean". paper presented at 19th Session of the International Rice Commission, Cairo, Egypt.

Sarris, A., \& E. Mantsou; (2005). "Linkages Between Domestic and International Maize Markets, and Market Based Strategies for Hedging Maize Import Price Risks in Tanzania". FAO Commodity and Trade Policy Research. Working Paper 14.

Secretaría de Agricultura y Ganadera (SAG); (2002). “Mesa Agrícola Hondureña: Arroz”. Tegucigalpa, Honduras.

Secretaría de Integración Economica Centroamericana (SIECA); (2009). "Evolución del Comercio Centroamérica -Estados Unidos en el Marco del DR -CAFTA". Guatemala.

von Cramon-Taubadel, S.; (1998). "Estimating Asymmetric Price Transmission with the Error Correction Representation: An Application to the German Pork Market”. European Review of Agricultural Economics, 25(1) pp 1-18.

Zivot, E., \& D.W.K. Andrews; (1992). "Further Evidence on the Great Crash, the Oil Price Shock, and the Unit Root Hypothesis". Journal of Business \& Economic Statistics, 10(3) pp 251-270. 


\section{Annex 4.1}

\section{Number of Observations and Time Span in each Price Relationship}

Table 4. 5

Number of Observations and Time Span of each Price

Relationship

\begin{tabular}{|c|c|c|c|c|c|c|}
\hline \multirow{2}{*}{ Pair of prices } & \multicolumn{3}{|c|}{ Intermediaries } & \multicolumn{3}{|c|}{ Producer } \\
\hline & Beginning & End & \# Observations & Beginning & End & \#Observations \\
\hline \multicolumn{7}{|l|}{ Rice } \\
\hline E1 Salvador Thailand & $2001 \mathrm{~m} 3$ & $2008 \mathrm{~m} 10$ & 91 & & & \\
\hline E1 Salvador US & $2001 \mathrm{~m} 3$ & $2008 \mathrm{~m} 10$ & 91 & & & \\
\hline Honduras Thail and & $2001 \mathrm{~m} 8$ & $2008 \mathrm{~m} 10$ & 86 & $1985 \mathrm{~m} 2$ & $1996 \mathrm{~m} 5$ & \\
\hline Honduras US & $2001 \mathrm{~m} 8$ & $2008 \mathrm{~m} 10$ & 86 & $1989 \mathrm{~m} 10$ & $1996 \mathrm{~m} 5$ & 68 \\
\hline Guatemala Thailand & $2001 \mathrm{~m} 3$ & $2008 \mathrm{~m} 10$ & 91 & & & \\
\hline Guatemala US & $2001 \mathrm{~m} 3$ & $2008 \mathrm{~m} 10$ & 91 & & & \\
\hline Nicaragua Thailand & $2001 \mathrm{~m} 3$ & $2008 \mathrm{~m} 10$ & 91 & $1991 \mathrm{~m} 1$ & $2008 \mathrm{~m} 1$ & 205 \\
\hline Nicaragua US & $2001 \mathrm{~m} 3$ & $2008 \mathrm{~m} 10$ & 91 & $1991 \mathrm{~m} 1$ & $2008 \mathrm{~m} 1$ & 205 \\
\hline Panama Thailand & $2001 \mathrm{~m} 3$ & $2008 \mathrm{~m} 10$ & 91 & $1994 \mathrm{~m} 1$ & $2005 \mathrm{~m} 4$ & 136 \\
\hline Panama US & $2001 \mathrm{~m} 3$ & $2008 \mathrm{~m} 10$ & 91 & $1994 \mathrm{~m} 1$ & $2005 \mathrm{~m} 4$ & 136 \\
\hline Brazil Thailand & $1999 \mathrm{~m} 10$ & $2008 \mathrm{~m} 10$ & 121 & $1999 \mathrm{~m} 10$ & $2008 \mathrm{~m} 10$ & 109 \\
\hline Brazil Argentina & $1999 \mathrm{~m} 10$ & $2008 \mathrm{~m} 12$ & 123 & $1999 \mathrm{~m} 10$ & $2008 \mathrm{~m} 12$ & 113 \\
\hline Brazil Uruguay & $1999 \mathrm{~m} 10$ & $2008 \mathrm{~m} 12$ & 123 & $1999 \mathrm{~m} 10$ & $2008 \mathrm{~m} 12$ & 113 \\
\hline Chile Thailand & $1985 \mathrm{~m} 1$ & $2007 \mathrm{~m} 11$ & 155 & & & \\
\hline Chile US & $1989 \mathrm{~m} 10$ & $2007 \mathrm{~m} 11$ & 218 & & & \\
\hline Chile Argentina & $1999 \mathrm{~m} 10$ & $2007 \mathrm{~m} 11$ & 98 & & & \\
\hline Chile Uruguay & $1999 \mathrm{~m} 10$ & $2007 \mathrm{~m} 11$ & 98 & & & \\
\hline Costa Rica Thailand & $1999 \mathrm{~m} 9$ & $2008 \mathrm{~m} 10$ & 110 & $1999 \mathrm{~m} 8$ & $2008 \mathrm{~m} 10$ & 111 \\
\hline Costa Rica US & $1999 \mathrm{~m} 9$ & $2008 \mathrm{~m} 12$ & 112 & $1999 \mathrm{~m} 8$ & $2008 \mathrm{~m} 12$ & 113 \\
\hline \multicolumn{7}{|l|}{ Maize } \\
\hline Guatemala US & $1994 \mathrm{~m} 1$ & $2008 \mathrm{~m} 10$ & 178 & & & \\
\hline Panama US & $1994 \mathrm{~m} 1$ & $2008 \mathrm{~m} 10$ & 178 & $1994 \mathrm{~m} 1$ & $2006 \mathrm{~m} 12$ & 156 \\
\hline Brazil US & $1988 \mathrm{~m} 1$ & $2008 \mathrm{~m} 10$ & 250 & $1985 \mathrm{~m} 1$ & $2008 \mathrm{~m} 1$ & 276 \\
\hline Brazil Argentina & $1988 \mathrm{~m} 1$ & $2008 \mathrm{~m} 10$ & 250 & $1988 \mathrm{~m} 1$ & $2008 \mathrm{~m} 1$ & 241 \\
\hline Chile US & $1988 \mathrm{~m} 1$ & $2007 \mathrm{~m} 11$ & 239 & & & \\
\hline Chile Argentina & $1988 \mathrm{~m} 1$ & $2007 \mathrm{~m} 11$ & 239 & & & \\
\hline Costa Rica US & $1997 \mathrm{~m} 1$ & $2008 \mathrm{~m} 10$ & 142 & & & \\
\hline
\end{tabular}




\section{Annex 4.2}

\section{Data Figures}

Figure 4. 4

Log of Rice Prices: Honduras and International Prices

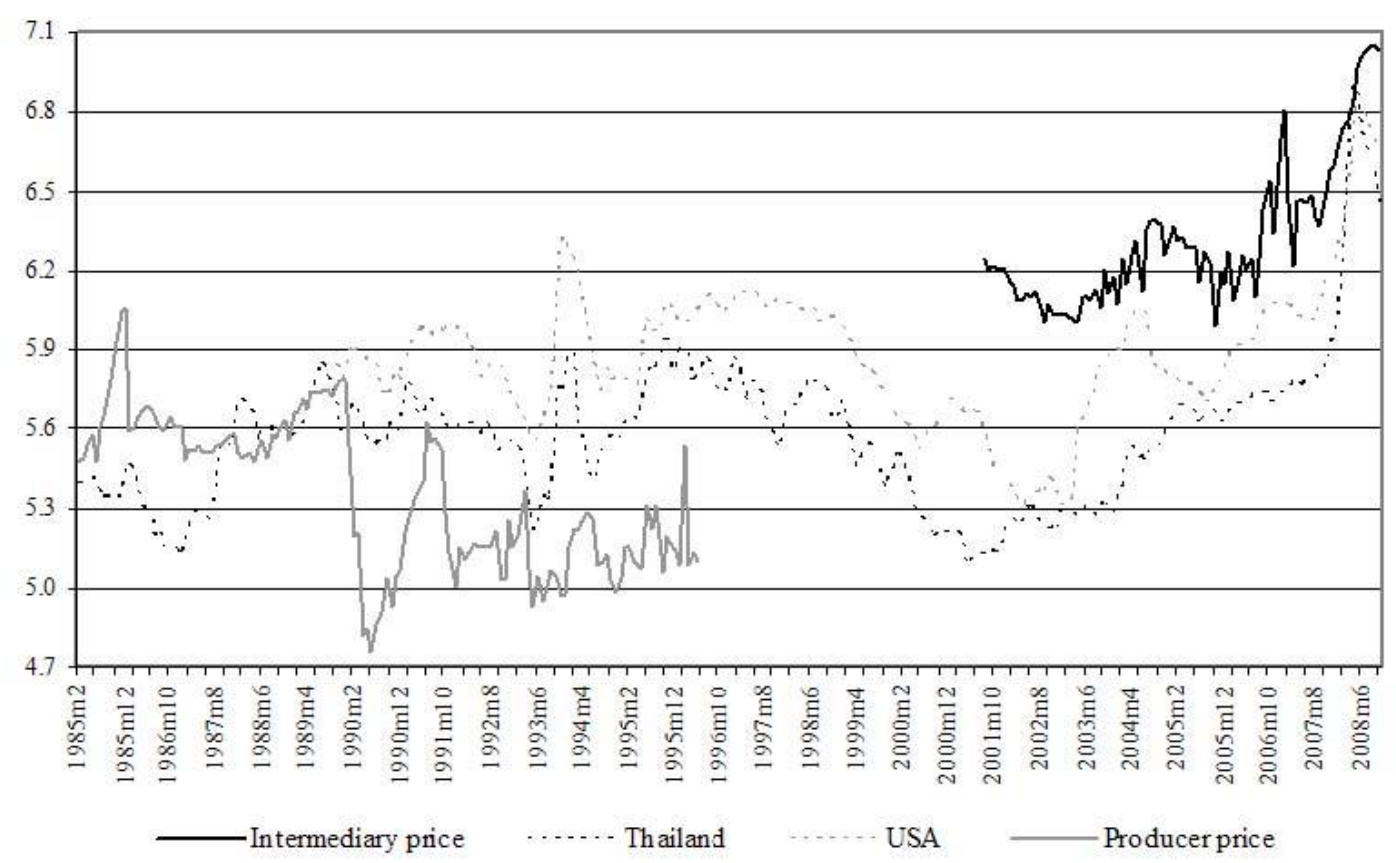

Source: Author's Elaboration. Data: ECLAC, CORECA, IMF, USDA. 
Figure 4. 5

Log of Rice Prices: Guatemala and International Prices

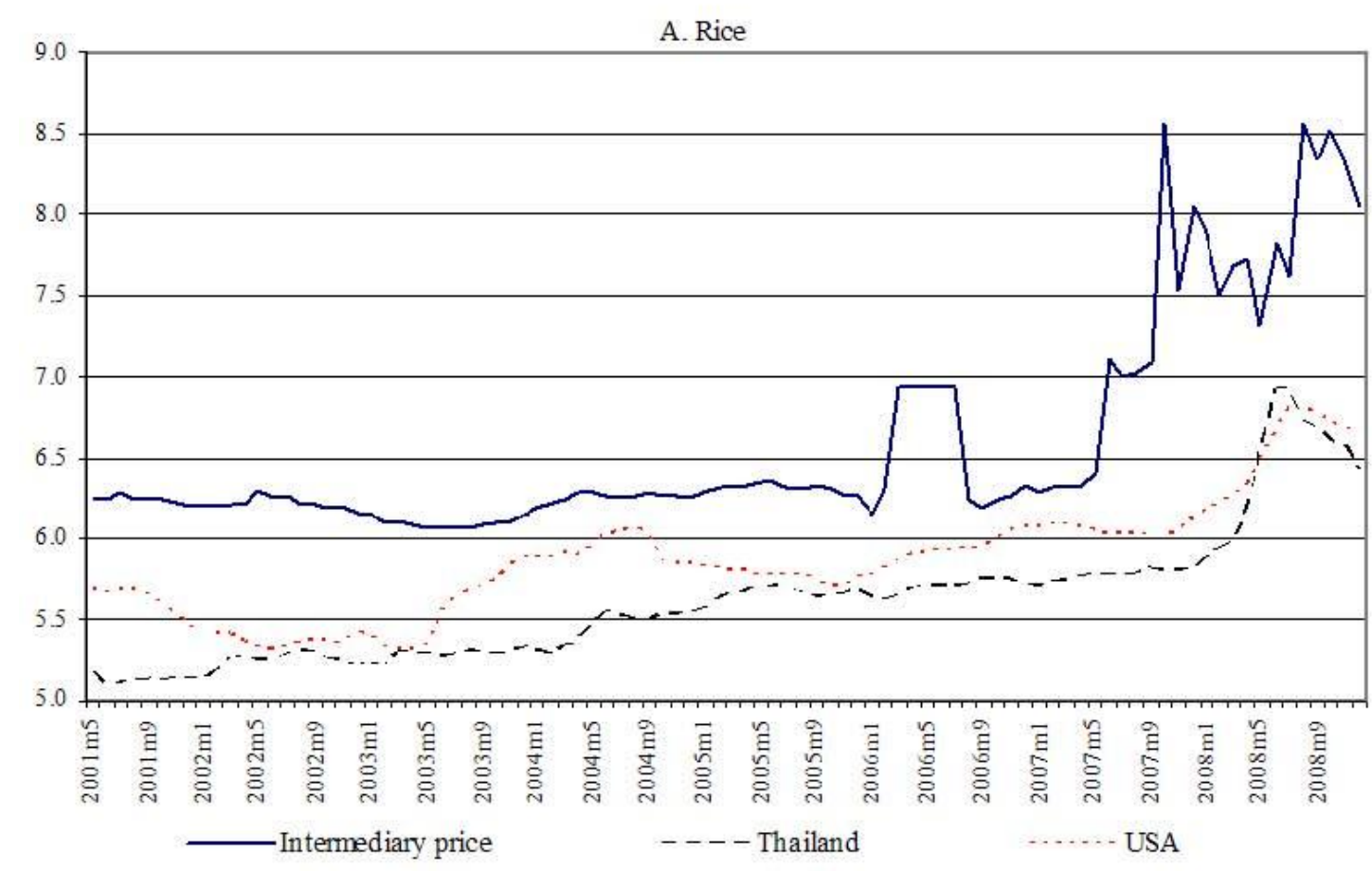

B. Maize

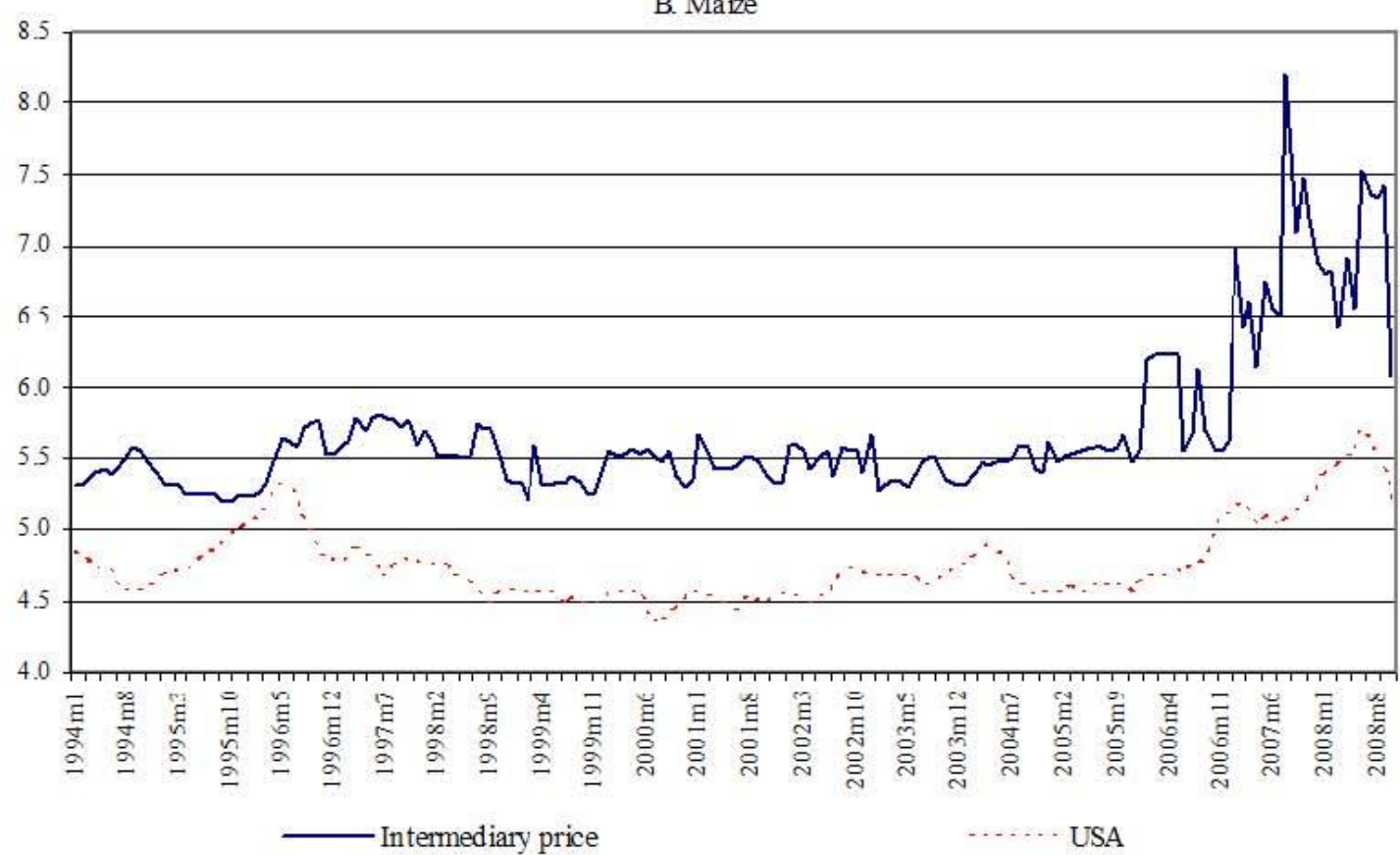

Source: Author's Elaboration. Data: ECLAC, CORECA, ICG, IMF, USDA. 
Figure 4. 6

Log of Rice Prices: El Salvador and International Prices

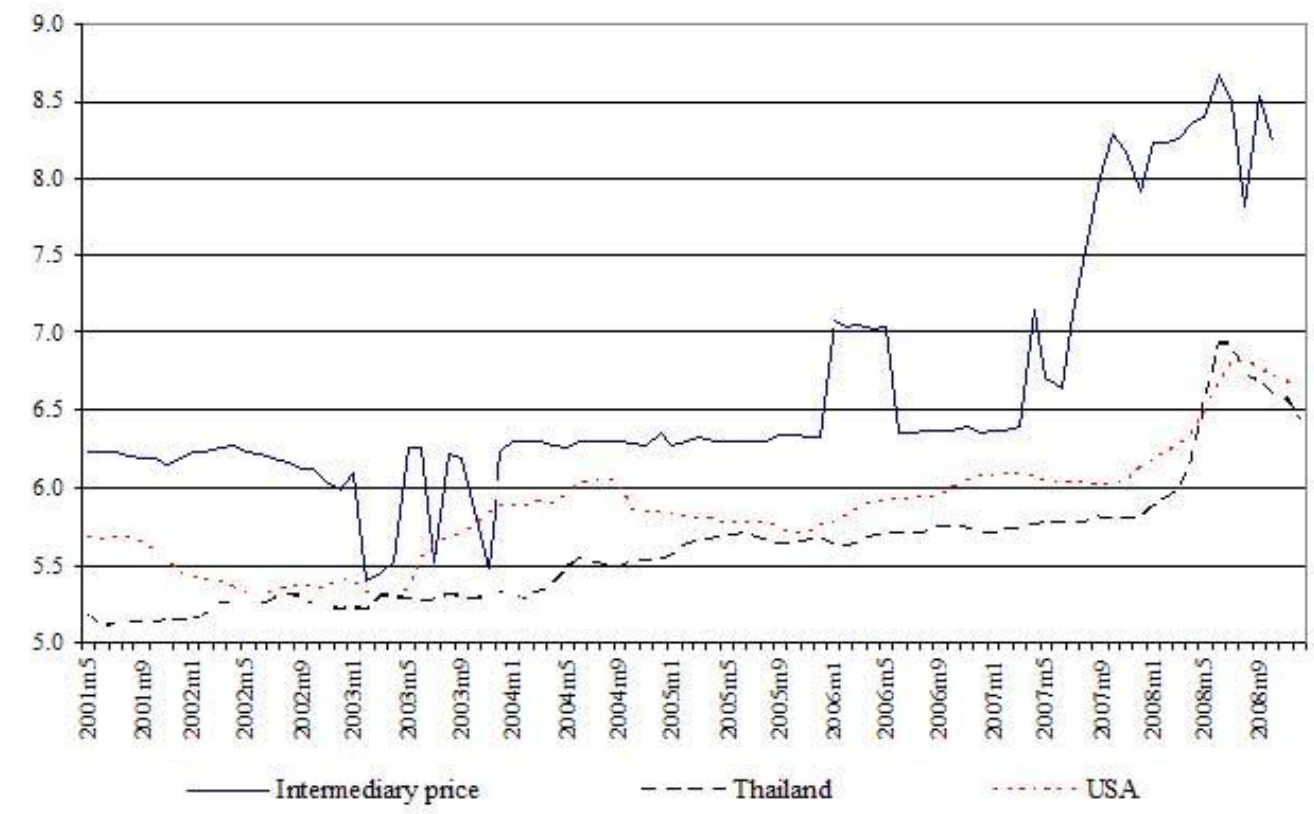

Source: Author's Elaboration. Data: ECLAC, CORECA, ICG, IMF, USDA.

Figure 4. 7

Log of Rice Prices: Nicaragua and International Prices

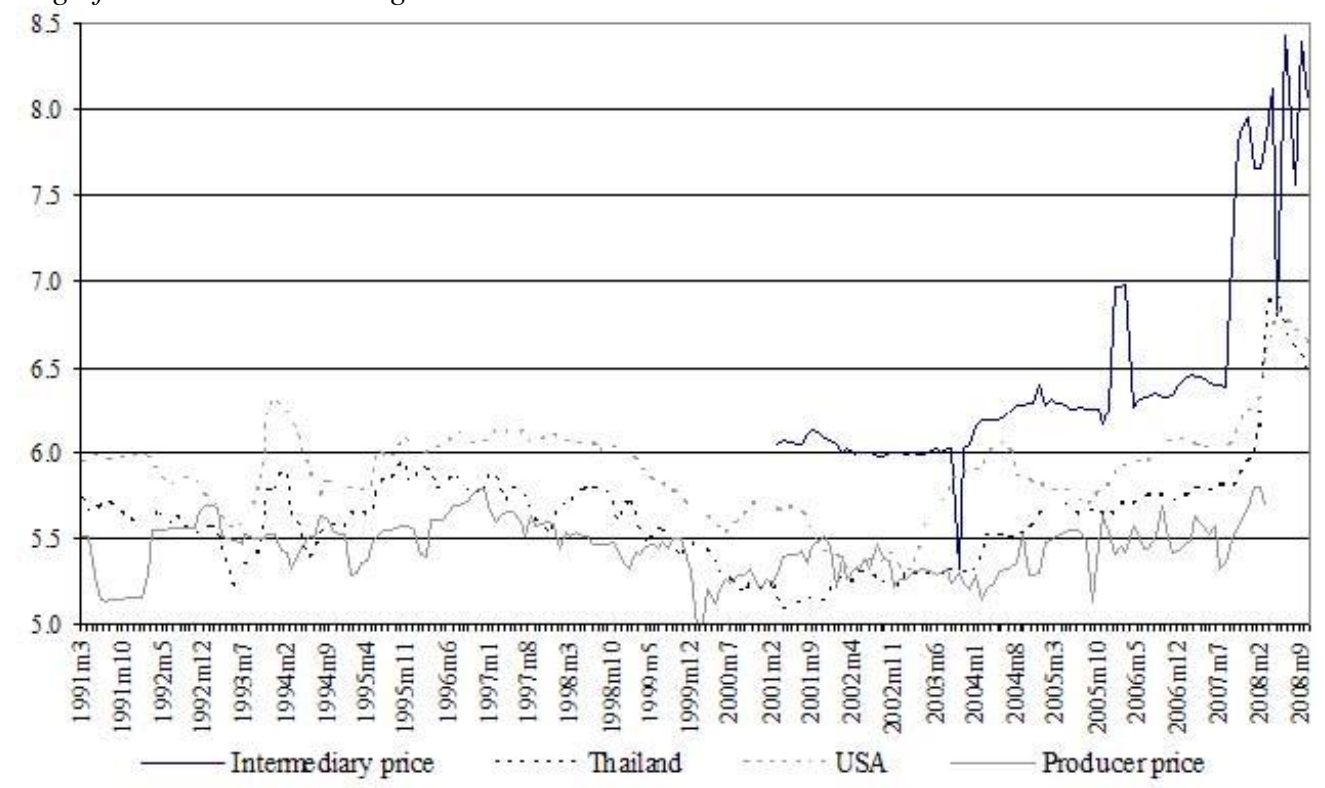

Source: Author's Elaboration. Data: ECLAC, CORECA, ICG, IMF, USDA. 
Figure 4. 8

Log of Rice Prices: Panama and International Prices

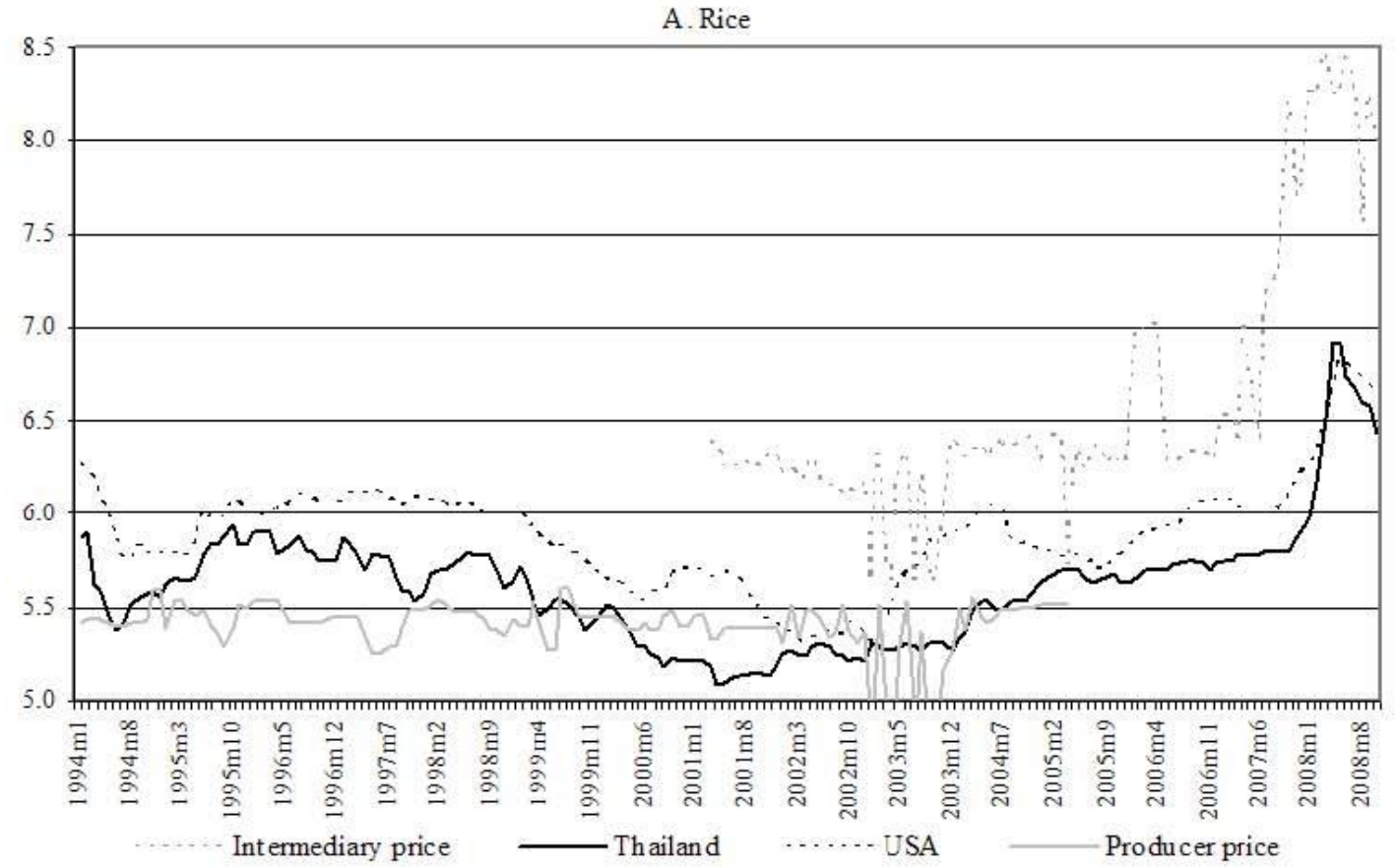

B. Maize

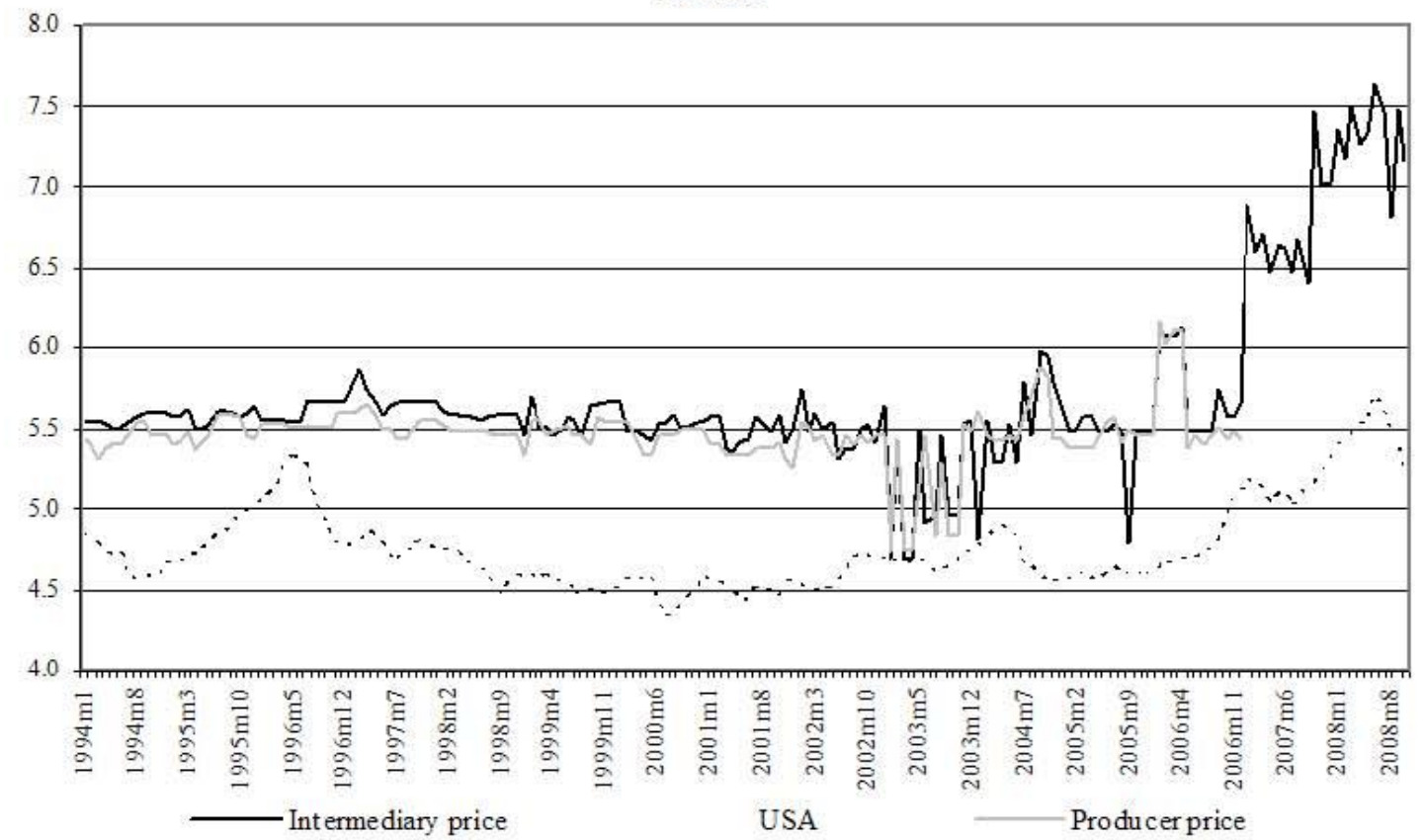

Source: Author's Elaboration. Data: ECLAC, CORECA, ICG, IMF, USDA. 
Figure 4.9

Log of Rice Prices: Costa Rica and International Prices

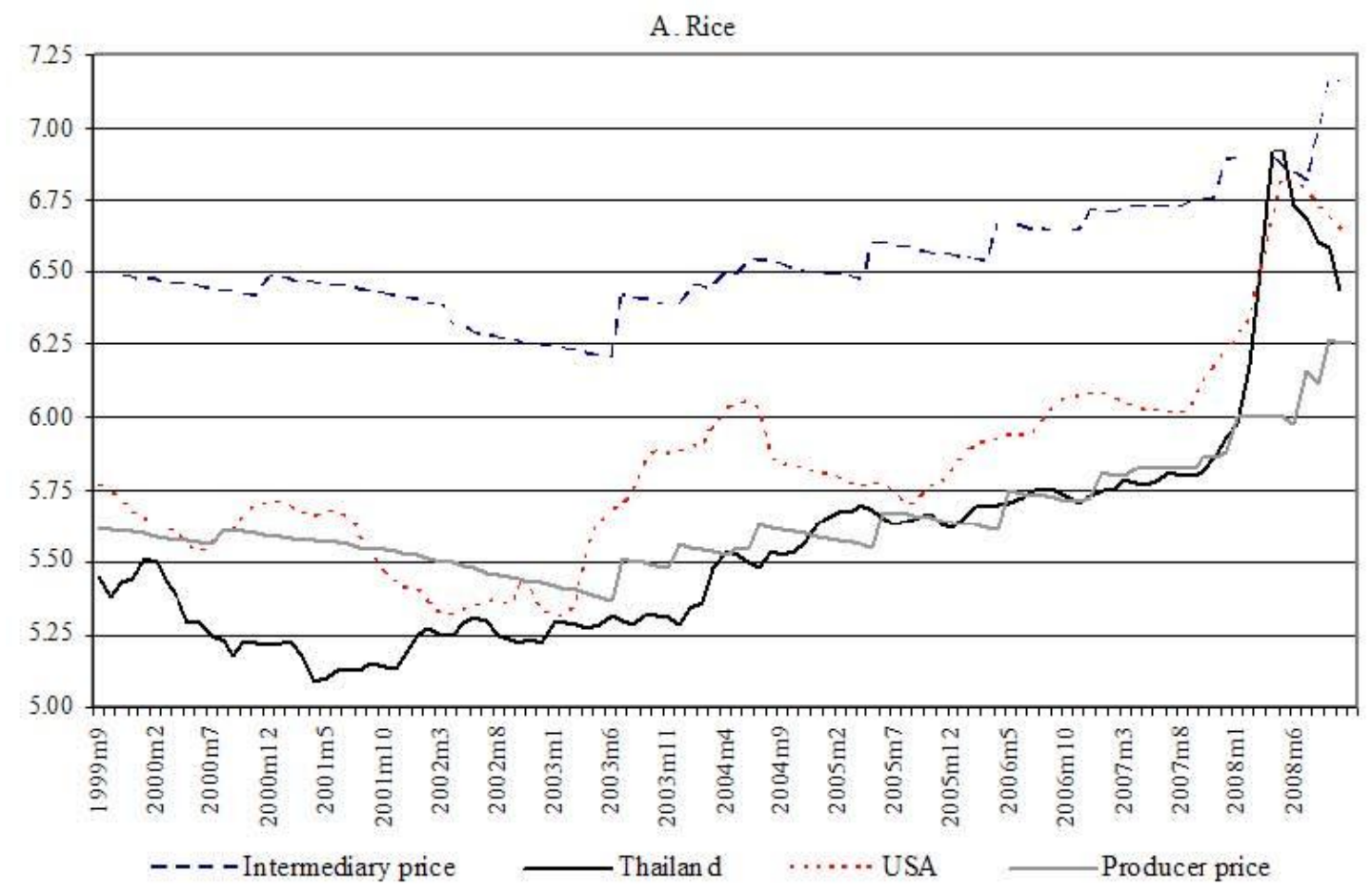

B. Maize

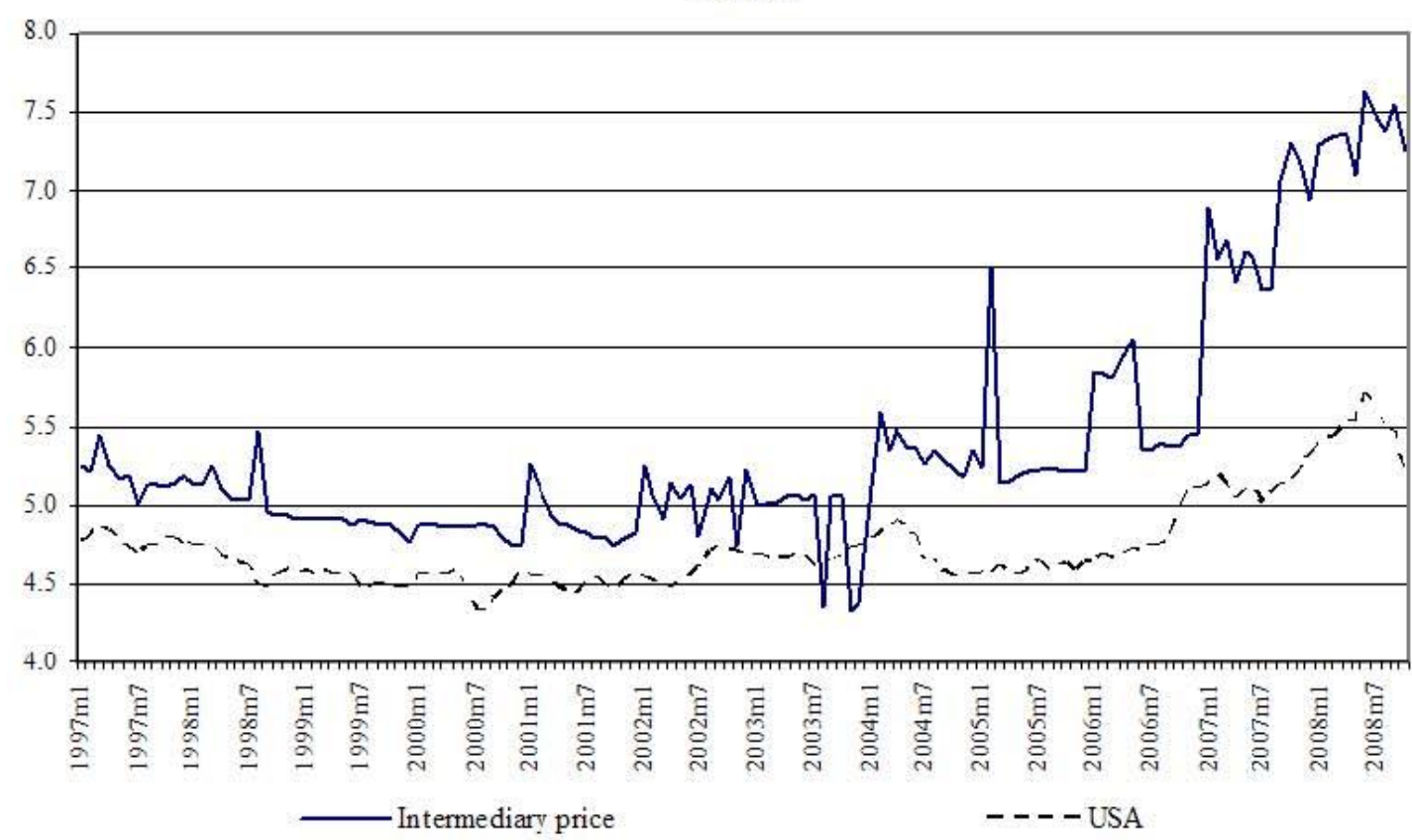

Source: Author's Elaboration. Data: ECLAC, CONARROZ, ICG, IMF, USDA. 
Figure 4. 10

Log of Rice Prices in Brazil and International Prices

A. Rice

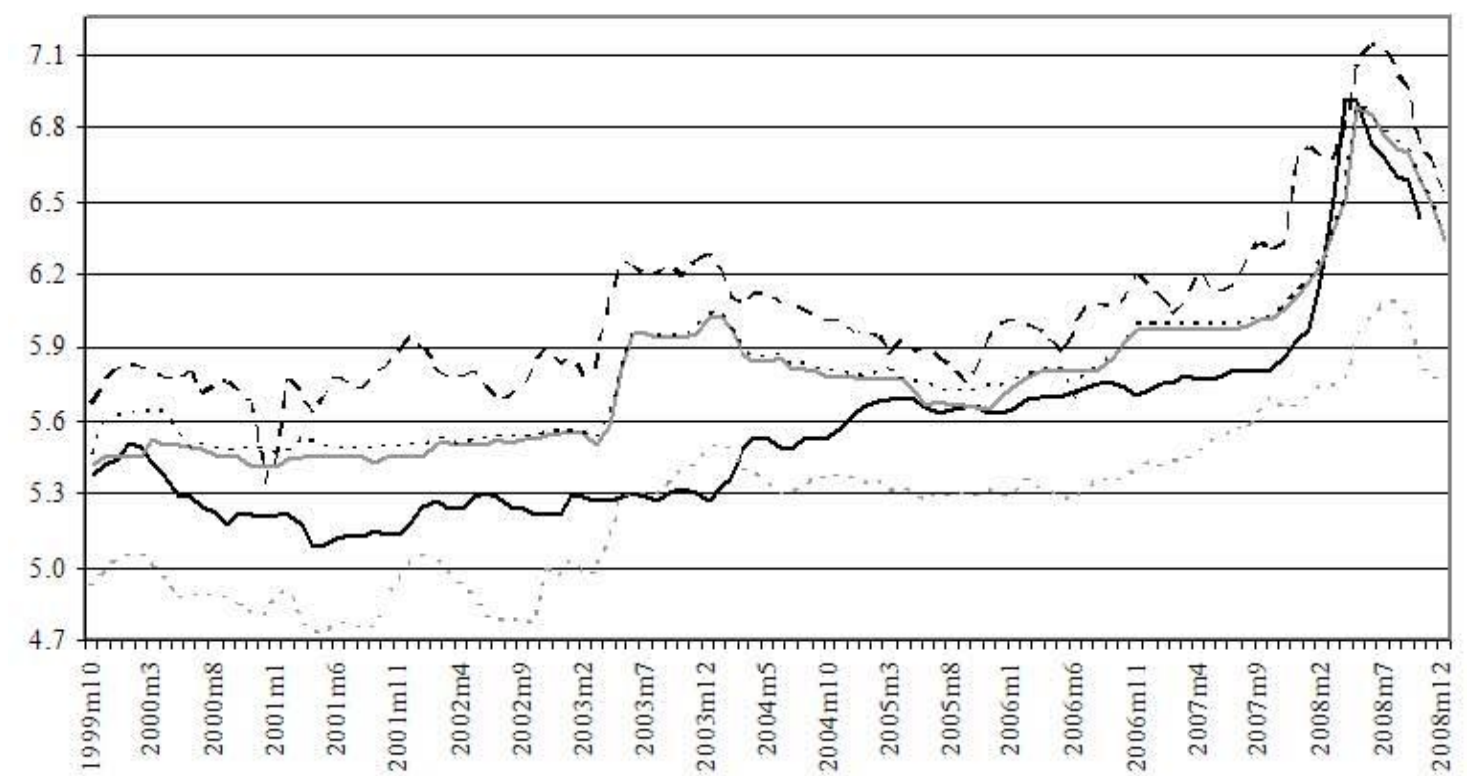

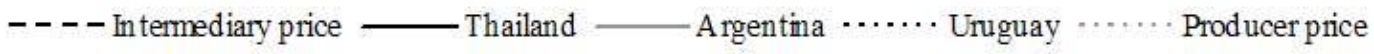

B. Maize

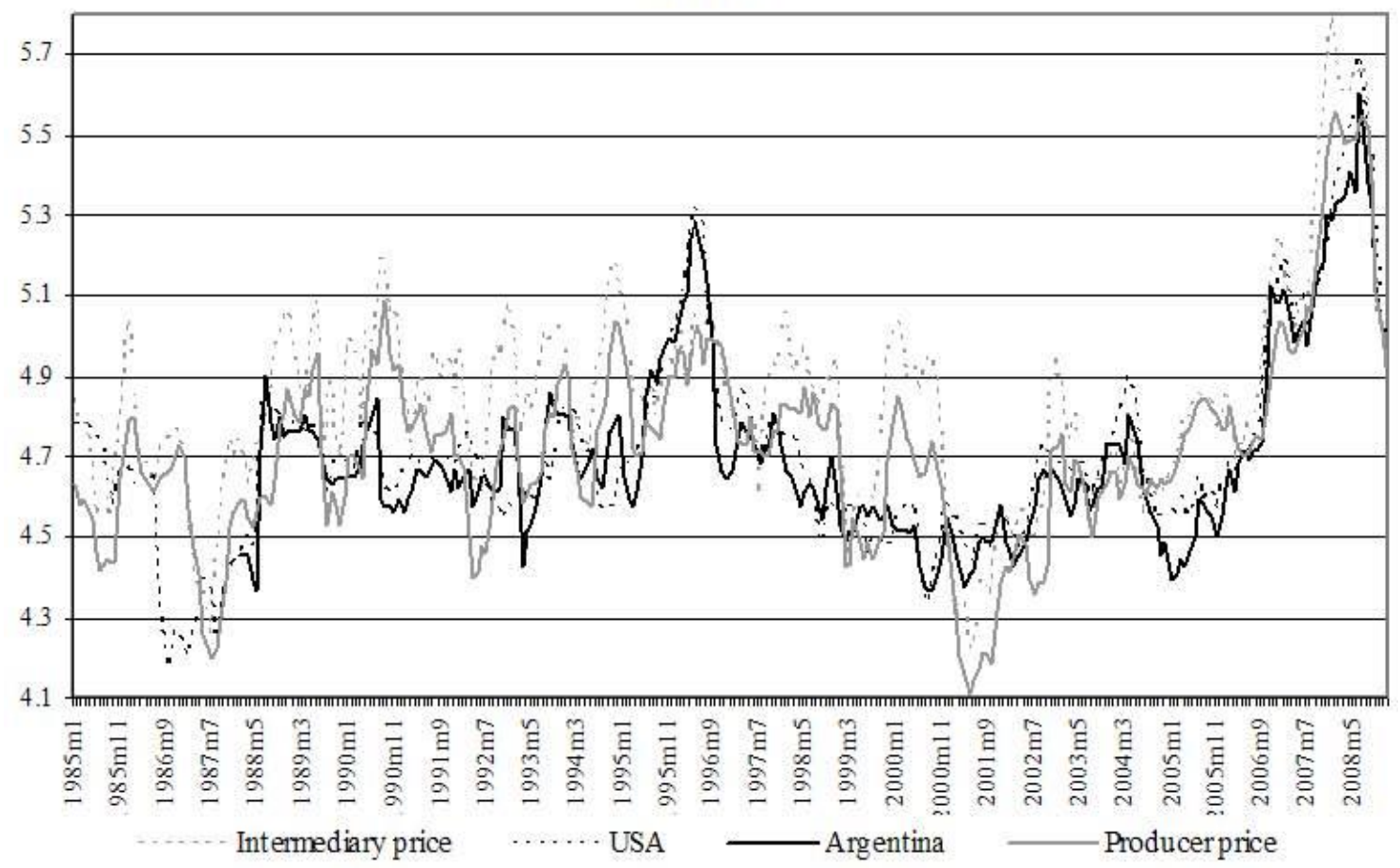

Source: Author's Elaboration. Data: ECLAC, ICG, IMF, USDA. 
Figure 4. 11

Log of Rice Prices: Chile and International Prices

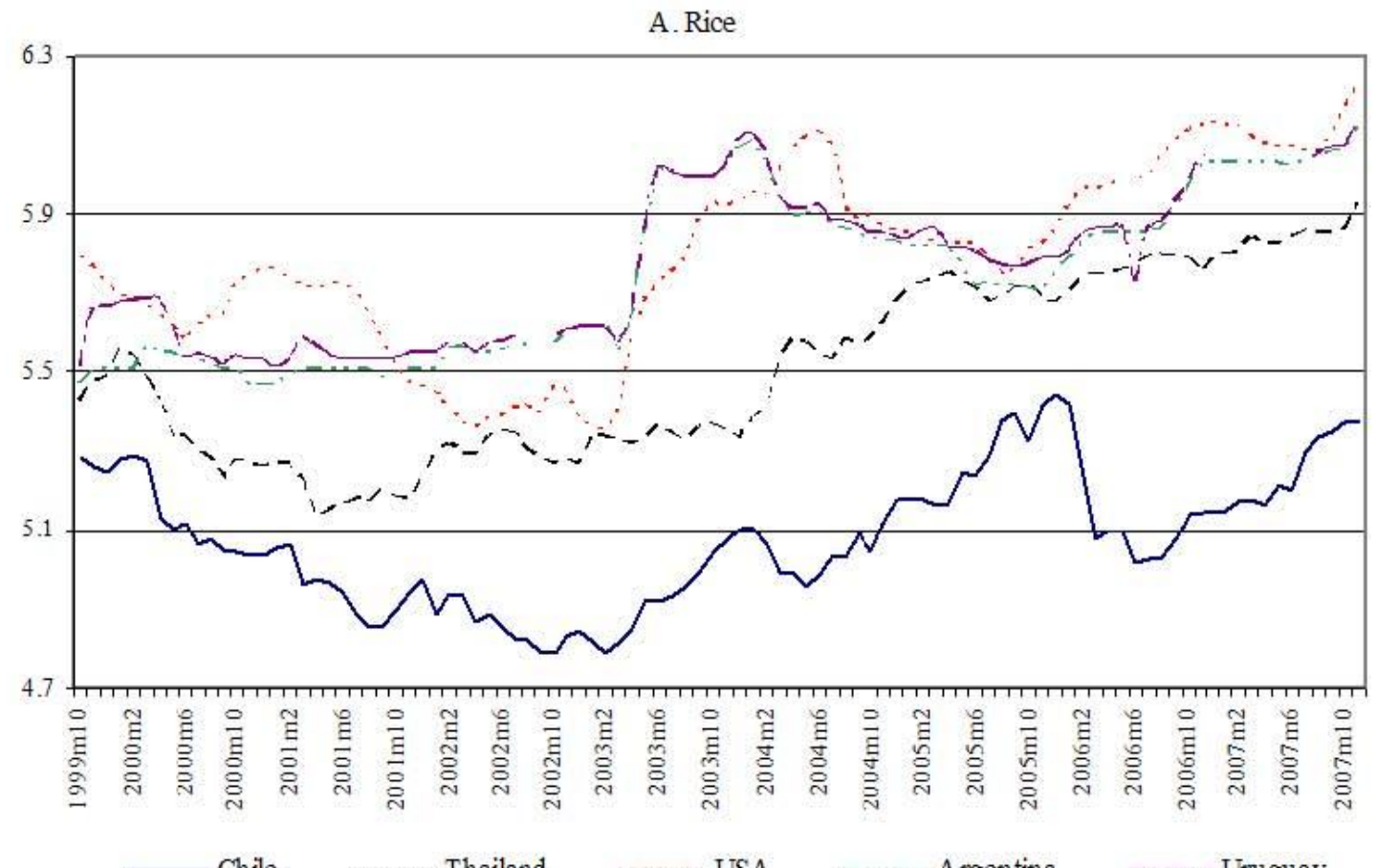

Chile $\quad----$ Thailand

USA

- Argentina

----Uruguay

B. Maize

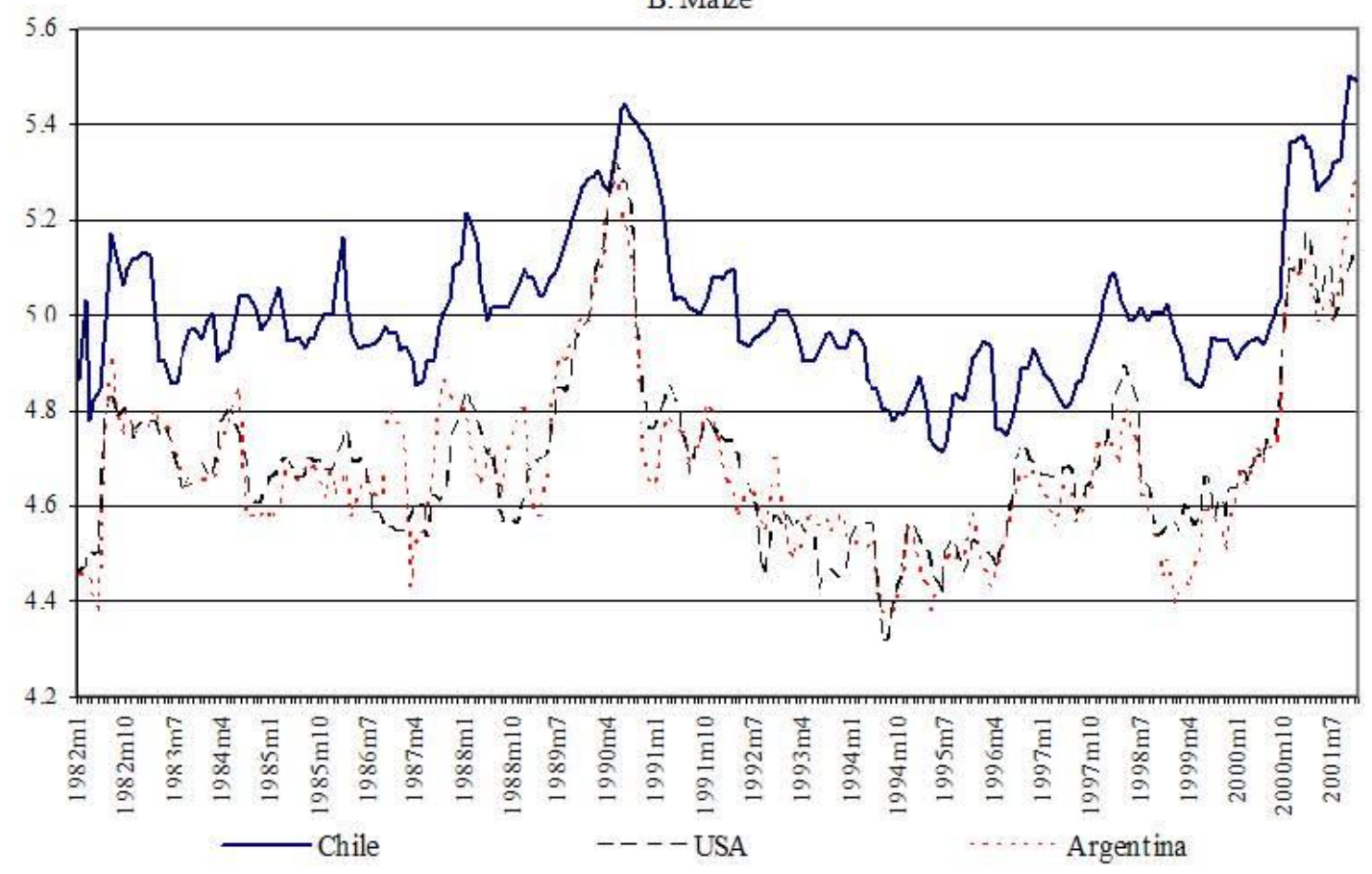

Source: Author's Elaboration. Data: ECLAC, ICG, IMF, ODEPA, USDA. 


\section{Annex 4.3}

\section{Impulse Response Function}

The impulse response function, which represents the response of the national price to a shock in the international price, is based in the long run equation (3.1) (in the presences of structural break equations (3.2.1), (3.2.2) or (3.2.3) ) and in the short run equations (3.3.1) and (3.3.2) of the ECM.

Firstly, as starting point of the simulation an initial level of prices is selected. Following the methodology applied by Díaz and Melo (2007), where the international base price is the average price of the sample

$\bar{P}^{x}=\sum_{t=0}^{T} \frac{1}{T} P_{t}^{x}$

Substituting in the long run equation the value of $P_{t}^{x}$ for $P^{x}$ the national starting price $\bar{P}^{Y}$ is found.

A shock, which corresponds to 2 standard deviations of the international price, is applied to the international base price.

Recalling that $E C T_{t}=P_{t}^{y}-\beta_{1} P_{t}^{x}$, the shock's impact for each month is estimated replacing the $E C T_{t-1}$ and the changes in prices in the short run equation.

For example, the effect in the first period of a shock equal to $\Delta$ in the period 0 is:

$$
\begin{aligned}
& \Delta P_{1}^{y}=\alpha_{y} E C T_{0}+\sum_{j=1}^{n_{x}} \Gamma_{j}^{y} \Delta+\sum_{j=1}^{n_{y}} \Gamma_{j}^{x} 0+\delta_{i} D_{i}+\varepsilon_{1}^{y} \\
& \Delta P_{1}^{x}=\alpha_{x} E C T_{0}+\sum_{j=1}^{m_{x}} \Phi_{j}^{y} \Delta+\sum_{j=1}^{m_{y}} \Phi_{j}^{x} 0+\delta_{i} D_{i}+\varepsilon_{1}^{x}
\end{aligned}
$$

Where, $E C T_{0}=\bar{P}^{y}+\beta\left(\bar{P}^{x}+\Delta\right)$

For ease of comparison, the graphical results were modified to have all the curves in the following figures started in 0 . Therefore, the figures show that, instead of starting in the average value, the national price starts the adjustment in cero. 
Figure 4. 12

IRF, Rice Markets
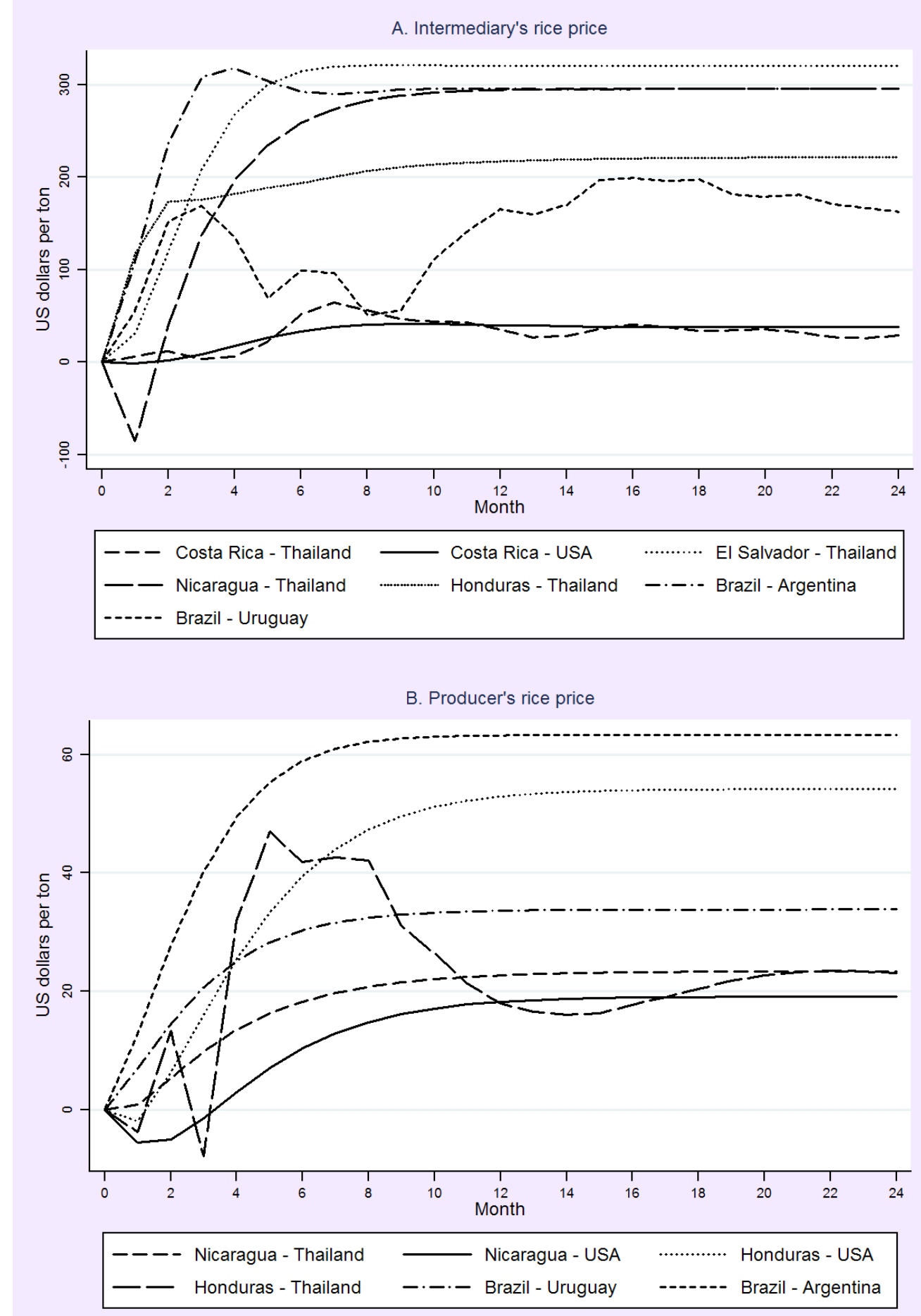

Source: Author's Elaboration. 
Figure 4. 13

IRF, Maize Markets
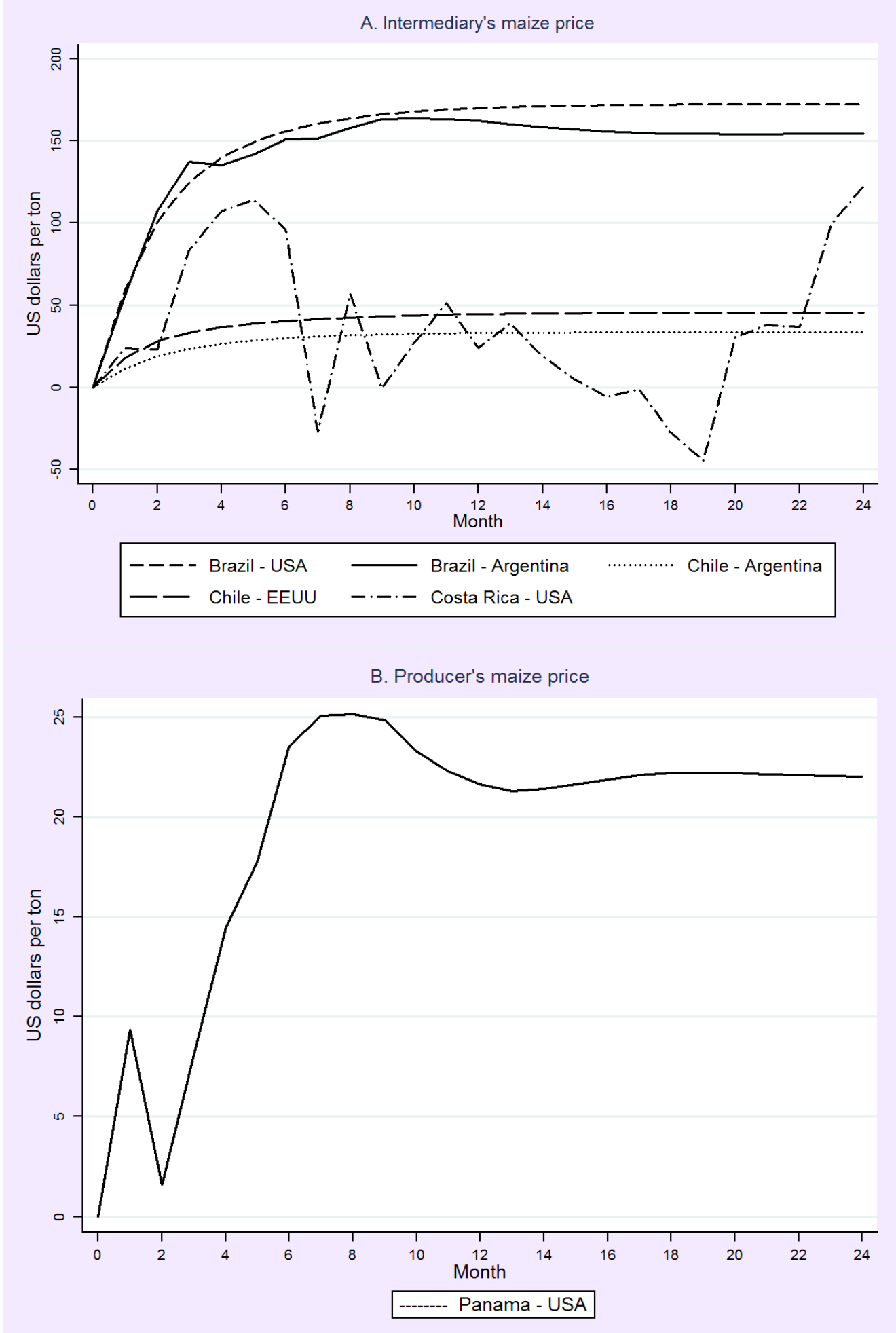

Source: Author’s Elaboration. 
Figure 4. 14

IRF, Nicaragua Rice Market

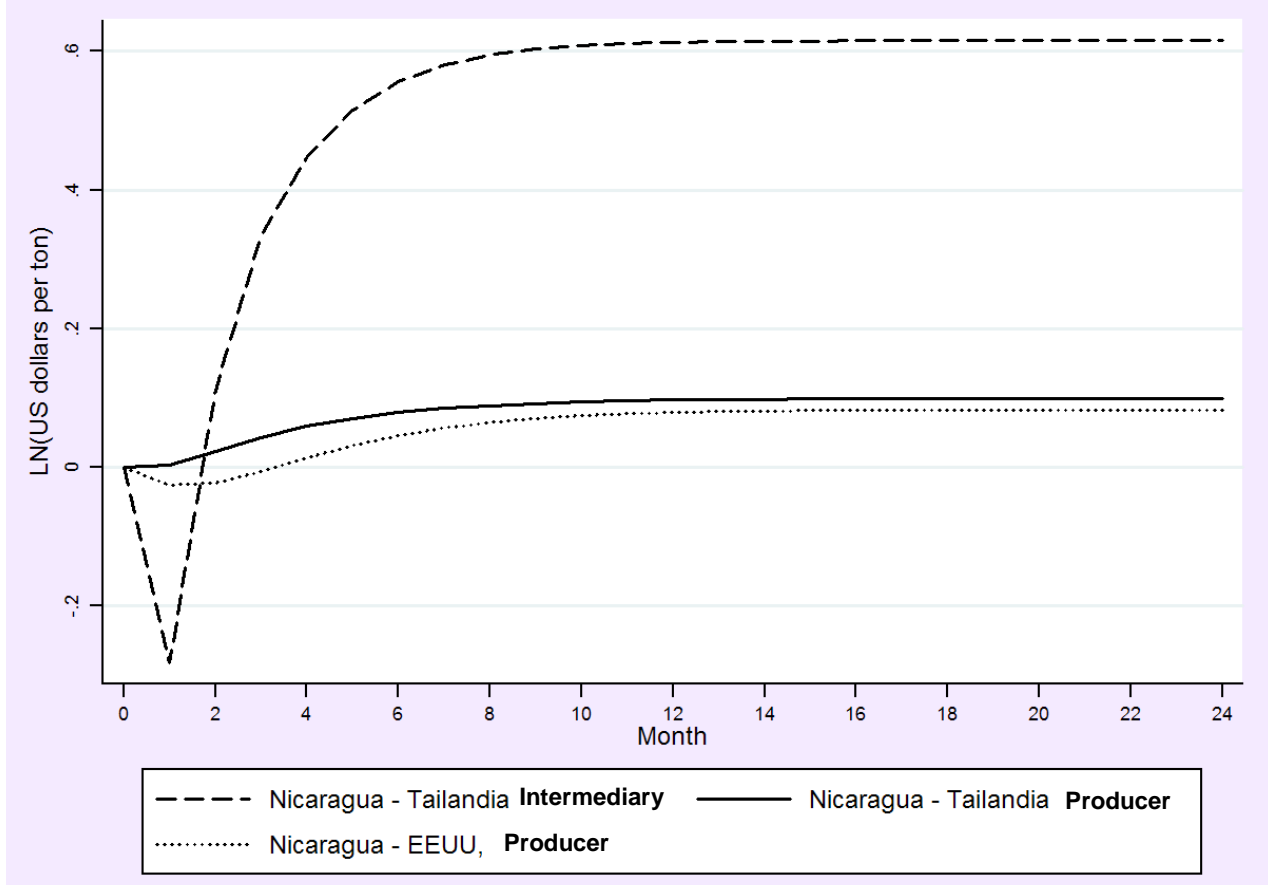

Source: Author's Elaboration.

Figure 4. 15

IRF, Maize Intermediary Market, Chile

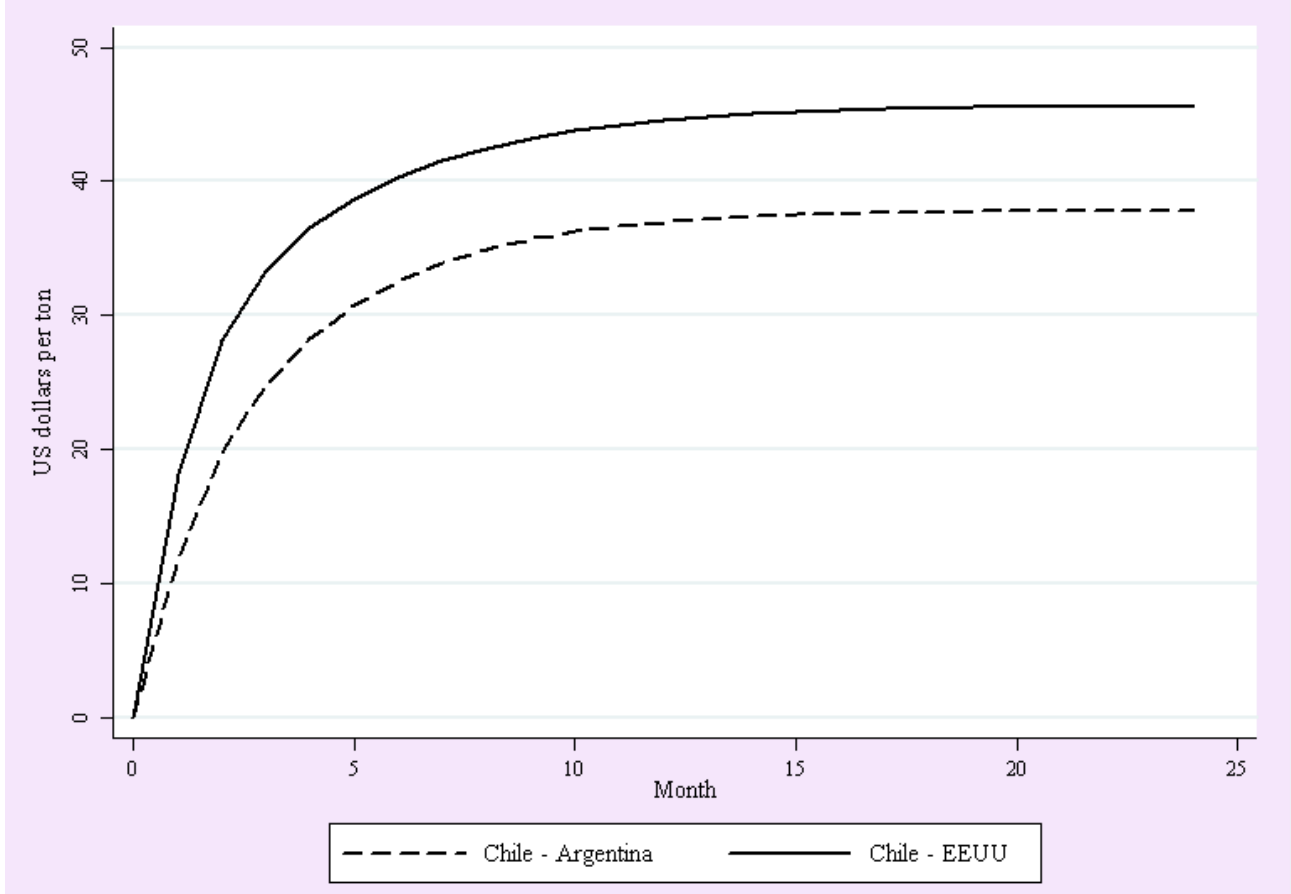

Source: Author's Elaboration. 
Figure 4. 16

IRF, Maize and Rice Market, Brazil

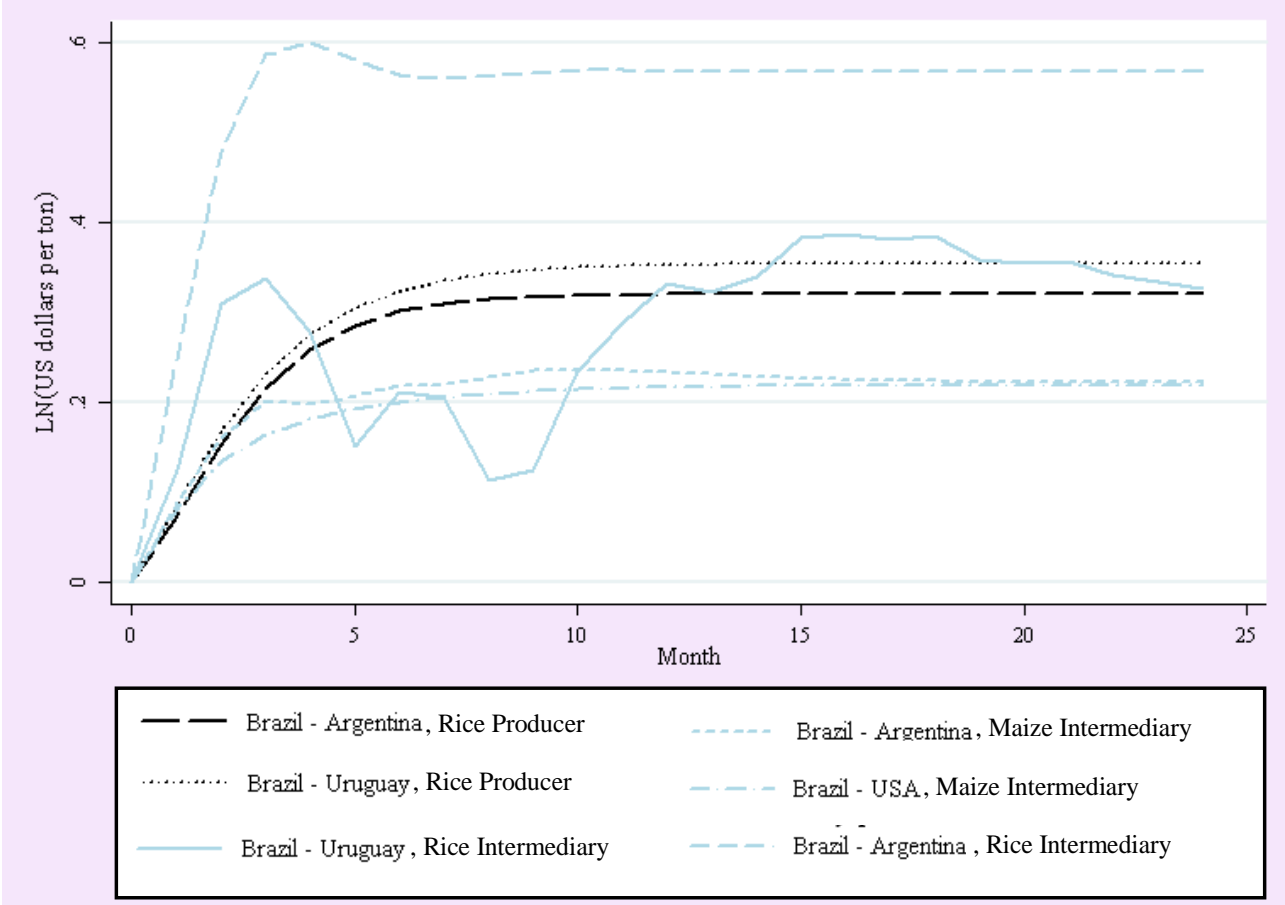

Source: Author's Elaboration. 


\section{Chapter 5}

\section{The Relationship between Spatial Integration and Geographical Distance in Brazil}

\subsection{Introduction}

Within the analysis of market integration the Law of One Price (LOP), derived from the concept of spatial arbitrage, plays a significant role and has been deeply investigated. It argues that the prices of an identical product in two spatially separate markets will differ just by an amount less than or equal to transfer costs (Enke, 1951, cited by Rapsomanikis et al., 2003). However, results of integration analysis using the cointegration framework indicate that some market prices do not fulfill this perfect relationship. Pertaining to that, Fackler and Goodwin (2001) explain market integration as a measure of the degree of a relationship and not a dichotomic outcome, which means a scale from completely separate markets to perfect market integration, where the LOP is implied last. This degree can also be described as the spatial market integration measurement. This measurement reflects the smooth transmission of price signals and information across spatially separate markets and has long been considered an important indicator of performance which provides insights into market efficiency (Rapsomanikis et al., 2003). In addition, spatial integration makes the identification of markets conglomerates possible, so as to avoid repeating unnecessary policy measures or influencing market sectors in an undesired way.

Nevertheless, the reasons of divergence from perfect market integration have been investigated by just a limited amount of researchers. The most common variable mentioned is the geographical distance between markets. Engle and Rogers (1996) established that geographical distance, together with the presence of an international border, plays a significant role in explaining the violations of the LOP. Goletti et al. (1995) observed a negative relationship between distance and the co-integration coefficient of rice markets of Bangladesh. Similarly, when investigating the rice markets of Nepal, Sanogo (2008) found a positive relationship between price differentials, road distances and transport costs, as well as a lack of cointegration in relationships with isolated markets. Regarding Peruvian markets, distance and geographical differences were identified as important variables affecting spatial integration (Escobal \& Vásquez, 2008.). Likewise, Rapsomanikis and Karfakis (2004) maintain that distance and transfer costs determine the prices received by farmers. Moreover, Ihle et al. (2011) identified a nonlinear relationship between distance and the transmission of information. Additionally, 
Gonzáles and Helfand (2001) found the distance between Sao Pablo and other Brazilian states to have an effect on the market integration measures.

The variable most commonly cited to explain the link between distance and integration has been transport costs (Paz \& Arinos de Mello, 2003). However, as mentioned above, transfer costs (including transportation, loading and unloading costs, and trader's normal profit) are taken into consideration when the spatial integration measure is used to test the LOP. Consequently, the cost of moving the commodity cannot be the link which clarifies the effect of distance. In view of that, the question of why distance affects integration arises. There are number of theories that look at distance rather than just a measure, as an indication of increases in disparities; for example, culture, economic development, production systems and opportunities (Bergstrand, 1985; Döring \& Schnellenbach, 2006; Inoue, 2008; Peschel, 1981). These disparities could also be a reason for having integration measurements which are different than one, as the LOP predicts. Therefore, analyzing the effects of distance while ignoring these related variables would cause a bias when estimating its influence. This means that in the case where distance has an effect on cointegration, it is imperative to correct for the impact of other variables that might also affect integration and are also likely to be correlated with distance in order to measure its influence correctly. In order to avoid bias, and at the same time improve the knowledge of the determinants of the integration, an investigation which incorporates these variables is needed.

Brazil offers an ideal opportunity to analyze this issue. The land of contrasts (Vinod, 2006) is the fifth biggest country in the world divided into five regions and 26 states. Here the distance between regions creates divergences in terms of natural recourses, economic development, and access to external markets, among others. The clearest example is the inequality in terms of socioeconomic development, where the Southeast Region (SE) is the most developed and shows a per capita income twice of that of the North $(\mathrm{N})$ and three times that of the Northeast (NE), where most of the country's poverty lies (IBGE, 2011).

Moreover, two characteristics of the Brazilian rice market made it suitable for this analysis. First of all its importance: it is consumed and produced in all states and is a main staple food in Brazil, which accounts for $8.5 \%$ of yearly household food expenses (IBGE, 2010). Secondly, the principal characteristics of this market are linked its geographical location, as the production system differs depending on the location, meaning that closer markets are more similar. To this can be added that the most important states in terms of production and consumption are close to each other.

The main objective of this research is to investigate the influence of geographical distance on integration measures while taking the bias caused by the omission of variables which influence integration and are likely to be correlated with distance into consideration. To study this we analyze Brazil's rice market. With this information, the knowledge about the determinants of integration and their importance in the case of Brazil will be built upon. For this intention the cointegration framework is applied. Spatial integration is calculated between each market pair. In order to account for multiple 
changes in the Brazilian economy during the period investigated, the presence of multiple structural breaks in the long run equation is allowed for. The estimation of the relationship between the integration measure and geographical distance is made using OLS regression. Finally, in order to account for the effects of the addition of related variables, the Omitted Variables Bias is used.

Based on the literature review, two main contributions of this work to spatial price transmission analysis deserve to be highlighted. First, the analysis is based on a considerable number of markets (25 states), allowing for the use of OLS regression to analyze the effect of the distance and other related variables on integration and thus giving more robust results. Secondly, the inclusion of a set of variables, apart from distance, has not yet been used to explain integration relationships.

This paper is organized as follows: Section 2 describes the estimation methods and the theoretical background of the work at hand. Section 3 provides an overview of Brazil's rice market and the variables linked to distance and integration. Section 4 gives an overview of the relevant economic and policy changes in Brazil. The data characteristics are presented in Section 5 and the results are given in Section 6. Section 7 concludes with final remarks.

\subsection{Methodology and Theoretical Background}

\section{a. Cointegration-based Measurement of Market Integration}

A basic, and perhaps less ambiguous, concept within market integration analysis is spatial arbitrage, which holds that prices of a good in any two locations will differ by no more than the transfer costs of moving the product from the lower to the highest price market (Baulch, 1997; Fackler \& Goodwin, 2001).

$P^{\text {high }}-P^{\text {lower }} \leq K$

Accordingly, equation (5.1) is known as the arbitrage condition and is the starting point of any model of market integration or spatial price behavior. When the gains of spatial arbitrage are exhausted $\left(P^{\text {high }}-P^{\text {lower }}-K=0\right)$, a more restricted form of equation (5.1) occurs: the Law of One Price (LOP). It holds that when considering two markets (X and $\mathrm{Y}$ ) trading a commodity in period $t$, the markets are integrated if the price in one market equals the contemporaneous price in the other, plus transfer costs. Then, redefining equation (5.1):

$P_{t}^{y}=\beta_{0} K_{t}+\beta_{1} P_{t}^{x}+\mu_{t}$.

Where $\mu$ is the error term and $P_{t}^{i}$ is the price of market $\mathrm{i}(\mathrm{i}=\mathrm{x}, \mathrm{y})$ at period $t$ and $K_{t}$ is the transfer costs. The fulfillment of the strong form of LOP is such that $\beta_{0}=\beta_{1}=1$ and $\mu_{t}=0$ for all $t$ (Baulch, 1997; Fackler \& Goodwin, 2001).

However, the LOP should be seen as a long run equilibrium concept to which common currency prices, after a period of time in which the arbitrage gains are exhausted, will converge. Based on that, the LOP has been analyzed using the cointegration test which, because of its inclusion of the time 
series properties of the prices, has became a very popular method (Ardeni, 1989; Goodwin, 1992; Miljkovic, 1999). The definition of cointegration states that even if many factors may cause changes in the time series, some common long run equilibrium relationship exists which bound the series together, which can be represented by a linear combination similar to equation (5.2) (Hamilton, 1994). It is the same to say that even if in the short run $P_{t}^{y}$ and $P_{t}^{x}$ (non-stationary variables) wander extensively on their own and $\mu_{t} \neq 0$, they are going to be linked by stable long run equilibrium if the error term $\left(\mu_{t}\right)$ is stationary.

Nonetheless, one of the biggest problems within integration analysis is the difficulty of directly observing the transfer costs. It is thus common to approximate the transfer costs as a constant, or in the case of a logarithmic model, as a constant proportion of prices. In that case, it is possible to represent transfer costs as a constant $\beta_{0} \neq 0$ and redefine equation (5.2) as follows (Fackler \& Goodwin, 2001): $P_{t}^{y}=\beta_{0}+\beta_{1} P_{t}^{x}+\mu_{t}$

It is the same as that of equation (3.1) in Chapter 3, where $\beta_{0}$ represents transfer costs and, when the prices are included in logarithmic form, $\beta_{1}$ corresponds to the elasticity of cointegration.

For this investigation Engle and Granger's (1987) two step procedure is applied, which is one of the most commonly used to test for the existence of non-spurious long run equilibriums between each pair of the prices included in the research (Kirchgässner \& Wolters, 2007). This approach requires that one of the prices be designated as exogenous. This means that in equation (5.3) $P_{t}^{x}$ influences $P_{t}^{y}$, or it is the same to say that market $\mathrm{X}$ is the leader in the relationship and market $\mathrm{Y}$ is the follower. In order to establish this, the Granger Causality test (Granger, 1969), including the modification suggested by Dolado and Luetkepohl (1996) is applied. The cases will only be selected if the notion that $P_{t}^{x}$ is causal of $P_{t}^{y}$ is fulfilled, but not if it is not.

After the selection of pairs and the determination of the order of the series, the long run equilibrium is calculated based on equation (5.3). Different tests are used to prove the stationarity of $\mu$. Among them is the ADF test with adjusted critical values; the significant number of lags is calculated by computing the Akaike's information criterion (AIC), Schwarz's Bayesian information criterion (SBIC) and the Fixed criterion. The other unit root tests used are the Phillips-Perron Test, the ERS-Test (Ptest) and the Schmidt-Phillips (SP) test (Pfaff, 2006).

After the application of the above described, it is then known between which pairs of markets cointegration exists, as well as the elasticity that describes the long run relationship. However, a better understanding of spatial integration needs to consider the short run pattern of integration. With this aim, the Error Correction Model (ECM) described in Section 3.3 with equations (3.3.1) and (3.3.2) is applied. 
As was described in Section 3.3, when $\alpha_{y}$ is significant and $\alpha_{x}$ is not any deviation from the long run relationship will cause an adjustment of $P_{t}^{y}$ but not of $P_{t}^{x}$. We can say that equation (3.3.1) corresponds to the short run adjustment of the "follower market", as in each case $P_{t}^{y}$ is the price which adjusts. Finally, since seasonality of the crop cultivation can affect prices, $D_{i}$ is included and corresponds to the seasonal dummy variables, where $i$ ranges from 1 to 12 .

In some cases, the long run equilibrium remains constant over a period of time, and then shifts to a new one. In view of that, it is important to take into consideration that Brazil has experienced a phase of intense economic changes during the period included, which will be explained further in the next section. Hence the omission of this situation could provoke a bias of the results. In order to find evidence of structural breaks among the cointegration relationships, the Empirical Fluctuation Process (RE test), suggested by Kuan and Hornik (1995), is applied to the long run equation. In the cases where there are indications of instability, the procedure suggested by Bai and Perron (1998), modified by the significant values proposed by Kejriwal and Perron (2010), is used in order to identify the number and the period of structural breaks. Thereafter, the long run equation (5.3) is replaced by one of the possibilities suggested by Gregory and Hansen (1996), which considers the idea of cointegration allowing for structural breaks:

$$
\begin{aligned}
& P_{t}^{y}=\beta_{0}^{1}+\beta_{0}^{i} \psi^{i}{ }_{t \tau}+\beta_{1}^{1} P_{t}^{x}+\eta_{t} \\
& P_{t}^{y}=\beta_{0}^{1}+\beta_{0}^{i} \psi^{i}{ }_{t \tau}+\beta_{1}^{1} P_{t}^{x}+\beta_{1}^{i} \psi_{t \tau}^{i} P_{t}^{x}+\eta_{t} .
\end{aligned}
$$

Defined as:

$$
\psi^{i}{ }_{t \tau}=\left\{\begin{array}{lll}
0 & \text { if } & \tau^{i} \leq[n \tau], \\
1 & \text { if } & \tau^{i}>[n \tau]
\end{array}\right.
$$

where the parameter $\tau \in(0,1)$ denotes the timing of the change point, and [] denotes the integer component, i corresponds to the number of breaks, which can be a maximum of 2 . $\beta_{0}^{1}$ corresponds to the intercept before the shift and $\beta_{0}^{i}$ represents the change in the intercept at the time of the shift. $\beta_{1}^{1}$ designates the cointegration slope coefficients before the regime shift, and $\beta_{1}^{i}$ corresponds to the changes in the slope. Therefore, equation (5.4.1) describes a change only in $\beta_{0}$, which has been defined as a representation of the transfer costs, and equation (5.4.2) allows for an alteration of $\beta_{1}$, which is the elasticity of cointegration. Using the minimum AIC, the equation which describes the behavior of $P_{t}^{y}$ more significantly is selected. Once again the new error term, named $\eta_{t}$ in this case, is tested for stationarity using the same indicators mentioned above, and then is used to estimate a new ECM. 


\section{b. Quantifying the Relationship between Market Integration and Distance: Bias and Incidence of the Related Factors}

As explained above, the LOP predicts an elasticity equal to 1 , however, the cointegration literature illustrates that in some cases markets are not perfectly integrated ( $\beta_{1} \neq 1$ ) (Ardeni 1989, Dutoit et.al, 2010; McKenzie \& Pede, 2005; Sanogo, 2008). The geographic distance between markets has been pointed out as a possible explanation (Escobal \& Vásquez, 2008; Goletti et al., 1995; Gonzáles \& Helfand, 2001; Rapsomanikis \& Karfakis, 2004). The finding suggests that markets separated by a long distance will have smaller elasticities, meaning less cointegration than closed markets. The literature explains this by the increase in transport costs in response to an increase in the distance between markets. A negative value of $\varphi_{1}$ can be awaited in the following equation:

$$
\text { Integration Measure }=\varphi_{0}+\varphi_{1} \text { Distance between } \mathrm{X} \text { and } \mathrm{Y}+\epsilon_{1} .
$$

Nevertheless, if the constant coefficient of the long run equation is an adequate approximation of transfer costs, as is proposed by the idea of the application of cointegration to analyze the LOP, an effect of an increase in distance on the elasticity of cointegration is not explained by an increase in transfer costs. The hypothesis proposed in this investigation is that some market factors vary with distance, and these variables are responsible for the significant outcome of $\varphi_{1}$ in equation (5.5). Regarding the second part of the methodology, the presence of a bias in the coefficient $\varphi_{1}$ is examined, explained by the absence of these characteristics in equation (5.5).

The methodology described in the last sub-section is carried out for each pair of Brazilian rice markets. The multivariate analysis is not included as the analyses with numerous states turned out to be computationally unmanageable, particularly due to the low degrees of freedoms resulting from the inclusion of seasonal dummies and break dummies. Up to this point, the results are two measures of spatial integration:

i. Elasticity of cointegration $\left(\beta_{1}^{\bar{i}}\right)$ : As a maximum of two structural breaks is allowed for, it is possible to have at most three elasticities (i can be from 1 to 3) (Figure 5.1). However, the analysis focuses on the elasticities which pertain to before and after the economic changes. Therefore, beta before the period of economic transformations is renamed to Initial Beta and after the last break to Final Beta (Figure 5.1). 
Figure 5. 1

Initial and Final Beta

$\beta_{1}$

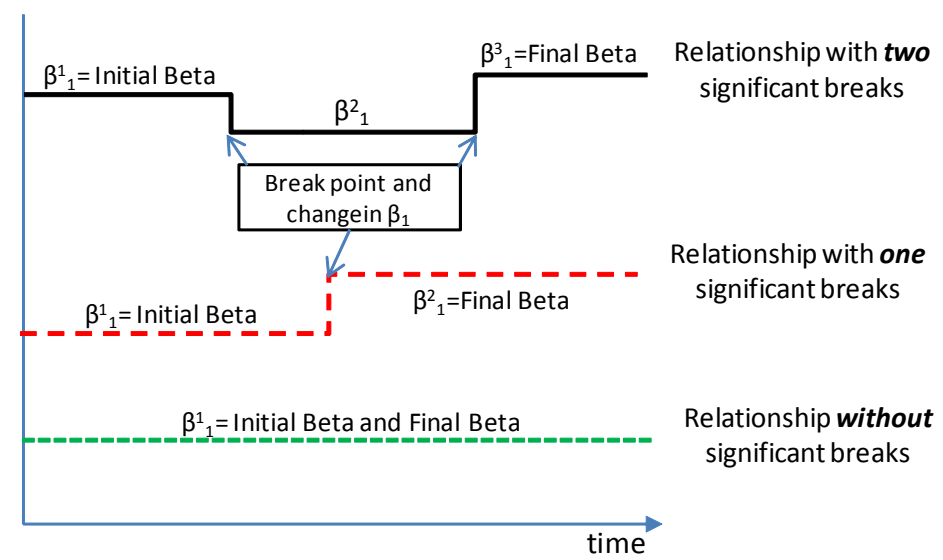

ii. The speed of adjustment ( $\alpha_{y}$ of the follower market from the ECM including ECT allowing for a structural break): Including also the short run dynamics is essential given that the distance could affect both the long run equilibrium and the short run dynamics that govern the maintenance of this equilibrium.

After defining the integration measures, the next step is to analyze which variables determine their variability. As we mentioned above the distance is the most commonly mentioned variable. However, since distance may also increase the discrepancy of other variables between markets, the quality of infrastructure, for instance, also increases. First, distance is regressed as shown in equation (5.5) using a normal OLS model. Thereafter, the Omitted Variable Bias of $\varphi_{1}$, related to the absence of variables which affect integration and are related to distance, is estimated. In order to do this, equation (5.5) is changed to:

Integration Measure $=\vartheta_{0}+\vartheta_{1}$ Distance between $\mathrm{X}$ and $\mathrm{Y}+\vartheta_{2} \mathrm{OV}+\epsilon_{2}$

where OV corresponds to the omitted variable, $\vartheta_{i}$ are parameters to be estimated and the error $\epsilon_{2}$ is assumed to be uncorrelated with the independent variables. In cases where OV changes with distance there will be a significant coefficient $\gamma_{1}$, such that:

$O V=\gamma_{0}+\gamma_{1}$ Distance between $\mathrm{X}$ and $\mathrm{Y}+\propto$.

To obtain the bias, equation (5.6) and (5.7) are used:

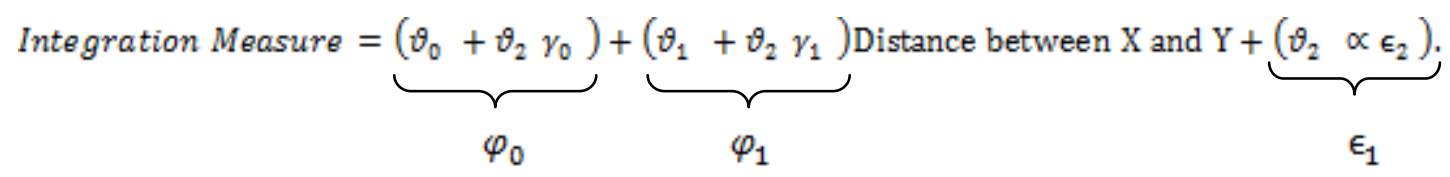

Subsequently, the difference between the value without bias $\vartheta_{1}$ and the value with bias $\varphi_{1}$ depends on the effect of the omitted variable OV (equation (5.6)) and the coefficient of the relationship between distance and OV (equation (5.7)), and then the bias corresponds to $\vartheta_{2} \gamma_{1}$ (Wooldridge, 
2010). However, in order to simplify the interpretation of the results, the bias $\left(\vartheta_{2} \gamma_{1}\right)$ will be presented as percentage of the absolute value of coefficient without bias ( $\left.\vartheta_{1}\right)$. The absolute value is used in order to preserve the sign of the bias.

As is commonly accepted, the term upward bias will be used to refer to an overestimation and downward bias an underestimation of the distance coefficient. Equation (5.6) and (5.7) are estimated using OLS regression.

In some cases the omitted variable OV is a dummy variable, in which case equation (5.7) is replaced by the underlying latent variable model which satisfies the classical linear model assumptions. Let $\mathrm{OV}^{*}$ be an unobserved, or latent variable, determined by:

$\mathrm{OV}^{*}=\gamma_{0}^{*}+\gamma_{1}^{*}$ Distance between $\mathrm{X}$ and $\mathrm{Y}+\propto^{*}, \quad \mathrm{OV}=1\left[\mathrm{OV}^{*}>0\right]$

The model assumes that $\propto^{*}$ is independent from distance. Thus, the approximation of the bias described in equation (5.8) is $\vartheta_{2} \gamma_{1}^{*}$.

All of the econometric analyses were carried out using the free access program R 2.12.1.

\subsection{Brazil's Rice Market}

In Brazil markets are separated not only by physical distance but also by other variables such as differences in developmental status, opportunities and even culture. For instance, productivity and industrialization is highest in the SE and lowest in the NE (IBGE, 2010a). Simultaneously, production in the SE and the South represents 74\% of national GDP (IBGE, 2011). In addition, the Human Development Index (HDI) splits the country in two: the higher developed states in the South, Southeast (SE) and Middle West (MW) and the less developed in the North and Northeast (NE) (UNDP, 2011). These marked differences provide a unique opportunity to analyze not only the effect of distance on integration, but also the possible bias caused by the omission of other distance-related variables.

Likewise, Brazil's rice market is also ideal for the analysis. Rice is a staple product; in Latin America Brazil is the largest producer and $10^{\text {th }}$ in per-capita consumption (371 Kcal/capita/day) (FAO, 2010). It is also net importer, although the bigger proportion of consumption is provided by national production (MAPA, 2010). However, the most important feature is that the closer rice markets have more common characteristics than distant markets, such as the production system used and the quantities of production and consumption. A group of four related variables have been selected. Although the selection does not cover the whole of possibilities, the data available, their importance in the case of Brazil and their feasible effect on integration make them the most adequate ones.

\section{a. Central Markets: Highest Consuming and Producing States}

Within integration analysis, the role of the central markets has been considered for a long time. For instance, Ravallion (1986) based his analysis of spatial market structure on a model which included a 
central market which dominates local price formation. The reason for this is that a higher trade amount is expected from a centralized market than from smaller markets.

In this sense, although rice is consumed and produced in all of Brazil, there are markets which can be highlighted. In the first place, Rio Grande do Sul is the largest producing state accounting for around $57 \%$ of national production in 2006 (IBGE, 2010a). In this state the main characteristics of production are the large size of farms (around $200 \mathrm{ha}$ ) and the high levels of technology (FAO, 2010a). Additionally, Santa Catarina, which is also located in the Southern part, is a main producer as well (9\% in 2006). Although Maranhão is also another core production area (12\%), it cannot be considered a central producer, since production is destined for state consumption only and even in some periods it has been a net importer (IBGE, 2010a). The share of the total production of each of the remaining states is lower than $3.5 \%$.

Regarding consumption, São Paulo, which is located in the SE, is Brazil's largest consumer and has an enormous influence on price determination (dos Santos et al., 2005). Gonzáles and Helfand (2001), through the use of multivariate system, confirm that rice is traded extensively within the country and underscore the centrality of the SE, specifically São Paulo and Minas Geradis, in the adjustment process and the long run equilibrium. Another center of consumption is the NE region, where rice represents $17 \%$ of daily per-capita calorie consumption (IBGE, 2010a).

Even if $16 \%$ of the total production is produced in the NE, this region imports around $75 \%$ of its consumption (CONAB, 2011). This is in part related to the fact that most demand in the NE is from the states of Maranhão and Piauí which have the highest amount of per-capita rice consumption. The $\mathrm{NE}$ is highly dependent on imports from the Southern region, which does not depend on the demand from the NE since its principal market is the SE. This becomes clear when the quantity of consumption is compared, apart from the self-sufficient state of Maranhão only, just São Paulo consumes more rice than all of the NE. Subsequently, the central markets in Brazil are the South as a producer and the SE as a consumer, and the relationships between them and the Brazilian markets are expected to be the strongest.

Based on the information above, we can start establishing the research hypotheses. First of all, there are a higher number of states located in the North and NE (Annex 5.1) and there is a longer distance between them and the principal markets. Therefore, it is more probable to have a relationship in which one of the markets is a central market when the distance is longer. Consequently, a positive coefficient linking the distance and the presence of a central market is expected. Secondly, since it is expected that a stronger integration in those relationships which include a central market exist, analyzing the distance while excluding the presence of a central market will cause an upward bias of the coefficient.

\section{b. Quality of Rice and Production Systems}

The next variable refers to differences in quality of rice which is essential when defining the prices and determining the level of integration between markets. The point is that the demand of each quality 
grade is not always the same. Cramer et al. (1993) found that changes in rice prices as a response to market liberalization was not the same for each rice quality, which can be explained by the influence of the Japanese market and its preference for a specific variety of rice. Moreover, Ghoshray (2008) detects an effect of quality on price integration, pointing out that the low quality market is more competitive than the high quality one.

In Brazil, rice quality practically splits the market in two: high quality production in the South, in some parts of the SE and MW and lower quality rice from the remaining markets (Figure 5.2). These differences are mainly a consequence of production systems (Crusciol, 2008). These can be divided into aerobic/upland rice or irrigated/lowland rice. The latter is characterized by higher, more stable yields and is the only one exported outside of Brazil, whereas upland rice is characterized by less quality and productivity (Wander et al., 2008). YOU (2008) explains this phenomenon, firstly, as a consequence of a bias towards irrigated rice from international and domestic efforts in R\&D and, secondly, of changing rainfall patterns which affects upland production more. In the South almost all rice is irrigated while in the rest of the country upland rice prevails. However, the states of Mato Grosso do Sul, Distrito Federal, Tocantis, São Paulo, Río de Janeiro and Minas Gerais cultivate a fraction of production under the irrigated system (Figure 5.2). New technologies and seed varieties oriented to upland production have been developed in Mato Grosso, thus increasing productivity (de Castro et al., 1999; Embrapa, 2011).

Figure 5. 2

System of Production in Brazil

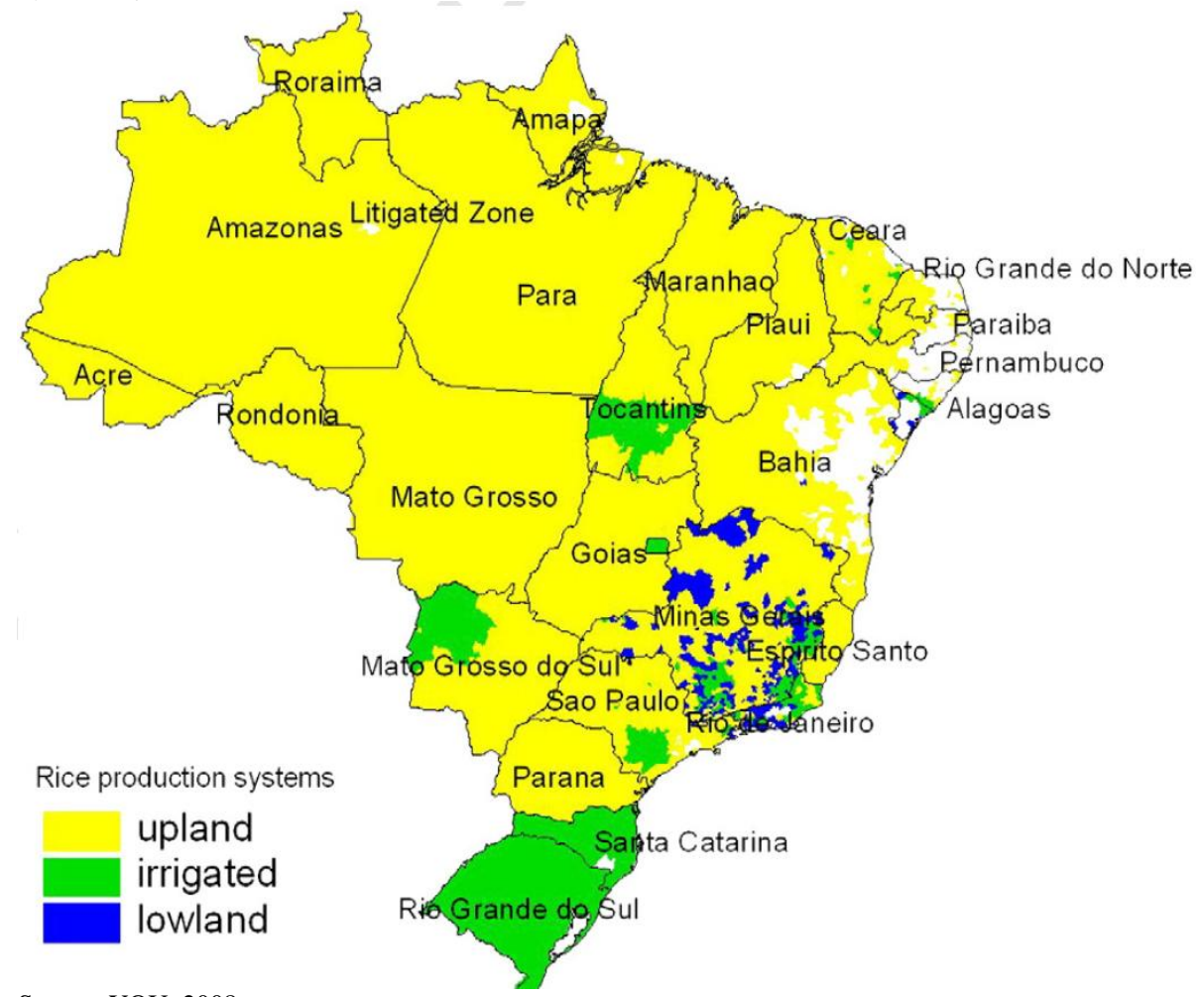

Source: YOU, 2008.

Regarding weather conditions, da Silva and Delgado (2001) state that under conditions of water stress upland rice cultivation shows a reduction in the number of filled grains, grain weight, and total yields 
of dry matter, as well as an increase in the percentage of empty grains. In this sense, the NE is clearly at a disadvantage since it is the driest region with recurrent droughts and high evaporation (INMET, 2011).

Moreover, in Brazil, rice demand used to be centered upon thick rice, typically cultivated using the upland system. However, preferences have changed, with both industry and consumers preferring long, thin rice of the irrigated system (de Castro et al., 1999). As a consequence, rice produced in the South is more expensive than that produced within other markets.

A stronger cointegration between the markets with the same system of production is expected. Inasmuch as these markets are geographically concentrated, it will likely be more probable to find the same system of production in a relationship between two close markets. Consequently, the bias of the distance coefficient associated with the exclusion of the quality of rice will be downward.

\section{c. Gross Domestic Product GDP and GDP per capita}

In order to introduce the next variable, it is first necessary to mention the theory proposed by Tinbergen in 1962 known as the 'gravity model' which has had a lot of successful for explaining trade amounts. The model was developed to explicate the size of trade between two countries using GDP of the exporting market to explain potential supply and the GDP of the importing market to take the potential demand into consideration (Frankel et.al, 1995; Paz \& Arinos de Mello, 2003). Even if the gravity model is based on trade flow it could be expected that, based on the same argument, the size of the market is also a variable which has an effect on integration.

Former researchers, which have used the gravity model approach, have associated the GDP of Brazil with its trading patterns. Jales and Barrantes (2009) and de Sá Porto (2002) found that GDP of Brazil's states is a significant variable which explains the amount of trade, just as much within the country as with international markets.

GDP and GDP per capita vary systematically from north to south (Figure 5.3). The Northern states are the poorest and the South and the SE have the highest GDP, and thus the biggest potential supply and demand. 
Figure 5. 3

Brazilian States by GDP and GDP Per-Capita $2008(R \$)^{*}$

A. GDP

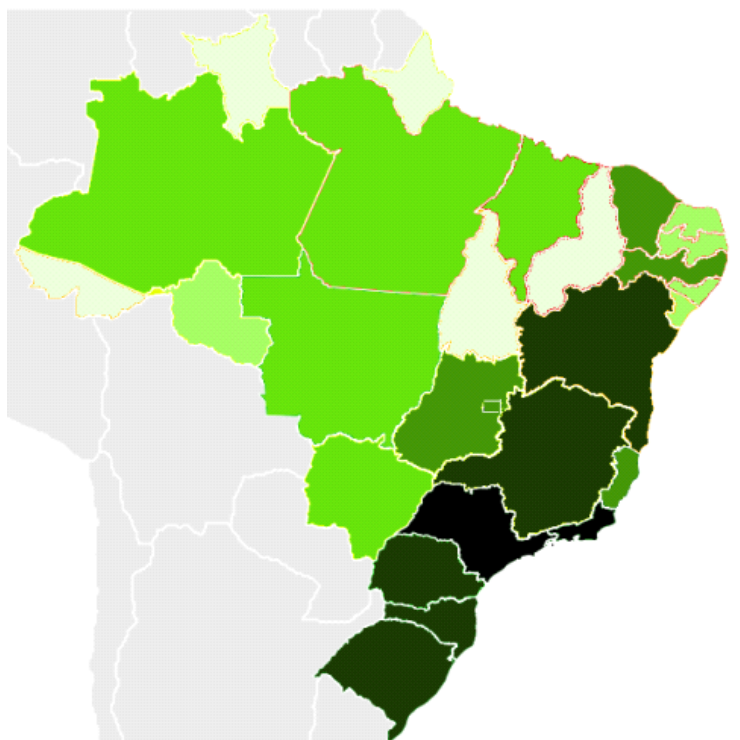

B. GDP per capita

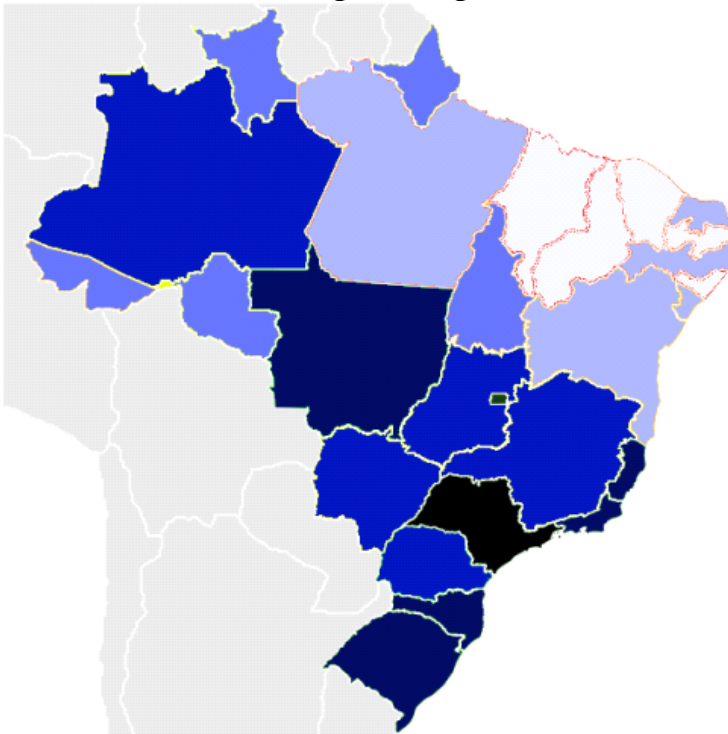

* According to GDP/GDP per-capita, the 27 states are divided into five groups. The group highlighted with the lightest color corresponds to the states with the lowest values and the group with the darkest color with the highest values.

Source: Data IBGE, 2011.

Nevertheless, in view of the huge differences in the areas, such as resources and population spread, the GDP displays the market size dissimilarities; however, it would be going too far to say something about the purchasing capacity and the standard living of Brazilians based on that. The best example is Bahia which occupies the 7 th position of the 27 states in terms of GDP, but has a $43.5 \%$ incidence of poverty (IBGE, 2010). To deal with this situation, in the basic gravity model applications it is usual to find per-capita GDP as an explanatory variable. The idea is that this variable considers the purchasing power of both partners, and that an increment in GDP per-capita has a positive impact on demand, thus increasing the volume of bilateral trade. As is expected, the representation of Brazil changes when GDP per-capita is focused on (Figure 5.3.B). A worse position of the NE states can be seen; however, the geographical concentration is still clear with the highest values in the SE and Southern regions.

Another point to consider was brought up by Kyvik and Hildegum (2004): infrastructure is also highly correlated with the per-capita GDP and finding a significant positive trade coefficient maybe reflects the quality of it. This belief is based on the fact that different levels of per-capita GDP could discourage trade because they reflect discrepancies in infrastructure or dissimilarities in transport services as well. For example, markets which are used to transporting their products using large trucks cannot utilize the same kind of vehicles to export to regions which do not have adequate road quality. The same can be said for telecommunication facilities such as internet and telephone.

The awaited results are that two "large" states, in terms of GDP or GDP per-capita, will have a stronger integration and two "small" states will present a weak relationship since evolving markets have a low supply, demand or purchasing power potential. Moreover, two markets with the same size will be separated by a small distance: hence, a downward bias is expected in the first case and an upward in the second. Finally, the case of different levels of GDP or GDP per-capita, meaning the 
relationship between a "large" and a "small" market, is expected to be weaker due to the effect of the differences in transportation services. In this latter case, the geographical separation is expected to be longer and the bias downward.

\section{d. Access to International Markets: Port Export Points}

International markets play a role in the behavior of prices in Brazil. This is because for the last three decades Brazil has been a net importer of rice; for instance in 1997-2007, imports represented around 9.4\% of total annual consumption (MAPA). Moreover, $98 \%$ of the imports of rice and its derived products came from Argentina, Uruguay or Paraguay (IBGE, 2010), where rice is produced more efficiently and with lower costs than Brazil, for which market prices are lower in comparison to nationally produced rice (da Silva \& Dalla, 2009).

In terms of access to these three external markets, once again, the Southern states have an advantage because of the highest quantity of border check points for the transportation of products. $43 \%$ of the Brazil's border-loading points are located in Rio Grande do Sul (ANTT, 2008), the principal importer of rice (53\% of the total imports according to MDIC (2011)), which border Argentina and Uruguay.

However, even if the net importing states of the SE and NE do not share borders with the main international suppliers, they also have a steady amount of rice from Argentina and Uruguay which enters mainly by maritime routes. In Figure 5.4, the increase in the amount of imports of maritime routes can be observed, which in some periods has been higher than $20 \%$ of the total. Therefore, proximity to a main port also has an impact on having access to rice with lower prices from the external markets. Related to this, Francois and Manchin (2007) investigate the effect of having access to a coast on trade using a panel of bilateral trade flow information of countries from around the world. They find that the landlocked countries consistently export a small amount; moreover, their probability of exports overall is smaller. Along the same line, Limão and Venables (2001) find that overland distance is around 7 times more expensive than sea distance, and being landlocked increases transport costs by approximately $50 \%$. 
Figure 5. 4

Proportion of Brazil's Total Rice Import which Enter by Maritime Route* Quarter Data 199/1 - 2008/4. US\$ FOB

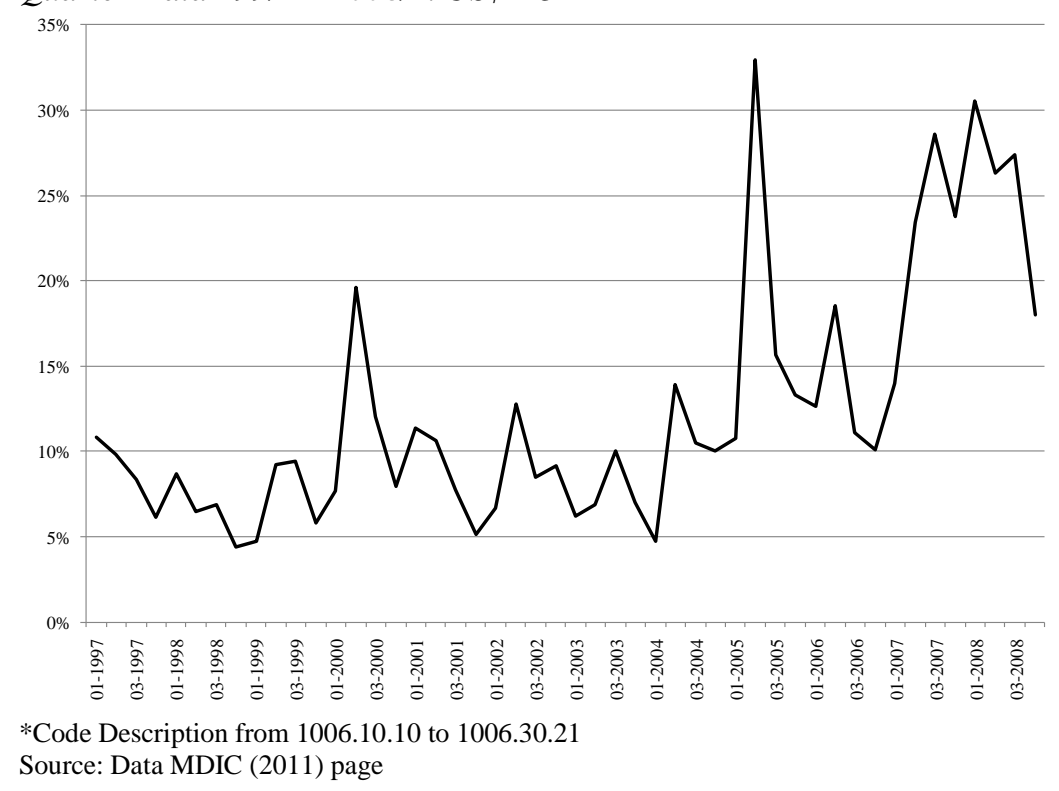

Nevertheless, having a port near a market does not have the same effect on all coastal economies; it is necessary to consider the incidence of other variables. First, the efficiency of the port: Kyvik and Piermartini (2004) found empirical evidence which indicates that port efficiency has a higher impact on bilateral trade flows than the quality of roads, airports and telecommunications. In this sense, Brazil experienced a revolution during the 90's. Prior to that, the administration of the ports was dealt with by one organization only, Portobrás, which had an obsolete and bureaucratic structure. The disappearance of this organization in 1990, together with a lack of an alternative functional organization, leads to a crisis. However, a fixable solution to the crisis redesigned and improved the entire port sector starting with the creation of Law 8.630/1993. This law lead to an expansion in private sector participation, a growth in investments, an impressive reduction in costs (from 500 USD to 150 USD on average), a review and optimization of rates, etc., thus generating an increase in competition and efficiency (Cárdenas, 2006). As a consequence, the quantity of bulk cargo mobilized, a category which also includes rice, increased significantly. Between 1988 and 1993, the growth rate was just 0.4\%, while it increased to 4.2\% during 1994-1999 and to 8.5\% during 2000-2005 (Cárdenas, 2006; IPEA, 2010). All of these improvements are evident in Pernambuco (NE) and Rio de Janeiro (SE), where the majority of maritime rice imports enter (MDIC, 2011) which is in part explained by their ports' conditions. The ports of Recife and Suape are located in Pernambuco, two of the most important ports of the NE; the latter accounting for the highest amount of unloaded tons in the NE (ANTAQ, 2009). Rio de Janeiro counts with the ports of Rio de Janeiro and Itaguaí. The latter port is 36th in terms of total cargo volume in the world and is one of the most modern ports in Latin America (AAPA, 2009). However, the amazing growth in trade has triggered a constant necessity of faster improvements which has not been possible to achieve. Subsequently, the performance of ports is far from being efficient. This is confirmed by research conducted by the Institute of Applied Economic Research of Brazil (IPEA, 2010) which pointed out the gap in dredging, construction and expansion of 
Brazil's ports. In addition, Cristovão dos Santos and Amaral (2007), based on the methodology proposed by Blonigen and Wilson (2006), found that the relative efficiency rate of ports which handle bulk cargo is lower than $40 \%$.

The second variable to take into consideration is the quality of roads since problems in physical transportation makes access to ports difficult and more expensive. According to Francois and Manchin (2007), this is a central aspect which affects the possibility of trade in developing countries more than in developed ones. Regarding Brazil, IPEA (2010), using information from the Ministry of Transportation, the Confederação Nacional do Transporte, Regional Governments and the Programa de Aceleração do Crescimento (Growth Acceleration Program), recognized the necessity of around 11 billion USD for investments to improve and extend land access to ports, as financial resources are one of the most significant bottlenecks in their operations.

The expectations of this sub-Section can be split into two parts. On the one hand, the net demanding markets close to a main port, in view of their extra abilities for importing at better prices, will be less dependent on the national suppliers of the South and the elasticity of cointegration with them will be smaller. Most of the demanding markets are located in the NE, and therefore long distance relationships will be less integrated. However, the effect could be hindered by the efficiency of the ports and the quality of roads. On the other hand, in the case of the net supply markets of the Southern coast; the closeness to the external markets presents more competition, but this does not mean that integration with the internal markets will be significantly affected.

However, the Brazilian coast is long and internal markets in Brazil also use maritime routes to trade from South to North. Subsequently, proximity to a port improves not only the trade with international markets, but also internal commerce, due to a reduction in transfer costs.

\subsection{Economic and Political Reforms: 1990 - 2006}

In order to fight against the threat of hyperinflation, stabilization plans were implemented during the 90 's, reducing the influence of the government, thus increasing private participation, while changing the distribution of resources and altering the share of market covert for each state (Guanziroli, 1999). This development was joined by a process of trade liberalization.

The sudden and deep effects of some of these measures on the agricultural sector changed the relationship between markets. First off, the earliest two stabilization plans, one in 1990 referred to as the "Plano Collor I" and the second in 1991 known as "Plano Collor II", did not permanently reduce inflation but generated huge instability in the agricultural sector. At the same time, the Minimum Price Policy, created to support commercialization while guaranteeing an income for producers and a steady supply for consumers, was interrupted (1990-1991) and reactivated throughout the period of 1992 to 1995. In 1994, the so-called "Plano Real" began, its principal objective being to control of inflation, an aim which had an enormous success. However, the plan had unexpected consequences, and in the second part of 1994 and most of 1995 a severe financial crisis affected the agricultural sector as the 
prices for both land and agricultural commodities fell abruptly (Helfand \& Castro, 2001). In the middle of the crisis an agricultural reform began, with changes in the price support policies and in the interest rate of rural credits (de Oliviera et al., 2008). Later, in January of 1999, another main change occurred as the currency was allowed to float freely and depreciated by $50 \%$, thus affecting imports in a negative way. This disincentive to import persisted until the crop failure of 2002-2003 in Rio Grande do Sul which caused a great increase in the national rice price levels (Marion \& Eich, 2008).

These adjustments affected both consumers and producers and at the same time changed the relationships between markets. First, the opportunity costs of buying products from an international market were modified through the variation of the exchange rates. Moreover, a crop failure, like the one in 2002, forces a market to look for new export partners and thus establish new alliances which facilitate future commerce. In addition, adjustments of market conditions, such as price support and credit options, could favor some producers and damage others.

Even if it is possible to identify the most important events, the characteristics associated with each market sector in Brazil point to the fact that variances in cointegration relationships will not be the same in amount and time. For instance, during 1990-2006, price support policy initiatives experienced improvements which lead to, as an effect, the producers of the most developed markets, such as Rio Grande do Sul and Santa Catarina, applying the more sophisticated instruments than the less developed markets, to assure themselves less volatile rice prices and a more stable income (de Oliviera et al., 2008). In addition, the price policy protects more those producers in states that in terms of production have a higher participation in the market. Furthermore, during the 90's, the state of Rio Grande do Sul was strongly supported by the government due to the intense and rapid increase of Argentina's rice exports to Brazil. Moreover, in those markets where rice is not a staple product, the policy support was minimal or not too significant; for example, the minimum price policy in the North started much later on, in Acre and Rondõnia at the end of 2004, and in Amazonas, Amapá, Pará and Roraima after 2006 (CONAB, 2011b).

In view that the agricultural sector experienced strong and quick policy changes, it is expected that the price transmission relationships will present structural breaks and that the break points will not be the same for all pairs.

\subsection{Data Base}

Brazilian producer prices were provided by the Economic Commission for Latin America and the Caribbean of Chile (ECLAC) and are from the ECLAC's office in Brazil. The data corresponds to the producer prices of 25 Brazilian states (Annex 5.1, Figure 5.6). The time span of the monthly data starts in February 1990 and ends in January 2006 for the majority of the series (Annex 5.2, Table 5.9 and Figures 5.7 to 5.10). The market exchange rate average was obtained from the International Financial Statistic (IFS) and was used to convert the prices into US dollars per kilo. Details of the related variables are given in Table 5.1. 
Table 5. 1

Description of the Indicators Used to Evaluate the Related Variables

\begin{tabular}{|c|c|c|c|c|}
\hline Variables & Name & $\begin{array}{l}\text { Type of } \\
\text { Variable }\end{array}$ & Description & Source \\
\hline \multicolumn{5}{|c|}{ Integration Measures } \\
\hline Initial Beta & $\beta_{1}$ Initial & Continuous & $\begin{array}{l}\text { Elasticity of cointegration BEFORE the period } \\
\text { of economic transformations }\end{array}$ & Author's Estimation. \\
\hline Final Beta & $\beta_{1}$ Final & Continuous & $\begin{array}{l}\text { Elasticity of cointegration AFTER the period } \\
\text { of economic transformations }\end{array}$ & Author's Estimation. \\
\hline Speed of Adjustment & $\alpha_{\mathrm{y}}$ & Continuous & $\begin{array}{l}\text { Speed of adjustment to the long run } \\
\text { equilibrium }\end{array}$ & Author's Estimation. \\
\hline \multicolumn{5}{|c|}{ Related Factors } \\
\hline Geographic Distance & distance & Continuous & $\begin{array}{l}\text { Travel time in hours between the states' } \\
\text { Capitals }\end{array}$ & Google maps \\
\hline \multicolumn{5}{|c|}{ Omitted Variable $(\mathrm{OV})$} \\
\hline $\begin{array}{l}\text { a. Central Markets: } \\
\text { Highest Consuming } \\
\text { and Producing States }\end{array}$ & Central Market & $\begin{array}{l}1 \\
0\end{array}$ & $\begin{array}{l}\text { Relationships included one of the followers } \\
\text { central markets: Santa Catarina, Rio Grande do } \\
\text { Sul and/or São Paulo. } \\
\text { Without central market }\end{array}$ & $\begin{array}{l}\text { Central Consumer: Pesquis a de Orçamentos } \\
\text { Familiares 2002-2003 (IBGE, 2010). } \\
\text { Central Producers: Censo Agropecuário } \\
\text { 2006 (IBGE, 2010a). }\end{array}$ \\
\hline $\begin{array}{l}\text { b. Similar System of } \\
\text { Production }\end{array}$ & $\begin{array}{l}\text { System of } \\
\text { production }\end{array}$ & $\begin{array}{l}1 \\
0\end{array}$ & $\begin{array}{l}\text { Equal system of production. } \\
\text { Different system of production. }\end{array}$ & System of Production (YOU, 2008) \\
\hline \multirow{3}{*}{$\begin{array}{l}\text { c. Market Size } \\
\text { GDP }(1000 \mathrm{R} \$) \text { and } \\
\text { GDP Per Capita (R\$) }\end{array}$} & Large markets & $\begin{array}{l}1 \\
0\end{array}$ & $\begin{array}{l}\text { Relationship between two markets whose GDP } \\
\text { or GDP per capita is higher than the average. } \\
\text { Other }\end{array}$ & \multirow{3}{*}{$\begin{array}{l}\text { GDP and GDP per Capita: } \\
\text { Producto Interno Bruto dos Municípios } \\
\text { 2004-2008. } \\
\text { (IBGE, 2011) }\end{array}$} \\
\hline & Small and Large & $\begin{array}{l}1 \\
0\end{array}$ & $\begin{array}{l}\text { Relationship between one market whose GDP } \\
\text { or GDP per capita is higher and another whose } \\
\text { is lower than the average. } \\
\text { Other }\end{array}$ & \\
\hline & Small markets & $\begin{array}{l}1 \\
0\end{array}$ & $\begin{array}{l}\text { Relationship between two markets whose GDP } \\
\text { or GDP per capita is smaller than the average. } \\
\text { Other }\end{array}$ & \\
\hline \multirow{2}{*}{$\begin{array}{l}\text { d. Close to an } \\
\text { important port in } \\
\text { terms of unloading } \\
\text { Bulk Cargo }\end{array}$} & $\mathrm{X}$ & $\begin{array}{l}1 \\
0\end{array}$ & $\begin{array}{l}\text { The leader has a main port in the state. } \\
\text { The leader has not a main port in the state. }\end{array}$ & \multirow{2}{*}{$\begin{array}{l}\text { Main port in terms of Bulk Cargo: } \\
\text { Anuário Es tatístico Portuário }-2006 \\
\text { (ANTQ, 2006). }\end{array}$} \\
\hline & $\mathrm{Y}$ & $\begin{array}{l}1 \\
0\end{array}$ & $\begin{array}{l}\text { The follower has a main port in the state. } \\
\text { The follower has not a main port in the state. }\end{array}$ & \\
\hline Road Quality & $\begin{array}{l}\text { Road extension } \\
\text { per } \mathrm{km}^{2}\end{array}$ & Continuous & $\begin{array}{l}\text { Extension in km of state and state transitory } \\
\text { paved road per } 1000 \text { square } \mathrm{km} \text {. }\end{array}$ & $\begin{array}{l}\text { Anuário Estatístico dos Transportes } \\
\text { Terrestes-AETT/2008 (ANTT, 2008). }\end{array}$ \\
\hline
\end{tabular}

The type of rice considered is paddy rice, that is, rice that has been cut from the plant only, with the husk, i.e, without any transformation. The variables are used in their logarithmic form. Missing values represent $2 \%$ of the data base. They were filled in using an imputation algorithm proposed by King et al. (2001) and the corresponding R-package AMELIA II, developed by Honaker et al. (2009). 1000 imputations for each missing value were performed and their most likely values were estimated using Parzen's (1962) nonparametric mode estimator.

\subsection{Analyzing and Using Assessment Findings}

Before beginning the cointegration analysis, it is necessary to identify the integration order of the series. The ADF test is estimated three times, each with a different assumption about the variable. The first assumes the presence of an intercept only, the second a trend only, and finally, both. In light of the critiques of the ADF Test, the following tests are also included: the Phillips-Perron Test, ERS-Test or P-test, and Structural Break (Zivot-Andrews Test). For some variables, the resulting integration order is not the same for all tests. Therefore, an integration order is selected that corresponds to at least 
three of the applied tests. There are 25 prices, 24 are non-stationary and the first difference for each variable is $\mathrm{I}(0)$ (Table 5.10).

Recalling what has been said in Section 5.2 in sub-section a, the Engle and Granger procedure requires that one of the prices be designated as exogenous and the other as endogenous. This means that in each relationship one price $\left(P_{t}^{x}\right)$ is affected by the other $\left(P_{t}^{y}\right)$ and not the opposite. The market relating to the first price is called the follower market, and the market relating to the second price the leading market. The Granger Causality test is undertaken to find which market corresponds to the leading and which to the follower market in each relationship. The states of São Paulo and Rio Grande do Sul, which have been identified as central markets, together with Distrito Federal which is the Capital of Brazil, are leaders in all the relationships. In addition, Minas Gerais, Santa Catarina and Espíritu Santo in the South and SE, jointly with Mato Grosso and Goias in the MW are leading markets in the majority of the relationships as well. On the other hand, Amazonas and Rio Grande do Norte are always following markets, and the markets which are not exclusively but often followers are located in the North and NE.

After the Granger Causality test and the stability analysis, 152 pairs are found to be cointegrated. Just two of them do not present significant structural breaks: Tocantis vs. Distrito Federal and Tocantis vs. Santa Catarina. It is worthy to note that the available series of Tocantis's prices starts on January of 1998 which is after the application of the Real Plan and its main consequences. Amazonas is the state with the highest number of cointegration relationships, followed by Acre, while Rio Grande do Norte is the least connected. However, the level of connection among markets is similar since 18 of the 25 markets have 10 to 14 significant relationships. The elasticities of cointegration and the speed of adjustment are distributed over a wide range of values. First, the $\beta_{\text {initial }}$ is distributed between 0.01 (Roraima vs. Distrito Federal) and 1.42 (Santa Catarina vs. Distrito Federal). The $\beta_{\text {final }}$ has a maximum of 1.6 (Mato Grosso do Sul vs. São Paulo) and a minimum of 0.016 (Pará vs. Minas Gerais). Nevertheless, there is a concentration of the elasticity around 0.8 , both before and after the structural break, as shown in Figure 5.5. Furthermore, the number of relationships with values higher than 0.5 increases after the economical and political adjustments, thus, in general, the integration becomes stronger. The speed of adjustment $\left(\alpha_{\mathrm{y}}\right)$ is dispersed from -0.09 (Maranhão vs. Bahia) to -0.72 (Tocantins vs. Acre), with a stronger concentration among lower values, the standard deviation is 0.13 and the average -0.33 . 
Figure 5. 5

Frequency of Beta
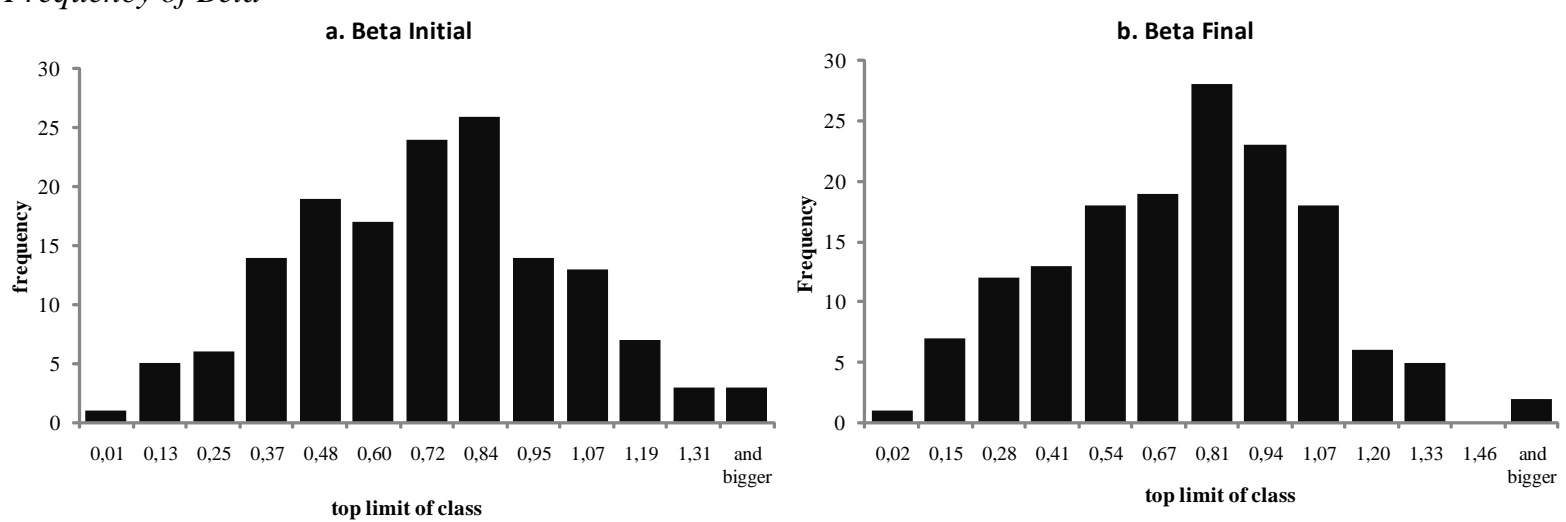

Source: Author's Elaboration.

Table 5.2 displays the distribution of the periods in which the relationships with evidence of significant cointegration present significant structural breaks. The first break occurs in the majority of the cases between 1991 and 1994, which correspond to the applications of the Collor I, Collor II and the Real Plan (ninth column Table 5.2). The second break has a higher distribution (last row Table 5.2 ); however, the period with the higher quantity of observations corresponds to the crop failure in Rio Grande do Sul and the reevaluation of the Real (2003-2004). Moreover, the second break also has an important concentration between 1995 and 1998 which is the period associated with the crisis resulting from the Real Plan. Most of these relationships (highlighted in Table 5.2) show the first break at the start of Real Plan (1993-1994) and involve the states of Acre, Amazonas and Pará, which are all located in the Northern region. These states are similar in the sense that at the time they were not protected by the minimum price policy and that rice does not play a central role in their economies which could explain why the stabilization plans and the crisis affected them quickly.

Table 5. 2

Period of Significant Structural Breaks (Number of Relationships)

\begin{tabular}{|c|c|c|c|c|c|c|c|c|c|}
\hline \multirow[b]{2}{*}{ First Break } & \multicolumn{8}{|c|}{ Relationships with Two Significant Breaks } & \multirow{2}{*}{$\begin{array}{l}\text { Relationships } \\
\text { with One } \\
\text { Significant Break }\end{array}$} \\
\hline & 1991-1992 & 1993-1994 & 1995-1996 & $1997-1998$ & $1999-2000$ & $2001-2002$ & 2003-2004 & & \\
\hline $1991-1992$ & 5 & 9 & 6 & 6 & 4 & 3 & 5 & 38 & 1 \\
\hline 1993-1994 & & & 23 & 13 & 5 & 3 & 8 & 52 & 2 \\
\hline 1995-1996 & & & & 9 & 2 & 3 & 2 & 16 & 1 \\
\hline $1997-1998$ & & & & & 4 & & 4 & 8 & 0 \\
\hline $1999-2000$ & & & & & & 2 & 12 & 14 & 1 \\
\hline $2001-2002$ & & & & & & & 11 & 11 & 4 \\
\hline 2003-2004 & & & & & & & & $\mathbf{0}$ & 2 \\
\hline Total & 5 & 9 & 29 & 28 & 15 & 11 & 42 & 139 & 11 \\
\hline
\end{tabular}

Continuing with the analysis, the results of equation (5.5) are presented in Table 5.3. First, it is possible to observe a negative and significant relationship between the elasticity of cointegration and distance. However, this relationship is weak; a change of 10 hours in distance decreases the initial elasticity by around 0.07 . 
Moreover, there is not a significant effect on the speed of adjustment. One possible explanation could be an asymmetric behavior of the adjustment, which means a different speed when the deviation from the equilibrium is negative than when positive (see Section 4.2 equations (4.1.1) and (4.1.2)). This is tested using the asymmetric price transmission analysis proposed by von Cramon-Taubadel (1989), whereby only 6 of the 152 pairs show evidence of asymmetry. Another feasible explanation is that even if the ECM takes the effect of weather seasons into consideration (by including the dummy variables), an essential variable in terms of rice production, the measure of the distance in hours does not. Distance could change considerably between the dry and rainy seasons, especially in the North, MW and NE where the states with the least extension of paved road per $\mathrm{km}^{2}$ are located. However, at the moment, another approximation of distance which considers it does not exist.

Table 5. 3

Effect of Distance on Cointegration

\begin{tabular}{lccl}
\hline & $\beta_{1}$ Initial & $\beta_{1}$ Final & $\alpha_{\mathrm{y}}$ \\
\hline Constant & $0.870 * * *$ & $0.818^{* * *}$ & $-0.317 * * *$ \\
Distance & $-0.007^{* * *}$ & $-0.005 * * *$ & 0.000 \\
\hline F statistic & $22.4 * * *$ & $8.33 * * *$ & 0.531 \\
Heterocedasticity & Not & Yes & Yes \\
Normality & Yes & Yes & Not \\
Autocorrelation & Yes & Yes & Not \\
$\begin{array}{l}\text { Level of significance: } *=0.1, * *=0.05 \text { and } \\
\text { Source: Author's Elaboration. }\end{array}$ & & &
\end{tabular}

Starting in Table 5.4 the analysis of the related variables and their biases are shown. Before beginning, some clarifications are necessary. First, given that no significant relationships for the speed of adjustment were found, there are no estimations of biases related to this integration measure. Secondly, a significant bias corresponds to those cases which have two characteristics: i) a significant relationship between distance and the related variable (significant $\gamma_{1}$ in equation (5.7)), and ii) a significant coefficient of the related variable explaining the elasticity of cointegration (significant $\vartheta_{2}$ in equation (5.6)). In the case of the central market (Table 5.4) there is not a significant bias, however the variable is important for explaining the behavior of all three integrated measurements. Having a central market in the relationship implies a faster adjustment, which can be explained by a more efficient intermediate structure and better access to information. Regarding the elasticity, there is an opposite effect before and after the economic adjustments. This could be associated with changes in the magnitude of the main markets. First, from the supply side, the main role of Rio Grande do Sul has been increasing enormously, from a participation of around $41 \%$ of national production in 1991 to 63\% in 2008 (CONAB, 2011a). Secondly, from the demand side, even if we do not have historical consumption data, the fact that in São Paulo both the amount of production and the cultivated area have been decreasing suggest a greater dependence on imports. For instance, during 1991-2006 production decreased by $75 \%$ and the area by $86 \%$. Moreover, the population increased, by $131 \%$ during the period of 1990 to 2000 (CONAB, 2011a; IBGE, 2011a). 


\section{Table 5.4}

Effect of Having a Central Market on the Relationship

\begin{tabular}{cccc}
\hline $\begin{array}{c}\text { Equation (5.7) } \\
\gamma_{0}\end{array}$ & $0.210 * * *$ & \\
Distance $\left(\gamma_{1}\right)$ & 0.002 & \\
\hline Equation (5.6) & & & \\
& $\beta_{1}$ Initial & $\beta_{1}$ Final & $\alpha_{\mathrm{y}}$ \\
$\vartheta_{0}$ & $0.899 * * *$ & $0.797 * * *$ & $-0.326 * * *$ \\
Distance $\left(\vartheta_{1}\right)$ & $-0.007 * * *$ & $-0.005 * * *$ & -0.001 \\
$\vartheta_{2}$ & $-0.139 * * *$ & $0.098 * *$ & $0.046 * *$ \\
Bias $^{1}$ & $-3.22 \%$ & $3.17 \%$ & \\
\hline
\end{tabular}

${ }^{1}$ Bias corresponds to the percent in which the coefficient differs by bias to the coefficient without bias. $\left(\frac{\theta_{2} \gamma_{1}}{A B S\left[\theta_{1}\right.}\right) \& 100$

Level of significance: $*=0.1, * *=0.05$ and $* * *=0.01$

Source: Author's Elaboration.

Moving on, the system of production as an explanatory variable has a significant downward bias on the distance coefficient (Table 5.5), which is according to the expectations. It is important to highlight that the distance coefficient $\left(\vartheta_{1}\right)$ has a negative sign, and then a negative bias actually means an increment in its absolute value. As expected, the positive sign of the significant values of $\vartheta_{2}$ suggests that those relationships with the same system of production are more integrated. This is a reflection of the higher quality of rice produced in the irrigated system in comparison to the rice produced in the upland system.

\section{Table 5. 5}

Effect of Having a Similar Production System

\begin{tabular}{cc} 
Equation (5.7) & \\
$\gamma_{0}$ & $0.702 * * *$ \\
Distance $\left(\gamma_{1}\right)$ & $-0.006 * * *$ \\
\hline
\end{tabular}

\begin{tabular}{cccc}
\hline Equation (5.6) & & & \\
& $\beta_{1}$ Initial & $\beta_{1}$ Final & $\alpha_{\mathrm{y}}$ \\
$\vartheta_{0}$ & $0.776 * * *$ & $0.717 * * *$ & $-0.347 * * *$ \\
Distance $\left(\vartheta_{1}\right)$ & $-0.006 * * *$ & $-0.003 * *$ & 0.005 \\
$\vartheta_{2}$ & $0.124 * * *$ & $0.122 * * *$ & 0.015 \\
Bias $^{1}$ & $-13.2 \%$ & $-23.6 \%$ & \\
\hline
\end{tabular}

${ }^{1}$ Bias corresponds to the percent in which the coefficient differs by bias to the coefficient without bias. $\left(\frac{\theta_{2} \gamma_{1}}{A B S\left(\theta_{1}\right)}\right) \times 100$

Level of significance: $*=0.1, * *=0.05$ and $* * *=0.01$

Source: Author's Elaboration.

The results of GDP and GDP per-capita are displayed in Table 5.6. The decision to divide the variable into three responds to the expectations explained in the sub-Section c of Section 5.3., the effect on integration will differ depending on whether two "large", two "small" or two different sizes of markets in terms of the potential supply and demand (GDP) or in terms of purchasing power (GDP per-capita) are looked at. The expectations are fulfilled only when the GDP per-capita is taken into consideration; there is a higher elasticity when the markets are large and a weaker one among different 
sizes. This can be partly explained by the differences in infrastructure. Regarding GDP, contrary to expectations, only when two markets are small the elasticity is affected, negatively before the changes and positively after. There is not a clear reason for this behavior; however, since GDP does not capture differences of size and population, important issues in Brazil, the results of GDP per-capita, which reflect these disparities, are considered more reliable.

In addition, the expectations of the sign of the relationship between distance and market size, which can be observed in the coefficient $\gamma_{1}$, are satisfied; distance has a positive effect on the probability of finding two similar sized markets and a negative on finding two different sized markets (Table 5.6).

As mentioned earlier, the similarities in infrastructure should have an effect in the integration. This is again supported by the results of the speed of adjustment. First, this is faster in the relationships among large markets (Table 5.6). These markets are located in the South and the SE region, along with Mato Grosso and the Distrito Federal, where certain characteristics, such as the transportation of products and contract use, have a similar and good level of development. Secondly, the sign is negative in the case of two small markets, which is due to the low developmental progress of these markets. Regarding bias, the significant ones have negative values (Table 5.6), meaning downward biases, similar to those presented in Table 5.5.

Table 5. 6

Effect of the Gross Domestic Product GDP and GDP Per-Capita

\begin{tabular}{|c|c|c|c|c|c|c|c|}
\hline & \multicolumn{3}{|c|}{ GDP } & \multicolumn{4}{|c|}{ GDP Per Capita } \\
\hline & $\begin{array}{c}\text { Large } \\
\text { markets }\end{array}$ & $\begin{array}{c}\text { Small and } \\
\text { Large markets }\end{array}$ & Small markets & $\begin{array}{c}\text { Large } \\
\text { markets }\end{array}$ & $\begin{array}{r}\text { Small a } \\
\text { Large }\end{array}$ & & Small markets \\
\hline \multicolumn{8}{|l|}{ Equation (5.7) } \\
\hline$\gamma_{0}$ & $0.274 * * *$ & $0.395 * * *$ & $0.734 * * *$ & $0.320 * * *$ & 0.292 & $2 * * *$ & $0.387 * * *$ \\
\hline Distance $\left(\gamma_{1}\right)$ & $-0.006 * * *$ & 0.004 & $-0.007 * * *$ & $-0.004 * * *$ & 0.009 & $* * *$ & $-0.005 * * *$ \\
\hline \multicolumn{8}{|l|}{ Equation (5.6) } \\
\hline & \multicolumn{7}{|c|}{$\beta_{1}$ Initial } \\
\hline$\vartheta_{0}$ & $0.854 * * *$ & $0.888 * * *$ & $0.956 * * *$ & $0.812 * * *$ & 0.892 & $2 * * *$ & $0.889 * * *$ \\
\hline Distance $\left(\vartheta_{1}\right)$ & $-0.007 * * *$ & $-0.007 * * *$ & $-0.008 * * *$ & $-0.006 * * *$ & -0.006 & $5 * * *$ & $-0.007 * * *$ \\
\hline$\vartheta_{2}$ & 0.057 & -0.046 & $-0.118 * *$ & $0.180 * * *$ & -0.078 & & -0.051 \\
\hline \multirow[t]{2}{*}{ Bias1 } & $-5.3 \%$ & $-2.4 \%$ & $10.6 \%$ & $-12.7 \%$ & -11.19 & & $3.3 \%$ \\
\hline & \multicolumn{7}{|c|}{$\beta_{1}$ Final } \\
\hline$\vartheta_{0}$ & $0.830 * * *$ & $0.808 * * *$ & $0.745 * * *$ & $0.753 * * *$ & 0.848 & $3 * * *$ & $0.832 * * *$ \\
\hline Distance $\left(\vartheta_{1}\right)$ & $-0.005 * * *$ & $-0.005 * * *$ & $-0.004 * * *$ & $-0.004 * * *$ & -0.004 & $4 * * *$ & $-0.005 * * *$ \\
\hline$\vartheta_{2}$ & -0.046 & 0.024 & $0.100 *$ & $0.200 * * *$ & -0.103 & $* * *$ & -0.036 \\
\hline \multirow[t]{2}{*}{ Bias $^{1}$} & $5.7 \%$ & $1.8 \%$ & $-17.4 \%$ & $-22.8 \%$ & -24.59 & & $3.5 \%$ \\
\hline & \multicolumn{7}{|c|}{$\alpha_{y}$} \\
\hline$\vartheta_{0}$ & $-0.329 * * *$ & $-0.322 * * *$ & $-0.352 * * *$ & $-0.341 * * *$ & -0.317 & $7 * *$ & $-0.292 * * *$ \\
\hline Distance $\left(\vartheta_{1}\right)$ & 0.000 & -0.001 & 0.000 & 0.000 & -0.001 & & -0.001 \\
\hline$\vartheta_{2}$ & 0.046 & 0.014 & $0.048 * * *$ & $0.758 * * *$ & 0.001 & & $-0.639 * * *$ \\
\hline \multicolumn{8}{|c|}{${ }^{1}$ Bias corresponds to the percent in which the coefficient differs by bias to the coefficient without bias. $\left(\frac{\theta_{2} \gamma_{1}}{A B S\left(\theta_{1}\right)}\right): 100$} \\
\hline
\end{tabular}


Regarding the final variable, only when the analysis takes into consideration which of the two markets in the relationship is the one which has the port, the results show significant effects. It means that when the variable is split into one market as the leader market and the other as the follower, the presence of a main port near the leader market has a positive effect if after the period of economic changes (Table 5.7). Two points deserve to be emphasized; first, there is only an effect on the leader market, which for many pairs corresponds to a net exporting Southern market. This could mean that the integration is strengthened through a reduction in trade costs by using the maritime route, which is supported by the unexpected positive sign of the significant coefficient. Though it means the estimations of the transfer costs through the constant value need to be improved and the negative distance coefficient could also be related with a reduction in transfer costs, this does not invalidate the fact that there is a bias within the distance coefficient. The second point is the insignificant sign of the coefficient before the structural breaks, which is connected to the deep alterations of the port sector during the 90 's and is a signal of the importance of a port's efficiency, which improved during this period, for the integration between the internal markets.

In order to take the effect of road quality into account, the estimations presented in the third and fourth columns of Table 5.7 included the variable extension of paved roads. Against the expected behavior the results do not vary. However, the road extension of the leader market is the only one which affects the behavior of Beta Final.

On the other hand, the effect on $\alpha_{y}$ is the same either from the follower or the leader market with a significant increase in the velocity when there is a main port (Table 5.7). This could be seen as a reduction in the costs of the flow of information between the Brazilian markets along the coast.

Finally, the significant bias in the presence of a port is the only one with an upward bias sign, meaning that the coefficient which has a bias is higher than the real one. 
Table 5.7

Access to International Markets: Export Points with Ports

\begin{tabular}{|c|c|c|c|c|}
\hline & \multicolumn{2}{|c|}{ Without road extension } & \multicolumn{2}{|c|}{ Including road extension } \\
\hline & $\mathbf{X}$ & $\mathbf{Y}$ & $\mathbf{X}$ & $\mathbf{Y}$ \\
\hline \multicolumn{5}{|l|}{ Equation (5.7) } \\
\hline$\gamma_{0}$ & $0.39 * * *$ & $0.60 * * *$ & $0.24 * * *$ & $0.55 * * *$ \\
\hline Distance $\left(\gamma_{1}\right)$ & $0.01 * * *$ & $-0.01 * * *$ & $0.01 * * *$ & $-0.01 * * *$ \\
\hline \multicolumn{5}{|l|}{ Equation (5.6) } \\
\hline & \multicolumn{4}{|c|}{$\beta_{1}$ Initial } \\
\hline$\vartheta_{0}$ & $0.89 * * *$ & $0.88 * * *$ & $0.93 * * *$ & $0.92 * * *$ \\
\hline Distance $\left(\vartheta_{1}\right)$ & $-0.01 * * *$ & $-0.01 * * *$ & $-0.01 * * *$ & $-0.01 * * *$ \\
\hline$\vartheta_{2}$ & -0.05 & -0.01 & -0.05 & 0.00 \\
\hline Road Extension X & & & 0.00 & 0.00 \\
\hline Road Extension Y & & & 0.00 & 0.00 \\
\hline \multirow[t]{2}{*}{ Bias $^{1}$} & $-3.9 \%$ & $1.1 \%$ & $-5.5 \%$ & $0.4 \%$ \\
\hline & \multicolumn{4}{|c|}{$\beta_{1}$ Final } \\
\hline$\vartheta_{0}$ & $0.77 * * *$ & $0.86 * * *$ & $0.77 * * *$ & $0.84 * * *$ \\
\hline Distance $\left(\vartheta_{1}\right)$ & $-0.01 * * *$ & $-0.01 * * *$ & $-0.01 * * *$ & $-0.01 * * *$ \\
\hline$\vartheta_{2}$ & $0.13 * * *$ & -0.07 & $0.12 * * *$ & -0.07 \\
\hline Road Extension X & & & $0.001 * * *$ & $0.002 * * *$ \\
\hline Road Extension Y & & & -0.002 & -0.002 \\
\hline \multirow[t]{2}{*}{ Bias $^{1}$} & $12.5 \%$ & $10.7 \%$ & $17.1 \%$ & $8.5 \%$ \\
\hline & \multicolumn{4}{|c|}{$\alpha_{y}$} \\
\hline$\vartheta_{0}$ & $-0.33 * * *$ & $-0.37 * * *$ & $-0.36 * * *$ & $-0.40 * * *$ \\
\hline Distance $\left(\vartheta_{1}\right)$ & 0.00 & 0.00 & 0.00 & 0.00 \\
\hline$\vartheta_{2}$ & $0.38 * *$ & $0.08 * * *$ & 0.04 & $0.94 * * *$ \\
\hline Road Extension X & & & 0.00 & 0.00 \\
\hline Road Extension Y & & & 0.00 & 0.00 \\
\hline
\end{tabular}

${ }^{1}$ Bias corresponds to the percent in which the coefficient differs by bias to the coefficient without bias. $\left(\frac{\theta_{2} \gamma_{1}}{\left.A B S C \theta_{1}\right)}\right): 100$

Level of significance: $*=0.1, * *=0.05$ and $* * *=0.01$

Source: Author's Elaboration.

Up to this point we have looked separately at the impact of each variable that influences integration and is also correlated with distance, thus we have an idea of which of these variables are, indeed, correlated with the distance. Nevertheless, some of these variables are correlated among themselves. It means that the estimation of the bias related to each variable is flawed. The reason of that is that the individual bias fails to account for the fact that some of the apparent impact of the related variable on distance is actually an indirect effect of other of the related variables. Therefore, in order to isolate the impact of distance on integration, it is necessary to include a regression containing all of the necessary variables. However, the problem of that is the multicollinearity which makes difficult to measure the variation of distance independent of the other covariates. Nonetheless, in view that the four analyzed variables have a significant effect on integration, and therefore, belong in the regression, the distance coefficient resulting from an equation which includes all the variables is the best unbiased estimation, even if the variation of this coefficient is large.

Table 5.8 shows the results of the three regressions ( $\beta_{1}$ Initial, $\beta_{1}$ Final and $\alpha_{y}$ ) which include the four related variables. First, on the basis of the Likelihood Ratio test, the equation without intercept is 
selected in the three cases. Moreover, the distance effect on the elasticity of cointegration is, as before, weak, negative and significant. Likewise, the results of the variable central market and system of production are the same as in Table 5.4 and 5.5 respectively. In the cases of market size, the three variables are grouped into one, which compares the difference in integration between those relationships with the same size and those with different size in terms of GDP per-capita. The results are similar; two large markets are more integrated than two markets of different sizes. Nevertheless, the integration is significantly weaker between small market than those with different sizes, in both speed of adjustment or long run relationship. This could be, once again, related to the quality of infrastructure that hinders the integration of the less development markets. The only difference is the insignificant effect of the proximity to a main port, however, as in the fourth column of Table 5.7, when the road extension is incorporated the variable becomes, in the case of the leader market, significant. Only the results of the equation with independent variable $\beta_{1}$ Final and which includes the road extension are presented. This is due to the fact that, on the basis of the Likelihood Ratio test, in the other two cases the incorporation of this factor does not improve the estimations.

Table 5.8

Regression Including the Four Related Variables

\begin{tabular}{|c|c|c|c|c|c|c|c|}
\hline Variable & Categories & $\beta_{1}$ Initial & $\beta_{1}$ Final & $\alpha_{y}$ & $\begin{array}{l}\text { Variance } \\
\text { Inflation } \\
\text { Factors }\end{array}$ & $\begin{array}{c}\beta_{1} \text { Final } \\
\text { (Including Road } \\
\text { Extension) }\end{array}$ & $\begin{array}{c}\text { Variance } \\
\text { Inflation } \\
\text { Factors }\end{array}$ \\
\hline Distance & & $-0.006 * * *$ & $-0.004 * * *$ & 0.002 & 5.70 & $-0.006 * * *$ & 6.01 \\
\hline Central Markets & $\begin{array}{l}\text { No } \\
\text { Yes } \\
\end{array}$ & $\begin{array}{l}0.803 * * * \\
0.632 * * * \\
\end{array}$ & $\begin{array}{l}0.666 * * * \\
0.742 * * * \\
\end{array}$ & $\begin{array}{l}-0.396 * * * \\
-0.392 * * *\end{array}$ & 18.52 & $\begin{array}{l}0.708 * * * \\
0.789 * * *\end{array}$ & 19.51 \\
\hline $\begin{array}{l}\text { System of } \\
\text { production }\end{array}$ & $\begin{array}{l}\mathrm{No}^{\dagger} \\
\text { Yes }\end{array}$ & $0.105 * *$ & $0.142 * * *$ & 0.031 & 2.80 & $0.154 * * *$ & \\
\hline $\begin{array}{l}\text { Market Size: } \\
\text { GDP per-capita }\end{array}$ & $\begin{array}{l}\text { Small and Large } \dagger \\
\text { Large markets } \\
\text { Small markets }\end{array}$ & $\begin{array}{l}0.188 * * * \\
-0.097 *\end{array}$ & $\begin{array}{l}0.174 * * * \\
-0.017\end{array}$ & $\begin{array}{r}0.053 * \\
-0.049 * \\
\end{array}$ & 2.47 & $\begin{array}{l}0.257 * * * \\
-0.052\end{array}$ & \\
\hline $\begin{array}{l}\text { Close to an } \\
\text { important port: } X\end{array}$ & $\begin{array}{l}\text { No† } \\
\text { Yes }\end{array}$ & 0.001 & 0.079 & 0.0288 & 3.13 & $0.117 *$ & 3.78 \\
\hline $\begin{array}{l}\text { Close to an } \\
\text { important port: } Y\end{array}$ & $\begin{array}{l}\text { Noł } \\
\text { Yes }\end{array}$ & 0.014 & -0.058 & $0.0826 * * *$ & 1.72 & -0.015 & 1.95 \\
\hline Road Extension X & & & & & & -0.003 & 1.92 \\
\hline Road Extension Y & & & & & & $-0.008 * * *$ & 1.82 \\
\hline
\end{tabular}

$\uparrow$ Base Category

Level of significance: $*=0.1, * *=0.05$ and $* * *=0.01$

Source: Author's Elaboration. 


\subsection{Conclusions}

Integration has been considered a good approximation of market performance. Moreover, in view of the possible spread of the effects of policy measures within integrated markets, through the adjustment of prices, integration is a main issue to consider in light of policy changes and improvements. Understanding the degree of the integration and the variables which influence it is therefore important. The geographical distance between markets has been pointed out as a significant variable in the determination of integration. Explanations within literature have focused on the raise of transfer costs when distance increases. However, the supposition behind the application of the cointegration framework to analyze the validity of the LOP is that the constant value of the long run equation can be considered a good approximation of the transfer costs, meaning that the estimation of the integration measurement is free from the effect of the transfer costs. The proposition presented here is that there are other variables which explain a possible significant effect of distance, since they are related to it and have an effect on market integration at the same time. In order to investigate the validity of this proposal, the integration of Brazil's rice markets has been estimated, along with an analysis of the effects of four selected variables which could change with distance.

The period of investigation, 1990-2006, is characterized by a sequence of strong economic transformations which also had an impact on the agricultural sector. To consider this, the analysis allows for the presence of two structural breaks at the most in the long run equation. The cointegration relationships present the first significant structural change mostly during the time of the application of the stabilization plans (1991-1994), and the second one after the crop failure in Rio Grande do Sul (2003-2004) and at the time of the crisis resulting from the Real plan (1995-1998).

When looking at the effect of distance on integration, although it shows a negative and significant relationship with the elasticity of cointegration, the relationship is weak; a variation of 10 hours changes the integration by only 0.07. Moreover, there is not a relationship with the speed of adjustment. The later could be linked to the fact that distance does not reflect changes in weather; however, there has not been a distance estimation which has included this variable.

Concerning the related variables, although there is not a significant bias when the presence of a central market in the relationship is considered, this variable has a significant impact on the integration measures. This impact is negative before the economic changes and positive after, reflecting the intensification of central markets' importance, which present signals of increase.

Regarding the system of production, its omission causes a downward significant bias on the distance coefficient. Moreover, a relationship between two markets with the same system of production has a higher elasticity coefficient and a faster adjustment. This reflects the differences of rice quality between the two systems of production in Brazil: irrigated/lowland and aerobic/upland rice.

Next, the results indicate that those relationships between two large markets in terms of GDP percapita have a stronger and faster integration. Moreover, different sizes of markets have a weaker 
relationship, which is explained by the dissimilarities in transportation services. Likewise, a relationship of two small markets adjusts slower to the long run equilibrium. Regarding the bias, it is negative and larger after the period of economic changes.

Finally, the presence of a main port close to the leader market has a positive effect after the period of economic changes. This significant positive sign shows that the Southern producers, which are mostly leading markets, are taking advantage of the access to ports to export to the North and NE markets. It indicates that the transfer costs are not completely considered by the constant coefficient of the long run equation; however, it does not invalidate the fact that there is a bias on the distance coefficient. In addition, the importance of the variable increased after the structural break, which is displayed by the insignificant effect on the Initial Beta. This is linked with the improvement in the quality of ports during the 90's. Today, Brazil is becoming an exported oriented country with a high participation in international markets. This puts more pressure on the enhancement of port efficiency, and it can thus be expected that the importance of ports for market integration will increase in the near future. Finally, this is the only variable for which bias on the distance coefficient is negative.

In conclusion, three out of our four variables cause a bias of between $10 \%$ and $25 \%$ of the real distance value coefficient with their omission. This proves that although distance has an effect on integration, this is partly explained by the dissimilarities between markets which increase with more distance between them. Taking that into consideration, it would be interesting to analyze the effect of the related variables on international integration. Obviously the number of related variables worldwide is higher and the differences are stronger: religion, language, level of development, education, quality of services and even moral standards. The overall point is that focusing only on geographical distance or transfer costs does not sufficiently explain how integration is defined and how it could develop in the future.

\subsection{References}

Agência Agência Nacional de Transportes Aquaviários (ANTAQ); (2006). "Anuário Estatístico Portuário, 2006”. Brasilia/DF, Brazil: Brazilian Government (http://www.antaq.gov.br/Portal/Estatisticas_Anuarios.asp).

Agência Agência Nacional de Transportes Aquaviários (ANTAQ); (2009). “Anuário Estatístico Portuário, 2009”. Brasilia/DF, Brazil: Brazilian Government (http://www.antaq.gov.br/Portal/Estatisticas_Anuarios.asp).

Agência Nacional de Transpotes Terrestes (ANTT); (2008). "Anuário Estatístico dos Transportes Terrestes, AETT/2008”. Brasilia/DF, Brazil: Brazilian Government (http://www.antt.gov.br/InformacoesTecnicas/aett/aett_2008/principal.asp).

American Association of Port Authorities (AAPA); ( 2009). "World Port Rankings, 2009”. Alaexandria, Virginia, USA. (http://aapa.files.cms-plus.com/PDFs/WORLD\%20PORT\%20RANKINGS\%202009.pdf).

Ardeni, P.G.; (1989). "Does the Law of One Price Really Hold for Commodity Prices?”. American Journal of Agricultural Economics, 71(3) pp 661-69. 
Bai, J., \& P. Perron; (1998). "Estimating and Testing Linear Models with Multiple Structural Changes”. Econometrica, 66(1) pp 47-78.

Baulch, B.; (1997). "Transfer Costs, Spatial Arbitrage, and Testing for Food Market Integration". American Journal of Agricultural Economics, 79 (2) pp 477-487.

Bergstrand, J.; (1985). “The Gravity Equation in International Trade: Some Microeconomic Foundations and Empirical”. The Review of Economics and Statistics, 67 (3) pp 474-48.

Blonigen, B., \& W. Wilson; (2006). "New Measures of Port Efficiency Using International Trade Data”. NBER Working Paper Series, 12052.

Cárdenas, J.; (2006). "Itajaí: Experiencia de Éxito en Administración Portuaria Municipal". Thesis to obtained the grade of Marine Engineer, Faculty of Engineering Sciences, University Austral of Chile. Valdivia, Chile.

Companhia Nacional de Abastecimento (CONAB); (Consulting January 2011). "Fluxo de Importação e Exportação das Regiões Brasileiras”. Superintendência de Gestão da Oferta (Sugof), Gerência De Alimentos Básicos (Gerab). (www.conab.gov.br/).

a. Companhia Nacional de Abastecimento (CONAB); (Consulting August 2011). "Arroz Série Histórica”. Brazil: Brazilian Government (www.conab.gov.br/conabweb/download/safra/ArrozSerieHist.xls)

b. Companhia Nacional de Abastecimento (CONAB); (August 2011). Data provided directly by CONAB per request.

Cramer, G., E. Wailes \& S. Shui; (1993). "Impacts of Liberalizing Trade in the World Rice Market". American Journal of Agricultural Economics, 75 (1) pp 219-226.

Costa Crusciol, C.A., O. Arf, R. Peres, \& G. Pavan; (2008). "Grain Quality of Upland Rice Cultivars in Response to Cropping Systems in the Brazilian Tropical Savanna”. Scientia Agricola, 65(5) pp 468-473.

Cristovão dos Santos, R.A., \& E. Amaral; (2007) "Eficiência Relativa dos Portos Brasileiros: Uma Análise Regionalizada". Series Anais do XXXV Encontro Nacional de Economia No. 87, Associação Nacional dos Centros de Pósgraduação em Economia (ANPEC).

da Silva, S., \& E. Delgado; (2001). "Regional Climatic Risk Zoning for Upland Rice in the States of Goiás, Mato Grosso, Mato Grosso do Sul, Minas Gerais, Tocantis and Bahia, Brazil”. Revista Brasileira de Agrometeorologia Passo fundo, 9(3) pp 536-543.

da Silva, A., \& G. Dalla; (2009).“O Comércio Internacional do Arroz no Contexto do Mercosul no Período de 1990-2005”. Paper presented at the XLVII Congresso da Sociedade Brasileira de Economia, Administração e Sociologia Rural, Brazil.

de Castro, E., N. de Almeida, R. Rabelo \& S. da Silva; (1999). "Qualidade de Grãos em Arroz”. San Antõnio de Goiás, Brazil: Embrapa Arroz e Feijão.

de Oliviera Adami, A., G. S. de Camargo, \& M. Rumenos Piedade. (2008). “Contratos de Opção: Análise do Potecial de Sustentação de Preços Para o Mercado de Arroz”, Revista Economia e Sociologia Rural, 46(1) pp 229-247.

de Sá Porto, P.C.; (2002). "MERCOSUL and Regional Development in Brazil: A Gravity Model Approach". Revista de Estudos Econômicos, 32(1) pp 125-153.

Dolado, J., \& H. Luetkepohl; (1996). "Making Wald Tests Work for Cointegrated VAR Systems". Econometric Reviews, Taylor and Francis Journals, 15(4) pp 369-386.

Döring, T., \& J. Schnellenbach; (2006). "What do We Know about Geographical Knowledge Spillovers and Regional Growth?: A Survey of the Literature” Regional Studies, 40(3) pp 375-395. 
dos Santos, A., \& others; (2005). . “Consumo, Mercado e Comercialização do Arroz no Brasil”, in a D. Petis, D. Lessa and E. da Rosa Freire (eds.), Cultivo do Arroz Irrigado no Brasil. Sistemas de Produção, Embrapa Clima Temperado (ISSN 18069207) (http://sistemasdeproducao.cnptia.embrapa.br/FontesHTML/Arroz/ArrozIrrigadoBrasil/cap18.htm).

Dutoit, L., K. Hernández \& C. Urrutia; (2010) “Transmisión de Precios en los Mercados del Maíz y Arroz en América Latina”. Series CEPAL: Desarrollo Productivo No. 190. The Economic Commission for Latin America and the Caribbean, United Nations (ISBN: 978-92-1-323464-8).

Empresa Brasileira de Pesquisa Agropecuária (Embrapa); (2011). “Cultivares da Embrapa Melhoram a Qualidade do Arroz em MT”. (http://www.embrapa.br/embrapa/imprensa/noticias/2011/maio/1a-semana/cultivares-da-embrapa-melhoram-aqualidade-do-arroz-em-mt).

Engel, C., \& J.H. Rogers; (1996). “How Wide is the Border?”. American Economic Review, 86(5) pp 1112- 1125.

Engle, R. F., \& C.W. J. Granger; (1987). "Cointegration and Error Correction: Representation Estimation and Testing.” Econometrica, 55 pp 251-276.

Escobal, J., \& A. Vásquez; (2008). "Market Integration for Agricultural Output Markets in Peru: The Role of Public Infrastructure”. Quarterly Journal of International Agriculture, 47 (1) pp 25-47.

Fackler, P., \& B. Goodwin; (2001). "Spatial Price Analysis". in a B. L. Gardner and G. C. Rausser (eds.), Handbook of Agricultural Economics 1. Elsevier Science B.V., 970-1024.

Food and Agriculture Organization of the United Nations (FAO); (Consulted October 2010). "FAOSTAT”. United Nations. (http://faostat.fao.org/site/345/default.aspx).

a. Food and Agriculture Organization of the United Nations (FAO); (Consulted October 2010). "International Year of Rice 2004: Rice around the Word. Brazil” (http://www.fao.org/rice2004/en/p1.htm).

Francois, J., \& M. Machin; (2007). “Institutions, Infrastructure, and Trade”. The World Bank, Series Policy Research, 4152.

Frankel, J., E. Stein \& S-J. Wei; (1995). "Trading Blocs and the Americas: The Natural, the Unnatural and the Supernatural". Journal of Development Economics, 47 pp 61-95.

Ghoshray, A.; (2008). “Asymmetric Adjustment of rice Export Prices: The Case of Thailand and Vietnam”. International Journal of Applied Economics, 5(2) pp 80-91.

Goletti, F., R. Ahmed, \& N. Farid; (1995). "Structural Determinants of Market Integration: The Case of Rice Markets in Bangladesh". The Developing Economies, 33(2) pp 196-198.

Gonzáles, G., \& S. Helfand; (2001). "The Extent, Pattern, and Degree of Market Integration: A Multivariate Approach for the Brazilian Rice Market”. American Journal of Agricultural Economics, 83(3) pp 576-592.

Goodwin, B.K.; (1992). "Multivariate Cointegration Tests and the Law of One Price in International Wheat Markets". Review of Agricultural Economics, 14(1), 117-24.

Granger, C.W.J.; (1969). "Investigating Causal Relations by Econometric Models and Cross-Spectral Methods". Econometrica, 37(3) pp 424-438.

Gregory, A.W., \& B.E. Hansen; (1996). "Residual Based Tests for Cointegration in Models with Regime Shifts". Journal of Econometrics, 70(1) pp 99-126.

Guanziroli, C.; (1999). "Reforma Egraria y Globalización de la Economía: El Caso de Brasil”. Proyecto de Cooperación Técnica INCRA/FAO.

Hamilton, J.; (1994). “Time Series Analysis”. Princeton NJ: Princeton University Press. 
Helfand, S., \& G. Castro; (2001). "Brazilian Agriculture in the 1990's: Impact of the Policy Reforms”. Discussion Paper No. 785, Instituto de Pesquisa Econômica Aplicada (IPEA), Rio de Janeiro (ISSN 1415-4755).

Honaker, J., G. King \& M. Blackwell; (2009) “Amelia II: A Program for Missing Data. Version 1.2-0”. The R Project for Statistical Computing (http://cran.r-project.org/web/packages/Amelia/vignettes/amelia.pdf).

Ihle, R., S. von Cramon-Taubadel, \& S. Zorya; (2011). "Measuring the Integration of Staple Food Markets in Sub-Saharan Africa: Heterogeneous Infrastructure and Cross Border Trade in the East African Community”. Working Paper 3413, Category 8: Trade Policy, CESifo.

Inoue, F. ; (2008). "Geographical Distance Center and Multivariate Analysis of the Standard Japanese". Dialectologia, 1 pp 65-81.

Instituto Brasileiro de Geografia e Estatísticas (IBGE); (Consulted May 2010)."Pesquisa de Orçamentos Familiares 20022003." Diretoria de Pesquisas, Coordenação de Índices de Preços. Brasilia/DF, Brazil: Brazilian Government (http://www.ibge.gov.br/home/estatistica/populacao/condicaodevida/pof/2002aquisicao/tab16.pdf).

a. Instituto Brasileiro de Geografia e Estatísticas (IBGE); (Consulted May 2010). “Censo Agropecuário 2006”. Brasilia/DF, Brazil: Brazilian Government (http://www.ibge.gov.br/home/estatistica/economia/agropecuaria/censoagro/default.shtm).

Instituto Brasileiro de Geografia e Estatísticas (IBGE); (Consulted March 2011). "Producto Interno Bruto dos Municípios 2004-2008". Brasilia/DF, Brazil: Brazilian Government (http://www.ibge.gov.br/home/estatistica/economia/pibmunicipios/2004_2008/defaulttab.shtm)

a. Instituto Brasileiro de Geografia e Estatísticas (IBGE); (Consulted March 2011). "Censos Demográficos". Brasilia/DF, Brazil: Brazilian Government (http://www.ibge.gov.br).

Instituto de Pesquisa Econômica Aplicada (IPEA); (2010). "Portos Brasileiros: Diagnóstico, Políticas e Perspectivas". Série Eixos do Desenvolvimiento Brasileiro, 48.

Instituto Nacional de Meteorologia (INMET); (Consulting June 2011). "Normais climatológicas do Brasil 1961-1990". (http://www.inmet.gov.br/html/clima.php\#).

Jales, J., \& A. Barrantes; (2009). “Comércio Inter-Estadual e Comércio Exterior das Regiões Brasileiras e Intergração Regional: Uma Estimativa Utilizando a Equação Gravitacional”. paper presented at the Forum BNB de Desenvolvimento, Brazil (http://www.bnb.gov.br/content/aplicacao/eventos/forumbnb2009/docs/comercio.pdf).

Kejriwal, M., \& P. Perron; (2010). "Testing for Multiple Structural Changes in Cointegrated Regression Models". Journal of Business \& Economic Statistics - American Statistical Association, 28(4) pp 503-522.

King, G., J. Honaker, A. Joseph, \& K. Scheve; (2001). “Analyzing Incomplete Political Science Data: An Alternative Algorithm for Multiple Imputations”. American Political Science Review, 95(1) pp 49-69.

Kirchgässner, G., \& J. Wolters; (2007). "Introduction to Modern Time Series Analysis”. Springer-Verlag Berlin Heidelberg. (ISBN 978-3-540-68735-1).

Kuan, C.-M., \& K. Hornik; (1995). “The Generalized Fluctuation Test: A Unifying View”. Econometric Reviews, 14(2) pp $135-161$.

Kyvik, H., \& R. Piermartini; (2004). "Infrastructure and Trade". Staff Working Paper ERSD-2004-04, World Trade Organization Economic Research and Statistics Division.

Limão, N., \& A.J. Venables; (2001). "Infrastructure, geographical disadvantage, transport costs and trade". The World Bank Economic Review, 15(3) pp 451-479.

Marion, P.J., \& N. Eich Einloft; (2008). “Competitividade do Arroz Irrigado Brasileiro No Mercosul: The Competitiveness of Brazilian Irrigated Rice in Mercosul”. Rural and Agro-Industrial Organizations, 10 (1) pp 11-22. 
McKenzie, A., \& V. Pede; (2005) "Integration in Benin Maize Market: An Application of Threshold Cointegration Analysis" paper presented at the American Agricultural Economics Association Annual Meeting, Providence, Rhode Island.

Miljkovic, D.; (1999). “The Law of One Price in International Trade: A Critical Review”. Review of Agricultural Economics, 21(1) pp 126-139.

Ministerio da Agrícultura, Pecuária e Abastecimiento du Brasil, (MAPA);(Consulted October 2010). “Datos Estadísticos”. Brasilia/DF, Brazil: Brazilian Government (http://www.agricultura.gov.br)

Ministério do Desenvolvimento, Indústria e Comércio Exterior (MDIC); (Consulting April 2011). "ALICE web Data Base”. Brasilia/DF, Brazil: Brazilian Government. (http://aliceweb.desenvolvimento.gov.br/)

Parzen, E.; (1962). "On Estimation of a Probability Density Function and Mode”. Annals of Mathematical Statistics, 33(3) pp $1065-1076$

Paz, L.S., \& A. Arinos de Mello Franco; (2003). "Brazilian Border and Mercosul Integration Effects: An Exploratory Assessment Using the Gravity Model paper presented at the 31th Brazilian Economics Meeting, Brazilian Association of Graduate Programs in Economics, Brazil.

Peschel, K.; (1981). "On the Impact of Geographic Distance on the Interregional Patterns of Production and Trade" Environment and Planning, 13(5) 605-622.

Pfaff, B.; (2006). “Analysis of Integrated and Cointegrated Time Series with R”. New York: Springer.

Rapsomanikis, G., D. Hallam, \& P. Conforti; (2003). "Market Integration and Price Transmission in Selected Food and Cash Crop Markets of Developing Countries: Review and Applications”. Commodity Market Review, 2003-2004. Rome: FAO.

Rapsomanikis, G., \& P. Karfakis; (2004). "Margins across Time and Space: Threshold Cointegration and Spatial Pricing Applications to Commodity Markets in Tanzania", paper present at the Workshop Staple Food Trade and Market Policy Options for Promoting Development in Eastern and Southern Africa, FAO, Rome.

Ravallion, M.; (1986). “Testing Market Integration”. American Journal of Agricultural Economics, 68(1) pp 102-109.

Sanogo, I.; (2008). "Spatial Integration of Rice Market Empirical Evidence from Mid-West and Far West Nepal and the Nepalese-Indian Border”. Asian Journal of Agriculture and Development, 4 (1), pp 139-156.

Tinbergen, J.; (1962). "Shaping the World Economy: Suggestions for an International Economic Policy”. New York: The Twentieth Century Fund.

United Nation Development Programme (UNDP). (Consulted July 2011).”Human Development Index (HDI)”. (www.pnud.org.br/pobreza_desigualdade/reportagens/index.php?id01=3039\&lay=pde).

Vinod, T. ;(2006). "From Inside Brazil: Development in a Land of Contrast”. Washintong, DC: The Word Bank (ISBN-10:08213-6455-3).

von Cramon-Taubadel, S.; (1998). "Estimating asymmetric price transmission with the error correction representation: An application to the German pork market". European Review of Agricultural Economics, 25(1) pp. 1-18.

Wander, A., S. de Miranda \& C. Magri; (2008). "The Competitiveness of Brazilian Rice in the World Market: A Comparative Advantage Approach". paper presented at the Tropentag Conference, Competition for Resources in a Changing World: New Drive for Rural Development, Stuttgart-Hohenheim, Germany.

Wooldridge, J.; (2010). "Econometric Analysis of Cross Section and Panel Data: Second Edition". MIT Press Cambrige, Massachusetts, London England.

YOU, L.; (2008). "A Tale of Two Countries: Spatial and Temporal Patterns of Rice Productivity in China and Brazil”. Research Paper No. 2008/30, United Nations University (UNU) - World Institute for Development Economic Research (WIDER). 


\section{Annex 5.1}

\section{Distribution of Brazil's States}

Figure 5.6

Regions of Brazil

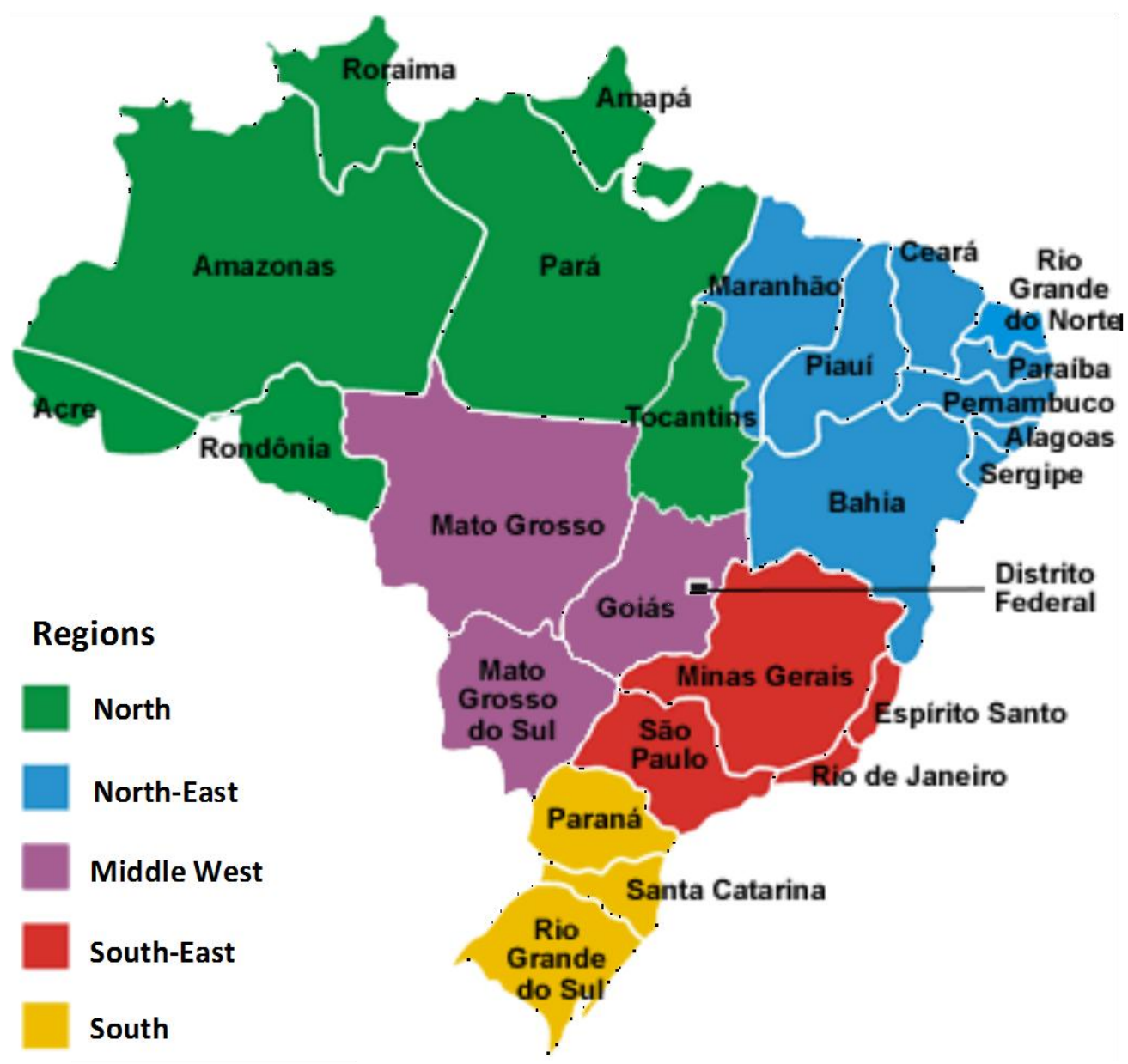




\section{Annex 5.2}

\section{Characteristics of the Price Series}

Table 5.9

States and Periods Included in the Investigation

\begin{tabular}{lcclcc}
\hline & Start & End & & Start & End \\
\hline Acre & $1990 \mathrm{~m} 2$ & $2006 \mathrm{~m} 1$ & Paraíba & $1990 \mathrm{~m} 2$ & $2006 \mathrm{~m} 1$ \\
Alagoas & & & Paraná & $1990 \mathrm{~m} 2$ & $2006 \mathrm{~m} 1$ \\
Amapá & & & Pernambuco & $1990 \mathrm{~m} 2$ & $2006 \mathrm{~m} 1$ \\
Amazonas & $1990 \mathrm{~m} 2$ & $2006 \mathrm{~m} 1$ & Piauí & $1990 \mathrm{~m} 2$ & $1999 \mathrm{~m} 4$ \\
Bahia & $1990 \mathrm{~m} 2$ & $2006 \mathrm{~m} 1$ & Rio de Janeiro & $1990 \mathrm{~m} 2$ & $2006 \mathrm{~m} 1$ \\
Distrito Federal & $1990 \mathrm{~m} 2$ & $2006 \mathrm{~m} 1$ & Rio Grande do Norte & $1990 \mathrm{~m} 2$ & $1999 \mathrm{~m} 7$ \\
Ceará & $1990 \mathrm{~m} 2$ & $2006 \mathrm{~m} 1$ & Rio Grande do Sul & $1990 \mathrm{~m} 2$ & $2006 \mathrm{~m} 1$ \\
Espirito Santo & $1990 \mathrm{~m} 2$ & $2006 \mathrm{~m} 1$ & Rondônia & $1990 \mathrm{~m} 2$ & $2006 \mathrm{~m} 1$ \\
Goiás & $1990 \mathrm{~m} 2$ & $2006 \mathrm{~m} 1$ & Roraima & $1990 \mathrm{~m} 2$ & $1998 \mathrm{~m} 2$ \\
Maranhão & $1990 \mathrm{~m} 2$ & $2006 \mathrm{~m} 1$ & Santa Catarina & $1990 \mathrm{~m} 2$ & $2004 \mathrm{~m} 5$ \\
Mato Grosso & $1990 \mathrm{~m} 2$ & $2006 \mathrm{~m} 1$ & São Paulo & $1990 \mathrm{~m} 2$ & $2006 \mathrm{~m} 1$ \\
Mato Grosso do Sul & $1990 \mathrm{~m} 2$ & $2006 \mathrm{~m} 1$ & Sergipe & $1990 \mathrm{~m} 2$ & $2000 \mathrm{~m} 10$ \\
Minas Gerais & $1990 \mathrm{~m} 2$ & $2006 \mathrm{~m} 1$ & Tocantins & $1990 \mathrm{~m} 2$ & $2006 \mathrm{~m} 1$ \\
Pará & $1990 \mathrm{~m} 2$ & $2006 \mathrm{~m} 1$ & & & \\
\hline
\end{tabular}

Source: Author's Elaboration.

Table 5. 10

Result of the Unit Root Test

\begin{tabular}{lclc}
\hline \multicolumn{1}{c}{ REGION } & Unit Root Test Results & \multicolumn{1}{c}{ REGION } & Unit Root Test Results \\
\hline Acre & $\mathrm{I}(1) / \mathrm{I}(0)$ & Brazil & $\mathrm{I}(1) / \mathrm{I}(0)$ \\
Alagoas & No Data & Paranába & $\mathrm{I}(1)$ \\
Amapá & No Data & Pernambuco & $\mathrm{I}(1) / \mathrm{I}(0)$ \\
Amazonas & $\mathrm{I}(1)$ & Piauí & $\mathrm{I}(1) / \mathrm{I}(0)$ \\
Bahia & $\mathrm{I}(1) / \mathrm{I}(0)$ & Rio de Janeiro & $\mathrm{I}(1) / \mathrm{I}(0)$ \\
Distrito Federal & $\mathrm{I}(1)$ & Rio Grande do Norte & $\mathrm{I}(1)$ \\
Ceará & $\mathrm{I}(1)$ & Rio Grande do Sul & $\mathrm{I}(1)$ \\
Espirito Santo & $\mathrm{I}(1) / \mathrm{I}(0)$ & Rondônia & $\mathrm{I}(\mathbf{0})$ \\
Goiás & $\mathrm{I}(1) / \mathrm{I}(0)$ & Roraima & $\mathrm{I}(1)$ \\
Maranhão & $\mathrm{I}(1)$ & Santa Catarina & $\mathrm{I}(1)$ \\
Mato Grosso & $\mathrm{I}(1) / \mathrm{I}(0)$ & São Paulo & $\mathrm{I}(1)$ \\
Mato Grosso do Sul & $\mathrm{I}(1) / \mathrm{I}(0)$ & Sergipe & $\mathrm{I}(1)$ \\
Minas Gerais & $\mathrm{I}(1)$ & Tocantins & $\mathrm{I}(1)$ \\
Pará & $\mathrm{I}(1) / \mathrm{I}(0)$ & & \\
\hline
\end{tabular}

Source: Author's Elaboration. 
Figure 5.7

Rice Prices of the Northern Region of Brazil (Dollars per Kilo)

1990/2 - 2006/1

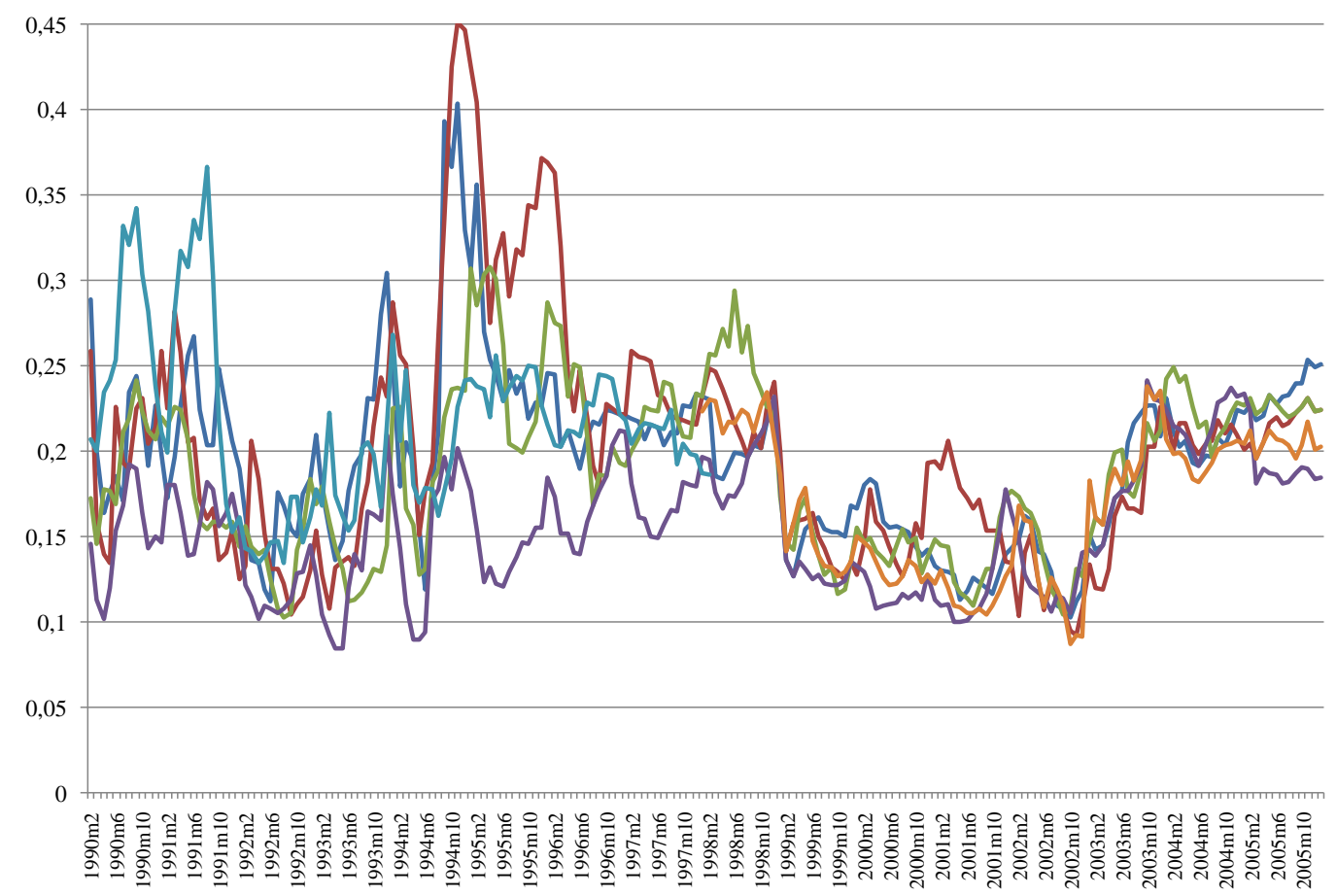

—Acre - Amazonas —Pará —Rondônia — Roraima — Tocantins

Source: Author's Elaboration. Data: ECLAC Chile

Figure 5.8

Rice Prices of the Northeastern Region of Brazil (Dollars per Kilo)

1990/2 - 2006/1

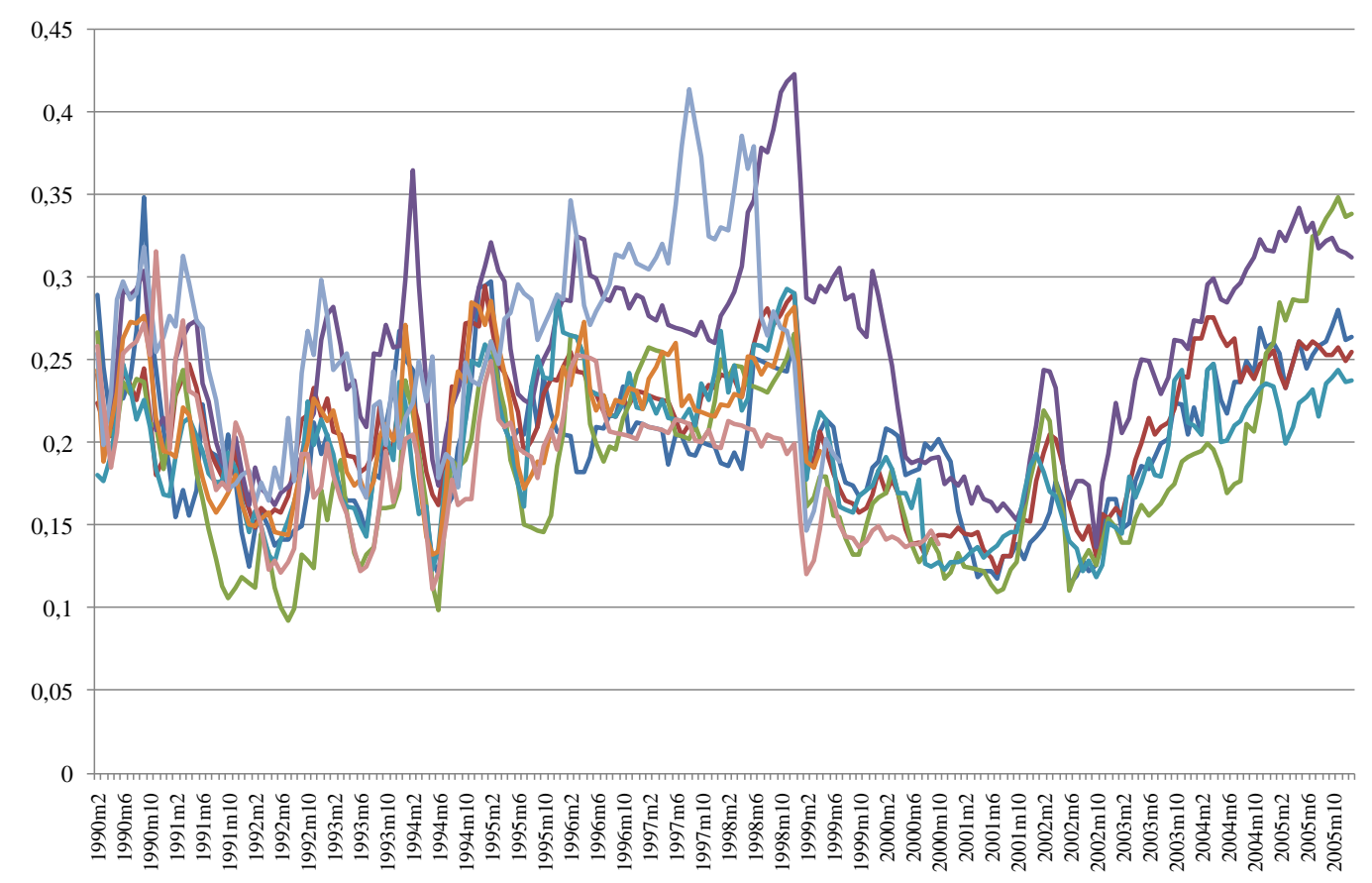

—Bahia — Ceará — Maranhão — Paraíba — Pernambuco — Piauí — Rio Grande do Norte — Sergipe Source: Author's Elaboration. Data: ECLAC Chile 
Figure 5.9

Rice Prices of the Middle Western Region of Brazil (Dollars per Kilo)

1990/2 - 2006/1

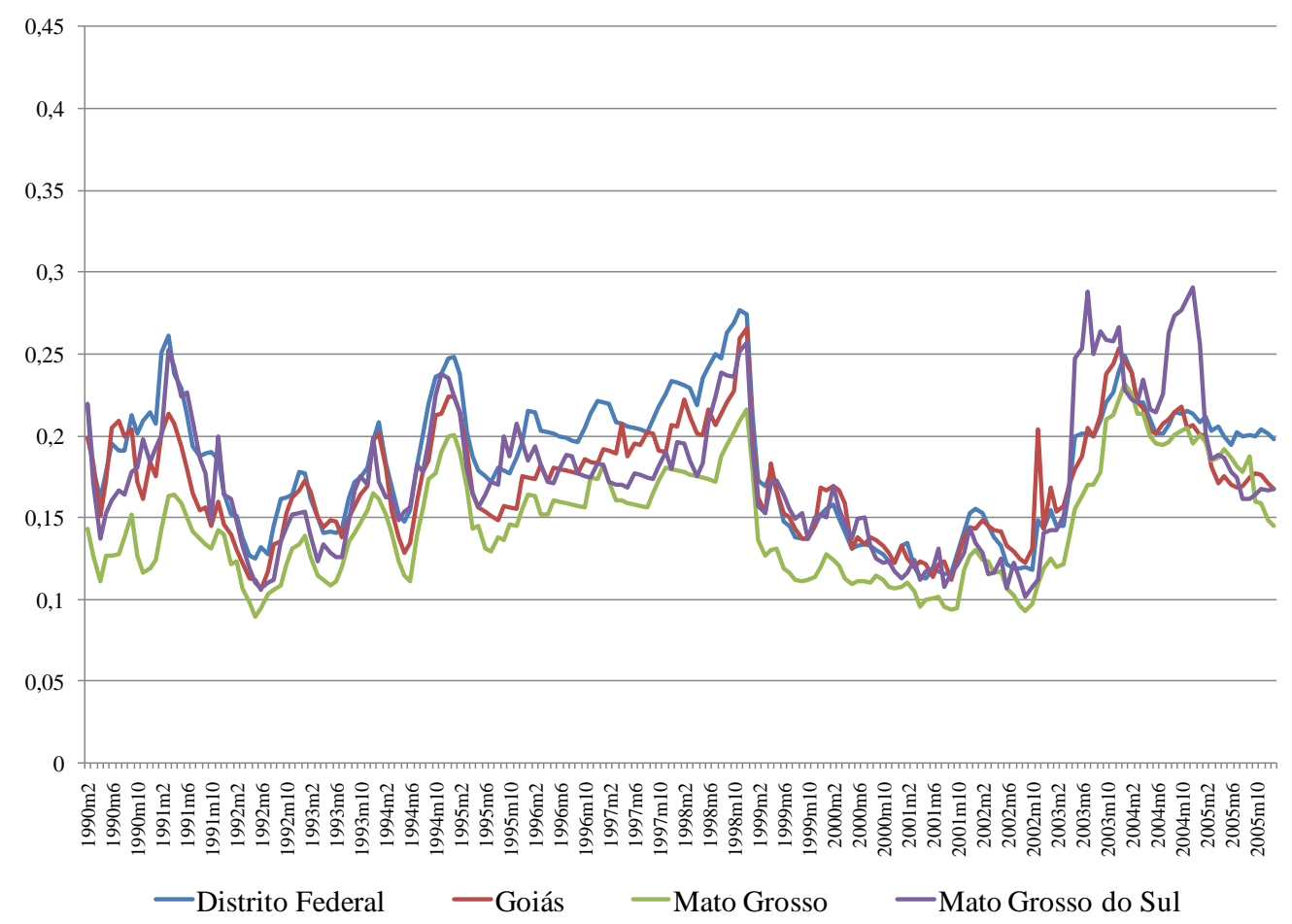

Source: Author's Elaboration. Data: ECLAC Chile

Figure 5. 10

Rice Prices of the Southeast and South Regions of Brazil (Dollars per Kilo)

1990/2 - 2006/1

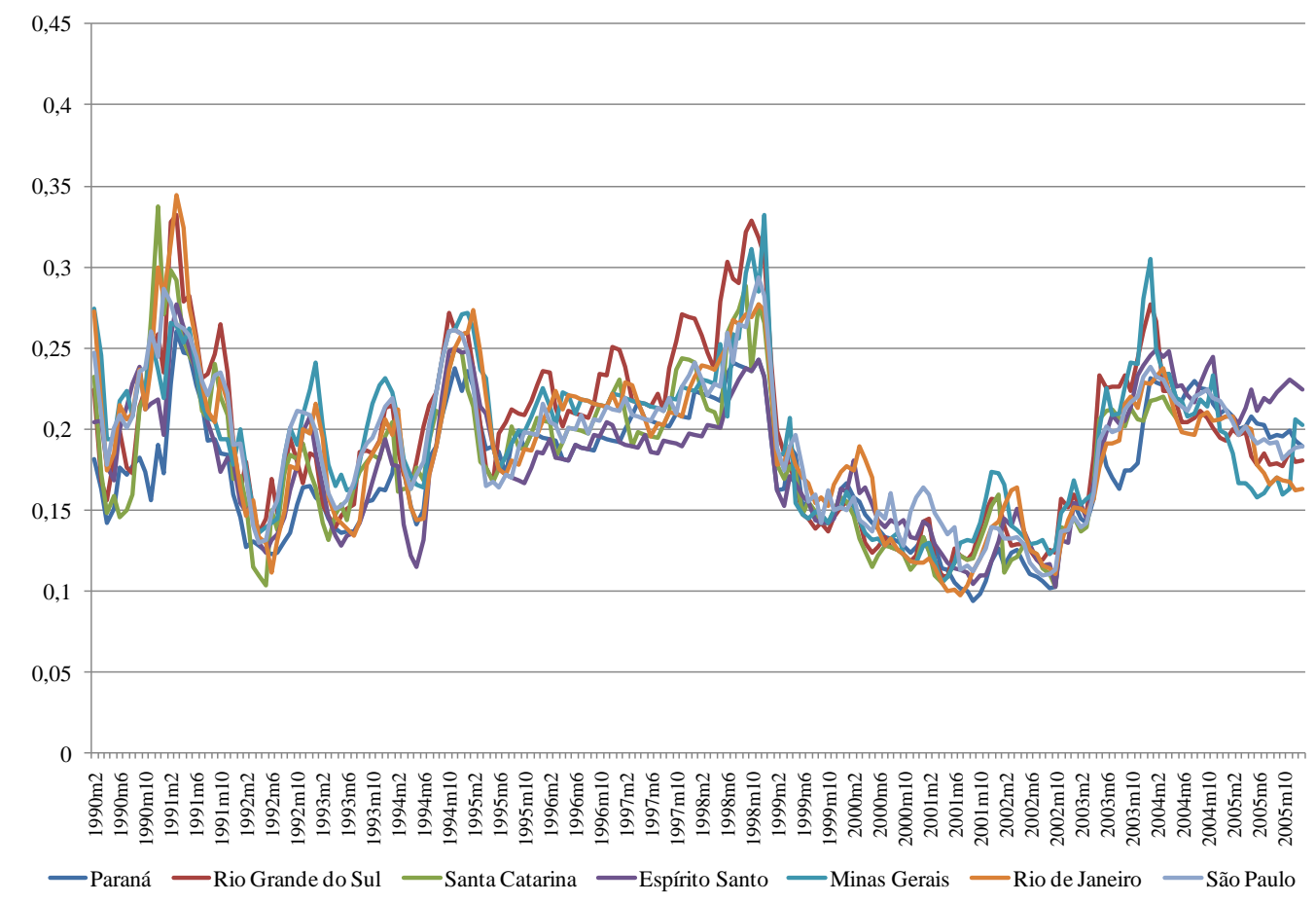

Source: Author's Elaboration. Data: ECLAC Chile 


\section{Chapter 6}

\section{Spatial Price Transmission of the Rice Market of Northeastern Brazil and the Variables which Affect It}

\subsection{Introduction}

Brazil, the fifth biggest country in the world, is characterized by deep contrasts (Vinod, 2006). Divided into five regions and twenty-six states, one of the country's principle disparities is its socioeconomic development, with the southeastern (SE) region having a per-capita income twice that of the northern (N) and three times as much as the northeast (NE) (IBGE, 2011). The NE is the least developed and the second most isolated region, being home to the poorest people. $26 \%$ (50 million) of Brazilians live here with $77.1 \%$ of the municipalities having more than $50 \%$ of the population under the poverty line (IBGE, 2008).

In this region, rice is a major staple food, making its per-capita consumption the second highest within the country. Here rice represents $16.8 \%$ of the daily per-capita calories (IBGE, 2010). Therefore, the framework of rice markets in the NE region can be considered closely related with the quality of life of the poorest people in the country. In view of that, a main issue is the effect of trading partners on the NE rice market, for which integration is then central. According to CONAB (2011), the NE imports around $75 \%$ of its total rice consumption. Since three of the five Brazilian regions have a surplus of rice (CONAB, 2011), one may think that the NE, as a significant buyer, would play a central role among rice markets; however, long distances together with the quality of roads hinder transactions. Perobelli and Haddad (2003) suggest the existence of small interactions of the NE with the majority of other regions. In addition, its relevance as a consumer is eclipsed by the SE, which has better infrastructure and imports around twice as much as the NE (CONAB, 2011).

In spite of the NE's trade difficulties, this region has a key advantage: access to the coast. Limão and Venables (2001) found that overland distance is around 7 times more expensive than sea distance, and being landlocked increases transport costs by approximately 50\%. This characteristic creates an interesting market for products coming from Argentina and Uruguay, net rice exporters whose principal destination is Brazil. Production costs in Argentina and Uruguay are far below those of Brazil, creating difficulties regarding the competition of Brazil's farmers and negative affecting their stability (Marion \& Eich, 2008). However, the poor efficiency of the NE's ports is a disincentive and a hurdle for imports. According to Cazuza et al. (2008), the majority of ports which handle containers or low added value products can be considered inefficient. 
Recalling the aforementioned, market integration is an important issue here. The ambiguity of being a region with a high-level of consumption but isolated by the quality of the infrastructure, and being connected to the international market by coast but with a low efficiency of ports, makes it difficult to detect which of the suppliers are more connected to the rice market of the NE. One way to answer this question is to analyze the degree to which market shocks are transmitted across spatially-distinct markets. Spatial price transmission refers to co-movements of prices and, more generally, to the smooth transmission of price signals and information across spatially separate markets (Goletti et al., 1995, Enke, 1951, cited by Rapsomanikis et al., 2003). The basis is that linkages are often interpreted as providing insights into the market's infrastructure efficiency and the transaction costs (infrastructural issues such as road systems, market development, transportation, etc).

However, because of the rapid development and growth that Brazil is experiencing, cointegration analysis is not enough. An increase in investments to improve roads would reduce the cost of transportation (IPEA, 2010) and could change the relationship with the national market. Equally important are the enhancement of ports, which could strengthen relations with Argentina and Uruguay (IPEA, 2010a). Finally, the NE as well as the rest of Brazil, has gone through a fast increase in percapita income which has effects on consumption habits, decreasing, for example, the dependence on rice. This makes it essential to define which variables affect integration, in order to anticipate changes in spatial integration.

In an effort to establish the integration structure of the NE rice markets, the main objective of this research is to determine the grade of integration of the NE with both national and international markets and examine which variables alter it. Spatial integration is calculated between each market pair. These can be measured through different methodologies. We choose the most common and recommended, the cointegration approach using the Vector Error Correction Model (VECM) (Johansen, 1995). Cointegration analysis gives a measure of the integration relationship as a result, thus, the markets with a stronger effect on NE. To account for changes of the economy during the period of investigation, the presence of structural breaks is allowed for. Using OLS and Logit regressions, the influence of three possible variables are evaluated: the access to a main port, the geographical distance between markets and the gross domestic product (GDP).

The main contribution of this research is twofold. First, the analysis of integration of Brazilian rice markets, of which there are presently few investigations and none which focus solely on the NE. Second, a next step is incorporated in order to explain the variables which influence integration. The latter is especially important for obtaining the expected outcome of government policy measurements.

Section 6.2 provides an overview of the NE's rice market. Section 6.3 gives central details about the characteristics of Brazilian and international markets which have an effect on the integration. Section 6.4 describes the estimation methods. Data characteristics are presented in Section 6.5, results are given in Section 6.6 and Section 6.7 concludes with final remarks. 


\subsection{The Economic Situation of the Northeastern Region of Brazil}

The Northeastern region of Brazil has historically been the poorest region in the country, with a percapita GDP of only one third of that of the Southeast, the most developed region. More than 9.6 million people live on a wage of 42 dollars per month, which is below the extreme poverty line given by the Federal Government. At the state level the situation is clearer, for example São Paulo (in SE) has a GDP per-capita 4.5 times that of Piauí (in NE) (IBGE, 2011). In addition, the Hunger Map II of Brazil shows that the states at the top of the poverty ranking are in the NE. Maranhão, Alagoas and Piauí are the extreme cases with more than $60 \%$ of their populations under the line of poverty (FGV, 2004).

The recurrent droughts in the NE are closely related to this situation, provoking high volatility in the agricultural sector and subsequently the rest of the economy (Somik \& Zmarak , 2003). Duarte (2001) affirms that the adverse climate conditions of these semi-arid zones are unfavorable for agricultural productivity, where the poorest people are also the most affected.

In this region, rice is a main product of consumption. The purchase of rice is a central household expense among those with less income (Table 6.1). In the NE rice represents $12.5 \%$ of the expenses of the lowest paid persons. Moreover, rice is the most important source of calories in this part of Brazil. For instance, in the poorest states of Maranhão and Piauí, rice contributes to more than $30 \%$ of the caloric consumption, making the rice market a central topic in light of food security (Table 6.2).

Table 6. 1

Relative Participation of Rice in the Yearly Household Per-Capita Food Expenses by Income and Region

\begin{tabular}{|c|c|c|c|c|c|c|c|}
\hline & \multirow[b]{2}{*}{ Total } & \multicolumn{6}{|c|}{ Classification of Families by Income $(\mathrm{R} \$)$} \\
\hline & & $\begin{array}{c}\text { less or equal } \\
\text { to } 830\end{array}$ & $\begin{array}{c}\text { more than } \\
830 \text { to } 1245\end{array}$ & $\begin{array}{c}\text { more than } \\
1245 \text { to } 2490 \\
\end{array}$ & $\begin{array}{c}\text { more than } \\
2490 \text { to } 4150\end{array}$ & $\begin{array}{c}\text { more than } \\
4150 \text { to } 6225\end{array}$ & $\begin{array}{c}\text { more than } \\
6225 \\
\end{array}$ \\
\hline Northeast & 9.40 & 12.51 & 9.93 & 8.05 & 7.22 & 9.92 & 4.32 \\
\hline North & 8.78 & 10.71 & 9.40 & 9.11 & 6.50 & 6.93 & 6.41 \\
\hline Middle West & 12.37 & 18.35 & 15.49 & 13.81 & 9.99 & 9.26 & 6.74 \\
\hline South & 5.79 & 9.41 & 8.58 & 6.37 & 4.95 & 4.20 & 3.05 \\
\hline Southeast & 8.19 & 12.43 & 11.13 & 9.47 & 7.86 & 6.37 & 3.71 \\
\hline Brazil & 8.41 & 12.30 & 10.47 & 8.80 & 7.21 & 6.58 & 4.05 \\
\hline
\end{tabular}

Source: Author's Elaboration. Data IBGE, 2010

\section{Table 6. 2}

Relative Participation of Total Caloric Consumption Determined by Household Food Acquisition (2008-2009): Rice and the Most Important Food Groups

\begin{tabular}{lccccccccccc}
\hline Types of expenditure & Maranhão & Piauí & Ceará & Paraíba & Bahia & Pernambuco & Alagoas Sergipe & $\begin{array}{c}\text { Rio Grande } \\
\text { do Norte }\end{array}$ & $\begin{array}{c}\text { Average } \\
\text { Northeast }\end{array}$ \\
\hline Cereals and Grains & 50.1 & 43.3 & 37.4 & 38.1 & 31.1 & 37.5 & 36.7 & 33.1 & 33.8 & $\mathbf{3 7 . 9}$ \\
$\quad$ Husked rice & 39.3 & 30.8 & 19.3 & 12.7 & 10.8 & 8.9 & 11.9 & 8.7 & 8.5 & $\mathbf{1 6 . 8}$ \\
Meat & 11.7 & 12.2 & 10.7 & 11.1 & 11.7 & 12.6 & 16.5 & 15.3 & 13.1 & $\mathbf{1 2 . 8}$ \\
Vegetable oils and fats & 9.2 & 10.6 & 10.1 & 10.7 & 10.8 & 10.6 & 10.7 & 9.3 & 9.5 & $\mathbf{1 0 . 2}$ \\
Sugar and Soft drinks & 8.8 & 11.5 & 15.4 & 15.1 & 13.2 & 13.0 & 13.0 & 12.0 & 14.5 & $\mathbf{1 2 . 9}$ \\
\hline
\end{tabular}

Source: Author's Elaboration. Data IBGE, 2010

Regarding production, Maranhão and Piauí are the most important states, which together are responsible for $83 \%$ of the region's production. They are the third and fifth biggest producing states in Brazil. In addition, farms in this region are mostly small with an area of 2 ha or less (78\% Maranhão 
and $87 \%$ Piauí). However, production is concentrated on the relatively few larger farms. For instance, in Maranhão while $11.9 \%$ of production is carried out on small farms, $48.5 \%$ of rice is produced by medium sized farms (between 20 and 100 ha), which represent just $3.5 \%$ of the total number of farms (IBGE, 2006).

\subsection{Spatial Price Transmission and its Relevance to the NE}

On the basis of the above described, it can be affirmed that rice is of central importance for the population of the NE. As mentioned in the introduction, our focus is on the integration of the NE with other markets, meaning its spatial price transmission (SPT). The international food price increases of 2007-2008 highlighted the relevance of the STP for the NE. The world price of Thai rice was $\$ 362$ per ton in December of 2007 and almost tripled to around $\$ 1000$ per ton at the end of April 2008 (IRRI, 2008). This increment translated into price increases in many developing countries and had, in those populations with high consumptions of rice, a tremendous impact on the real incomes of the poor households. However, the intensity was not the same in each case; for example Thailand saw rises $60 \%$ above the international level, the Philippines around $20 \%$ to $30 \%$, while the impact in China was almost zero (Keats et al., 2010). The main reason for was the dissimilarity of characteristics among countries, such as access to information and transport costs; for example, Benson et al. (2008) mention the case of Uganda which was isolated from the global market, and thus experienced no effect from the rising international prices. They also mention that the lack of government actions available to protect the consumer from the increment of international prices was not important since it was unnecessary in Uganda. Therefore, if a region like the NE is not prepared to face international prices movements, but is strongly connected to them, its food security can become tenuous. However, if a connection doesn't exist it would be unnecessary to apply a costly measurement. The same is true regarding national markets; when strong connection exists between the NE and the South, excessive rains in the South should mean special measurements to protect the poor consumers.

Before starting with the price transmission analysis, an overview of the trade markets of the NE region and the characteristics associated with the trade relations are presented in the following sub-sections.

\section{a. National Markets}

The biggest producer of rice in Brazil is the state of Rio Grande do Sul, where in 2005 the harvest was around $46 \%$ of national production. In this state production is characterized by the large size of farms (around 200 ha) and the high level of technology used. In addition, the other two states in the southern region, Santa Catarina and Parána, together with the MW state of Mato Grosso are significant producers as well (MAPA, 2005).

Río Grande do Sul is also the principal supplier of the biggest consumer centers located in the NE and the SE of the country. São Paulo (in SE) contains a principal core of consumers with an enormous influence on the formation of prices (dos Santos et al., 2005). 
Trade between the states is an unclear issue as there is no registry of products traded, making it impossible to establish the amount of rice marketed between states. However, according to information supplied by Regina Santos, a rice market analyst (CONAB, 2011), there is a small production surplus in the North and MW, being $1 \%$ and $18 \%$ of total production of each region, while the surplus of the SE is $78 \%$ of its total production. She also mentions how the South supplies the deficit of the SE and the NE; in these two regions production is around 4.15 times less than consumption.

Centering the attention to the NE, Perobelli and Haddad (2006) analyze the presence of global and local spatial autocorrelation in the distribution of trade and conclude that most of the states have low interregional trade. More specifically, the degree of dependence of the NE's states towards the South and SE, principally the state of São Paulo, is higher than within the region (Perobelli \& Haddad, 2003; Perobelli et al., 2006).

In addition, the NE has a competitive disadvantage concerning the production of rice. The productivity of the two biggest producers, Maranhão and Piauí, is around 2.13 ton/ha which is three times lower than in the Southern region of Brazil (MAPA, 2005). This can be explained by the fact that at the NE region is the driest and most prone to drought areas of the country. The situation is exacerbated by the prevalence of upland rice which is extremely sensitive to rainfall patterns and is historically known by its lower grain quality (YOU, 2008). Even so, Pernambuco and Alagoas (in the NE) perform well in comparison to the rest of Brazil, average yields of 4.65 and 5.90 ton/ha (MAPA, 2005), however they produce a quantity which is not enough to supply the domestic demand.

It is also important to look at previous results of price transmission in order to make comparisons at later stages in the analysis. From the literature review, only one investigation has been found at the state-level which deals with Brazil's rice market. Gonzales and Helfand (2001), through the use of multivariate system, affirm that rice is traded extensively within the country and underscore the centrality of the SE, specifically São Paulo, in the adjustment process and the long-run equilibrium. They found that the distance between São Pablo and the other states has an effect on the long run equilibrium and the speed of adjustment. Using a ratio of state consumption and production, they confirm that the NE, with the exception of Maranhão, is clearly a net importing region as steady inflows of rice from Rio Grande do Sul are always necessary. In addition, they found that the adjustment to the equilibrium between Maranhão and São Paulo is by far the slowest.

We expect to find strong integration between the states of the NE and the principal actors São Pablo and Rio Grande do Sul. We also expect to observe significant relationships among the NE and the remaining SE states, Santa Catarina and Parána, although a less strong one. Nevertheless, in the case of Maranhão and Piauí, although they are self-sufficient regarding the consumption of rice, meaning no dependency on other markets, the lower quality of the production causes the importation of better quality rice, which could strengthen the relationship. Therefore, even if they are important consumers 
and producers it is not possible to develop clear expectations, this is specially explained by the lack of specific information regarding domestic trading activities in Brazil.

\section{b. International Markets}

Worldwide Brazil is one of the ten principal producers, exporters and importers of rice; the percentage of imports in relation to national production is much higher in Brazil than for any other country, around 6.4\% (Wander, 2006). In this context, Argentina and Uruguay are the two principal suppliers. For instance, during the period of 1995-2005, the average share of the total import of rice coming from these countries was $89 \%$. All through this period Uruguay's exports were higher than those of Argentina, the ratio between the imports of Uruguay versus Argentina was 2.74 in 2001, 3.17 in 2002 and in 20032.94 (MAPA, 2005).

The cost of production in Uruguay and Argentina is far below that of Brazil and the productivity is considerably higher (da Silva \& Dalla, 2009). This trend has three principal explanations. First, there is no uniform tax system within the MERCOSUR; in Brazil the tax burden for rice is around 40\%, while in Argentina it is $16 \%$ and in Uruguay just 14\%. The second is the cost of renting land, which in Brazil is between two to three times more expensive. However, the biggest difference is in the interest rates. Although producers in Brazil have a wide array of possibilities with which to obtain financial support, the base rate is two times of Argentina's and six times of Uruguay's (Marion \& Eich, 2008).

There are substantial differences among the rice markets of Uruguay and Argentina. First, these two markets differ concerning how prices are defined. The price system in Uruguay is called the "Precio Convenio" (Price Agreement), in which the "Asociacion Cultivadores de Arroz" (Rice Growers Association), on behalf of its producers, negotiates and agrees with the industry, specialized in the industrialization and search of markets, in order to find a suitable price (the average price of exportation minus transaction costs) which is paid to all producers (ACA, 2011). On the contrary, in Argentina there is not a fixed price or government intervention. Second, the dependency of the external markets to locate production is higher for Uruguay, because the consumption of rice inside the country is small and the producers of rice are high specialized (da Silva \& Dalla, 2009).

Concerning price transmission, Dutoit et al. (2010) found that Brazil's rice market shows a strong relationship with the FOB prices of Argentina and Uruguay. Moreover, the results show a stronger relationship in the reselling markets than in the producer markets.

With respect to the NE, once again Uruguay exports a higher quantity of rice than Argentina; however, the tendency has been changing, as shown in Figure 6.1. Additionally, the access of the product is mostly through Pernambuco, Ceará and to a lesser extent Bahia (MDIC, 2011). First of all, this is because these are the most populated states in the NE; for instance, Bahia, the largest one, has almost the same population as São Paulo.

Furthermore, Figure 6.1 shows that the principal route rice entry is Maritime, which is an issue of port quality. The port of Recife, located in Pernambuco, is one of the oldest and most essential ports of 
Brazil. This port has some of the best infrastructure in the NE, is one of the biggest ports of the region and has witnessed strong modernization. Additionally, there is another central port in Pernambuco, Suape, which in 2009 had the highest amount of unloaded tons in the NE (ANTAQ, 2009). Regarding Ceará, the port of Mucuripe is located in its capital, Fortaleza, where the cargo handled has significantly increased in recent years, including a notable increment in rice (Diário do Nordeste, 2009, 2010, 2011).

Figure 6. 1

North East Imports Coming from Argentina and Uruguay According to the Route of Access (Thousand US\$ FOB)

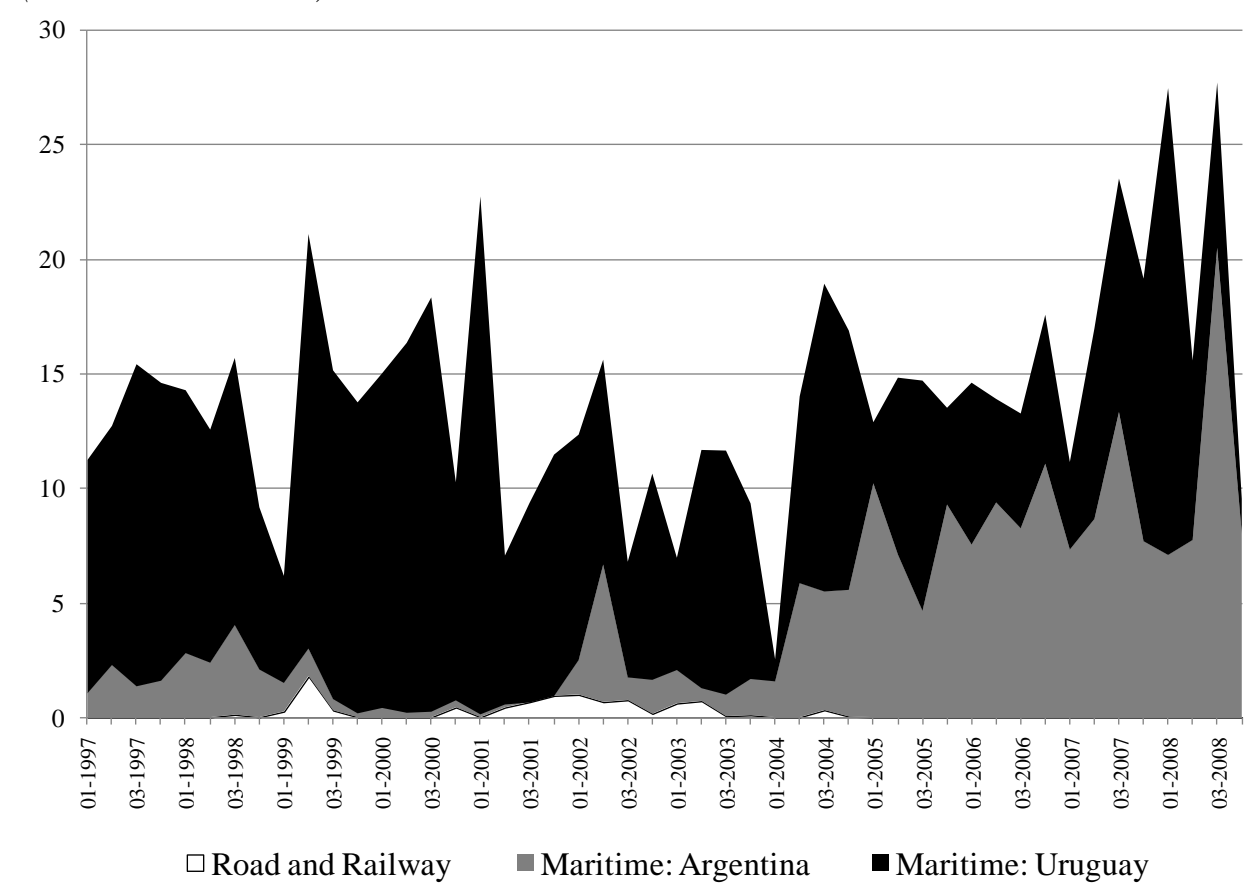

Code Description from 1006.10.10 to 1006.30.29

Source: Author's Elaboration. Data MDIC (2011).

Based on the above description, we anticipate a relationship between international prices and the prices of Pernambuco, Bahia and Ceará, more so than with the rest of the states. Moreover, the states closer to these are also expected to be related but to a lesser extent. In addition, in view of the fact that Uruguay is a bigger extorter compared to Argentina, it is expected that more cointegration with Uruguay will be found. However, the fact that Uruguay is more dependent on Brazil could result in Brazilian markets having an impact on Uruguay's and not the opposite.

\section{c. Economic Reforms and other Relevant Events between 1990 and 2006}

As was mentioned in Chapter 5, the economic reforms which took place in Brazil during the 1990's have had a decisive role in defining the current agricultural conditions. In this regard, the most relevant events were: the adjustments of the minimum price policy, the beginning of the "Real Plan" in 1994 which was followed by the agricultural crisis of 1995, and perhaps the most important event which took place in January of 1999 when the currency was allowed to float freely and depreciated by $50 \%$. 
Concerning those events related to the relationship among the Brazilian, Argentinean and Uruguayan rice markets, it is first worthy to mention MERCOSUR. The agreement was signed in 1991 eliminating internal tariffs and establishing a common external tariff (CET), thus provoking an increase in the amount of rice from Argentina and Uruguay. However, the variable leading the relations between these three rice markets has been the exchange rate. In the beginning of the 1990's the principal problem of the Brazilian economy was inflation, which weakened the Brazilian currency and the competitiveness of Argentinean and Uruguayan rice. The "Plan Real" changed this situation by fixing the rate of exchange in parity with the US dollar. However, the significant fracture in the currency policy of 1999 affected imports in a negative way until the crop failure of 2002-2003 in Rio Grande do Sul. The growth of imports in 2002 was supported by a new appreciation of the Real (Brazilian currency) since 2003 (Marion \& Eich, 2008; da Silva \& Dalla, 2009). In the specific case of Argentina, the political crisis of 2001-2002 leads, as a consequence, to the devaluation of the Argentine peso and provoked an increase in export competitiveness (da Silva \& Dalla, 2009).

Bearing these events in mind, the cointegration measures are once again expected to vary during the analysis period. This is due to the effect of the economic changes on both consumers and producers behavior. For instance, in the case of the consumers, the opportunity cost of buying products from an international market compared to the domestic market is modified through the variation of the exchange rates. In addition, the increment of the real per-capita income, like the one created to the control of inflation in 1994, decreases the demand of inferior goods in favor of normal goods. When considering the poorest states especially and considering rice as an inferior good, it can be said that this statement is true regarding rice consumption in Brazil. In the case of producers, adjustments in the market conditions, such as price support and credit options, favor some producers and damage others, thus changing the states' market share. Moreover, a crop failure, like the one in 2002, forces the net rice-importers to look for new export partners and thus establish new mechanisms which facilitate future commerce.

In spite of the possibility of roughly indentifying the timing of the most significant events, the characteristics associated with the rice market of each state of Brazil point to the fact that the effect on cointegration relationships will not be the same or in the same time for all markets. Some examples can be mentioned; firstly, during this period the price support policy experienced a modernization of instruments which caused, as an effect, the producers of the most developed markets, such as Rio Grande do Sul and Santa Catarina, to apply more sophisticated instruments than the less developed markets, to assure less volatile rice price and stable income (de Oliviera et al., 2008). For the developed markets, this could delay the necessary adjustments in response to the economic events. Secondly, the small family producers have special lines of credit, and more recent support due to the "Programa de Garantia Preços para a Agricultura Familiar" (Price Guarantee Program for Family Agriculture) as well. Consequently, the adjustment will take place at a different rate in states with a lower share of family production. Regarding consumers, various food security programs have been implemented. Although these programs were reduced between $1995-1999$, they had a fresh impulse 
and an improvement with the creation of the plan "Fome Zero" (Zero Hunger) started in 2003 (Costa $\&$ Pasqual, 2006). These programs are aimed at increasing the purchasing power of the principal consumers of rice, the poor people, whom are geographically concentrated especially in the NE, as was mentioned before. Therefore, the impact of these policies was not the same for all states. In addition, an important part of the food security programs is handled by the state government, thus causing variations in the applications and effects of the policies. For example, the state of Paraiba bought products to donate to schools and hospitals from local family producers only (Governo Da Paraiba, 2011).

Based on the strong economic and policy changes which affected the agricultural sector of Brazil, price transmission relationships are expected to present significant structural breaks and these breaks will not be of the same range and at the same time for all markets pairs.

\section{d. Possible Determinants of the Integration Measures in Brazil}

In Section 3 of the $5^{\text {th }}$ Chapter, the variables which could affect integration relationship were explained in detail. In this sub-section the facts considered relevant for this research are highlighted. Additionally, extra information concerning the relevance of each variable in the case of the NE is added.

\section{Gross Domestic Product (GDP)}

Helpman (1987) found that one powerful variable which can predict the commerce between countries is size, where two countries with similar size have a higher trade volume. This is also one of the bases of one of the most successful empirical tested theories: the gravity model (Tinbergen, 1962). The model was developed to explain the size of the trade between two countries, accounting for variables related to potential supply and those related to potential demand. The GDP of the exporter represents supply and the GDP of the importer demand, where trade positively depends on the GDPs of two countries (Frankel et.al, 1995, Paz \& Arinos de Mello, 2003). de Sá Porto (2002), by applying the gravity model equation, found that GDP is a significant variable to explain the amount of trade between Brazilian regions and international markets. Even if the gravity model is based on trade flow, we can expect that the size of the market is also a variable which has an effect on integration.

In Brazil GDP has been growing at a considerable rate, around $11.8 \%$ per year in nominal terms. The same is true for the NE which witnessed a growth of $13.9 \%$ in 2005 and 14.29\% in 2008. Maranhão, for instance, is the state with the biggest increase in GDP, 17.8\% in 2005; and Alagoas, the lowest with a growth of $9.69 \%$ in the same year (IBGE, 2011).

\section{Distance}

Another variable mentioned in the gravity model is the distance between markets, which is expected to have a negative effect on trade (Tinbergen, 1962). This variable is viewed as a proxy for other trading obstacles, such as transportation costs (Paz \& Arinos de Mello, 2003). This particularly applies to the case of Brazil, one of the largest countries in the world with an active commerce among its states. For 
example, farmers in the Cerrano zone (in the MW) need to transport their products more than 1000 $\mathrm{km}$, while they also need to import essential inputs to be productive (Flaskerund, 2003). Moreover, around $60 \%$ of the products are transported by road, an amount much higher than in the USA $(26 \%)$ or China (8\%) (ANTT, 2011).

The Brazilian government has made recent efforts to improve the quality of roads and thus to decrease transportation duration and its' costs. In the last 10 years there has been a huge private and a moderate public increase in investments for improving roads. At the same time, the Federal Constitution has changed, assigning part of the taxes resulting from the commercialization of oil to the improvement of transportation infrastructure. As a consequence, the total amount of investment in roads grew in real terms, around 2465\% between 1999 and 2008 (IPEA, 2010). Moreover, the recently begun "Programade Aceleração do Crescimento" (Growth Acceleration Program), or PAC, includes an important budget target for investments in roads, from which the NE is receives around 18\% (IPEA, 2010). However, research conducted by the IPEA (2010) showed the necessity of investing around 90.3 billion dollars to improve the actual status of roads and another 24 billon to build new ones. They also established that the NE is the country's region which requires the highest amount of investments in the maintenance of roads and second in the construction of new state roads. It is also worth mentioning that transport costs in the NE were found to be $33.1 \%$ higher as a consequence of the roads' quality conditions.

As was mentioned in Chapter 5, recent research has pointed out that distance affects market integration (Sanogo, 2008; Goletti et al. 1995; Escobal \& Vásquez, 2008; Alemu \& Biacuana, 2006). The argument is similar to that of the gravity model; distance is important since it raises trade costs, particularly transport costs and storage costs, all of which lower the profitability of trade. In this regard, Limão and Venables (2001) found elasticities of transport costs with respect to distance between 0.2 and 0.3 . The narrow link between transaction costs and distance is a reason to expect a higher cointegration between closer markets. However, it must not be forgotten that the expected significant effect of distance on integration is also a reflection of other variables which have an effect on integration and which are more similar between closer markets than distant ones.

\section{Access to International Markets: Ports}

Following the argument exposed beforehand, it is expected that one market will have a stronger connection with a spatially closer market one. However, this is not always the case. For instance, Dutoit et al. (2010) found the maize market of Chile to be a little more connected with that of the USA rather than with Argentina's. One possible explanation is the transport costs. Limão and Venables (2001) found that overland distance is around 7 times more expensive than sea distance, and being landlocked increases transport costs by approximately 50\%. In view of the advantage of using the sea as a cheaper means of transportation, not only the distance between two markets, but also the facility to access a port, can affect the behavior of prices. Tun-Hsiang et al. (2006) point out that shocks in 
transportation rates (barge, rail, and ocean) explain a considerable proportion of the variation in corn prices $(42-64 \%)$.

In 2007 Brazil's ports were responsible for the movement of $76.7 \%$ of its international trade. In total, there are around 30 main ports distributed along the coast and the principal rivers of Brazil. The three largest ones are responsible for $57 \%$ of total loading and unloading. One of them, Rio Grande, which is located in the principal producing state, is essential for the commerce of rice (Ministerio dos Transportes, 2010). However, the current port system has many problems, which are principally concentrated in the necessity of land access, construction, expansion and the renovation of the port areas (IPEA, 2010a). All of these factors resulted in Brazil being placed in position 123 regarding the quality of ports world-wide (FDC \& FEM, 2009). In the case of the NE, there is a key problem of inefficiency of many of the ports which is a disincentive and a hurdle for imports. The ports of Itaquí and Pecem are the more needing of infrastructure improvements, while Suape needs an urgent investment in dredging. However, as mentioned in Chapter 5, port infrastructure has experienced a strong development. For instance, there has been a significant increment in private participation which resulted in an increment of $861 \%$ of total investments in ports between 1999 and 2008 (IPEA, 2010a).

The above mentioned, in conjunction with the lower production costs in Argentina and Uruguay and the fact that the NE is a net importer of rice, leads us to expect that access to a main uploading port will have a significant impact on the integration relationship with the international markets. Moreover, remembering that the main producers of Brazil are coastal states and the core of consumption is close to the coast as well, it is also awaited that closeness to a large port will have an effect on the integration between national markets.

\subsection{Methodology}

Price transmission can be measured through a broad number of methodologies. The cointegration approach is chosen since this is a strong methodology which is widely applied. The investigation is divided into two parts; first the cointegration analysis is given and, secondly, the effect of the related variable is estimated using OLS and a probit regression.

Using the Vector Error Correction Model (VECM) (Johansen, 1995; Pfaff, 2006), cointegration is used to test the existence of non-spurious long run integration between each market pair. First, $P_{t}=\left(P_{t}^{y}, P_{t}^{x}\right)(t=1 \ldots \mathrm{T})$ is assumed to have a vector autoregression representation (VAR) of order $p$ :

$P_{t}=\Pi_{1} P_{t-1}+\cdots+\Pi_{\mathrm{p}} P_{t-p}+c+\phi D_{t}+\varepsilon_{t}$

Where $\Pi_{\tilde{i}}(\mathrm{i}=1, \ldots, \mathrm{p})$ are the $(2 \times 2)$ coefficient matrices of the lagged endogenous variables, $c$ is a (2x1) vector of constants and $D_{t}$ is a vector of seasonal dummy variables. In our case, the optimal number of lags $p$ corresponds to the maximum among AIC, HQ, SC and the FPE criterion. From equation (6.1) the next VECM can be delineated:

$\Delta P_{t}=\Pi P_{t-1}+\Gamma_{1} \Delta P_{t-1}+\ldots+\Gamma_{p-1} \Delta P_{t-p+1}+\mu+\phi D_{t}+\varepsilon_{t}$ 
$\Gamma_{i}=-\left(\Pi_{i+1}+\cdots+\Pi_{p}\right)$ for $\mathrm{i}=1, \ldots, \mathrm{p}-1$

$\Pi=-\left(I-\Pi_{1}+\cdots+\Pi_{p}\right)$.

If $P_{t}^{y}$ and $P_{t}^{x}$ are $\mathrm{I}(1)$ variables, $\Delta P_{t-i}(\mathrm{i}=1, \ldots, \mathrm{p}+1)$ are stationary or $\mathrm{I}(0)$, given that $\varepsilon_{t}$ is assumed to be i.i.d. $\varepsilon \sim \mathrm{N}(0, \theta), \Pi P_{t-1}$ must be $\mathrm{I}(0)$ too, otherwise the VECM will not be balanced. Taking that into consideration, if the coefficient matrix $\Pi$ does have a full rank ( $r$ ) (in our case if $r=1$ ), we can represent $\Pi$ like the combination of two full rank matrices $\alpha$ and $\beta^{s}$ such that $\beta^{\prime} P_{t-1}$ is stationary. The $r$ lineal independent columns of $\beta$ are the cointegration vector and represent the long run relationship between the individual series of $P_{t}$. The elements of $\alpha$ determine the speed of adjustment to the long run equilibrium. Because $P_{t}$ is a vector of two variables, $\alpha$ is a $2 \times 1$ matrix, where the first row corresponds to the percentage adjustment of $P_{t}^{y}$ in replay to the deviation of the long run equilibrium $\left(\alpha_{\mathrm{y}}\right)$, and the second row the $P_{t}^{x}$ adjustment $\left(\alpha_{\mathrm{x}}\right)$. Johansen (1988), Johansen and Juselius (1990) and Johansen (1995) have developed maximum likelihood estimators of these cointegration vectors.

However, in the previous section was mentioned how Brazil has experienced a series of structural changes which are different in magnitude and timing among the relationships. In order to take that into consideration and to avoid biased results, the procedure suggested by Lütkepohl, Saikkonen and Trankler (2004) is applied. The idea is to estimate and remove the deterministic part, including the shift provoked by the structural break, in a first step, and then to apply the VECM presented above to the adjusted series. Here $P_{t}$ is assumed to be generated by a process such as:

$P_{t}=\mu+\delta d_{t}^{\tau}+x_{t}$

Where $\mu$ and $\delta$ are unknown parameter vectors and $d_{t}^{\tau}$ is a step dummy variable representing a shift in period $\tau$, then $d_{t}^{\tau}=0$ for $t \geq \tau$. The term $x_{t}$ is an unobservable error process that is assumed to have a $\operatorname{VAR}(p)$ representation:

$x_{t}=\mathrm{A}_{1} x_{t-1}++\mathrm{A}_{\mathrm{p}} x_{t-p}+\epsilon_{t}$

where $A_{j}$ are (nxn) coefficient matrices. On the basis of equations (6.3) and (6.4), with the VECM methodology it is possible to transform equation (6.3) to (see for e.g. Lütkepohl \& Saikkonen, 2000; Lütkepohl et al., 2004):

$$
P_{t}=v+\delta_{1} d_{t}^{\tau}+A_{1} P_{t-1}++\mathrm{A}_{\mathrm{p}} P_{t-p}+\epsilon_{t}
$$

The period of shifting is estimated as the one which minimizes the square of $\epsilon_{t}$. The first step of this approach finishes here with the estimation of the deterministic part based on the results of equation (6.5). In the second step, in order to remove the deterministic part, the VECM is applied to $\hat{x}_{t}$ where: 
$\hat{x}_{t}=P_{t}-\hat{\mu}-\hat{\delta} d_{t}^{\hat{\mathrm{t}}}$

$\Delta \hat{x}_{t}=\Pi \hat{x}_{t-1}+\Gamma_{1} \Delta \hat{x}_{t-1}++\Gamma_{p-1} \Delta \hat{x}_{t-p+1}+\mu+\phi D_{t}+\varepsilon_{t}$

The estimator of the matrix $\alpha$, the speed in which the prices revert back to the equilibrium, and $\beta$, the long run relationship between each pair of prices, is realized using the VECM of equation (6.7). $P_{t}^{y}$ and $P_{t}^{x}$ are included in the analysis in logarithmic form; this allows for the identification of $\beta$ as the elasticity of cointegration. In addition, to ensure that the system was not misspecified, the Lagrange Multiplier test for serial correlation, the Garch test for heteroskeedasticity and the Jaque Bera test for normality are estimated to equation (6.7). Finally, in order to account for care of short run structures related to the number of lags, the impulse response function is applied to the VAR version of the equation (6.7) (Lütkepohl, 2006). This function estimates the effect of a unitary increment in the actual period of one of the two prices over the futures values of the price itself and the other price. In the first periods the prices will change in order to reach the new equilibrium, and then, once the equilibrium is achieved, the changes tend to 0 .

The methodology described above is carried out between each rice market pair included. The multivariate analysis is not incorporated since carrying out the analyses with many states turned out to be computationally unmanageable, particularly due to the low degrees of freedom resulting from the inclusion of seasonal dummies. Moreover, it is difficult to estimate unknown breaks, related to each market pair, using the multivariate analysis. At this point there are three indicators for each market pair; first if the prices are cointegrated, second the elasticity of cointegration $(\beta)$ and finally the speed of adjustment $(\alpha)$. Moreover, we can split the cointegrated relationships into two groups and two subgroups:

I. Between two national markets, which is further divided into:

a. relationships which include at least one NE market and,

b. relationships without a NE market.

II. Between a national market and an international market:

a. relationships which include one NE market,

b. relationships which include a Brazilian market apart from the NE.

Although the main interest of this research is both categories of $\mathbf{a}$, the categories of $\mathbf{b}$ are central in the next part of the analysis since the number of relationships which include the NE are not enough to obtain strong results in the OLS and probit analysis.

As said before, only knowing the grade of cointegration and its structural changes does not enable us to produce estimations of price transmission future behavior since there are variables which affect integration and have been evolving. Hence the effect of these variables also needs to be analyzed. With that in main, the second part of the methodology is split into two, starting with the analysis of the effect of the influence variables on integration of the national markets and followed by the effect on 
integration with the international markets. Regarding the first, for the reason that the number of observations in category I.a. is not enough to apply the analysis, in this step all of category $\mathbf{I}$ is included. Next, using simple OLS methodology the following equations are estimated:

$$
\begin{aligned}
& \beta_{i}=\omega_{1} \text { Port }_{i}+\omega_{2} \text { Distance }_{i}+\omega_{3} \mathrm{GDP}_{\mathrm{i}}^{\mathrm{X}}+\omega_{4} G D P_{\mathrm{i}}^{\mathrm{Y}} \\
& \alpha_{i}=\theta_{1} \text { Port }_{i}+\theta_{2} \text { Distance }_{i}+\theta_{3} \text { GDP }_{\mathrm{i}}^{\mathrm{X}}+\theta_{4} G D P_{\mathrm{i}}^{\mathrm{Y}}
\end{aligned}
$$

where $\mathrm{i}=(1, \ldots, \mathrm{k})$ in which $\mathrm{k}$ is the number of cointegrated relationships. The dependent variable in $(6.3)$ is the elasticity of cointegration and in (6.4) the net speed of adjustment (absolute value of $\left(\alpha_{y^{-}}-\alpha_{x}\right)$ ); since the net speed includes both adjustments ( the one of $P_{t}^{y}$ and the one of $P_{t}^{x}$ ) it is a better indicator of the velocity in which the long run equilibrium is reached. Table 6.3 shows the description of the independent variables.

Finally, category II corresponds to the integration with the international markets of Argentina and Uruguay. However, since there are only a small number of cointegration relationships between Brazilian and international prices, a detailed analysis of the behavior of $\beta$ and $\alpha$ is not possible. Nevertheless, identifying the effect of the independent variables on the absence or presence of cointegration is possible. Hence, the following probit model is applied:

$$
\text { coint }_{i}=\Theta_{1} \text { Port }_{i}+\Theta_{2} \text { Distance }_{i}+\Theta_{3} \text { GDP }_{i}^{\text {National }}+\Theta_{4} \text { Inter. Market } t_{i}
$$

where coint $=0$ when there is no cointegration between the two markets and coint=1 when there is cointegration. The independent variables are the same as displayed in Table 6.3.

All of the explained econometric analyses were carried out using the free access program R 2.12.1.

\begin{tabular}{|c|c|c|c|}
\hline Variables & Description & Measure & Source \\
\hline Port & $\begin{array}{l}\text { At least one of the markets in the relationship is located in a } \\
\text { state which has minimum one port which is included in the list } \\
\text { of the } 10 \text { highest unloading amount ports. The ports without } \\
\text { capacity to store grain are excluded. }\end{array}$ & $\begin{array}{l}\text { not }=0 \\
\text { yes }=1\end{array}$ & $\begin{array}{l}\text { Agência } \\
\text { Nacional de } \\
\text { Transportes } \\
\text { Aquaviários }\end{array}$ \\
\hline Distance & $\begin{array}{l}\text { Distance between the two markets. } \\
\text { - In the case of Argentina this corresponds to the distance } \\
\text { between the Brazilian market and the state of Entre Ríos. } \\
\text { The latter is Argentina's most important rice producer. } \\
\text { - In the other case, Uruguay, most of the production is made } \\
\text { along the Brazilian's border; therefore, the distance to } \\
\text { Jaguarão, in the border of Brazil, is used. }\end{array}$ & Hours & Google maps \\
\hline GDP & $\begin{array}{l}2004 \text { Gross Domestic Product of the market } \mathrm{X} \text { and } \mathrm{Y} \text {. } \\
\text { In the analysis of the integration with the international } \\
\text { markets, GDP corresponds to the Brazilian markets. }\end{array}$ & $\begin{array}{l}\text { current prices } \\
\text { (billon of } \$ \mathrm{R} \text { ) }\end{array}$ & IBGE (2011) \\
\hline $\begin{array}{l}\text { International } \\
\text { Market }\end{array}$ & International price included in the relationship. & $\begin{array}{c}\text { Uruguay }=1 \\
\text { Argentina }=0\end{array}$ & \\
\hline
\end{tabular}

Table 6. 3

Independent Variables 


\subsection{Data Base}

Brazilian producer prices were provided by the Economic Commission for Latin America and the Caribbean of Chile (ECLAC) and are from the ECLAC's office in Brazil. The time span of the monthly data starts in January 1993 and ends in January 2006 for the majority of the series (Annex 6.1, Table 6.8). The market exchange rate average was obtained from the International Financial Statistic (IFS) and was used to convert the prices into US dollars per kilo.

The international series corresponds to monthly FOB prices in US dollars per ton (Annex 6.1, Figure 6.3). Argentinean prices were obtained by consulting the Ministry of Agriculture of Argentina (SAGPyA) and Uruguayan prices were made available by the United States Department of Agriculture (USDA).

The type of rice considered is paddy rice, that is, rice that has been cut from the plant only, with the husk, i.e, without any transformation. The variables are used in their logarithmic form. Missing values represent $2 \%$ of the data base. They were filled in using an imputation algorithm proposed by King et al. (2001) and the corresponding R-package AMELIA II, developed by Honaker et al. (2009). 1000 imputations for each missing value were performed and its most likely values were estimated using Parzen's (1962) nonparametric mode estimator.

\subsection{Analysis of Results}

Before beginning the cointegration analysis, it is necessary to indentify the integration order of the series. The same procedure discussed in Chapter 5 (Section 6) is carried out (details Annex 5.2, Table 5.8). There are 27 prices; 26 are non-stationary and the first difference for each variable is $\mathrm{I}(0)$. Additionally, the two international prices are $\mathrm{I}(1)$ and the first difference is $\mathrm{I}(0)$.

First of all, the results show, as expected, an important concentration of break points in 1994, 1999 and 2002-2003 (Table 6.4). In 1994, the first concentration of breaks, the Plan Real started with its incentives to increase credit amounts as well as changes in the minimum price policy. The second break concentration is in 1999 when the currency was allowed to float. Finally, the last break concentration is in 2002 when there were crop failures in Rio Grande do Sul, together with the new appreciation of the Real in 2003. However, 2001 is also worth mentioning, as it marked the beginning of the political crisis in Argentina; in almost all of the cases this is the year in which the cointegration relationships with this country experienced structural breaks (Annex 6.2, Table 6.9). Regarding the aforementioned in Sub-section c of Section 6.3, as we expected, although most of the cases are concentrated around these main events, there are other cases in which the timing of the break is one or two years behind the main events (Annex 6.2, Table 6.9). 
Table 6. 4

Break Points

\begin{tabular}{|c|c|c|c|c|c|c|}
\hline \multirow[t]{2}{*}{ Years } & \multicolumn{3}{|c|}{$\begin{array}{l}\text { All relationships analyzed } \\
\quad \text { (category } \mathrm{I}_{\text {and }} \mathrm{II}^{+} \text {) }\end{array}$} & \multicolumn{3}{|c|}{$\begin{array}{l}\text { Relationships included at least a NE market } \\
\text { (category I.a and II. } \mathrm{a}^{\dagger} \text { ) }\end{array}$} \\
\hline & Cointegrated & Not cointegrated & Total & Cointegrated & Not cointegrated & Total \\
\hline 1994-1995 & 28 & 43 & 71 & 17 & 25 & 42 \\
\hline 1996-1997 & 7 & 18 & 25 & 3 & 8 & 11 \\
\hline 1998-1999 & 20 & 55 & 75 & 14 & 36 & $\mathbf{5 0}$ \\
\hline $2000-2001$ & 20 & 4 & 24 & 5 & 4 & 9 \\
\hline $2002-2003$ & 45 & 46 & 91 & 21 & 12 & 33 \\
\hline 2004-2005 & 7 & 24 & 31 & 3 & 18 & 21 \\
\hline Total & 127 & 190 & 317 & 63 & 103 & 166 \\
\hline
\end{tabular}

Methodology: Section 6.4

Source: Author's Elaboration

Starting with the analysis there is the case of the relationships between the NE markets and the remaining Brazilian markets, 125 relationships were analyzed where 50 are cointegrated. With only $40 \%$ of the relationships being cointegrated, it is possible to say that the NE is relatively isolated from the rest of Brazil. The elasticity and the speed of adjustment are represented as black points in Figure 6.2 (see Annex 6.2, Table 6.10 for details). The aim of Figure 6.2 is not to suggest a casual relation between the elasticity and speed of adjustment, but to give an idea about the level of integration in the $\mathrm{NE}$, taking both measures into consideration. In this regard, in the upper right corner of Figure 6.2 those relationships with high elasticities and high speeds of adjustment are located; in the lower left corner the relationships with the lowest values are located. The NE integration relationships are concentrated in the lower right corner with high elasticities but slow adjustments to the equilibrium. Nevertheless, the elasticity of cointegration is distributed over a wide range, in absolute value between 0.03 and 1.00 . 
Figure 6. 2

Northeast Cointegrated Relationships with Structural Breaks:

Elasticity of Cointegration $(\beta)$ and Speed of Adjustment $(\alpha)$

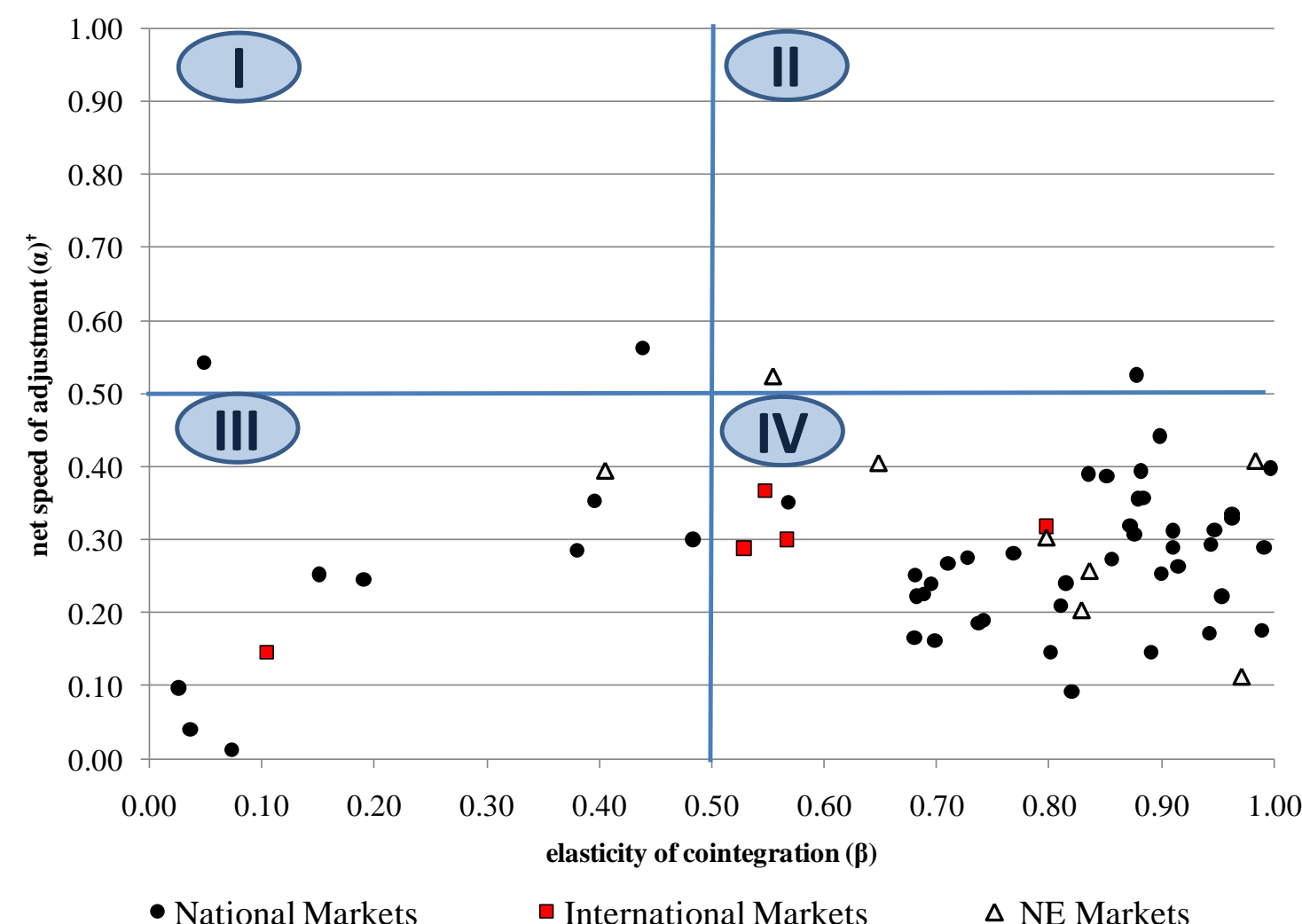

'Net speed of adjustment corresponds to the absolute value of ( $\alpha y-\alpha x)$

Source: Author's Elaboration.

The relationship Maranhão vrs Tocantis shows the weakest elasticity; this is Maranhão's only cointegrated relationship. This is in accordance with the fact that Maranhão is an important producer and it is self-sufficient. The same argument holds for explaining the low $\beta$ values related to Piauí, the other main NE producer, which are 0.07 with São Paulo, 0.19 with Goías and 0.38 with Minas Gerais. Pernambuco also stands out as the market with the highest number of cointegration relationships (13). This might be associated with the fact that the main NE ports for unloading rice are located here. Despite not having access to the quantity traded between the states, it is presumable that an important share of rice imports enters through these central ports.

The results also display that the major core of consumption, São Paulo, is strongly connected with four NE states: Pernambuco, Paraíba, Río Grande do Norte and Bahia, and weakly integrated with the poor state of Piauí. This is linked to the findings of dos Santos et.al. (2005), which pointed to São Paulo as a leader in the formation of the prices.

Regarding the principal producer of Rio Grande do Sul, three significant relationships are found: Rio Grande do Norte, Bahia and Ceará. Moreover, it is worthy to note that the markets of Ceará and Bahía are also connected with Santa Catarina and Paraná (in South). Likewise, Pernambuco and Paraíba are also related with the last two Southern producers with elasticities close to 0.9 (Annex 6.2, Table 6.10). The importance of the South as a main producing region in the definition of the prices is thus evident. 
Next, there are 28 pairs of relationships between NE markets, 8 are cointegrated (triangles in Figure 6.2). This means that only $29 \%$ of the relationships are cointegrated, we can therefore say that the intra-regional connection is weaker. Once again, Pernambuco has the highest number of cointegration relationships (4), but in this case also the largest elasticities (Annex 6.2, Table 6.10).

First, taking into consideration the relationships with the other domestic markets and second within the $\mathrm{NE}$, the weakest connected is the poor producing state of Piauí, which has elasticities of less than 0.5 in most of the cases.

Regarding cointegration with international prices (Category I, see methodology Section 6.4), 5 relationships with Uruguay and 8 with Argentina are analyzed. Cointegration with Uruguay does not exist while there are 5 significant relationships with Argentina. This is contrary to the expectations, as Uruguay exports a larger quantity of rice to the NE than Argentina. However, we cannot forget that Uruguay has a different system in terms of prices, by which the prices are defined in accordance with an agreement between producers and industry. Moreover, taking all Brazilian markets into consideration, Uruguay is only strongly connected with the principal producing states of Rio Grande do Sul and Santa Catarina. These two facts leads us to presume that the average export price used to determine the "Precio Convenio" has an elevated component associated with the behavior of the South prices, while it is not related to the arbitrage profits to fill the NE rice deficit.

For its part, Argentina's cointegration results are in accordance with expectations. There is integration for the higher quantity import markets: Bahia, Pernambuco and Ceará (Annex 6.2, Table 6.10). Nevertheless, Argentina's relationships (squares in Figure 6.2) show weak cointegration; with values of $\alpha$ smaller than 0.37 and $\beta$ around 0.55 , the exception being Bahia.

With regard to the speed of adjustment, Figure 6.2 evidences the slow adjustment of the NE relationships, only four cases have values above 0.5 . In order to take the lag structure of the VECM into account the Impulse Response Function is utilized. This indicates the time after a shock that each variable needs to reach the new value of the equilibrium. The results show that for around $28 \%$ of the relationships which include a NE market, prices achieve equilibrium before one year and $58 \%$ after a year and a half (Annex 6.2, Table 10).

Turning to the second part of the analysis, in Table 6.5 the results of the OLS model related to the elasticity of cointegration including all of category I are displayed (see Methodology, Section 6.4). The variable port is the most important one, where having a main port in terms of unloading is related with an increment in the elasticity of about 0.32. Distance also has a significant adjustment; however, the effect is small, with a decrease in time of 10 hours the elasticity increases by only 0.02 . In this connection, a limitation regarding measuring distance should be mentioned. Since we use distance based on the estimation provided by the Google maps, seasonal weather conditions are not accounted for, which can change travel time considerably. Even so, there is no other information source which 
included this parameter. Finally, against the expectations, GDP is not found to be significant for explaining the relationship.

Table 6. 5

Domestic Market Relationships: Effect of the Independent Variables on the Elasticity of Cointegration $(\beta)$ OLS Model

\begin{tabular}{lccc}
\hline & Coefficient & $\operatorname{Pr}(>|z|)$ & $\begin{array}{c}\text { Variance Inflation Factors } \\
\left(\mathrm{GVIF}^{\wedge}(1 /(2 * \mathrm{Df}))\right)\end{array}$ \\
Port (not) & 0.544 & 0.00 & 1.62 \\
Port (yes) & 0.869 & 0.00 & 2.14 \\
Distance & -0.002 & 0.06 & 1.25 \\
GDPx & 0.000 & 0.12 & 1.31 \\
GDPy & 0.000 & 0.74 & 0.000 \\
\hline F-statistic & 330 & P-value & 0.926 \\
Adjusted R-squared & & & Not Heterocedasticity \\
Breusch-Pagan & & & Autocorrelation \\
Durbin-Watson & & & Not Normal \\
Jarque Bera Test & & & \\
Source: Author's Elaboration. & &
\end{tabular}

Next, the OLS results for the net speed of adjustment are presented in Table 6.6. The variable port results significant, however, the velocity is almost the same between having and not having an important port. Regarding distance, although it is significant, it presents a feeble effect, which was also the result in the case of the elasticity. Once again, the last independent variable, GPD, does not have a significant impact.

Table 6.6

Domestic Market Relationships: Effect of the Independent Variables on the Speed of the Adjustment $(\alpha)$ OLS Model

\begin{tabular}{lccc}
\hline & Coefficient & $\operatorname{Pr}(>|\mathrm{z}|)$ & $\begin{array}{c}\text { Variance Inflation Factors } \\
\left(\mathrm{GVIF}^{\wedge}(1 /(2 * \mathrm{Df}))\right)\end{array}$ \\
Port (not) & 0.355 & 0.00 & 1.62 \\
Port (yes) & 0.386 & 0.00 & 2.14 \\
Distance & -0.002 & 0.01 & 1.25 \\
GDPx & 0.000 & 0.83 & 1.31 \\
GDPy & 0.000 & 0.13 & 0.000 \\
\hline F-statistic & 105 & P-value & 0.831 \\
Adjusted R-squared & & & Not Heterocedasticity \\
Breusch-Pagan & & & Autocorrelation \\
Durbin-Watson & & & Not Normal \\
Jarque Bera Test & & & \\
Source: Author's Elaboration. & &
\end{tabular}

Finally, in Table 6.7 the outcome of the cointegration with the international markets is displayed. Since only 42 observations are available for this analysis, it is necessary to interpret the results carefully. First, distance does not have a significant effect on the strength of cointegration between Brazilian and international markets. However, the estimated coefficient is negative, as expected. Next, two variables are significant: port and international market. Those markets close to a main port have a 
higher probability of being cointegrated. Together the findings of Table 6.5 and 6.7 show that access to a maritime route has a significant impact on integration. In view of the current investments aim at improving the port infrastructure, an increase in the integration of the NE states with national as well as international markets is expected. Lastly, in Table 6.7 the probabilities, while maintaining distance and GDP equal to the mean, are estimated. It can be observed that the probability of finding cointegration with Argentina is higher than with Uruguay. This could again be related to Uruguay's system of prices.

\section{Table 6. 7}

Effect of the Independent Variables on the Probability of being Cointegrated with International Markets: Probit Model

\begin{tabular}{lccc}
\hline & Coefficient & $\operatorname{Pr}(>|\mathrm{z}|)$ & $\begin{array}{c}\text { Variance Inflation Factors } \\
\left(\mathrm{GVIF}^{\wedge}\left(1 /\left(2^{*} \mathrm{Df}\right)\right)\right)\end{array}$ \\
Port (not) & 0.78 & 0.32 & 1.96 \\
Port (yes) & 1.56 & 0.05 & 3.05 \\
Distance & -0.02 & 0.30 & 1.24 \\
GDP (national market) & 0.00 & 0.52 & 1.44 \\
International Market (Uruguay) & -1.87 & 0.00 & \\
\hline
\end{tabular}

Probabilities (PIB equal to the mean and international market equal to Uruguay)

Distance $=10$ hours Distance $=30$ hours $\quad$ Distance $=50$ hours

\begin{tabular}{lccc} 
Port (not) & 0.124 & 0.069 & 0.035 \\
Port (yes) & 0.356 & 0.244 & 0.154 \\
\hline & Probabilities (PIB and Distance equal to the mean) & \\
& Uruguay & Argentina \\
Port (not) & 0.05 & 0.59 \\
Port (yes) & 0.20 & 0.85 \\
\hline
\end{tabular}

Overall significance

Wald Test (P value) $\quad 0.02$

Log ratio (restrictive model = empty model) $(\mathrm{P}$ value $) \quad 0.00$ Source: Author's Elaboration.

\subsection{Conclusions}

The northeast of Brazil is home to more than 9 million people living in extreme poverty. Rice plays a key role in the diets of many of these individuals. Hence, rice prices influence poverty and hunger in the region, and understanding rice market integration and the transmission of rice price signals is an important step for designing appropriate policies to reduce poverty and hunger. The aim this research was to determine the grade of integration of the NE with both national and international markets and examine which variables influence it.

The analysis allows for the presence of structural breaks in the cointegration relationship in response to economic changes which took place during the period of investigation. We found that the cointegration experimented structural breaks which are related to the beginning of the implantation of the Real Plan in 1994, the liberalization of the currency in 1999, and the crop failure of Rio Grande do 
Sul in 2002-2003 and the new appreciation of the currency. In addition, the Argentinean crisis of 2001 was a crucial moment in terms of integration with this country.

Furthermore, the NE states are found to be relatively isolated either from the rest of Brazil or between them. Even if the elasticity of cointegration is distributed over a wide range, there is a concentration of higher values. Some cases stand out; first, Pernambuco is the most integrated market. Although we do not have data on trade activity within Brazil, the fact that the international imports headed to the NE enter mostly through Pernambuco makes us assume that other Brazilian markets are using the port facilities of this state to export rice as well. Secondly, the most important NE producing states, Maranhão and Piaú, have almost no integration relationship, this can be explained by the fact that they are self-sufficient in rice consumption, and consequently do not depend on any other market. In addition, the principal cores of consumption (São Paulo) and production (Southern region) have an important effect on the definition of prices of the NE. Next, we found that the net speed of adjustment in the NE is slow. Even so, the Impulse Response function indicates how the NE prices achieve the equilibrium in less than a year in almost $30 \%$ of the cases.

The OLS analysis shows that the speed of adjustment is significantly and weakly affected by the variables distance in hours between the markets and the presence of a large port in the market. Nevertheless, although the latter variable is significant, the difference between having and not having a port is minimal. Concerning the elasticity of cointegration, it presents a strong positive relation with the presence of a main unloading port, while the effect of distance is negative and weak. The feeble distance effect could be associated with the estimation of the distance in hours, which does not include the effect of seasonal weather patterns. Finally, GDP is not significant in both cases.

In regards to international markets, Argentina and Uruguay are the most important suppliers of rice for Brazil. However, only Argentina is cointegrated with the NE, one possible explanation is the system of prices of Uruguay. In summary, the probit results point out how closeness to a port and the international market are significantly associated with the existence of cointegration, meaning that it is more probable to find cointegration in a relationship with Argentina and where the national market has a main port. Distance has a negative coefficient; however the effect is not significant; another approximation of the variable could increase its importance.

These results, and the recent investments in the improvement of the infrastructure, quality and efficiency of ports and roads, lead us to conclude that in upcoming periods the integration of price of the NE with both national and international markets is going to enhance. Thus, although currently the region is described as moderately isolated, this could very well change in the near future. Consequently, although the danger of a strong transmission of high increments of the NE trade partners' prices is currently small, this does not mean that it will continue invariant. Therefore, a periodical monitoring of the integration measures is recommended.

Two points remain. The normal VECM is the only one which has been applied here. However, the consideration of the Threshold Vector Error Model could have improved the results. For instance, 
cointegration might occur only when the transfer costs are lower than the gains of the trade. Nevertheless, such methodology was not applied because the inclusion of structural breaks at an unknown point, as far as we know, has not been implemented. Moreover, the concentration of breaks in three different periods could mean that for each pair of prices the cointegration could have more than one break, thus applying a methodology in which more than one unknown break is allowed for is recommended. As far as we know that is not a possibility of the Johansen approach.

\subsection{References}

Agência Nacional de Transportes Aquaviários (ANTAQ); (2009). “Anuário Estatístico Portuário - 2009”. Brazil: Brazilian Government. (http://www.antaq.gov.br/Portal/Estatisticas_Anuarios.asp. Accessed March 2011).

Agência Nacional de Transpotes Terrestes (ANTT); (Consulting March 2011). "Transporte de Cargas”. Brazil: Brazilian Government. ( http://www.antt.gov.br/carga/ferroviario/ferroviario.asp. Accessed Marck 2011).

Alemu, Z.G., \& G.R. Biacuana; (2006). "Measuring Market Integration in Mozambican Maize Markets: A Threshold Vector Error Correction Approach". paper presented at the International Association of Agricultural Economists Conference, Gold Cost. Queensland, Australia.

Asociación Cultivadores de Arroz (ACA); (Consulting June 2011). Information provided in response to a direct consultation. (http://www.aca.com.uy/).

Benson, T., S. Mugarurab, \& K. Wandac; (2008). "Impacts in Uganda of Rising Global Food Prices: The Role of Diversified Staples and Limited Price Transmission”. Agricultural Economics, 39(S1) pp 513-524.

Cazuza de Sousa, J., E. Ferreira Nobre, \& P. Bruno de Athayde; (2008). "Análise da Eficiência dos Portos da Região Nordeste do Brasil Baseada em Análise Envoltória de Dados”. Sistemas \& Gestão, 3(2) pp 74-91.

Companhia Nacional de Abastecimento (CONAB) - Santos Regina, Rice Market Analyst; (2011). "Fluxo de Importação e Exportação das Regiões Brasileiras". Information provided in response to a direct consultation. Superintendência de Gestão da Oferta (SUGOF), Gerência de Alimentos Básicos (GERAB). (www.conab.gov.br/).

Costa, C., \& M. Pasqual; (2006). "Participação e Políticas Públicas na Segurança Alimentar e Nutricional no Brasil”: Democracia y Ciudadanía en el Mercosur (319-332). LOM (Edi.). Program MERCOSUR Social y Solidário. Santiago, Chile. da Silva, A., \& G. Dalla; (2009). "O Comércio Internacional do Arroz no Contexto do Mercosul no Período de 1990-2005”. paper presented at the XLVII Congresso da Sociedade Brasileira de Economia, Administração e Sociologia Rural, Brazil.

de Oliviera Adami, A., G.S. de Camargo, \& Piedade Bacchi M. R.; (2008). "Contratos de Opção: Análise do Potecial de Sustentação de Preços Para o Mercado de Arroz". Revista Economia e Sociologia Rural, 46(1) pp 229-247.

de Sá Porto, P.C.; (2002). "MERCOSUL and Regional Development in Brazil: A Gravity Model Approach”. Revista de Estudos Econômicos, 32(1) pp 125-153.

Diário do Nordeste; (February 17th, 2011). "Movimento tem alta de 18,66\% no Mucuripe". Fortaleza, Brazil. (http://diariodonordeste.globo.com/materia.asp?codigo=935439).

Diário do Nordeste; (January 14th, 2009). "Movimentação de carga é a maior em seis anos". Fortaleza, Brazil. (http://diariodonordeste.globo.com/materia.asp?codigo=606194).

Diário do Nordeste; (May 13th, 2010). "Movimento de cargas cresce 25\%". Fortaleza, Brazil. (http://diariodonordeste.globo.com/materia.asp?codigo=784329). 
dos Santos, A, A. Baêta dos Santos, A. da Silva, A. Dionei, et al.; (2005). "Consumo, Mercado e Comercialização do Arroz no Brasil”. D. Petis, D. Lessa and E. da Rosa Freire (Ed.), Cultivo do Arroz Irrigado no Brasil. Sistemas de Produção, Embrapa Clima Temperado (ISSN

1806-9207)

(http://sistemasdeproducao.cnptia.embrapa.br/FontesHTML/Arroz/ArrozIrrigadoBrasil/cap18.htm).

Duarte, R.; (2001). "Seca, Pobreza e Políticas Públicas no Nordeste do Brasil. Pobreza, Desigualdad Social y Ciudadanía: Los Límites de las Políticas Sociales en América Latina”. Buenos Aires: CLACSO.

Dutoit, L., K. Hernández \& C. Urrutia; (2010) “Transmisión de Precios en los Mercados del Maíz y Arroz en América Latina" (Price Transmission in Latin American Maize and Rice Markets). Serie CEPAL: Desarrollo Productivo. ISBN: 97892-1-323464-8.

Escobal, J., \& A. Vásquez; (2008). "Market Integration for Agricultural Output Markets in Peru: The Role of Public Infrastructure”. Quarterly Journal of International Agriculture, 47 (1) pp 25-47.

Flaskerund, G.; (2003). “Brazil's Soybean Production and Impact”. North Dakota State University: NDSU Extension Service (Ed.).

Frankel, J., E. Stein, \& Shang-ji Wie; (1995). "Trading Blocs and the Americas: The Natural, the Unnatural and the Supernatural". Journal of Development Economics, 47(1) pp 61-95.

Fundação Dom Cabral (FDC), \& World Economic Forum; (2009). "Brazil Competitiveness Report”. Geneva: World Economic Forum.

Fundação Getúlio Vargas (FGV); (2004). “Mapa do Fim da Fome II: Miséria Nacional”. FGV, Centro de Políticas Sociasis (CPS), Da Cidadania Contra a Fome a Miséria e Pela la Vida (AÇÃO), Banco Rio de Alimentos, SESC. Río de Janeiro, Brazil (http://www.fgv.br/cps/MapaFimFomeII/inicio.htm).

Goletti, F., R. Ahmed, \& N. Farid; (1995). "Structural Determinants of Market Integration: The Case of Rice Markets in Bangladesh”. The Developing Economies, 33(2) pp 196-198.

Gonzáles-Rivera, G., \& S. Helfand; (2001). “The Extent, Pattern, and Degree of Market Integration: A Multivariate Approach for the Brazilian Rice Market”. American Journal of Agricultural Economics, 83(3) pp 576-592.

Governo Da Paraiba; (Consulted June 2011). "Programma Fome Zero". Brazil. (http://www.setras.pb.gov.br/fomezero.shtml).

Helpman, E.; (1987). "Imperfect Competition and International Trade: Evidence from 14 Countries”. Journal of the Japanese and International Economies, 1 pp 62-81.

Instituto Brasileiro de Geografia e Estatísticas (IBGE); (2006). “Censo Agropecuário, 2006”. Brazil: Brazilian Government. (http://www.ibge.gov.br/home/estatistica/economia/agropecuaria/censoagro/default.shtm).

Instituto Brasileiro de Geografia e Estatísticas (IBGE); (2008). "Mapa de Pobreza e Desigualdade, 2003”. Brazil: Brazilian Government. (http://www.ibge.gov.br/home/presidencia/noticias/noticia_visualiza.php?id_noticia=1293\&id_pagina=1).

Instituto Brasileiro de Geografia e Estatísticas (IBGE); (2010). "Pesquisa de Orçamentos Familiares 2008-2009: Avaliação Nutricional da Disponibilidade Domiciliar de Alimentos no Brasil”. Brazil: IBGE (Ed.).

Instituto Brasileiro de Geografia e Estatísticas (IBGE); (2011). “PIB Municipios 2004-2008”. Brazil: Brazilian Government. (http://www.ibge.gov.br/home/estatistica/economia/pibmunicipios/2004_2008/defaulttab.shtm).

Instituto de Pesquisa Econômica Aplicada (IPEA); (2010). "Rodovias Brasileiras: Gargalos, Investimentos, Concessões e Preocupações com o Futuro". Série Eixos do Desenvolvimiento Brasileiro, 52.

a. Instituto de Pesquisa Econômica Aplicada (IPEA); (2010). "Portos Brasileiros: Diagnóstico, Políticas e Perspectivas". Series Eixos do Desenvolvimiento Brasileiro, 48. 
International Rice Research Institute (IRRI); (2008). "Responding to the Rice Crisis: How IRRI Can Work with Its Partners". (http://beta.irri.org/solutions/index.php?option=com_content\&task=view\&id=14\&Itemid=53).

Johansen, S.; (1988). "Statistical Analysis of Cointegration Vectors". Journal of Economic Dynamics and Control, 12(2-3) pp 231-254.

Johansen, S., \& K. Juselius; (1990). "Maximum Likelihood Estimation and Inference on Cointegration with Applications to the Demand for Money". Oxford Bulletin of Economics and Statistics, 52(2) pp 169-210.

Johansen, S.; (1995). "Likelihood-based Inference in Cointegrated Vector Autoregressive Models". Oxford University Press.

Keats, S., S. Wiggins, J. Compton, \& M.Vigneri; (2010). "Food Price Transmission: Rising International Cereals Prices and Domestic Markets“. Overseas Development Institute (ODI) Project Briefings, 48.

Limão, N., \& A.J. Venables; (2001). "Infrastructure, Geographical Disadvantage, Transport Costs and Trade". The World Bank Economic Review, 15(3) pp 451-479.

Lütkepohl, H., \& P. Saikkonen; (2000). “Testing for the Cointegrating Rank of a VAR Process with Structural Shifts”. Journal of Business \& Economic Statistics, 18(4) pp 451-464

Lütkepohl, H., P. Saikkonen, \& C. Trenkler; (2004). "Testing for the Cointegrating Rank of a VAR Process with Level Shift at Unknown Time". Econometrica, 72 (2) pp 647-662

Lütkepohl, H.; (2006). "New Introduction to Multiple Time Series Analysis“. New York: Springer.

Marion, P.J., \& N. Eich Einloft; (2008). "Competitividade do Arroz Irrigado Brasileiro no Mercosul: The Competitiveness of Brazilian Irrigated Rice in Mercosul”. Rural and Agro-Industrial Organizations, 10 (1) pp 11-22.

Ministério da Agricultura (MAPA); (2005). “Agricultura Brasileira em Números - Anuário 2005”. Brazil: Brazilian Government (http://www.agricultura.gov.br/vegetal/estatisticas).

Ministério do Desenvolvimento, Indústria e Comércio Exterior (MDIC); (2011). “ALICE web Data Base”. Brasilia/DF, Brazil: Brazilian Government (http://aliceweb.desenvolvimento.gov.br/).

Ministério dos Transportes: Departamento de Portos; (2011). "Anuários Estatísticos a partir de 2001: Principais Portos Marítimos, Fluviais e Lacustres". (http://www.transportes.gov.br/).

Paz, L.S., \& A. Arinos de Mello; (2003). "Brazilian Border and Mercosul Integration Effects: An Exploratory Assessment Using the Gravity Model”. Paper presented at the 31th Brazilian Economics Meeting, Brazilian Association of Graduate Programs in Economics, Brazil.

Perobelli F., \& E. Haddad; (2003). "Brazilian Interregional Trade (1985-1996): An Exploratory Spatial Data Analysis“. ANPEC - Associação Nacional dos Centros de Pósgraduação em Economia. Series Anais do XXXI Encontro Nacional de Economia, 18.

Perobelli, F., E. Haddad, \& E.P. Domingues; (2006). "Interdependence among the Brazilian States an Input-Output Approach“. paper presented at the European Regional Science Association (ERSA) Conference. Vienna, Austria.

Pfaff, B.; (2006). “Analysis of Integrated and Cointegrated Time Series with R”. New York: Springer.

Rapsomanikis, G., D. Hallam, \& P. Conforti; (2003). "Market Integration and Price Transmission in Selected Food and Cash Crop Markets of Developing Countries: Review and Applications”. Commodity Market Review 2003-2004 (pp 51-76). Rome: Food and Agriculture Organization of the United Nations (FAO).

Sanogo, I.; (2008). "Spatial Integration of Rice Market Empirical Evidence from Mid-West and Far West Nepal and the Nepalese-Indian Border”. Asian Journal of Agriculture and Development, 4 (1) pp 139-156. 
Somik, V., \& S. Zmarak; (2003). „Location and Growth in the Brazilian Northeast“. Journal of Regional Science, 43 (4) pp 663-681.

Tinbergen J.; (1962). "Shaping the World Economy: Suggestions for an International Economic Policy". New York: The Twentieth Century Fund.

Tun-Hsiang, Y., D. Bessler, \& S. Fuller; (2006). "The Influence of Transportation Rates on Grain Prices: A Dynamic Analysis". paper presented at the Transportation Research Forum Annual Meetings. New York University.

Vinod, T.; (2006). "From Inside Brazil: Development in a Land of Contrast”. Washington, DC: The Word Bank (ISBN-10:08213-6455-3).

Wander, A. E.; (2006). “A Competitividade do Agronegócio Brasileiro de Arroz”. Custoseagronegócio (online), 2(1) pp 114.

YOU, L.; (2008). “A Tale of Two Countries Spatial and Temporal Patterns of Rice Productivity in China and Brazil”. United Nations University (UNU)- World Institute for Development Economics Research (WIDER). Research Paper, 2008/30. 


\section{Annex 6.1}

\section{Information of the Data Base}

Table 6. 8

States and Periods Included in the Investigation

\begin{tabular}{lcclcc}
\hline \multicolumn{5}{c}{ Brazil States Prices } \\
Acre & $1993 / 1$ & $2006 / 1$ & Paraná & $1993 / 1$ & $2006 / 1$ \\
Amazonas & $1993 / 1$ & $2006 / 1$ & Pernambuco & $1993 / 1$ & $2006 / 1$ \\
Bahia & $1993 / 1$ & $2006 / 1$ & Piaú & $1993 / 1$ & $1999 / 4$ \\
Ceará & $1993 / 1$ & $2006 / 1$ & Rio de Janeiro & $1993 / 1$ & $2006 / 1$ \\
Distrito Federal & $1993 / 1$ & $2006 / 1$ & Rio Grande do Norte & $1993 / 1$ & $1999 / 7$ \\
Espírito Santo & $1993 / 1$ & $2006 / 1$ & Rio Grande do Sul & $1993 / 1$ & $2006 / 1$ \\
Goiás & $1993 / 1$ & $2006 / 1$ & Rondônia & $1993 / 1$ & $2006 / 1$ \\
Maranhão & $1993 / 1$ & $2006 / 1$ & Roraima & $1993 / 1$ & $1998 / 2$ \\
Mato Grosso & $1993 / 1$ & $2006 / 1$ & Santa Catarina & $1993 / 1$ & $2004 / 5$ \\
Mato Grosso do Sul & $1993 / 1$ & $2006 / 1$ & São Paulo & $1993 / 1$ & $2006 / 1$ \\
Minas Gerais & $1993 / 1$ & $2006 / 1$ & Sergipe & $1993 / 1$ & $2000 / 10$ \\
Pará & $1993 / 1$ & $2006 / 1$ & Tocantins & $1998 / 1$ & $2006 / 1$ \\
Paraíba & $1993 / 1$ & $2006 / 1$ & & & \\
\hline \multicolumn{7}{c}{ International Prices } \\
Argentina & $1993 / 1$ & $2006 / 1$ & Uruguay & $1999 / 10$ & $2006 / 1$ \\
\hline Source: Author's Elaboration & & & &
\end{tabular}

Source: Author's Elaboration.

Figure 6. 3

International Rice Prices (US Dollars per Ton). 1993/1 - 2006/1

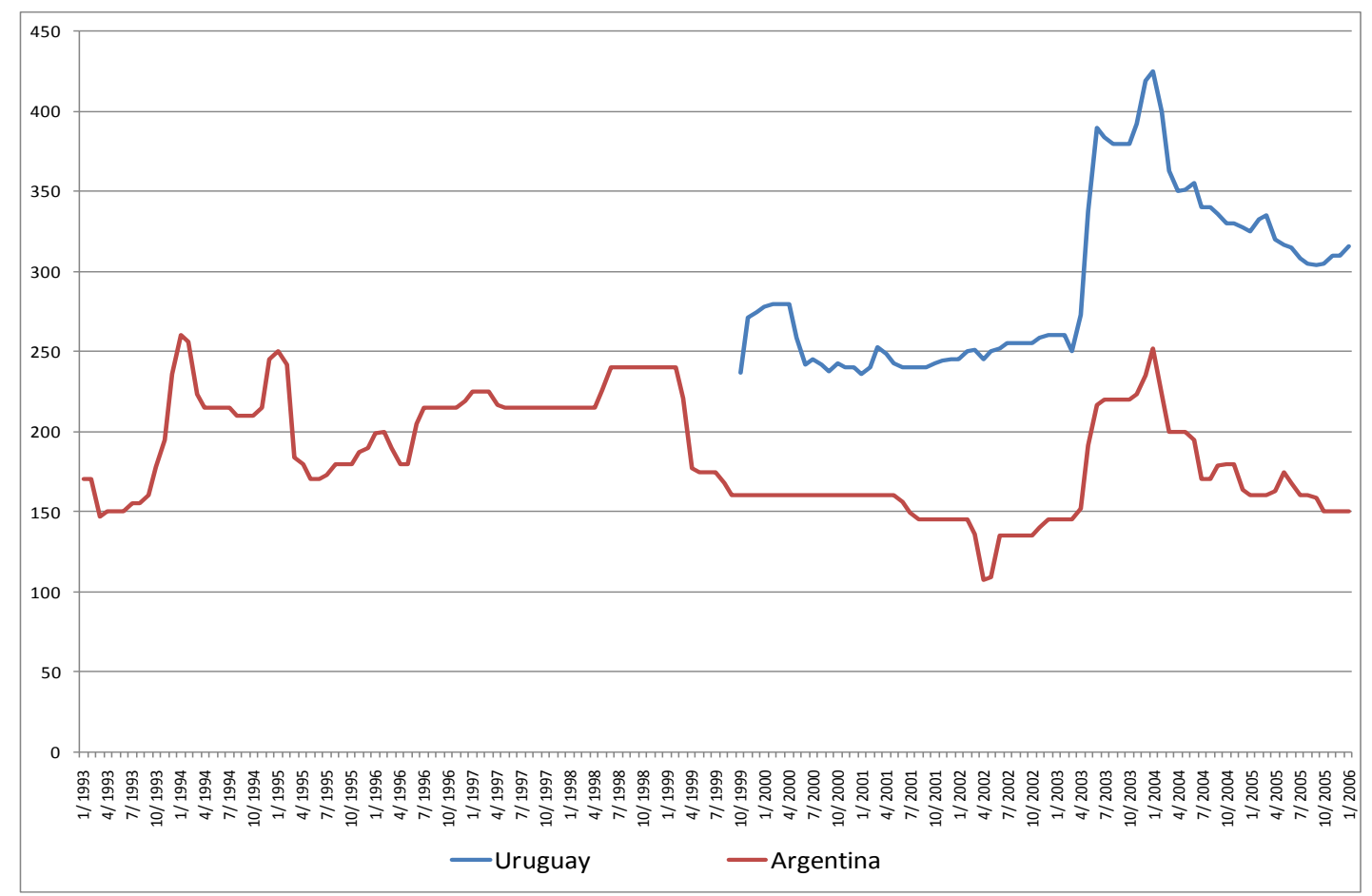

Source: Author's Elaboration. Data SAGPyA and USDA. 


\section{Annex 6.2}

\section{Results when One Structural Break is allowed for}

Table 6.9

Number of Cointegration Relationships and Year of Break Point per Market

\begin{tabular}{|c|c|c|c|c|c|c|c|c|c|c|c|c|}
\hline & & Total per Market & 1994 & 1995 & 1996 & 1998 & 1999 & 2000 & 2001 & 2002 & 2003 & 2004 \\
\hline $\mathrm{NE}$ & Pernambuco & 18 & 5 & 1 & & 1 & 4 & & 1 & 3 & 2 & 1 \\
\hline $\mathrm{NE}$ & Bahia & 16 & 2 & & 1 & 2 & & & & & 11 & \\
\hline South & Paraná & 16 & 2 & & 2 & 1 & 1 & & 3 & 4 & 3 & \\
\hline South & Santa Catarina & 16 & 3 & & & & 3 & 1 & 1 & 5 & 3 & \\
\hline SE & Rio de Janeiro & 15 & 2 & & 1 & & 1 & 5 & 1 & & 4 & 1 \\
\hline SE & São Paulo & 13 & 5 & & 1 & & & & 1 & 4 & 1 & 1 \\
\hline South & Rio Grande do Sul & 12 & 1 & & & & 2 & & 1 & 1 & 5 & 2 \\
\hline $\mathrm{NE}$ & Paraíba & 11 & 2 & 1 & 1 & 1 & & & 1 & 3 & 2 & \\
\hline MW & Mato Grosso do Sul & 11 & 2 & & & 1 & 1 & & & 2 & 3 & 2 \\
\hline SE & Espírito Santo & 11 & 1 & & & & & & & 5 & 4 & 1 \\
\hline MW & Distrito Federal & 10 & 2 & & & 1 & 2 & 2 & 1 & & 1 & 1 \\
\hline MW & Goiás & 10 & 1 & & & 1 & 2 & 1 & 1 & 2 & 2 & \\
\hline $\mathrm{NE}$ & Ceará & 9 & 1 & & & & & 1 & 2 & 2 & 1 & 2 \\
\hline MW & Mato Grosso & 9 & 1 & & & & 1 & 1 & 3 & & 2 & 1 \\
\hline $\mathrm{NE}$ & Rio Grande do Norte & 8 & 3 & & & 2 & 3 & & & & & \\
\hline SE & Minas Gerais & 8 & 1 & & & & 4 & 1 & 1 & & & 1 \\
\hline North & Pará & 8 & 4 & & & 2 & & & & 2 & & \\
\hline North & Roraima & 7 & 6 & 1 & & & & & & & & \\
\hline $\mathrm{NE}$ & Piauí & 6 & 5 & & 1 & & & & & & & \\
\hline North & Acre & 6 & & 1 & 2 & 2 & & & & & 1 & \\
\hline North & Amazonas & 6 & & & 5 & & & & & & 1 & \\
\hline North & Tocantins & 5 & & & & & & & & & 5 & \\
\hline $\mathrm{NE}$ & Sergipe & 2 & 1 & & & & 1 & & & & & \\
\hline $\mathrm{NE}$ & Maranhão & 1 & & & & & & & & & 1 & \\
\hline International & Argentina & 17 & 2 & & & & 1 & & 11 & 1 & 1 & 1 \\
\hline International & Uruguay & 3 & & & & & & & & & 3 & \\
\hline & Total per Year & & 26 & 2 & 7 & 7 & 13 & 6 & 14 & 17 & 28 & 7 \\
\hline
\end{tabular}

Source: Author's Elaboration. 
Table 6. 10

NE Cointegrated Relationships with Structural Breaks: Elasticity of Cointegration ( $\beta$ ) and Speed of Adjustment ( $\alpha)$

\begin{tabular}{|c|c|c|c|c|c|c|c|c|c|c|}
\hline \multirow[t]{2}{*}{$\begin{array}{l}\text { Type of } \\
\text { relation }\end{array}$} & \multirow[t]{2}{*}{$\mathrm{P}_{\mathrm{t}}^{\mathrm{y}}$} & \multirow[t]{2}{*}{$\mathrm{P}_{\mathrm{t}}^{\mathrm{x}}$} & \multicolumn{3}{|c|}{ Speed of Adjustment } & \multirow{2}{*}{$\begin{array}{l}\text { Elasticity }(\beta) \\
\text { (absolute } \\
\text { value) }\end{array}$} & \multicolumn{4}{|c|}{$\begin{array}{c}\text { Impulse Response Function }{ }^{\dagger} \text { : } \\
\text { Number of months after which the } \\
\text { changes in the response variable are } \\
\text { smaller than } 1 \%\end{array}$} \\
\hline & & & $\alpha_{Y}$ & $\alpha_{x}$ & $\begin{array}{c}\operatorname{Net} \alpha \\
\left(\operatorname{ABS}\left(\alpha_{\mathrm{y}}-\alpha_{\mathrm{x}}\right)\right)\end{array}$ & & $\mathrm{Y} \rightarrow \mathrm{X}^{\dagger \dagger}$ & $\mathrm{Y} \rightarrow \mathrm{Y}^{\dagger \dagger}$ & $\mathrm{X} \rightarrow \mathrm{X}^{\dagger \dagger}$ & $\mathrm{X} \rightarrow \mathrm{Y}^{\dagger \dagger}$ \\
\hline International & Argentina & Sergipe & -0.18 & -0.04 & 0.15 & 0.10 & & & 6 & \\
\hline International & Argentina & Ceará & -0.16 & 0.13 & 0.29 & 0.53 & 14 & 7 & 18 & 9 \\
\hline International & Argentina & Pernambuco & -0.12 & 0.24 & 0.37 & 0.55 & 8 & 24 & 32 & 28 \\
\hline International & Argentina & Paraíba & -0.08 & 0.22 & 0.30 & 0.57 & 8 & 6 & 18 & 22 \\
\hline International & Argentina & Bahia & -0.08 & 0.23 & 0.32 & 0.80 & 17 & 24 & 15 & 20 \\
\hline National & Tocantis & Maranhão & -0.17 & -0.08 & 0.10 & 0.03 & 24 & & 17 & \\
\hline National & Mato G.do Sul & R.G. do Norte & -0.37 & -0.33 & 0.04 & 0.04 & 19 & 33 & 12 & 34 \\
\hline National & Acre & R.G. do Norte & -0.36 & 0.18 & 0.54 & 0.05 & 24 & & 26 & \\
\hline National & Piauí & São Paulo & -0.39 & -0.40 & 0.01 & 0.07 & 9 & & & \\
\hline National & Minas Gerais & R.G. do Norte & -0.28 & -0.03 & 0.25 & 0.15 & 33 & & 12 & 30 \\
\hline National & Piauí & Goías & -0.60 & -0.35 & 0.25 & 0.19 & 33 & & 22 & 28 \\
\hline National & Piauí & Minas Gerais & -0.63 & -0.35 & 0.28 & 0.38 & & & 3 & \\
\hline National & Tocantis & Bahia & -0.28 & 0.07 & 0.35 & 0.40 & 3 & & 2 & 15 \\
\hline National & Paraíba & Roraima & -0.53 & 0.03 & 0.56 & 0.44 & 22 & & 17 & 3 \\
\hline National & Santa Catarina & R.G. do Norte & -0.20 & 0.10 & 0.30 & 0.48 & 11 & 12 & 10 & 11 \\
\hline National & D. Federal & R.G. do Norte & -0.14 & 0.21 & 0.35 & 0.57 & 8 & 17 & 7 & 16 \\
\hline National & Bahia & Santa Catarina & -0.31 & -0.14 & 0.17 & 0.68 & 20 & 28 & 22 & 16 \\
\hline National & Pará & Bahia & -0.15 & 0.10 & 0.25 & 0.68 & 19 & 10 & 15 & 11 \\
\hline National & Pernambuco & Amazonas & -0.20 & 0.03 & 0.22 & 0.68 & 30 & & 15 & 21 \\
\hline National & R.G. do Sul & R.G. do Norte & -0.12 & 0.11 & 0.23 & 0.69 & 11 & 3 & 3 & 11 \\
\hline National & Pará & Paraíba & -0.10 & 0.14 & 0.24 & 0.70 & 16 & 7 & 2 & 24 \\
\hline National & Bahia & R.G. do Sul & -0.21 & -0.04 & 0.16 & 0.70 & 28 & 34 & 7 & 9 \\
\hline National & Bahia & Paraná & -0.46 & -0.19 & 0.27 & 0.71 & 18 & 34 & 14 & 16 \\
\hline National & Minas Gerais & Pernambuco & -0.10 & 0.18 & 0.28 & 0.73 & 18 & 13 & 29 & 18 \\
\hline National & Rio de Janeiro & Ceará & -0.14 & 0.05 & 0.19 & 0.74 & 19 & 17 & 11 & 13 \\
\hline National & Bahia & Rio de Janeiro & -0.31 & -0.12 & 0.19 & 0.74 & 28 & 33 & 11 & 10 \\
\hline National & Ceará & R.G. do Sul & -0.20 & 0.08 & 0.28 & 0.77 & 24 & 15 & 16 & 6 \\
\hline National & Bahia & D. Federal & -0.24 & -0.10 & 0.15 & 0.80 & 22 & 34 & 7 & 16 \\
\hline National & Santo & Paraíba & 0.00 & 0.21 & 0.21 & 0.81 & 16 & 10 & & 10 \\
\hline National & Bahia & São Paulo & -0.29 & -0.05 & 0.24 & 0.81 & 16 & 34 & 11 & 8 \\
\hline National & Paraíba & Santa Catarina & -0.27 & -0.18 & 0.09 & 0.82 & 20 & 17 & 6 & 24 \\
\hline National & Ceará & Santa Catarina & -0.38 & 0.01 & 0.39 & 0.84 & 29 & & 3 & 23 \\
\hline National & Pernambuco & Rio de Janeiro & -0.34 & 0.05 & 0.39 & 0.85 & 18 & 20 & 4 & 11 \\
\hline National & Pernambuco & Mato Grosso & -0.30 & -0.02 & 0.27 & 0.86 & 10 & & 11 & 18 \\
\hline National & Goías & Pernambuco & -0.06 & 0.26 & 0.32 & 0.87 & 21 & 6 & 18 & 31 \\
\hline National & R.G. do Norte & Rio de Janeiro & -0.19 & 0.12 & 0.31 & 0.88 & 20 & & & 18 \\
\hline National & Ceará & Minas Gerais & -0.38 & 0.15 & 0.53 & 0.88 & 15 & & 19 & 18 \\
\hline National & Pernambuco & Santa Catarina & -0.46 & -0.10 & 0.36 & 0.88 & 8 & 18 & 15 & 19 \\
\hline National & Pernambuco & Paraná & -0.32 & 0.07 & 0.39 & 0.88 & 27 & & 20 & 13 \\
\hline National & Acre & Bahia & -0.06 & 0.30 & 0.36 & 0.88 & 10 & 6 & 26 & 33 \\
\hline
\end{tabular}

Continue... 


\begin{tabular}{|c|c|c|c|c|c|c|c|c|c|c|}
\hline National & Amazonas & Paraíba & -0.09 & 0.05 & 0.15 & 0.89 & 19 & 8 & 15 & 32 \\
\hline National & Pernambuco & Pará & -0.32 & 0.12 & 0.44 & 0.90 & 18 & 10 & 2 & 17 \\
\hline National & Bahia & Mato G.do Sul & -0.27 & -0.02 & 0.25 & 0.90 & & & 8 & 17 \\
\hline National & Ceará & Paraná & -0.10 & 0.21 & 0.31 & 0.91 & 19 & 25 & 13 & 27 \\
\hline National & São Paulo & R.G. do Norte & -0.16 & 0.13 & 0.29 & 0.91 & 14 & 11 & 17 & 18 \\
\hline National & Pernambuco & Mato G.do Sul & -0.25 & 0.01 & 0.26 & 0.91 & & 4 & 22 & 26 \\
\hline National & Bahia & Amazonas & -0.01 & 0.16 & 0.17 & 0.94 & 34 & 16 & 34 & 4 \\
\hline National & Pernambuco & Acre & -0.28 & 0.02 & 0.29 & 0.94 & 18 & & 7 & 18 \\
\hline National & Bahia & Santo & -0.41 & -0.09 & 0.31 & 0.95 & 34 & 21 & 11 & 8 \\
\hline National & Paraíba & Paraná & -0.24 & -0.02 & 0.22 & 0.95 & 36 & 2 & 12 & 18 \\
\hline National & Santo & Pernambuco & -0.10 & 0.23 & 0.33 & 0.96 & 15 & 17 & 7 & 13 \\
\hline National & Pernambuco & D. Federal & -0.38 & -0.04 & 0.33 & 0.96 & & 5 & 25 & 26 \\
\hline National & Paraíba & São Paulo & -0.22 & -0.05 & 0.18 & 0.99 & 10 & 29 & 16 & 25 \\
\hline National & Ceará & Pará & -0.04 & 0.25 & 0.29 & 0.99 & 32 & 5 & 36 & 31 \\
\hline National & Pernambuco & São Paulo & -0.30 & 0.10 & 0.40 & 1.00 & 28 & 30 & 15 & 8 \\
\hline NE Markets & Piauí & Pernambuco & -0.59 & -0.20 & 0.39 & 0.41 & & 7 & & \\
\hline NE Markets & Piauí & Sergipe & -0.54 & -0.02 & 0.52 & 0.55 & & & 13 & \\
\hline NE Markets & Piauí & Paraíba & -0.15 & 0.25 & 0.41 & 0.65 & 8 & & & 31 \\
\hline NE Markets & Bahia & Paraíba & -0.27 & 0.03 & 0.30 & 0.80 & 16 & 33 & 24 & 13 \\
\hline NE Markets & Bahia & Ceará & -0.32 & -0.12 & 0.20 & 0.83 & 28 & 27 & 12 & 10 \\
\hline NE Markets & Bahia & Pernambuco & -0.28 & -0.03 & 0.26 & 0.84 & 10 & & 12 & 17 \\
\hline NE Markets & Pernambuco & Paraíba & 0.14 & 0.26 & 0.11 & 0.97 & 24 & 5 & 22 & 20 \\
\hline NE Markets & Ceará & Pernambuco & 0.00 & 0.40 & 0.41 & 0.98 & 21 & 5 & 25 & 4 \\
\hline \multicolumn{3}{|l|}{ Average } & -0.24 & 0.04 & 0.28 & 0.70 & 19 & 17 & 15 & 18 \\
\hline \multicolumn{3}{|l|}{ Maximum } & 0.14 & 0.40 & 0.56 & 1.00 & 36 & 34 & 36 & 34 \\
\hline \multicolumn{3}{|l|}{ Minimum } & -0.63 & -0.40 & 0.01 & 0.03 & 3 & 2 & 2 & 3 \\
\hline
\end{tabular}

The empty space means that the value is higher than 36 months.

$\dagger \dagger$ The highlighted value corresponds to the response of the NE market to a shock in the other market.

Source: Author's Elaboration 